University of Rhode Island

DigitalCommons@URI

Open Access Dissertations

2018

\title{
Climate Change and Coastal Cultural Heritage: Insights from Three National Parks
}

\author{
Alanna Casey \\ University of Rhode Island, alannacasey@my.uri.edu
}

Follow this and additional works at: https://digitalcommons.uri.edu/oa_diss

\section{Recommended Citation}

Casey, Alanna, "Climate Change and Coastal Cultural Heritage: Insights from Three National Parks" (2018). Open Access Dissertations. Paper 745.

https://digitalcommons.uri.edu/oa_diss/745

This Dissertation is brought to you for free and open access by DigitalCommons@URI. It has been accepted for inclusion in Open Access Dissertations by an authorized administrator of DigitalCommons@URI. For more information, please contact digitalcommons-group@uri.edu. 
CLIMATE CHANGE AND COASTAL CULTURAL

HERITAGE: INSIGHTS FROM THREE NATIONAL PARKS

BY

\begin{abstract}
ALANNA CASEY
A DISSERTATION SUBMITTED IN PARTIAL FULFILLMENT OF THE

REQUIREMENTS FOR THE DEGREE OF

DOCTOR OF PHILOSOPHY

IN

MARINE AFFAIRS
\end{abstract}

UNIVERSITY OF RHODE ISLAND

2018 
DOCTOR OF PHILOSOPHY DISSERTATION

OF

ALANNA CASEY

\section{APPROVED:}

Dissertation Committee:

$\begin{array}{ll}\text { Major Professor } & \text { Austin Becker } \\ & \text { John Jensen } \\ & \text { Jessica Frazier }\end{array}$

Nasser H. Zawia

DEAN OF THE GRADUATE SCHOOL

UNIVERSITY OF RHODE ISLAND

2018 


\begin{abstract}
Global climate change is expected to contribute to between 30 and 122 centimeters of sea-level rise by 2100 , as well as increase the frequency and intensity storm surge, flooding, and erosion in coastal systems (IPCC 2014; Melillo, Richmond and Yohe 2014; Moser, Williams and Boesch 2012). Consequently, coastal cultural resources including archaeological sites, historic structures, and cultural landscapes will face increasing damages from salt water inundation, storm erosion, that comprise the frequency and intensity of the negative impacts of these coastal climate changes on cultural heritage resources, sites, and landscapes will also increase (Daly 2011b; WHC 2006; Cassar 2005). Current research on the climate change impacts on coastal heritage takes an ahistorical perspective, examining how these resources will be impacted by climate change moving forward. However, cultural resources hold both modern values and represent past uses of coastal landscapes. This research employs a historical perspective, examining long term relationship between people and climate or environment in a specific location, how past responses to environmental change, alteration of the environment, and other decision-making continue to affect current practices (Adamson, Hannaford, and Rohland 2018).

By examining three case studies in the central Gulf Coast of Florida and Mississippi, Tidewater Virginia, and the northeastern waterfront of San Francisco, California, this research explores how federal managers' have perceived, created, and responded to environmental change from early European settlement through the present. Based on 20 key informant interviews as well as extensive archival and document research with 29 collections at 6 institutions, this research changes in the
\end{abstract}


reciprocal relationship between the built and natural environment overtime. This study employed qualitative content analysis and document coding (Creswell 2014; Greene, Caracelli, and Graham 1989). As current managers address climate change, this historical perspective explores how local environmental relationships, traces key themes of landscape change and management responses through the American period of each site.

Since the early period of American management, modification and environmental engineering, rather than retreat, has been the dominant response to coastal erosion, storm surge, flooding, and sea level rise. Overtime, federal manager's metrics of coastal threat and risk have changed as the use of the sites has transitioned. At each of the three sites, local climate patterns and responses that developed overtime continue to manifest in the environmental perceptions and decisions made by managers. And while the patterns at each site are location specific, the challenges faced by managers at Pensacola and the Mississippi Barrier Islands, San Francisco, and the Virginia Peninsula may have applications for transitional military, urban, and commemorative landscapes adapting to climate change, respectively. 


\section{ACKNOWLEDGMENTS}

Thank you to my major professor, Dr. Austin Becker for the guidance on this project and the graduate school process. Thank you to Dr. John Jensen for the mentorship and guidance on this project, willingness to read early drafts, and for challenging me with insightful questions. Thank you to Dr. Rod Mather for the thought-provoking conversations, guidance, opportunities, and connections over the past six years. Thank you to Dr. Jessica Frazier for the guidance on both this project and for sharing the process of developing historical research questions. Thank you to Dr. Amanda Babson for the expertise and insight into the National Park Service. I am indebted to my entire committee for providing extensive feedback on each chapter throughout this process.

Thank you to the many professionals who participated in this research for the time, insight, and willingness to share. This research was made possible by monetary and/or scholarly support from the URI Center for the Humanities, Coastal Resources Center, Department of Marine Affairs, Department of History, and Applied History Lab, as well as the administrative expertise of Judy Palmer, Denise Foley, Nancy Woyak, and Ben Morris.

Thank you to my dear friends and colleagues Kristen and Anna, for the encouragement, criticism, comments, frankness, and friendship which are helping me to discover and refine my voice as a researcher. To my friends and colleagues Kristine, Clara, and Talya for listening, advising, and encouraging. To my colleagues in the Marine Affairs and History departments for reading drafts, editing emails, watching practice presentations, and being friends: Katie, Yating, Mary, Joey, Eric, 
Sarina, Melvin, Peter, Duncan, Lena, Morgan, and Emma. To my far-away friends: Jenny, Sarah, Jason, Mike, Mike, Raj, Anna, Laura, Mike, Sam, and Esme, for the skillful copyediting, unwavering support, and boisterous breaks. Finally, to my entire family, especially my parents Tracey and Vince, my partner Justin, and my brother McCullough, for everything.

I am indebted to everyone listed above and many, many others for your generosity, patience, kindness, and guidance. I will strive to reflect your efforts throughout my career and life. 


\section{TABLE OF CONTENTS}

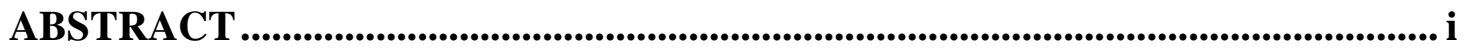

ACKNOWLEDGMENTS .................................................................................... iv

LIST OF TABLES ............................................................................................. vii

LIST OF FIGURES ................................................................................................................... viii

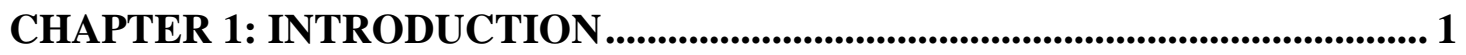

CHAPTER 2: INSTITUTIONAL AND CONCEPTUAL BARRIERS TO CLIMATE CHANGE ADAPTATION FOR CULTURAL RESOURCES.... 27

CHAPTER 3: "KEEPING AMERICANS, 'AMERICAN':" NATURAL AND CULTURAL EROSION AND THE SHAPING OF COMMEMORATIVE LANDSCAPES IN TIDEWATER VIRGINIA

CHAPTER 4: FROM MILITARY FORTRESS TO RECREATIONAL HAVEN: FEDERAL MANAGERS' EXPECTATIONS OF PERMANENCE ON SHIFTING SANDS IN PENSACOLA AND THE MISSISSIPPI BARRIER ISLANDS 96

CHAPTER 5: "PRESENT, AVAILABLE, OR WHICH CAN BE ACQUIRED BY GRADING AND FILLING:" LEAVING SPACE FOR THE BAY ALONG SAN FRANCISCO'S CONSTRUCTED SHORELINE ................... 138

CHAPTER 6: FROM RESOURCE- TO PROCESS-BASED MANAGEMENT: LOCAL MANIFESTATIONS OF NATIONAL CULTURAL RESOURCE MANAGEMENT PRIORITIES IN THREE COASTAL NATIONAL PARKS

CHAPTER 7: CONCLUSION.............................................................................. 225

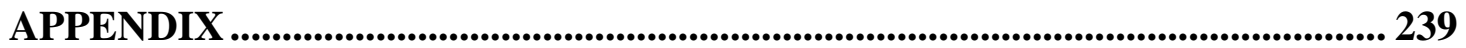

REFERENCES ........................................................................................................................... 241 


\section{LIST OF TABLES}

TABLE

PAGE

Table 1. Archives Visited and Collections Referenced ............................................ 23

Table 2. Case Study Site Selection Criteria ......................................................... 32

Table 3. Results of Interview Coding: Conceptual and Institutional Barriers to Cultural

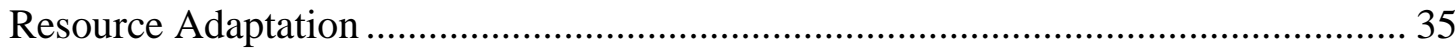

Table 4. Barriers and Opportunities for Cultural Resource Climate Change Adaptation 48

Table 5. Case study sites and selection criteria................................................... 185

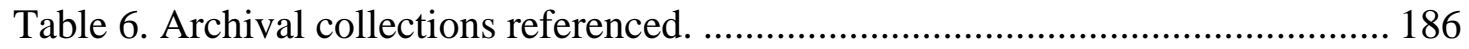

Table 7. key informant interview formats and locations.................................... 188

Table 8. illustrates the management goals, ideas of permanence, rationales for creating change and responses to change in Jamestown-Yorktown area from 1894 through the

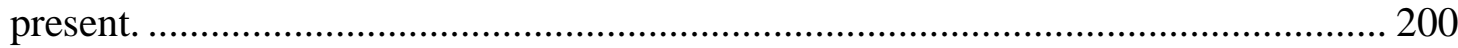

Table 9. management goals, ideas of permanence, rationales for creating change and responses to change in Pensacola and the Mississippi Barrier Islands overtime....... 210

Table 10. Management goals, expectations of permanence, rationale for creating change, and response to environmental change overtime in San Francisco's North Beach and Aquatic Park Area.

Table 11. framework of the transition of management priorities overtime from resource-, use- and process-based resource management. 


\section{LIST OF FIGURES}

FIGURE

PAGE

Figure 1. John Smith's 1606 map of Virginia. 55

Figure 2. Official seal of the Jamestown Exposition of 1907 (left) and a modern fleet entering Hampton Roads during the exposition (right). 67

Figure 3. shoreline of Colonial National Monument both before (left) and after (right) CCC crews graded the area.................................................................................... 78

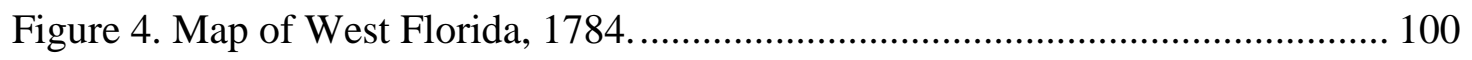

Figure 5. Map of Pensacola Bay, including the Pensacola Naval Yard, 1860-1869. 108

Figure 6. Ruins of Fort McRee, on Perdido Key, 1906............................................ 111

Figure 7. Climate Change Wayside Panel from Gulf Islands National Seashore...... 132

Figure 8. Map of San Francisco in 1851 showing the original shoreline and the watercovered lots sold by city officials.

Figure 9. Panama-Pacific International Exposition poster symbolizing the rebuilding San Francisco after the 1906 earthquake. 161

Figure 10. Colonial National Historical Park............................................................. 191

Figure 11. Gulf Islands National Seashore. …………………………................... 203

Figure 12. San Francisco Maritime National Historical Park Map............................ 212 


\section{CHAPTER 1: INTRODUCTION}

Along the coast, change comes in many forms. It happens gradually as tides roll in and out or suddenly as storms erode shorelines. Change may happen seasonally as winter storms build steep berms along the beach or on geologic time scales. However, these natural processes are not the only causes of coastal change. People have been using and modifying the coastal environment to suit their perceptions of the space, for the span of human history. The coastal environment is distinct from inland locations because the multiplicity of human uses, the intersection of cultures, and the volatile weather and environment (Westerdahl 1992). The water-land boundary along coastlines has long been subject to human modification, both to create additional coastal land through infill, to shape existing shorelines into more productive formations, and to protect valuable coastal land from disappearing through inundation and erosion (Goudie 2013; Charlier, Chaineux, and Morcos 2005; Rippon 2000). Today, coastal spaces retain unique environmental, social, industrial, and other features that create and support human livelihoods (McGranahan, Balk, and Anderson 2007). And approximately $27 \%$ of the global population resides within 100 kilometers of the coast, at an elevation lower than 100 meters (Kummu et al. 2016).

Both public policies and technological developments have contributed to patterns of human-induced change in coastal spaces. For instance, in the United States, the Rivers and Harbors Act of 1899 and subsequent legislation encouraged the modification of waterways for commercial purposes, which led to the containerization of ports and shipping, thereby changing the space requirements and use patterns of coastal ports. As a result of the industrial revolution, technological advancements, and 
population expansion, the human-induced production of greenhouse gases is increasing average global temperatures, causing changes in precipitation patterns, biological seasons, and other alterations. Along the coastline, anthropogenic climate change is causing sea level rise, which is linked to increased coastal inundation, flooding, erosion, and the loss of coastal land (Wong et al. 2014). The coastal environment is volatile and these places have historically experienced climate volatility; however, anthropogenic climate change represents a rapid and unprecedented alteration of climatic conditions (Wong et al. 2014). Over the $20^{\text {th }}$ century, global sea levels rose approximately 0.14 meters (Kopp et al. 2016). By 2100, climate scientists anticipate that global sea level will rise between 0.3 and 1.2 meters (Mellilo, Richmond, and Yohe 2014). In addition to projected sea level rise and accompanying erosion and flooding, localized projections of increased hurricane activity will affect modern human uses along the shoreline, including the historical coastal landscapes (Moser, Williams, and Boesch 2012). This research will focus on coastal climate changes associated with sea level rise, storm surge, coastal flooding, and coastal erosion.

Along the coastline, tangible and intangible artifacts, including traditions, stories, commemorative monuments, documents, buildings, and landscapes preserve a record of past human uses. These features are collectively known as "cultural heritage" (Ashworth and Larkham 2013; Vecco 2010; Blake 2000). The tangible remains of cultural heritage including historical structures, archaeological sites, and cultural landscapes are "cultural resources." People value cultural resources for their potential to contribute to the academic study of the past, as well as for the cultural, 
spiritual, and personal enjoyment they provide, and the tourism and economic value they generate (Claesson 2011). And people seek to preserve these resources for the value they provide for present and future generations. As both a valuable resource themselves, and a record of human use and manipulation of the coastline overtime, cultural resources are uniquely situated to serve as a focal point of a critical examination of the human dimensions of 'change' in coastal climate change.

Historical sites and structures are records of human use, interpretive aids for the history of human and environmental interactions along the coastline, and important resources in and of themselves. Cultural resources are evidence of past environmental management practices in the coastal area (Whitney 1996). The study of these resources offers instructive lessons on the successes and failures of past management (Jarvis 2016; Rockman et al. 2016; Erlandson 2012; Gillis 2012). The importance of protecting cultural resources (Claesson 2011; A. J. McIntosh and Prentice 1999) and the idea that these resources are evidence of past social and management adaptations to environmental change (Rockman et al. 2016; Jarvis 2016) are both well-represented in the literature. But scholars have separated the history of change embodied and represented by cultural resources from the process of changing taking place today with the changing climate (Carey et al. 2014).

This research takes a temporally broad and methodologically-diverse perspective, first asking what barriers exist that prevent managers from developing and utilizing adaptation strategies for cultural resources for climate change impacts. This research then examines how federal and state managers in the U.S. have created and responded to change in the coastal environment from the period of early European 
settlement in the modern United States through the present. Finally, this research asks how these national and local priorities have manifest in the coastal historical built environment. This research addresses the questions:

1. What unique barriers exist today that prevent the adaptation of cultural resources for projected climate change impacts?

2. How have federal manager's perceived, responded to and created change in three coastal spaces from the period of early European settlement through current management of climate change?

3. How have American national and local priorities manifested and interacted in the management of the coastal historical built environment overtime?

By coupling a historical approach with key informant interviews, this research explores both current climate change barriers for cultural resource adaptation and the historical roots of frameworks, understandings, and responses to change in the area. This extended temporal perspective allows a long-term look at how federal and state managers have addressed and created change in coastal spaces by examining the interplay between the built and natural environment in three coastal national parks.

The National Park Service (NPS) preserves and interprets the most extensive collection of cultural resources in the United States. Founded in 1916, NPS was established by Congress to "conserve the scenery and the natural and historical objects and the wild life therein and to provide for the enjoyment of the same in such manner and by such means as will leave them unimpaired for the enjoyment of future generations" (United States Congress 1916). The projected impacts of coastal climate change on the cultural resources and education programs of NPS are beginning to challenge managers' existing goals, priorities, and techniques of resources preservation (Beavers, Babson, and Schupp 2016). 
This research focuses on three coastal case study sites within NPS to compare how the distinct local environments, contexts, and histories of these sites manifest in the responses to and creation of coastal built and environmental change overtime. This outcome is relevant for the current and ongoing management of coastal cultural resources, but also contributes to a broader historical understanding of climate adaptation in the coastal environment overtime. The following section outlines the current disciplinary contributions to the historical study of climate change responses and climate change adaptation specific to cultural resources. The remaining four sections in this chapter outline the work in the social science, risk-perception and planning, current NPS, and historical approaches to climate change, and discuss how each approach informs climate change adaptation for cultural resources.

\section{Historical Approaches to Climate and Human Interactions in the Social Sciences}

Climate is changing and this change is occurring alongside management, social, environmental, industrial, technological, and cultural change. Existing environmental perceptions, management patterns, and social priorities influence the climate change management and adaptation planning along the coastlines of the United States (Fussel 2007). Research on the human dimensions of climate change is taking place in academic, governmental, organizational, and private settings, and making use of various disciplinary and pragmatic approaches (Fatoric and Seekamp 2017). These varying approaches to climate change often differ in their temporal scale and point of focus (Adamson, Hannaford, and Rohland 2018). As such, numerous scholars in the social sciences and humanities have called for these fields to take a 
larger role in framing and identifying climate change challenges (Hulme 2011), suggesting that these fields of study can illuminate the social, cultural, and ethical relationship between people and the environment (Bird 1987; Palsson et al. 2013), clarify and challenge assumptions about historical climate data and the declension narrative (Carey et al. 2014), examine how environmental risks are perceived (Hulme 2008), and investigate how environmental decisions are made (Roncoli, Crane, and Orlove 2009). These questions are addressed across and between disciplines.

\section{Geography, the Environment, and the Shaping of Culture}

Geographers include cultural resources in their studies of the longstanding interaction between people, the environment, cultural change and movement, linking past environmental change with cultural customs, migrations, or other events. During the late $19^{\text {th }}$ century, geographers developed the theory of environmental determinism, which speculated that the natural climate and context provided limits to and informed the range of cultural development that could take place in a given setting (Peterson and Broad 2009; Coombes and Barber 2005; Meggers 1954). This theory was extended and used to justify imperialism and racist ideas, such as Social Darwinism. Starting in the early $20^{\text {th }}$ century, the theory of historical possibilism, first introduced by Boas argued that regional climate and environment were amongst many explanatory factors in the development of culture (Peterson and Broad 2009).

In addition to the environment as an explanatory factor in culture, geographers have explored the idea that cultural world views, sometimes expressed through religion, may shape perceptions of the environment and the environment itself 
(Glacken 1967). For instance, Christianity placed humans in an exalted position over the wild, framing how man was to interact with nature. The construction of churches directly impacted the natural world through the removal of stone and other materials (Glacken 1967). The first wide-scale changes to Earth, on a global scale, were wrought at least 2.6 million years ago with hunting and gathering and, in many cases, may be impossible to separate human from natural change (Goudie 2013). Other geographers have focused directly on climate change adaptation practices. However, the importance of place and heritage are often underrepresented in climate change adaptation planning (Adger et al. 2012). By examining concepts of climate, change, and adaptation on a broad scale, geographical work on climate change situates modern climate change in a long-term pattern of human effects on the natural environment.

\section{Lessons on Climate Fluctuation and Cultural Adaptation from the Deep Past}

Many environmental anthropologists and archaeologists studying climate change have examined the changing relationships between people and nature shown through symbolism and stories that explain environmental conditions, and how people generate ecological knowledge, among other ideas. Broader theories employed by geographers and others on responses to climate and weather in the historical past, as well as data on the impacts of these weather patterns, come from archaeological studies of prehistorical and historical sites. Archaeological work on past environmental fluctuation has focused on social collapse in prehistorical societies and change with colonization or imperial presence, with some studies linking these past conditions to more recent evidence of the social impacts of environmental change. 
Archaeologists, have studied cultural collapse in past societies related to historical periods of climate fluctuation or human-induced climate change (Diamond 2011; Hunt and Lipo 2011; Orlove 2005; Demonocal 2001; Wigley, Ingram, and Farmer 1981). They have correlated many periods of climatic change with cultural dislocations, collapses, and population declines (Coombes and Barber 2005). The collapse of the Akkadian, Mayan, Mochican, Tiwanaku and other empires can be directly linked to periods of persistent drought; however, these cultures were able to reduce social complexity, shift to different subsistence levels or different locations, and reorganize supply systems in order to adapt to climate changes (Demonocal 2001). Along the Atlantic and Gulf coasts of the southern United States, during periods of sea level regression, societies adjusted their occupation to be more sedentary and their construction to be more modest. Past adaptation to climate fluctuations suggest that social change is possible, but not universally successful and requires social adjustment (Thompson and Worth 2011). Anthropologist Ben Orlove (2005) hypothesizes that the impact of climate fluctuations on different societies may be dependent on how tolerant each society is of environmental manipulation. It may be difficult to distinguish between social adaptation to climate alone and social adaptation to a combination of climate and cultural stressors (Orlove 2005).

\section{Traditional Ecological Knowledge and the Modern Interpretation of Climate}

Another anthropological approach to understanding cultural interactions with climate change focuses on traditional ecological knowledge, studying how people view, interpret and symbolize changes in the environment and weather (Crate 2011; 
Mergen 2008). Anthropologists examining the cultural interpretation and presentation of weather and climate in the present often focus on indigenous communities living in the Arctic and Oceania, that will be disproportionately affected by climate change (Roncoli, Crane, and Orlove 2009). Climate fluctuations and changes alter the timing, and potentially threaten the value of cultural practices such as baling hay when longer or wetter rainy seasons will cause bales to mold (Crate 2011, 2008). In addition to changes in the seasonality of hay gathering and harvest, the cultural interpretation of seasons through stories, folklore, and tradition may also change (Crate 2008).

Environmental learning is a key part of the process for emigrants to adapt to a new environment and becoming fluent in and familiar with the climate, floral, faunal, topographical, cultural, or other features of a new location may take over a generation, or around 35 years (Rockman 2003). With this argument, if the climate is changing, even if people are not moving, they may be less able to predict or understand the weather and environmental patterns around them.

Additionally, anthropologists have engaged with questions of modern social responses to climate change by examining how the problem is presented and understood by society. Anthropologists have critiqued the presentation of climate change data, arguing that describing weather patterns only through degrees of temperature, percentage humidity, and centimeters of rainfall, removes or deemphasizes the sensory experience of weather as an experience (Hulme 2008). Climate is both a cultural construct and an experiential one. Understanding attitudes may be key to motivating climate change action, as people attempting to enact change were most successful when the information they provided confirmed or utilized, rather 
than clashed with existing beliefs and social structures (Chess and Johnson 2007). In addition to illuminating how cultures understand and symbolize change in the environment, understanding the social interpretation of climate, environment, and change may be vital to understanding adaptation options. Climate fluctuations may change weather patterns, growing seasons, appropriate construction materials, or a number of other factors, changing the sensory experience of living in a particular environment. This information may in turn be valuable in identifying how communities construct climate problems and therefore, determining solutions that are culturally acceptable and appropriate (Crate 2011).

\section{Risk Perception, Policy, and Planning}

Change becomes risk if the resulting condition is perceived as problematic (Moses and Rosenhaft 2015). What society considers an environmental or climate risk depends on both experiential factors such has personal experience with the hazard and demographic factors, including age, gender, and social network. However, there is little consensus in the risk perception literature on which of these factors are most influential in determining environmental risk perception (Dake 1992; Jasanoff 1987). People do not perceive risks quantitatively, but through a mixed of information and experience (Luhmann 2008). The perception of risk is influenced by complex social, political, and cultural processes including personal observation, perceptions of one's social network, ability to take action, and level of trust in institutions (Bickerstaff 2004). While some studies found demographic variables to be important, others found that experience with environmental hazards is more influential on risk perceptions 
(Carlton and Jacobson 2013; Raymond and Brown 2011). Personal experience with hazardous weather scenarios affected individuals risk perceptions; however, simply living in a high-risk area did not (Lujala, Lein, and Rod 2015). However, risk perception does not necessarily corelate with preparation or action. People who have had personal experience with a hazardous weather condition such as a hurricane may be less likely to act to reduce their risk because they have survived the situation before (Peacock, Brody, and Highfield 2005). In addition to the influence of demographic and experiential factors, the context or cause of the hazard may influence how people perceive risk. The perception of the hazard as natural, quasi-natural, or technological may affect how active people are in responding, planning or managing for the hazard. Risks from technological hazards may be seen as avoidable, and therefore, less risky, than threats derived from natural hazards including climate and weather (Bostrom and Lashof 2007; Axelrod, Mcdaniels, and Slovic 1999). This suggests that managers may respond differently if they perceive environmental change to be related to climate change rather than as an expected, seasonal range of environmental volatility.

Perceptions of risk frame and define the problems that may be addressed through public policies and actions (Moses and Rosenhaft 2015). Therefore, the various demographic and contextual factors affect how people perceive risks may also contribute to the framing of problems, policies, and solutions. However, additional factors are at play in problem definition. Not all voices carry equal weight in the process of public problem definition. Individuals, agencies, and organizations can influence how public problems are defined (Flader 1998) and the way in which a problem is framed can limit or control the decision-making and possible outcomes (de 
Boer, Wardekker, and van der Sluijs 2010; Nisbet 2009; Miller 2000; Rochefort and Cobb 1993). Disciplinary background and discrepancies in professional training and goals of those addressing the problem may affect the way in which they assessed the agenda setting occurs, priorities are established, and levels of acceptable risk are assessed (Tarr and Jacobson 1987). The situation or outcome to which people assign risk can affect the way they design solutions (Tarr and Jacobson 1987).

Cultural resources are valuable to the tourists, planners, managers, and conservators who use the sites, structures, and artifacts as they are, as well as the social scientists and humanists who study the broader patterns of social, cultural, and human activity represented by these resources. Many academic disciplines approach and study historical and ongoing cultural patterns of interacting with and modifying the environment. Each scholar frames the climate change risk as well as the story of change represented by these resources in ways that reflect their disciplinary training and the existing literature in the field.

\section{Cultural Resources and Climate Change: The Current NPS Approach}

In the United States, cultural resources that have retained integrity, as defined by the condition of the site, and significance, as defined by the connection of the site to important people, events, and patterns in the historical past are eligible for legal protection under the National Historic Preservation Act (King 2004). While fishermen can update their vessels or port managers can relocate infrastructure away from the shoreline, part of the value of cultural resources may reside in the maintenance of a site or structure in its original position or with its original materials (Lowenthal 2015). 
This may limit or alter the options for site and structure maintenance. The material conditions and preservation of archaeological artifacts and sites, historical structures, and cultural landscapes are continuously challenged by time, looting, erosion, development, weathering, and war (Erlandson 2012; Demonocal 2001). And while cultural resources have changed overtime both from intentional updates and unintentional damages, today, managers work to maintain resources to a fixed condition or time period.

Historic preservationists, archaeologists, and cultural resource managers expect climate change to lead to the erosion, submersion, storm damage, or inundation of coastal archaeological sites, historical structures, and cultural landscapes (Morgan et al. 2016; Daire et al. 2012; Sabbioni, Brimblecombe, and Cassar 2010; Fitzpatrick, Kappers, and Kaye 2006). Archaeological materials that are not completely submerged may be damaged or destroyed by salt water intrusion, increased wave or wind action, alterations of the range of biodeteriogens, or the direct force impacts of storm surge (Schupp, Beavers, and Caffrey 2015; Sabbioni, Brimblecombe, and Cassar 2010). In addition to these direct impacts from climate change, increasing climate issues may highlight or exacerbate existing structural weaknesses or site problems rather than creating new issues (Cassar 2005). Cultural landscapes may be altered by a shift in the boundary between water and land, affecting the shape of the coastline and the condition or diversity of affiliated species. The force of storm surge may directly destroy artifacts, sites, and structures. Increased coastal and nuisance flooding, including a rise in the water table or salt water intrusion may change species assemblages, destroy buried archaeological sites, or affect the traditional uses of land, 
coastline, and space. And increased coastal erosion may directly compromise cultural resources or expose unknown or undocumented sites to increased risk of destruction or looting. The potential changes to cultural resources resulting from projected climate change may change both the physical condition of archaeological sites, historic structures, cultural landscapes, and museum collections, as well as the uses of these spaces by traditional and local communities and park visitors.

NPS frames risks to cultural resources from climate change as additional or more variable damage than existing weather and climate risk factors (Morgan et al. 2016). Sea level rise, storm surge, coastal flooding, and increased coastal erosion may alter the condition of, access to, or use of the tangible remains of the past, for descendant communities, tourists, researchers, and the National Park Service. Sea level rise may cause the loss of sites through submersion, loss of access to traditional and culturally important sites, and the dislocation of traditional knowledge associated with existing coastal sites, such as local knowledge of the timing of fishing runs being rendered inaccurate due to climate change (Adger et al. 2012; Lazrus 2012).

NPS frames the response to climate change as a planning challenge (NPS $2015,2013,2012,2010)$. If managers can predict the impacts of climate change, planners and others can focus limited financial, personnel, and engineering resources to protect the sites and spaces deemed most valuable, while documenting other sites that may be allowed to succumb to weathering and erosion. Rooted in the natural hazards and food security literature of the 1970s and 1980s and popularized by the Environmental Protection Agency, vulnerability or risk assessment procedures gather information on the projected climate conditions, as well as the projected exposure of a 
resource to these conditions and the likely result of this exposure on the materials that comprise the resource to determine a relative vulnerability of different sites, artifacts, and landscape components to environmental hazards (Bassett and Fogelman 2013). In light of climate change, NPS recommends this information gathering approach to climate change risks for natural and cultural resources (Glick, Stein, and Edelson 2011). Various projects within NPS are working to assess how cultural resources will be impacted by climate change and which resources will be affected, in order to use this information to make plans to protect, remove, interpret, or ignore the impacts of climate change on cultural resources in the future (Rockman et al. 2016; Beavers, Babson, and Schupp 2016).

In response to climate change risks to cultural resources, archaeologists recommend different methods of resource prioritization and preservation. NPS documents assert that the loss of sites may be unavoidable or necessary, but do not prescribe a methodology for prioritization across the parks, instead suggesting that decisions about the protection of sites will take place at the park-level (Rockman et al. 2016). Cultural resources need to be evaluated and considered in the context of the local or broader community in order to determine both the value, and relative risk to these resources from climate change (Tengberg et al. 2012). One method of prioritization would be the "rational prioritization" of protecting the oldest known sites first (Erlandson 2012), consistent with traditional disciplinary procedures, the oldest known site may not always be the rarest or most at risk from inundation or coastal erosion. 


\section{Applying Historical Perspectives to Modern Climate Change: Methodological}

\section{Approach}

Research that takes a historical perspective can illuminate the long-term relationship between people and climate or environment in a specific location, can uncover path dependencies to explain how past decisions continue to constrain current practices, and can examine the groups participating in climate change adaptation to understand if and how current practices are perpetuating historical power imbalances (Adamson, Hannaford, and Rohland 2018). Influential climate change thinker and historian Dipesh Chakrabarty $(2012,2009)$ argues that climate change represents a divergence from historical climate conditions as well as historical climate perceptions because climate change shows that humans have themselves become one of the geologic forces and factors to which cultures and societies must adjust. While societies

have historically responded to both environmental volatility and man-made changes to the environment on a local and regional scale, societies must now respond to natural and manmade environmental change on a global scale as well (Palsson et al. 2013; Chakrabarty 2009). However, even if climate change represents a departure from the paradigm of a give and take between humans and the environment to a multidirectional feedback human and environmental alteration, cultural perceptions of environment, manipulation of environment, and responses to environmental change have not developed in a vacuum but are rooted in historical interpretations of and interactions with environment and change (Carey et al. 2014; von Storch and Stehr 2006; Bird 1987).

Environmental changes made by humans have been motivated by connections 
to broader capitalist, global trade economies and networks, physical displays of cultural values, and racially or socially discriminatory policies, amongst other causes (Kahrl 2014; McKenzie 2010; Cronon 2003a; Grove 1996). Historically, people have engineered solutions with specific social intentions or motivations; however, the environmental outcome of these experiments has not always had the intended or expected affect (von Storch and Stehr 2006). For example, early European settlers in North America responded to the unpredictable environmental damages wrought by storms by creating policies that today might be labeled as precautionary such as forbidding grazing on dunes where the plants held sand in place during wind or storm events (Kawashima and Tone 1983). Not only did settlers create change in the American environment, but they expected that their alterations of environment would alter the local climate, as well as unify them as a group of people with strong physical and mental character (Kupperman 1982). Thus, the effect of environmental change was to change both the environment and those making the alteration.

While people perceive some alterations of environment as hidden due to cultural biases and expectations. For instance, fishing and fish drying, undertaken by minority communities in Monterey, California was viewed as a nuisance and health risk while large tourist establishments, with waste running directly into the ocean were viewed as (Chiang 2005). Similarly, in Desolation Sound, British Columbia, yachts are perceived as environmentally benign while Native American groups using the area in traditional ways, but with modern technologies such as chainsaws, park visitors believed Native American park uses were incompatible with the wilderness designation of the park (Clapperton 2012). Each group changes the environment; 
however, the way in which people create this change, rather than the outcome, affects local perceptions of how these changes are occurring.

In her extensive study of the historical adaptability of New Orleans from early French settlement through Hurricane Katrina in 2005, historian Eleonora Rohland $(2017,2015)$ found that knowledge as a precondition for adaptation, path dependent decision-making, political vulnerability, and the interplay of social and economic factors all contributed to the original positioning of New Orleans at a site known to be vulnerable to storms and flooding. Following Hurricane Katrina, the early, imported French engineering of waterways surrounding the city, the continuation of these policies by the American government, and other historically rooted social questions continue to plague adaptation efforts in the city, both leading up to the devastation of Hurricane Katrina and during the subsequent and ongoing recovery (Rohland 2017). Historical preconceptions about how to contain and move water within an urban setting, as well as historical planning decisions on how to site and locate housing and public works within that setting have continued to influence community vulnerability to modern storm events and climate change (Rohland 2017, 2015).

The fixation of landscapes, including the restoration of nature halts the natural flow of culture and the patterns of continuous adaptation on the landscape (Groenewoudt 2012). This is because as societies change and modernize, they adapt and change the landscape to suit new and updating systems and needs. The management of cultural landscapes requires the maintenance of past conditions, which is itself produces a specific pattern use (Melnick 2016; Cronon 2003c, 1995). Even outside of the context of climate change, the modern management of coastal spaces 
represents a continuation of response to and creation of environmental change by current managers. This distinction further divides the scholarly consideration of cultural resources as both factors for preservation and instructive indicators of past environmental adaptations. This research bridges this divide by building on cultural landscape studies, which reveal local drivers of environmental and social change and applied work on historical and continuing patterns of adaptation to look at change overtime, continuing through modern climate adaptation. Rather than interpret the past as stationary and the present as a deviation from an extant state, this research takes the approach that the past, much like the present is a series of changes (DeSilvey 2012).

\section{Historical Case Studies}

Borrowing from the approaches of geographers, anthropologists, and historians in addressing climate change, this research examines how and why colonial leaders, government agencies, and state officials have responded to and generated environmental change in three sites overtime. Cultural resources are a proxy record of the long-standing, human interaction with the environment, evidencing how managers have understood and utilized coastal spaces overtime. and adjust their own construction patterns to the environment, this research contextualizes current management actions in a longer time span (Carey et al. 2014; Melosi 2000), considers climate change as an accelerating feature in the trajectory of coastal environmental volatility (Goudie 2013; Cronon 1995), and sees built responses to climate change as the newest features in the pattern of human shoreline engineering (Rohland 2017; Groenewoudt 2012). 
While this examination of historical environmental perspectives did not start with a hypothesis, it did start with two assumptions. First, the environment is socially constructed, as evidenced by the declining agency afforded to the environment in different periods of human history, as well as the intrusion of social phenomenon such as cultural differences and social prejudices into environmental perspectives. For instance, early European explorers in the Caribbean understood hurricanes through a combination of basic natural science observations and religion, sharply contrasting with current scientific understandings of hurricanes (Schwartz 2015). The social construction of environment is also evident through the changing cultural and temporal understandings of the environment. Over time, different societies, peoples, trade patterns, and resource needs have changed public perceptions and understandings of the ocean (Steinberg 2001). For example, early European settlers perceived the landscape of North America to be a wild landscape despite intensive cultivation, modification, and alteration by Native Americans (Clapperton 2012; Cronon 2003b). The inability of European settlers to recognize changes to the landscape that both did not match their cultural understandings of land modification and were hard to read in a landscape that differed ecologically from their cultural norms suggests that society's view of nature is culturally constructed. Similarly, scientific policies have changed overtime, governing our use of the environment in different ways with goals (Finley and Oreskes 2013).

The second assumption made in this research is that human perceptions of the environment control how people choose to build and spatially organize their communities (Schwartz 2015; Cronon 2003b; Whitney 1996). People design and 
arrange structures and spaces for specific purposes. For instance, the Caribbean world of the colonial period became a stopover point for European shipping (Schwartz 2015). As such, populations moved closer to the water and built extensive coastal infrastructure such as wharves, docks, and other port facilities. The design of modern capital cities such as Brasilia and Ankara to have wide boulevards and planned streets presents a new, modern image to the world (Wakild 2011; Scott 1998). As resource needs, political motivations, scientific assumptions or understandings, cultural viewpoints, and other changes in society occur, cultural constructs of the environment change to suit or fit these changing needs. People construct their environment and changes in this built environment overtime occur as resource needs and perceptions of nature change. Therefore, changes in the built environment evidence shifting perceptions.

This research uses textual and photographic evidence of these changes to interpret perceptions of environment and environmental volatility to outline a longer story of human response to climate change. The "cultural landscape approach" is method of analyzing a landscape that draws on historical, archaeological, and the natural sciences to understand the relationship between culture and nature (Jensen and Hartmeyer 2014). Borrowing from this approach, this research employs a long-term perspective, identifies key drivers of environmental and cultural change, and traces the development and evolution of industries, patterns of use, and responses to the environment overtime (Jensen and Hartmeyer 2014; Mather and Jensen 2011, 2010). Understanding the historical patterns of environmental use may serve to indicate 
where cultural resources are located, but also contribute to an understanding of the modern use of the space (Mather and Jensen 2010).

\section{Evidence, Sources, and Limitations}

In order to examine manager's perspectives on the coastal environment overtime, this research examined texts that discussed the coastline and coastal environment in the three case study locations, as well as texts that described the construction undertaken at these sites, any environmental factors that influenced the location, materials, or methods of this construction, and the reasoning behind any choices made in the built environment. It sought to trace the change in environmental perspectives on environmental volatility over time to understand modern climate change adaptation actions in context. Both the New York Public Library Archives and the Library of Congress Archives had collections of interest in multiple NPS case study sites, while all other archives were specific to one case study site. Error! Reference source not found.. contains a list of the archives visited, the case study sites that the collections were applicable to, and records viewed at each site. The collections included a mixture of official and unofficial texts, photographs, maps, newspaper articles, and notes. 
Table 1. Archives Visited and Collections Referenced

\begin{tabular}{|c|c|c|}
\hline $\begin{array}{l}\text { Archive } \\
\text { Visited }\end{array}$ & National Park Focus & Collections Viewed \\
\hline $\begin{array}{l}\text { New York } \\
\text { Public Library } \\
\text { Archives, New } \\
\text { York City, NY }\end{array}$ & $\begin{array}{l}\text { Colonial National Historical } \\
\text { Park; Gulf Islands National } \\
\text { Seashore }\end{array}$ & $\begin{array}{l}\text { Journal of William Chandler, 1835-1836; Joseph B. } \\
\text { Loring Letters; U.S. State Notes on Florida }\end{array}$ \\
\hline $\begin{array}{l}\text { Library of } \\
\text { Congress } \\
\text { Archives, } \\
\text { Washington, } \\
\text { DC }\end{array}$ & $\begin{array}{l}\text { Gulf Islands National } \\
\text { Seashore; Colonial National } \\
\text { Historical Park }\end{array}$ & $\begin{array}{l}\text { The Records of Archivo National de Cuba; } \\
\text { Jamestown Tercentenary Exposition Collection; } \\
\text { Historic American Buildings Survey: Virginia; The } \\
\text { Jeannette Thurber Connor Collection }\end{array}$ \\
\hline $\begin{array}{l}\text { National } \\
\text { Archives, } \\
\text { College Park, } \\
\text { MD }\end{array}$ & All Parks & $\begin{array}{l}\text { Administrative Records of the National Park } \\
\text { Service }\end{array}$ \\
\hline $\begin{array}{l}\text { University of } \\
\text { California, } \\
\text { Berkeley, } \\
\text { Bancroft } \\
\text { Archives, } \\
\text { Berkeley, CA }\end{array}$ & $\begin{array}{l}\text { San Francisco Maritime } \\
\text { National Historical Park }\end{array}$ & $\begin{array}{l}\text { Bancroft Reference Notes for California; Louis } \\
\text { Bartlett Memoirs; Regional Oral History Office, } \\
\text { San Francisco Bay and Waterfront Collection, } \\
\text { 1900-1965; Regional Oral History Office, Maritime } \\
\text { History and International Longshoremen Series; } \\
\text { George Davidson papers; Archivo General de } \\
\text { Indias Records }\end{array}$ \\
\hline $\begin{array}{l}\text { University of } \\
\text { West Florida } \\
\text { Archives, } \\
\text { Pensacola, FL }\end{array}$ & $\begin{array}{l}\text { Gulf Islands National } \\
\text { Seashore }\end{array}$ & $\begin{array}{l}\text { W.H. Chase Letters; Braxton Bragg Papers; Creel } \\
\text { Richardson Collection; Gulf Islands National } \\
\text { Seashore Records; Fort Barrancas Papers; } \\
\text { Individual File Collections }\end{array}$ \\
\hline $\begin{array}{l}\text { Maritime } \\
\text { Research } \\
\text { Center, San } \\
\text { Francisco, CA }\end{array}$ & $\begin{array}{l}\text { San Francisco Maritime } \\
\text { National Historical Park }\end{array}$ & $\begin{array}{l}\text { Arvid T. Peterson Papers; Joseph Paul Henry } \\
\text { Papers; Voyage to California from the Port of } \\
\text { Boston in the Ship Masconomo 1853; A Tribute to } \\
\text { Mendocino Coast Commercial Fishing; Don } \\
\text { Maskell photographs; William W. Helbush Papers; } \\
\text { Frank S. Brown Papers; }\end{array}$ \\
\hline $\begin{array}{l}\text { Library of } \\
\text { Virginia, } \\
\text { Richmond, } \\
\text { VA }\end{array}$ & $\begin{array}{l}\text { Colonial National Historical } \\
\text { Park }\end{array}$ & $\begin{array}{l}\text { Administrative Records of the National Park } \\
\text { Service }\end{array}$ \\
\hline $\begin{array}{l}\text { University of } \\
\text { Rhode Island, } \\
\text { Kingston, RI }\end{array}$ & All Parks & $\begin{array}{l}\text { Government Publications-Army Corps of } \\
\text { Engineers Records; California Department of Fish } \\
\text { and Game }\end{array}$ \\
\hline
\end{tabular}

These sources record what these authors saw when they viewed the coastal landscape around them and describe how the authors and potentially, the broader communities conceptualized their coastal spaces, valued the resources, and addressed man-made change. In addition to these records, this research made extensive use of 
government documents including military appropriations, Department of Fish and Game reports, and Army Corps of Engineers records. These collections span over a period of decades. The longevity of records of many government agencies allowed for the examination of changes in government and agency priorities in regards to scientific agendas, conservation, and coastal use overtime. While certain gaps exist in the historical record as not every document is preserved or made available, the historical method contextualizes evidence in broader patterns of understanding through other primary and secondary sources, allowing this research to draw meaning from potentially fragmentary evidence (Cronon 2004; Smith and Lux 1993; Grigg 1991).

The outcomes of the historical research approach differ from other fields of study in validation and generalizability (Cronon 2004). Historical research examines context dependent events and evidence. As such, the rigor and validity of the research comes from the fact that the subject of study is not removed from the complexity of a real-world situation (Cronon 2000, 1993). The following chapters discuss the historical perceptions of change in the areas that are today Gulf Islands National Seashore, Colonial National Historical Park, and San Francisco Maritime National Historical Park. The outcomes of this research are applicable at the study site, but the broader patterns of historical events this research uncovers, the methods this research undertakes, and the questions that result from each site have applications for the study of climate change adaptation at other coastal sites with cultural heritage components as managers examine how past policies continue to influence climate adaptation practices. 


\section{Summary}

Cultural resources are one piece in the larger conversation about coastal adaptation to climate change. This research moves outside of the definition of cultural resources as valued in today's society for tourism and examines cultural resources for the different uses and values they have held overtime. Historical research allows scholars to examine patterns that may not be visible in studies that focus only on the present. Current approaches to climate change and cultural resources in the National Park Service suggest that past adaptations can inform climate change adaptation for cultural resources. The following studies of three coastal national parks from the time of early European colonial presence through the current management of climate change adaptation take a landscape approach and examine ongoing patterns of change in the management of the built environment from the period of early European settlement in the United States through the present. The outcomes of this study can both inform current adaptation practices by underlining the historic roots of problems in current management approaches. The following six chapters are informed by methods and approaches from historical perspectives in multiple social science disciplines, examining the changes in the built environment in the past, through the present climate change.

Various studies identify barriers for National Park Service and other land management agency employees to implement climate change adaptation measures from this vision of maintaining resources in their current condition given climate change pressures (Kemp et al. 2015; Bierbaum et al. 2013; Archie et al. 2012; 
Jantarasami, Lawler, and Thomas 2010). Chapter 2 presents the outcomes of key informant interviews with cultural resource managers at the three national park sites and identifies barriers specific to the climate change adaptation of cultural resources. The following three chapters present case studies that explore the historical roots of the conceptual barriers to climate change identified in Chapter 2 at Colonial National Historical Park in Virginia, Gulf Islands National Seashore in Florida and Mississippi, and San Francisco Maritime National Historical Park in California.

Chapter 3 examines the commemorative landscape of Colonial National Historical Park. In this park, managers have historically linked the space, including the shape of the coastline and the character of the forest and marsh with a broader American origin story and identity. Chapter 4 examines Gulf Islands National Seashore in Florida and Mississippi. Built on the shifting sands of the Gulf Coast barrier island system, in this park, early military manager's ideas of permanence were quickly challenged by Gulf Coast hurricanes. Chapter 5 considers the built shoreline of San Francisco Maritime National Historical Park. In this park, cultural resources are part of a moving puzzle of constructed, urban and overlapping park uses. Chapter 6 takes a combined look at the three case study sites, tracing the trajectory of national heritage management priorities overtime and identifying how national priorities manifest at the local park level. Finally, the conclusion discusses how this multimethod study contributes to the understanding of the adaptation of cultural resources in the context of climate change and provides recommendations for coastal managers to undertake climate change adaptation planning and action moving forward. 


\title{
CHAPTER 2: INSTITUTIONAL AND CONCEPTUAL BARRIERS TO CLIMATE
}

\section{CHANGE ADAPTATION FOR CULTURAL RESOURCES}

\begin{abstract}
Climate change is increasing the speed at which tangible coastal cultural heritage is changing in character or being lost through weathering, erosion, and inundation (Morgan et al. 2016). Damages to coastal archaeological sites, loss of access to historical sites, and the alteration of cultural landscapes will force changes in the way researchers can study sites, tourists can enjoy places, and descendant and local communities can utilize and relate to landscapes. In the United States, the National Park Service is a primary coastal cultural resource management organization. The National Park Service has been working on climate change adaptation for cultural resources for at least a decade; however, there are few examples of parks in which long range climate change adaptation plans for cultural resources have been implemented. Building from twenty semi-structured interviews with cultural resource managers in three parks, we found that institutional structures within the National Park Service, as well as historical conceptual framings specific to the research, recreational, and interpretive values of cultural resources act as barriers to managers' ability to design and implement climate change adaptation plans. We present opportunities for technological, management, and policy changes to help coastal managers overcome these barriers.
\end{abstract}

\section{Introduction}

Cultural resources are the "sites, things, and practices a society regards as old, important, or worthy of conservation (Brumann 2015, 414).” Coastal communities value cultural resources for the tourist economies, sense of place, cultural or religious significance, educational facets, and the potential of these resources to contribute to research and understanding of coastal history (Green 2015; Tengberg et al. 2012; Claesson 2011). The materials, spatial contexts, and geographic arrangements of cultural sites are constantly threatened by weathering, erosion, and looting. Builders and designers constructed structures and sites for specific local climate and climate risks (IPCC 2014; WHC 2006). Coastal climate change factors including shifting species assemblages, changes in fog and wind patterns, temperature fluctuations, more intense storms and accompanying surges, sea level rise, and enhanced coastal erosion, 
increasingly threaten these sites (Morgan et al. 2016; Green 2015; Brimblecombe 2014; Sabbioni and Bonazza 2009; Sabbioni et al. 2008; Brimblecombe, Grossi, and Harris 2006; Cassar 2005). The damaging impacts of climate change on cultural resources will alter the look, feel, function, and meaning of coastal landscapes.

The National Park Service (NPS) manages the largest collection of cultural resources in the United States and provides guidance to numerous state, regional, and local preservation agencies through state historic preservation offices, the National Register of Historic Places, and other programs. NPS defines tangible cultural resources as archaeological sites, historic structures, cultural landscapes, ethnographic resources, and collections materials (NPS 2006). The Organic Act mandates that NPS preserve the natural and historic resources of the national parks "by such means as will leave them unimpaired for the enjoyment of future generations, (United States Congress 1916)." Projected climate change impacts on resources will require managers to take adaptive actions to protect resources since the status quo may no longer represent a static resource condition (Colwell et al. 2012).

To determine the risk, select resources to preserve and address these changing preservation needs given projected climate change impacts, management agencies with cultural resource responsibilities have started developing climate change adaptation plans. Climate change adaptation planning may take many forms. However different planning processes often share the steps of identifying goals or targets to be protected, using scientific projects to estimate the impact on this goal or target resource or condition, and identifying and implementing management options to reduce the exposure or sensitivity of resources to climate change impacts or increase 
their ability to adapt and withstand these impacts (Rockman et al. 2016; Bierbaum et al. 2013; Sheridan and Sheridan 2013; Amberg et al. 2012; Glick, Stein, and Edelson 2011; Sabbioni, Brimblecombe, and Cassar 2010; Baron et al. 2009; Fussel 2007; Fussel and Klein 2006; Toscano 2004).

The threat of climate change to cultural heritage properties is well established in the literature (Morgan et al. 2016; Brimblecombe 2014; Sabbioni, Brimblecombe, and Cassar 2010; Sabbioni et al. 2008; Brimblecombe, Grossi, and Harris 2006). Preservationists, cultural resource, and climate change experts have issued calls to action around the topic of climate change and cultural heritage management (Markham and Wiser 2015; Holtz et al. 2014; NPS 2010; Cassar 2005). And guidance is available for assessing resource vulnerability to climate change (Beavers, Babson, and Schupp 2016). However, as climate change adaptation planning has gotten underway, cultural resources have been underrepresented in climate change vulnerability assessments (Thompson, Staudinger, and Carter 2015) and the implementation of climate change adaptation measures, for both natural and cultural resources, has been slow (Fatoric and Seekamp 2017b; Jantarasami, Lawler, and Thomas 2010; Baron et al. 2009).

Researchers have examined barriers to climate change adaptation planning and action to determine what is stalling implementation in federal agencies including NPS (Fatoric and Seekamp 2017b; Ellenwood, Dilling, and Milford 2012; Jantarasami, Lawler, and Thomas 2010; Baron et al. 2009), as well as state agencies (Archie et al. 2012) and local governments (Amundsen, Berglund, and Westskog 2010). In land management agencies, climate change adaptation planning for natural resources may 
not consistently or frequently represent the top planning priority (Archie et al. 2012;

Ellenwood, Dilling, and Milford 2012; Jantarasami, Lawler, and Thomas 2010). If the agency is interested in climate change adaptation planning or action, the lack of support from agency leadership, either directly, or indicated through a lack of designated funding, personnel, training, time, or incentive can serve as a barrier to action (Kemp et al. 2015; Lemieux et al. 2013; Archie et al. 2012; Amundsen, Berglund, and Westskog 2010; Jantarasami, Lawler, and Thomas 2010). And a lack of clarity on agency priorities, goals, or intended outcomes, can also bar climate adaptation action at the agency level (Jantarasami, Lawler, and Thomas 2010; Smith and Travis 2010; Baron et al. 2009). In a study specifically examining barriers to climate change adaptation for cultural resources, Fatorić and Seekamp (2017a) identified sixteen barriers specific to decision-making for cultural resources and climate change within the broader categories of institutional (guidance, policies and strategies), technical (historic preservation-based knowledge), and financial barriers. Building on previous studies on barriers to climate change adaptation, this study explores barriers specific to cultural resource adaptation planning in coastal spaces and contextualizes barriers to management in the climate change adaptation process of three coastal national parks. We hypothesized that the lack of representation of cultural resources in climate change adaptation planning was caused by challenges associated with the unique uses, features, and functions of cultural resources and the policies that have historically governed the uses of these objects, sites, and places. Qualitative interviews ( $\mathrm{n}=20)$ with cultural resource managers, archaeologists, historians, historical preservationists, and interpretive staff from three NPS units in the 
Northeast, Southeast and Pacific-West NPS regions, revealed that the challenges managers are facing have roots in the institutional structures and conceptual frameworks that guide NPS cultural resource management. After identifying the roots of these challenges, we present opportunities for managers overcome barriers and move forward with adaptation planning for these critical resource components of coastal heritage, recreation, and research.

\section{Methods}

NPS management priorities, as well as climate change vulnerabilities, are sitespecific and dependent upon the resources in each park (Smith and Travis 2010; Schroter, Polsky, and Patt 2005). Therefore, we undertook a case study approaching, examining Colonial National Historical Park, Gulf Islands National Seashore, and San Francisco Maritime National Historical Park. These three sites were selected through an information-oriented process that sought maximum-variation between sites (Yin 2003; Flyvbjerg 2006). Each site was selected from a pool of coastal NPS units ( $\mathrm{n}=97)$ in which the literature identified a climate change risk to the cultural landscapes, structures, or other tangible landscape features (Peek et al. 2015). From coastal sites with an established climate change risk to cultural resources, we selected sites for maximum variation in coastal location, morphology, timing in the vulnerability assessment process, and the cultural resources represented at the site. Table 1 shows the selection criteria and case study sites. 
Table 2. Case Study Site Selection Criteria

\begin{tabular}{|c|c|c|c|c|c|c|}
\hline Park & $\begin{array}{l}\text { Climate } \\
\text { Change } \\
\text { Risk } \\
\text { Factor }\end{array}$ & $\begin{array}{l}\text { Park } \\
\text { Location, } \\
\text { NPS } \\
\text { Region } \\
\end{array}$ & $\begin{array}{l}\text { Coastal } \\
\text { Characteristics } \\
\text { and } \\
\text { Morphologies }\end{array}$ & \begin{tabular}{|l|} 
Vulnerability \\
Assessment \\
Process
\end{tabular} & $\begin{array}{l}\text { Cultural } \\
\text { Resources }\end{array}$ & $\begin{array}{l}\text { Number of } \\
\text { Key } \\
\text { Informants }\end{array}$ \\
\hline $\begin{array}{l}\text { Gulf } \\
\text { Islands } \\
\text { National } \\
\text { Seashore }\end{array}$ & $\begin{array}{l}81 \% \text { high } \\
\text { exposure } \\
\text { (Peek et al. } \\
2015 \text { ) }\end{array}$ & $\begin{array}{l}\text { Florida and } \\
\text { Mississippi, } \\
\text { Southeast } \\
\text { Region }\end{array}$ & $\begin{array}{l}\text { Heavily altered } \\
\text { by human } \\
\text { endeavors, } \\
\text { barrier island } \\
\text { system }\end{array}$ & $\begin{array}{l}\text { Completed } \\
\text { through the } \\
\text { Geoscientists- } \\
\text { in-the-Parks } \\
\text { Program }\end{array}$ & $\begin{array}{l}\text { Spanish } \\
\text { colonial, Civil } \\
\text { War, World } \\
\text { War II, Native } \\
\text { American } \\
\text { archaeological } \\
\text { sites }\end{array}$ & 6 \\
\hline $\begin{array}{l}\text { Colonial } \\
\text { National } \\
\text { Historical } \\
\text { Park }\end{array}$ & $\begin{array}{l}\text { Projected } \\
\text { sea level } \\
\text { rise and } \\
\text { coastal } \\
\text { changes } \\
\text { (Schupp, } \\
\text { Beavers, } \\
\text { and Caffrey } \\
\text { 2015) } \\
\end{array}$ & $\begin{array}{l}\text { Virginia, } \\
\text { Northeast } \\
\text { Region }\end{array}$ & $\begin{array}{l}\text { Heavily altered } \\
\text { by human } \\
\text { endeavors, tidal } \\
\text { river system, } \\
\text { marshes }\end{array}$ & $\begin{array}{l}\text { Underway } \\
\text { under the } \\
\text { leadership of } \\
\text { the NPS } \\
\text { Northeast } \\
\text { Region } \\
\text { Climate } \\
\text { Change } \\
\text { Program }\end{array}$ & $\begin{array}{l}\text { American } \\
\text { Revolution, } \\
\text { archaeological } \\
\text { sites, early } \\
\text { colonial }\end{array}$ & 5 \\
\hline \begin{tabular}{l|} 
San \\
Francisco \\
Maritime \\
National \\
Historical \\
Park
\end{tabular} & $\begin{array}{l}43 \% \text { high } \\
\text { exposure } \\
\text { (Peek et al. } \\
2015 \text { ) }\end{array}$ & $\begin{array}{l}\text { California, } \\
\text { Pacific- } \\
\text { West } \\
\text { Region }\end{array}$ & $\begin{array}{l}\text { Heavily altered } \\
\text { by human } \\
\text { endeavors, } \\
\text { rocky and } \\
\text { sandy, tidal } \\
\text { mudflats } \\
\text { shoreline }\end{array}$ & $\begin{array}{l}\text { Partner } \\
\text { projects have } \\
\text { examined } \\
\text { vulnerability } \\
\text { and adaptation } \\
\text { for features } \\
\text { within the } \\
\text { park; No } \\
\text { overarching } \\
\text { project } \\
\text { underway }\end{array}$ & $\begin{array}{l}\text { Coastwise } \\
\text { transport, } \\
\text { Chinese } \\
\text { immigration, } \\
\text { African- } \\
\text { American } \\
\text { maritime } \\
\text { experience }\end{array}$ & 9 \\
\hline
\end{tabular}

For a 10-month period beginning in 2016, we conducted research interviews

with 20 key informants from the three National Parks and the corresponding regional

offices. At each case study site, we contacted the Chief of Cultural Resources, the

Chief of Interpretation, staff responsible for climate change initiatives, members of the

curatorial staff, and Natural Resource Chiefs for interviews. We conducted three focus

group interviews with a total of 8 informants, while the remainder of informants were

interviewed individually, either in person or over the phone. The semi-structured

interview format allowed key informants considerable leeway to broach topics they 
believed to be most important and encouraged informants to discuss their observations of situations that arise in their daily work.

The framework questions for the semi-structured interview were divided into three categories, as follows (see Appendix for a complete guide to interview questions):

1. Observed changes or stability of condition of cultural resources

2. Use and value of cultural resources in the park

3. Decision-making and prioritization procedures for cultural resources When given permission $(n=19)$, we voice recorded interviews then transcribed, coded and analyzed these interviews for content and themes. Statements made during the interviews were systematically grouped, according to topic, and analyzed to determine overarching themes and patterns (Babbie 2013; Toulmin 2003; AttrideStirling 2001; Neuman 1997). We used an open coding framework, and identified themes that arose in the transcripts, while looking for emergent frameworks within the three thematic sections of questions. Nvivo coding software expedited the data analysis process by making key words, terms, and themes easily searchable (Richards and Richards 1994). We validated and contextualized interview transcripts by reviewing NPS publications, documents, reports, and events (McDowell 2010).

\section{Results: Conceptual and Institutional Barriers to Cultural Resource Adaptation}

The barriers that key informants identified to adapting cultural resources to climate change fell into two categories: institutional and conceptual. We define institutional barriers as challenges that result from the existing structures and 
frameworks within NPS. Institutional barriers include problems in prioritizing adaptation action, and issues in distinguishing, and therefore responding to, normal climate conditions versus climate change. We define conceptual barriers as challenges that result from features specific to the features, uses, or research requirements of cultural resources. Conceptual barriers include problems in prioritizing which resources to protect or adapt and challenges in managing the same resources for both interpretive and research uses. Table 2 shows the type of barrier and example statements of how the barrier may appear in a coastal management context. 
Table 3. Results of Interview Coding: Conceptual and Institutional Barriers to Cultural Resource Adaptation

\begin{tabular}{|c|c|c|}
\hline Barrier Type & Barrier & $\begin{array}{l}\text { Contributing Examples (Parenthetical number indicates key } \\
\text { informant) }\end{array}$ \\
\hline \multirow[b]{2}{*}{ Institutional } & $\begin{array}{l}\text { Decisions are } \\
\text { Dependent on } \\
\text { other } \\
\text { Management } \\
\text { Actions }\end{array}$ & $\begin{array}{l}\text { "In theory, it's the enabling legislation. In fact, it's whatever the } \\
\text { current priorities of the Washington Office happen to be." (1.2) } \\
\text { "If you don't have a road, it's going to affect everything out there, } \\
\text { because then you're going to have to have boat operations to get } \\
\text { everything you need out there and there's no way." (1.4) } \\
\text { "... somebody will put a project in } 5,6 \text { years ago and by the time it } \\
\text { gets funded, they're not even here anymore and...there's no project } \\
\text { history." (3.1) }\end{array}$ \\
\hline & $\begin{array}{l}\text { Climate } \\
\text { Change is } \\
\text { Compounding } \\
\text { Other } \\
\text { Maintenance or } \\
\text { Management } \\
\text { Challenges }\end{array}$ & $\begin{array}{l}\text { "And then as sea level rise or more frequent storms start } \\
\text { bombarding [the fort] because it's exposed out there, the } \\
\text { maintenance that we do now will be even more important for } \\
\text { keeping it intact." (3.1) } \\
\text { "It's sometimes difficult to detect the incremental changes that } \\
\text { climate change is bringing. We're in such a dynamic system to } \\
\text { begin with." (1.3) } \\
\text { "In a lot of places, [climate change] makes those other stressors } \\
\text { worse." (2.2) }\end{array}$ \\
\hline \multirow{2}{*}{ Conceptual } & $\begin{array}{l}\text { Intentional } \\
\text { Prioritization } \\
\text { of which } \\
\text { Resources to } \\
\text { Protect is } \\
\text { Largely } \\
\text { Unprecedented }\end{array}$ & $\begin{array}{l}\text { "If it was a matter of what was going to be the top one, it would be } \\
\text { the ones that are on higher ground right now." (1.2) } \\
\text { "...we identify a really high priority location or fortification or } \\
\text { road or something that needed to be prioritized because of an } \\
\text { imminent impact..." (3.1) } \\
\text { "Well, most of our resources are National Historic Landmarks, so } \\
\text { they get high points for anything that they need." (3.2) }\end{array}$ \\
\hline & $\begin{array}{l}\text { Research and } \\
\text { Interpretive } \\
\text { Uses Require } \\
\text { Different } \\
\text { Management } \\
\text { Actions }\end{array}$ & $\begin{array}{l}\text { "The only way to do it right and open it is you've got to document } \\
\text { it... document it, photograph it, put up an exhibit out of that, but } \\
\text { then remove the stuff that's going to kill somebody...then you can } \\
\text { have a battery that can be enjoyed." (1.4) } \\
\text { "It's really interesting because again, for many decades, this park } \\
\text { had the perspective that climate change had had a huge effect on } \\
\text { you know, the disappearance of Jamestown Fort. Now that, since } \\
\text { '94 that's changed, people....never understand that that was the } \\
\text { perspective." (2.5) }\end{array}$ \\
\hline
\end{tabular}

\section{Institutional Barriers}

Informants discussed many barriers to climate change adaptation that stemmed from institutional factors including limited institutional support through both financial and staffing resources and policies that govern cultural resource management, 
organizational partnerships, and project planning. As managers discussed the situations in which they were unable to take management actions to address climate change, these various challenges fell into two categories of barriers to planning and action: decisions that are dependent on other management priorities and climate change compounding existing maintenance challenges.

\section{Decisions are Dependent on other Management Actions}

Managers are aware of and concerned about climate change impacts on cultural resources; however, in many cases, managers identified other projects in their schedules that took priority or prevented consistent and ongoing staff time for climate change adaptation. Projects that concern historic structures but are tied to infrastructure such as the adaptive reuse of a historic building for concessions, may garner more attention, affecting the ability of staff to focus on climate adaptation projects within the park, or obligating staff capacity and financial resources on sites and structures that are not the most at risk to climate change pressures or the highest priority resources for protection based on historic significance. In partnership with the U.S. Army Corps of Engineers, and with friends' groups, GUIS and SAFR managers discussed how partnership projects can arise, sometimes quickly, and affect the amount of time staff can devote to other and long-term projects, including climate change adaptation planning. Additionally, informants from the Pacific-West Region suggested that adaptation was hindered by the lack of a dedicated person on staff to address climate change adaptation. 
In addition to difficulties managers face in prioritizing staff time for climate change adaptation, the long-term nature of climate change adaptation efforts directly conflicts with existing institutional management pattern based of 5-year funding cycles. In between the time staff apply for and receive project funding, park staff my transfer to other locations, the key issues to address in the park may change, or environmental changes may enhance the speed of resource deterioration, challenging staff to implement a project that they did not design, that may no longer be a top priority, or which may no longer be adequately funded. This funding cycle presents a barrier to addressing climate change questions as quickly as they may become problematic, or to addressing the most pressing current issue rather than the most important issue at the time the request was written.

\section{Climate Change is Compounding Other Maintenance or Management Challenges}

Many managers identified insufficient routine maintenance as the biggest threat to cultural resources in their parks or regions, a concern echoed both in the field of historic preservation, and in coastal and environmental conservation (IPCC 2014; Haugen and Mattsson 2011; Sabbioni et al. 2008; Cassar 2005). Ongoing maintenance is required to maintain site conditions given weathering, visitor impacts, and vandalism, in addition to climate change. Despite representing climatically distinct region, coastal managers from Florida, California, and Virginia address challenges in preserving historic resources in the coastal environment, citing salt, fog, and coastal erosion as long-understood threats to the resources. "If you've got fortifications on the seacoast, it's just, you know, Mother Nature (Personal Communication 2016)." 
Managers at GUIS also cited vandalism by visitors as part of the ongoing maintenance challenge.

Most managers were unable to determine a preservation issue was related to routine weathering, climate change, or a combination of the two. One manager at SAFR suggested, "[The Fort] is old and needs a needs work to just keep it intact as it is. And then as sea-level rise or more frequent storms start bombarding it because it's sort of exposed out there, the maintenance that we do now will be even more important for [keeping] it intact. It's above most of the sea-level rise projections, but definitely being exposed out there and the projections of more intense storms, definitely important to fortify it as much as possible (Personal Communication 2016)." Climate change impacts may appear as incremental changes in daily maintenance tasks, such as installing dehumidifiers in the basements of historic structures or clearing boring organisms and algae from ship hulls more often. However, if managers address problems that are both persistent and increasing in intensity with short-term fixes, these management actions may be ineffective or may result in staff and financial resources being applied to stop-gap measures rather than a longer-term preservation strategy.

\section{Conceptual Barriers}

In addition to challenges posed by existing policies and programs in leveraging management time, technical, and financial resources to address climate change adaptation, informants expressed challenges stemming from how managers use cultural resources. These challenges include determining what information can 
contribute to prioritization and addressing conflicting park management goals that may be siloed between different employees or organizational divisions. As managers discussed the situations in which they were unable to take management actions to address climate change, these various challenges fell into two categories of barriers caused by conceptual features of cultural resources: intentional prioritization of which resources to protect is largely unprecedented and research and interpretive uses of the same resource require different management actions.

Intentional Prioritization of which Resources to Protect is Largely Unprecedented

NPS staff will be faced with deciding which cultural resources to prioritize for protection through adaptive measures, and which resources to allow to be altered, submerged, or destroyed by climate change factors. Currently, managers protect cultural resources as dictated by NPS and park legislation. At each location, managers were unanimously worried about the coastal artifacts outlined in this legislation, citing both location and material type as key factors in site vulnerability to climate change. Managers in San Francisco expressed the greatest concern over large metal armament, accompanying coastal fortifications and bunkers. GUIS managers also expressed concern about metal artifacts, as well as coastal military fortifications, citing the movement of sand in barrier island systems as an ongoing threat to the resources. Managers at COLO believed buried archaeological deposits to be the most vulnerable resources in their park, citing ongoing coastal erosion, sea level rise, and salt water intrusion as important considerations. Each of the resource types of greatest concern to managers aligned closely with park preservation legislation specifying which cultural 
resources the park interprets and protects. In addition, informants said National

Historic Landmarks (NHLs) ${ }^{1}$ receive the most attention and are maintained to the highest standard.

However, within the categories of resources for which managers expressed concern, they completely disagreed on how to prioritize these resources for protection and adaptation. Informants in the Pacific-West Region found public input through a public process on climate change helpful as they begin to think about climate change adaptation. However, informants in the Southeast Region suggested that the public interest may be particularly focused on certain resources, suggesting that lighthouses, forts, and Civil War sites have contingencies of public support, thus leaving other resources such as prehistoric buried archaeological sites, more exposed to damages. Additionally, managers disagreed on whether the most or least vulnerable resources should be prioritized for adaptation and protection. Some managers believed priority should go to sites that are considered most vulnerable to climate change, while others believed priority should go to sites that are in better condition and have a better chance of withstanding climate hazards, even though these sites may not be as vulnerable to sea level rise or increasing coastal erosion. Finally, when asked about whether especially rare sites would receive priority consideration for climate change impacts, informant's responses were mixed. Many informants felt that rare sites would rise to the top through competitive funding reviews. However, outside of this review process,

\footnotetext{
${ }^{1}$ National Historic Landmarks are a subset of resources listed on the National Historic Register. National Historic Landmarks represent approximately .03\% of sites listed on the National Historic Register and are held to higher standards of historic integrity, which refers to the condition or preservation of the site or structure. While National Register properties may represent sites of local or regional significance, National Historic Landmarks are significant to the history of the nation overall.
} 
and existing designation procedures such as NHLs, there is not a system to prioritize rare sites or check for regional or national site diversity.

Research and Interpretive Uses Require Different Management Actions

Much like the multiple and interacting uses of coastal spaces, coastal cultural resources are used both for academic research and for the enjoyment and education of locals and tourists. These uses have different preservation requirements. All but one informant indicated that park visitors accept the interpretation of sites without the presence of physical artifacts or structures, making this use renewable. However, archaeological work and the study of the site require the physical preservation of artifacts, making this use non-renewable. In San Francisco, NPS interprets the Panama Pacific Exposition without any physical remains of the event. At COLO, "up until 1994, the assumption had always been that James Fort was completely washed away. If you had come here in say 1976 or $1950 \ldots$ it was the fort is completely washed away, period.” However, in 1994, archaeological investigations found the partial remains of James Fort onshore. While interpreters were able to tell the story of James Fort both in the river and now that it has been found on land, the rediscovery of the fort on land has allowed for extensive research at the site. Park managers who focus on resource preservation may have different ideas on climate change adaptation or prioritization than managers who focus on educational or visitor programs.

\section{Discussion: Understanding and Overcoming Barriers in Cultural Resource}

\section{Adaptation}


As coastal managers begin to plan for and undertake climate change adaptation actions, institutional management structures that focus on daily rather than long-term maintenance and prioritize dual-use or other specific projects may create barriers to effective climate change adaptation action. Conceptual barriers stem from the complexity of prioritizing cultural resources for preservation with little historic precedent, as well as changing patterns of which histories within complex and overlapping coastal landscapes are of interests to locals and visitors that may prescribe different uses of the landscape. Climate change represents an unprecedented challenge for management agencies and institutions. Historical institutional structures and conceptual understandings and goals of management need to be examined to determine how these structures and ideas are creating barriers to coastal climate change adaptation (Adamson, Hannaford, and Rohland 2018). The remainder of this section will address this question and present opportunities for managers to overcome barriers to climate change adaptation planning and action for cultural resources.

\section{Guidance for Resource Prioritization}

Difficulties in prioritizing resources were a top concern for key informants from all three case studies. Prioritization requires managers to select which resources will be protected from climate change, and which ones will not. Managers have historically faced decisions about which resources to research, preserve, or display as heritage (Ashworth 2013; Lowenthal 1996). However, because climate change impacts are predicted, this form of slow disaster provides an opportunity to plan for wide-scale impacts, allowing managers and stakeholders to strategize their adaptation 
actions. NPS defines resource priority as a combination of vulnerability and significance (Rockman et al. 2016). Resource significance can be defined by listing or potential listing on the National Register of Historic Places, or through factors such as research potential, visitor use and access, or adaptive reuse potential. In addition to the challenge of determining present resource significance, the meaning of different cultural sites and landscapes changes relative to the time-period and audience. Recently, NPS has expanded to include urban, industrial sites that may not have been considered important just decades ago. The sites and structures that are selected for preservation, interpretation, and presentation were selected through a political process, and are not necessarily representative of the diversity of the past (Lowenthal 2015; de Groot 2009). Climate change and associated decision-making will add another layer of political complexity to the preservation of cultural heritage. Sites omitted from park legislation in the past may require special consideration to work towards a collection of American cultural heritage that is as representative as possible of a diverse American history.

In addition to association with important people or events in the past, the condition of the resource, or resource integrity, contributes to whether it is considered significant using National Register criteria. Resources that have begun slowly eroding or experiencing damage that may be exacerbated by climate change may be at a disadvantage for significance assessment. Existing institutional requirements for resource condition need to be reconsidered given climate change realities. In NPS, Gateway National Recreation Area prioritized each of their park resources starting before and continuing after Hurricane Sandy as part of their General Management 
Plan update (Mahan 2015; NPS 2014). The process that Gateway National Recreation Area conducted to prioritize cultural resources was specific to the resources of that location; however, other parks may find lessons in the challenges and outcomes of this process.

\section{Balancing Renewable and Non-Renewable Uses}

Cultural resources have three unique management requirements: first, some cultural resources require maintenance or interference to persist in a stable condition. Second, cultural resources may be constructed and degraded at a faster time scale than some natural features. Third, quantitative means of preservation (i.e. preserving at least a set number of acres or a specific number of representative sites) may not be valid for unique cultural resources. These challenges are compounded by the fact that cultural resources may include living resources such as key plant species and have both renewable and non-renewable uses. Archaeological sites are irreplaceable; however, the living features that contribute to cultural landscapes and ethnographic resources are renewable (Beavers, Babson, and Schupp 2016). While the materials and spatial context that form an archaeological site are non-renewable, the history of the area, as informed by archaeological and historical research can be told to visitors repeatedly, without additional resource inputs. However, the loss of the non-renewable qualities of the resources may limit future research, which can clarify, improve, or correct past academic understandings.

DOI preservation requirements for historic structures may not allow for continuous replacement of certain features due to weather conditions or certain 
modernizations for changing weather patterns or combinations (Grimmer 2017).

Manmade sites and structures were once dynamic places that were updated as needs changed (Guerrini and Dugan 2010). Once these sites become historic structures, they are preserved in a more static situation. Many informants in this study discussed a conflict between the updates to sites and structures in the past and the preservation practices of today. Because sites and structures are now used to display past conditions, the adherence to past building materials is of greater importance. NPS is actively working to develop guidance for the assessment of both natural and cultural systems in the face of climate change and has put forward a series of documents to that end (Beavers, Babson, and Schupp 2016; Jarvis 2016; Morgan et al. 2016;

Rockman et al. 2016; Jarvis 2014). However, because many climate change adaptation procedures start by identifying, rather than questioning, the preservation goals of the park, given climate change projections, managers may not be able or encouraged to rethink whether more adaptive historic preservation standards, in terms of material, condition, and appearance, could free staff capacity and financial resources to focus on more vulnerable coastal cultural resources, such as archaeological sites, which may not be able to be protected with more adaptive construction measures.

\section{Adaptation Opportunities for Cultural Resources}

In addition to barriers, discussions with key informants highlighted potential opportunities for overcoming these barriers. As cultural resource management organizations develop methods for climate change adaptation for resources, opportunities to document actions, as well as changes to rethink best practices may 
enhance management moving forward. Some key informants suggested input from the public was helpful in the prioritization of action and preservation in the adaptation process. This coordination with the community to help inform priorities may also represent an opportunity to update the preservation priorities of the park to be more representative of the priorities of a diverse and modern public. The lack of established prioritization methods could allow for increased public input or community consultation during the prioritization process. Preservation has always necessitated choices. Sites and structures have been lost due to development and other pressures, but climate change affords an opportunity to explain the reasons for priority setting and contemporary thought behind preserving one site over another.

Preservation of historic structures aims for the representation of a certain moment in time. However, many informants discussed the inherent contradiction between the preservation of a moment in time when the historic use of a site would have included dynamic updates to bolster the site against climatic conditions. However, these past historic adaptations could be reconsidered for their historic authenticity. Recent publications by NPS, starting with Revisiting Leopold in 2012, and established further with Memorandum 14-02 in 2014 and Directors Order 100 in 2016 each recognize that cultural resources will be confronted with climatic as well as social and cultural shifts, and may require interference to maintain their condition. In 2016, the Cultural Resources Climate Change Response Strategy was published to help interpret and guide the application of Memorandum 14-02. While these documents encourage changes in management perception and policy, the Secretary's standards on historic preservation that govern day-to-day maintenance, as well as the 
National Historic Preservation Act and National Environmental Policy Act have yet to be updated. The new management paradigm represented by these documents presents an opportunity to update historic preservation guidelines to include ongoing climate maintenance as an authentic, integral feature of site preservation. This may allow sites to adapt to climate change while retaining their integrity.

Finally, all but one informant in this study believed that the interpretation of cultural heritage sites for visitors could continue without the tangible presence of cultural artifacts. However, the ability to maintain some interpretive functionality of a site, without the preservation of corresponding artifacts is not currently an explicit tool for the prioritization of adaptation resources given climate change. If these objects are not required for interpretation and site education, prioritization of cultural resources in the face of climate change may instead focus on the research potential of sites, structures, and artifacts. Focusing on the research potential presents challenges because it is difficult to determine which sites will be important in the future. However, this more targeted preservation strategy may aid managers in making decisions. And improving and developing technologies may provide better opportunities for preserving images, dimensions, and spatial information from sites that cannot be researched or recovered before they are lost to climate change, either due to a lack of time, financial resources, or staff capacity. Table 3 summarizes the barriers and corresponding opportunities as integrated climate change adaptation planning progresses. 
Table 4. Barriers and Opportunities for Cultural Resource Climate Change Adaptation

\begin{tabular}{|l|l|}
\hline Barrier & Opportunity \\
\hline $\begin{array}{l}\text { No Established Method for } \\
\text { Prioritization }\end{array}$ & $\begin{array}{l}\text { Update preservation priorities to align with modern, diverse } \\
\text { community perspectives and priorities }\end{array}$ \\
& $\begin{array}{l}\text { Document modern prioritization decisions to inform future } \\
\text { managers }\end{array}$ \\
\hline $\begin{array}{l}\text { Historic Preservation Requirements } \\
\text { Climate Change }\end{array}$ & $\begin{array}{l}\text { Expand coastal site regulations, management plans, and } \\
\text { partnerships to allow for future climate realities such as the } \\
\text { management of additional submerged coastal archaeological } \\
\text { sites }\end{array}$ \\
& $\begin{array}{l}\text { Redefine historic preservation best practices to include ongoing } \\
\text { structural adaptation, updates, climate adaptive measures, } \\
\text { replacement of components as aligned with, rather than } \\
\text { detracting from, site integrity }\end{array}$ \\
\hline $\begin{array}{l}\text { Cultural Resources are Both } \\
\text { Renewable and Non-Renewable }\end{array}$ & $\begin{array}{l}\text { Prioritize resource preservation for non-renewable uses } \\
\text { Utilize new documentation and dissemination technologies to } \\
\text { preserve sites that are lost or let go for current and future } \\
\text { research and interpretation }\end{array}$ \\
\hline
\end{tabular}

\section{Conclusion: Next Steps for Cultural Resources and Climate Change Adaptation}

The institutional and conceptual barriers identified through semi-structured

interviews with cultural resource managers at three coastal national parks are hindering coastal managers efforts in developing and implementing climate change adaptation plans to protect coastal cultural heritage. In addition to institutional barriers to climate change adaptation (Fatoric and Seekamp 2017b; Archie et al. 2012;

Ellenwood, Dilling, and Milford 2012; Amundsen, Berglund, and Westskog 2010;

Jantarasami, Lawler, and Thomas 2010), conceptual barriers specific to the historically-rooted management patterns and functions of cultural resources (Eisenack et al. 2014) are affecting managers ability to undertake adaptation planning and action. Understanding these barriers can help managers overcome these challenges before undertaking vulnerability assessment, prioritization, or adaptation planning processes (Moser and Ekstrom 2010). More research is needed to determine how to ensure that 
resources chosen for preservation are representative of diverse histories at regional, national, and potentially international scales. Research and development of new technologies to preserve the research potential of archaeological sites, even without the presence of artifacts, could contribute to cultural heritage preservation in the face of coastal climate change. Policies that reduce the adaptability of budgets, staff time, and historic preservation regulations need to be reconsidered for climate change realities. 


\section{CHAPTER 3: “KEEPING AMERICANS, 'AMERICAN':” NATURAL AND}

\section{CULTURAL EROSION AND THE SHAPING OF COMMEMORATIVE LANDSCAPES IN TIDEWATER VIRGINIA}

In the early 1940s, Colonial Williamsburg published a pamphlet entitled "Preserving the Design for Americans," which claimed that the "restoration of the historic city of Williamsburg to its $18^{\text {th }}$ century appearance is helping to keep Americans, "American." ${ }^{2}$ By this time, Dr. William A.R. Goodwin, with the financial backing of John Rockefeller, Jr., had restored Colonial Williamsburg to wellresearched, $18^{\text {th }}$-century specifications and opened the site to the American public. By visiting the restored colonial capital and viewing the early English architecture, textiles, facades, and furniture that comprised the setting, the pamphlet asserts visitors would gain, or regain, a sense of pride in their American heritage and an understanding of their American identity. Through this pamphlet, Colonial Williamsburg claims that the roots of the American identity are the $17^{\text {th }}$ and $18^{\text {th }}$ century English colonial settlements of Virginia. This statement disregards preceding European settlements in the modern United States, as well as ten-thousand years of Native American history as part of the historical narrative of American origin, asserting both a unified American past and placing Williamsburg at the center of this

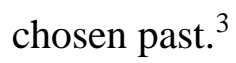

\footnotetext{
2 "Preserving the Design for Americans" (Colonial Williamsburg, N.D.), 1, Box 5, Folder 4, William Pierce Kennedy Papers, Library of Virginia.

${ }^{3}$ Bob Deans, The River Where America Began: A Journey Along the James (Lanham, Maryland:

Rowman \& Littlefield Publishers, Inc., 2007), 57.
} 
Soon after the founding of the United States, the landscape of the Virginia Peninsula became an important symbolic location for the young country. Since the $17^{\text {th }}$ century, the area has retained an agricultural character, interspersed with markers and sites commemorating these events. Virginians constructed the first unofficial monument at Yorktown Battlefield in $1800 .{ }^{4}$ Since then, federal managers including Congress, the Corps, and starting in the 1930s, the National Park Service (NPS), have built, protected, and interpreted Jamestown, Williamsburg, and Yorktown as the birthplace of the American nation, developing recreational spaces and conducting research on the archaeological features in the area.

As federal managers have preserved moments in history through the landscapes at Jamestown and Yorktown, the environment in this area has not provided a stable canvas. Maps from as early as 1673 annotate erosion and change along the shoreline of Jamestown Island and the Virginia Peninsula. ${ }^{5}$ Two centuries later, the Corps and NPS observed and documented changes in the shoreline of the Tidewater region. Overtime, managers have advanced different responses to shoreline erosion corresponding with different preservation priorities and values. At the turn of the $20^{\text {th }}$ century, the Army Corps engineered the shoreline to protect the Jamestown settlement site. By the mid- $20^{\text {th }}$ century, amidst a growing national interest in historic preservation, managers modified the shoreline of Jamestown Island and the landscape of Yorktown Battlefield to represent their 1607 and 1781 appearances. While many national parks have designed landscapes, the commemorative values and themes that

\footnotetext{
${ }^{4}$ Sarah Goldberger, "Seizing the Past: Revolutionary Memory and the Civil War in Yorktown," Virginia Magazine of History \& Biography 122, no. 2 (2014): 97.

${ }^{5}$ Stephen Adams, The Best and Worst Country in the World: Perspectives on the Early Virginia Landscape (Charlottesville, Virginia: University Press of Virginia, 2001), 199.
} 
managers have worked to preserve and present overtime in this 'Birthplace of America' make a statement as to the meaning or origin of what is means to be American. More than the events of the past, managers have focused on the preservation of the landscape and the coastline itself, both to protect the archaeological resources, but also to maintain the perceived character of the area at the time of English settlement. Changes in the cultures, stories, and landscapes that managers work to preserve represent changes in the perception of this facet of American identity.

In the last few decades, anthropogenic climate change has started affecting the Chesapeake Bay area, including the Virginia Peninsula. As sea level rises, the lowlying coastal areas including Jamestown Island and the Yorktown waterfront face faster rates of coastal erosion, inundation, salt water intrusion, and storm impacts, compounded by climate change factors. ${ }^{6}$ Climate change may impact the look of the landscape, as well as the archaeological and historical resources in the area. The National Park Service (NPS) is the primary management agency of the Jamestown and Yorktown areas, encompassed by Colonial National Historical Park (COLO). Interest groups such as Union of Concerned Scientists are framing climate change as a direct assault on the 'Birthplace of America,' calling on the centuries-old, symbolic nature of Jamestown Island, in particular, to spark interest and action in climate change adaptation. $^{7}$

\footnotetext{
${ }^{6}$ G. Ricci et al. (in review), "Colonial National Historical Park Integrated Coastal Climate Change Vulnerability Assessment: A Pilot Method,” Natural Resource Report (Fort Collins, Colorado: National Park Service).

${ }^{7}$ Debra Holtz et al., "National Landmarks at Risk: How Rising Seas, Floods, and Wildfires Are Threatening the United States' Most Cherished Historical Sites" (Union of Concerned Scientists, 2014), 16-17, http://www.ucsusa.org/sites/default/files/legacy/assets/documents/global_warming/NationalLandmarks-at-Risk-Full-Report.pdf.
} 
As national and local park managers work to address the impacts of climate change on COLO cultural landscapes, preservation decisions reflect current perceptions of American identity. As managers interpret and prepare for the projected impacts of climate change, modern values and institutional priorities will continue manifest on this landscape.

Despite the additional challenges from climate change, the coastal erosion remains the driving environmental process behind the deterioration of archaeological sites, historic structures, and cultural landscapes in the James and York River systems. Early managers moved and adjusted their construction around this ongoing erosion; however, since the site has become a commemorative location, managers have elected to hold the coastline in place, both to preserve archaeological resources and the landscape character. Between climate change and limited adaptation resources, managers may no longer be able to control the presentation and location of the shoreline through engineering. As managers preserve and interpret the cultural resources that represent American history on a landscape of climate change, the choices managers make today will impact the preservation and character of the area for future generations. However, a longer history of this landscape shows that preservation values, as well as coastlines, have changed overtime.

\section{Landscape Context: Pre-Contact and Early Colonial Tidewater Virginia}

Tidewater Virginia encompasses the eastern portion of Virginia, bordering the Chesapeake Bay. Numerous rivers, sounds, and swamps divide the land into a series of peninsulas. The Virginia Peninsula is the southernmost of these fingers of land, 
north of modern Norfolk, Virginia and is bounded by the York River to the north and the James River to the south. Within this area, Yorktown, on the York River, Jamestown Island in the James River, and Williamsburg between the two, each hosted, documented, and memorialized now-famous events in early American history. This triangle of sites lies 80-kilometers from the easternmost point of the Virginia Peninsula. Pine and hardwood forests, numerous creeks, streams, and ponds, and tidal and nontidal wetlands define the habitats of the peninsula. ${ }^{8}$ Tidewater Virginia is hot and humid during the summer, with some snowfall during the winter. The tidewater peninsulas are tidal river systems, defined by the ongoing erosion and accretion of sediment along the peninsulas. Major hurricanes strike the area approximately once per decade, hurricanes approximately twice per decade, and tropical storms approximately once per year, contributing to the ongoing shoreline erosion. ${ }^{9}$

\footnotetext{
${ }^{8}$ Norfolk District, U.S. Army Corps of Engineers, "Shoreline Management Plan Colonial National Historical Park Jamestown Island, Virginia" (Norfolk, Virginia: Army Corps of Engineers, April 2002). ${ }^{9}$ C.J. Schreck III, K.R. Knapp, and J.P. Kossin, "The Impact of Best Track Discrepancies on Global Tropical Cyclone Climatologies Using IBTrACS,” Monthly Weather Review 142 (2014): 3881-99, https://doi.org/10.1175/MWR-D-14-00021.1; Robert L. Steenhagen et al., "A Master Plan for Colonial National Historical Park" (National Park Service, 1971), 26, Record Group 79, Division of Interpretive Planning, Records of Public Input Documenting Interpretive Planning Activities, 1955-1999, Box 59, National Archives, College Park, Maryland.
} 


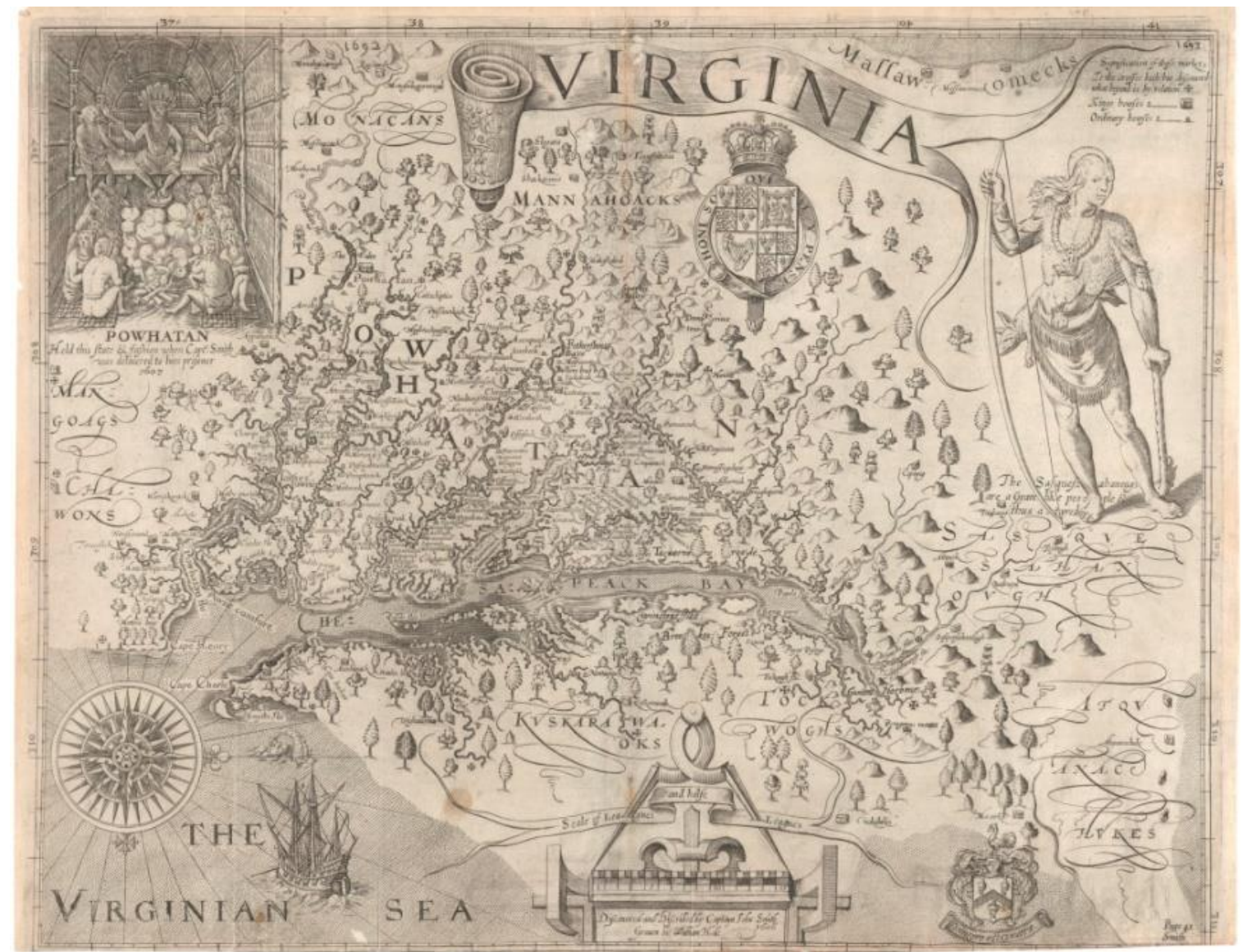

Figure 1. John Smith's 1606 map of Virginia. ${ }^{10}$

Native Americans managed the Virginia Peninsula since at least 9500BCE, with some of the oldest evidence of occupation coming from the area just south of the James River. ${ }^{11}$ Historian Stephen Adams expresses concerns about discussing the perspectives of Native American managers on the Virginia landscape because perceptions include sensory inputs and these may be culturally relevant to the experience of the observer. ${ }^{12}$ Existing records indicate that tribes in coastal Virginia outlined time by a lunar cycle, and named time frames according to the weather and

\footnotetext{
${ }^{10}$ John Smith, Virginia Discovered and Described by Captayn John Smith, 1606, Engraven by William Hole, 1624, Archives Research Services Map Collection, A5 Voorhees Collection, G3880, Library of Virginia.

${ }^{11}$ Stephen Adams, The Best and Worst Country in the World: Perspectives on the Early Virginia Landscape (Charlottesville, Virginia: University Press of Virginia, 2001), 28.

12 Ibid., 30.
} 
harvest conditions. ${ }^{13}$ Oral recollections suggest that storms were framed as sentient, and could be convinced to leave the area. ${ }^{14}$ During the early $17^{\text {th }}$ century, Powhatan led a 30-tribe unit in of Algonquian villages in and around the Virginia peninsula, with each village consisting of approximately ten structures built on burned and cleared land. ${ }^{15}$

However, rather than perceiving a coastal landscape manipulated by human hands, early British settlers saw the landscape as both a wild to be tamed and a set of resources to contribute to a broader global system of trade centered. Early European accounts of Virginia generously describe an Eden and focus on either commodities that might encourage investment because they are lacking in Europe or commodities that could help to sustain a colony, such as lumber and fish. ${ }^{16}$ Historian Karen Kupperman argues that the settlers believed that by organizing and arranging spaces in the New World into familiar, European agricultural systems, settlers believed the climate itself would also become more temperate; they could tame the wilderness as well as the harsh weather. ${ }^{17}$ However, labor shortages from disease, both in the European and Native American populations affected settler's ability to implement their ideas. To address this issue, English settlers began to import indentured servants

\footnotetext{
13 Ibid., 38.

14 Ibid., 41.

${ }^{15}$ Mary K. Geiter and W.A. Speck, Colonial America from Jamestown to Yorktown, American History in Depth (New York City, New York: Palgrave MacMillan, 2002); Adams, The Best and Worst Country in the World: Perspectives on the Early Virginia Landscape, 35.

${ }^{16}$ Edward E. Hale, ed., "Ralph Lane to Sir Francis Walsingham, 12th August 1585," in Original Documents from the State-Paper Office, London, and the British Museum; Illustrating the History of Sir Walter Raleigh's First American Colony and the Colony at Jamestown. With an Appendix Containing a Memoir of Sir Ralph Land, The Governor of the Colony of Roanoke (Boston, Massachusetts: John Wilson and Son, 1860); William Cronon, Changes in the Land: Indians, Colonists, and the Ecology of New England (New York City, New York: Hill and Wang, 2003).

${ }^{17}$ Karen Ordahl Kupperman, "The Puzzle of the American Climate in the Early Colonial Period," The American Historical Review 87, no. 5 (December 1982): 1262-89.
} 
and African slaves. ${ }^{18}$ From the early colonial period, English settlers organized the environment around a perceived ideal and constructed this environment as supplies, resources, and coastal processes would allow.

After early environmental hardship caused both by a drought as well as the settler's environmental unfamiliarity and misplaced priorities, in 1619 settlers formed the Jamestown democratic body. ${ }^{19}$ This body met yearly to establish, regulate, and update rules of the colony. Some of the regulations of this governmental body focused on changes in the Virginia environment. The first approvals for the draining of coastal marshes in Virginia passed as early as $1672 .{ }^{20}$ As Jamestown transitioned from a company to crown-owned colony, new settlers purchased land, women emigrated to the area, and the population grew. ${ }^{21}$ New English arrivals to Jamestown increasingly came into conflict with Native Americans, as settlers purchased agricultural plots that began to sprawl onto more land area on the Virginia Peninsula. Starting in 1621, settlers mapped streets, built a town, and settled in New Town adjacent to James Fort. They expanded to Williamsburg, settling there in 1632 and in Yorktown in 1691.

As English settlers took over larger areas of land on the Virginia Peninsula, their agricultural and residential development began to alter the ecological assemblages of the Peninsula. Longleaf pine populations declined and loblolly pine

\footnotetext{
${ }^{18}$ Ibid., 188-98; Deans, The River Where America Began: A Journey Along the James, 117. The first African person in the colony arrived in 1619 aboard White Lion.

${ }^{19}$ Dennis B. Blanton, "The Weather Is Fine, Wish You Were Here, Because I'm the Last One Alive: 'Learning' the Environment in the English New World Colonies," in Colonization of Unfamiliar Landscapes: The Archaeology of Adaptation (London: Routledge, 2003), 190.

${ }^{20}$ Yasuhide Kawashima and Ruth Tone, "Environmental Policy in Early America: A Survey of Colonial Statues," Journal of Forest History, October 1983, 168-79.

${ }^{21}$ Geiter and Speck, Colonial America from Jamestown to Yorktown.
} 
grew in the wake. ${ }^{22}$ Governor William Berkeley aimed to make the colony less dependent on tobacco, importing mulberry trees and trying to grow silk worms in the area. ${ }^{23}$ Settlers used construction techniques tailored to the Virginia environment, with the first residents in New Town including depressions in the bricks around their house foundations to help guide water away from the walls. ${ }^{24}$ With plentiful land, settlers built large, low houses for summer ventilation. ${ }^{25}$ However, the early settlement was plagued by intense storms. In 1667, a hurricane caused the loss of woods, cattle and crops. ${ }^{26}$ A comparison with the 1670 map of Virginia completed by Augustine Herrman shows a continual change in the shape of the shoreline due to winter storms and summer hurricanes. ${ }^{27}$ These observations, construction techniques, and maps show that colonists responded to environmental changes by adjusting their construction and engineering techniques.

As the natural changes from coastal erosion, as well as the man-made changes from tobacco crops leaching soils and fires in the structures affected the early colonial settlement, managers responded to these changes by relocating or rebuilding structures

${ }^{22}$ Adams, The Best and Worst Country in the World: Perspectives on the Early Virginia Landscape, 227.

${ }^{23}$ Geiter and Speck, Colonial America from Jamestown to Yorktown.

${ }^{24}$ Philip N. Stern, “Architectural Remains, Unit A, Sub-Unit 39, Jamestown Island, Virginia” (Historic American Buildings Survey, n.d.), Historic American Buildings Survey, Virginia, Volume 122, Library of Congress, Washington, D.C.

${ }^{25}$ Robert Beverly, "Virginia," in The Colonial Image: Origins of American Culture, ed. John C. Miller and Louis B. Wright (New York City, New York: George Braziller, 1962), 295. Written in 1705 and republished as an excerpt in 1962 by Miller and Wright, Robert Beverly was born in Jamestown in 1667. As an early observer and historian of the Virginia Colony, he commented on the structures in Williamsburg, "The Private Buildings are of late very much improved; several Gentleman there, having built themselves large Brick Houses of many Rooms on a Floor, and several Stories high, as also some Stone-Houses: but they don't covet to make them lofty, having extent enough of Ground to build upon; and now and then they are visited by high Winds, which wou'd incommode atowering Fabrick. The always contrive to have large Rooms, that they may be cool in Summer."

${ }^{26}$ Adams, The Best and Worst Country in the World: Perspectives on the Early Virginia Landscape, 198.

27 T.H. Breen and Stephen Innes, “Myne Own Ground”: Race and Freedom on Virginia's Eastern Shore, 1640-1676, 25th Anniversary Edition (New York City, New York: Oxford University Press, $2005), 37$. 
and fortifications. During the late $16^{\text {th }}$ and early $17^{\text {th }}$ centuries, British officials built batteries at Gloucester Point and Yorktown; however, the batteries eroded due to wave action and in 1736, British officials moved the Yorktown battery from the beach to the bluffs to prevent further erosion. ${ }^{28}$ In 1699 , the legislature voted to leave Jamestown in favor of Williamsburg both due to a destructive fire in Jamestown and because the population growth of inland Virginia made Williamsburg a more central location.

With the move to Williamsburg, the port city of Yorktown grew in importance. Yorktown had a deep harbor and tidewater plantation owners shipped tobacco crops to the small port, where they could be transferred to larger, ocean-going vessels. ${ }^{29}$ Merchant families built wharves and warehouses along the Yorktown waterfront to support their businesses. ${ }^{30}$ As tobacco leached the soil, farmers moved west for more land and instead transported their products on the longer James River, causing a decline in maritime Yorktown, growth of Richmond, on the James River, and soon, dredging on the James River to enhance commerce. ${ }^{31}$

During the American Revolution and the following century, colonial and British troops, the Continental Congress, and later the United States government made physical changes to the landscape and riverways in order to further military and commercial goals. During the American Revolution, Williamsburg was too easily accessible by sea and in 1779 , Virginians moved their capital to Richmond. ${ }^{32}$ Despite this move, the James River provided access for British forces to attack Richmond. The

\footnotetext{
${ }^{28}$ Edward M. Riley, "Suburban Development of Yorktown, Virginia, during the Colonial Period," The Virginia Magazine of History and Biography 60, no. 4 (October 1952): 522-36.

${ }^{29}$ Deans, The River Where America Began: A Journey Along the James, 167.

${ }^{30}$ Riley, "Suburban Development of Yorktown, Virginia, during the Colonial Period," 528.

${ }^{31}$ Ibid., 535-36.

${ }^{32}$ Deans, The River Where America Began: A Journey Along the James, 209.
} 
riverine setting of this area also motivated Cornwallis to select the location, where his entrapment eventually led to the surrender of British troops. ${ }^{33}$ For the remainder of the $19^{\text {th }}$ century, Jamestown, Williamsburg and Yorktown remained quiet towns on the Virginia Peninsula. British troops burned Yorktown during the War of 1812, and the three areas decreased in importance as the country expanded westward. ${ }^{34}$ Congress approved various projects to improve the ease of navigation to Richmond, by way of the James River, deepening the channel to 17 feet and removing many shoals upstream from Jamestown Island. ${ }^{35}$

During and after the Civil War, military and government forces carved trenches, built bridges, and dredged rivers creating environmental change to further military and commercial priorities. These changes were not unique to the James and York rivers and coastlines, but were taking place on waterways around the country. ${ }^{36}$ During the Civil War, the Virginia Peninsula was the location of the Peninsula Campaign given the access to Richmond using the James River. ${ }^{37}$ Union troops built bridges in the swampy areas surrounding the Chickahominy River, north of Jamestown and Yorktown. ${ }^{38}$ The Battle of Williamsburg changed the topography of the area as soldiers carved additional trenches and adapted existing trenches from the

\footnotetext{
${ }^{33}$ Ibid., 214.

${ }^{34}$ Mrs. Sydney Smith, “Old Yorktown and Its History” (Colonial Williamsburg, 1920), Box 5, Folder 4, William Pierce Kennedy Papers, Library of Virginia.

${ }^{35}$ Secretary of War, "Survey of the James River," Pub. L. No. H.Doc. 133, § Committee on Commerce, 1 (1837).

${ }^{36}$ Michael Rawson, "What Lies Beneath: Science, Nature, and the Making of Boston Harbor," Journal of Urban History 35, no. 5 (July 2009): 675-97.

${ }^{37}$ Stephen W. Sears, To the Gates of Richmond: The Peninsula Campaign (New York City, New York: Ticknor \& Fields, 1992), 48.

${ }^{38}$ Kathryn Shively Meier, Nature's Civil War: Common Soldiers and the Environment in 1862 Virginia (Chapel Hill, North Carolina: The University of North Carolina Press, 2013), 44.
} 
Revolutionary War. After the Civil War, the Corps dredged the waterways bordering the Virginia Peninsula to support navigation and commerce.

The Corps calculated the need and depth for dredging projects based on the expected longevity of the project given the bottom sediment conditions and the value and number of beneficiaries from the increased commercial activity in the area. ${ }^{39}$ Congress authorized a lighthouse on Bell's Rock Bar and in 1894 introduced a bill to provide lights on the York River, improving the safety of commercial activities in the area. ${ }^{40}$ On the James River, Congress continued to remove rock formations and sunken Civil War vessels near Richmond to encourage commerce in the area ${ }^{41} \mathrm{~A}$ subsequent Army Corps report on dredge projects in the area labeled the James River as a very changeable system, identifying Goose Hill as a landform that may have once been a part of Jamestown Island. ${ }^{42}$ Despite this recognition of long term change, by the end of the $19^{\text {th }}$ century, federal managers would define and attempt to recreate an "original" shoreline of Jamestown Island and land cover of Yorktown Battlefield.

\section{Developing the Historic Triangle as a Commemorative Landscape}

Collectively known as the historic triangle, Jamestown Island, Williamsburg, and Yorktown, hosted the first English democratic governmental body, the first permanent English settlement, the first African slave in the United States, and a key

\footnotetext{
${ }^{39}$ Secretary of War, "Copy of Report of Capt. C.B. Phillips, Corps of Engineers, of Surveys of York River, and of Lynn Haven, Link Horn, and Broad Bays, Virginia," § Committee on Commerce (1880). ${ }^{40}$ Beale, "Light-House on Bell's Rock," § Committee on Commerce (1880); Wise, "Port Lights on York River, Virginia," § Committee on Interstate and Foreign Commerce (1894).

${ }^{41}$ Secretary of War, "Engineer's Report of Certain Rivers and Harbors," Pub. L. No. H.Exec.Doc. 60 Pt. 1, § Committee on Commerce, 1 (1871). Secretary of War, "Survey of the James River, VA," Pub. L. No. S.Exec.Doc. 147, § Committee on Commerce, 1 (1882).

${ }^{42}$ Ibid. Additionally, they decide that it may be advisable to drill deeper now rather than undertake the process again as technology progresses.
} 
battle at the end of the American Revolution. In memorializing these events, the managers of the Virginia Peninsula responded to and created environmental change inline with their priorities for the creation of a landscape to commemorate events in early American history and unify the country around a national story. Managers built commemorative installations and made changes to the James and York rivers and shorelines to protect the archaeological sites on Jamestown Island and enhance commercial activity in the area. The Corps viewed environmental changes wrought by storms and coastal erosion in the area as a potential threat to the monuments and sites and prepared for these changes by fortifying monuments and constructing seawalls. Not only the places, but the renderings and descriptions of changes such as Jamestown ruins and the addition of a monument at Yorktown Battlefield had symbolic value, emphasizing the growth and development of the American nation since the $17^{\text {th }}$ century.

Virginians first went to Congress to request a commemorative marker at Yorktown Battlefield in 1781. Congress approved the request, but construction on the Yorktown Victory Monument would not begin for a century. In the meantime, Virginians began erecting their own commemorative structures to designate Yorktown Battlefield, the first of which planted in 1800 with a stand of four poplar trees surrounding a small coffin to honor the aging early American leaders. ${ }^{43}$ In 1824, the Marquis de Lafayette visited Yorktown Battlefield, where he had led troops against British General Cornwallis during the American Revolution. Temporary obelisks were

\footnotetext{
${ }^{43}$ Goldberger, "Seizing the Past: Revolutionary Memory and the Civil War in Yorktown."
} 
erected for the event. ${ }^{44}$ Yorktown citizens again requested a monument from Congress in 1834,1836 and 1838 , but none was forthcoming. ${ }^{45}$ Leading up to the Civil War, New Englanders and Southerners were divided over Jamestown or Plymouth as the origin of America. ${ }^{46}$ The Virginia militia laid the cornerstone for a monument to American victory at Yorktown in 1860; however, Confederate troops removed the cornerstone to prevent it from becoming subject to the interpretation of Union troops. $^{47}$

During the Peninsula Campaign, both Union and Confederate troops anticipated a regal site to represent the symbolic meaning of Yorktown contributed to both Union and Confederate expectations was not lost on Union and Confederate troops in the area. Yorktown Battlefield represented a decisive victory for the colonial forces in the American Revolution, and historian Sarah Goldberger argues that this symbolism influenced the expectations of both Union and Confederate troops. ${ }^{48}$ However, the Civil War action in the area was neither decisive nor did it match the symbolic vision of the troops. ${ }^{49}$ Following the divisiveness of the Civil War, the American public, nostalgic for the unity and patriotism the Revolutionary War had come to represent, became increasingly interested in honoring and memorializing

\footnotetext{
${ }^{44}$ John Foster, A Sketch of the Tour of the General Lafayette, on His Late Visit to the United States (Portland, Maine: A.W. Thayer, 1824), 208; Thomas A. Chambers, Memories of War: Visiting Battlegrounds and Bonefields in the Early American Republic (Ithaca, New York: Cornell University Press, 2012), 65-66.

${ }^{45}$ Wise, "Monument at York, in Virginia" (1834).

${ }^{46}$ David Waldstreicher, In the Midst of Perpetual Fetes: The Making of American Nationalism, 17761820 (Chapel Hill, North Carolina: University of North Carolina Press for the Omohundro Institute of Early American Culture, 1997), 267-69.

${ }^{47}$ Ibid., 181.

${ }^{48}$ Goldberger, "Seizing the Past: Revolutionary Memory and the Civil War in Yorktown."

${ }^{49}$ Ibid.
} 
spaces and relics of colonial history and made changes to the landscape to further this goal.

Yorktown Battlefield became a key symbol of this desire for national unity. In 1881, a century after Congress authorized a monument at the site, the Free Masons laid the cornerstone of the Yorktown Victory Monument. The monument would stand at an overlook of the York River, in full view of passing vessels. ${ }^{50}$ In his speech at the cornerstone ceremony, Governor of Virginia and a former Confederate army officer and congressman, Frederick W.M. Holliday, further emphasized national unity by emphasizing the wilderness that molded and shaped American men and the "triumph of law," represented by the Yorktown Victory Monument. Skillfully skipping the intermediate period in American history, Governor Holliday looked to the future, again using the American environment to emphasize unity. He argued that while "Nature often has been too powerful for man, and has held him in check, or subjection, by the obstacles it has presented to his progress..." ${ }^{\text {51 }}$ but the American nation had grown from disorganized troops at Yorktown to a populous nation of men who were conquering the American west. Three years later, architect Henry Brunt and sculptor J. Ward completed their work on the Yorktown Victory Monument. Asserting their scientific and engineering identity, the Corps calculated the wind velocity the monument would need to withstand from wind velocity measurements taken during a storm at the nearby Cape Fear and approved the installation, committing one army

\footnotetext{
50 “A Joint Resolution of Congress, Providing for the Erection of a Monument at Yorktown, VA. Commemorative of the Surrender of Lord Cornwallis," Pub. L. No. S.Rpt. 1003 (1883); National Park Service, "Yorktown Victory Monument," Yorktown Battlefield, Part of Colonial National Historical Park, August 21, 2015, https://www.nps.gov/york/learn/historyculture/vicmon.htm.

51 "A Joint Resolution of Congress, Providing for the Erection of a Monument at Yorktown, VA. Commemorative of the Surrender of Lord Cornwallis,” Pub. L. No. S.Rpt. 1003 (1883), 21.
} 
enlist to serve as the guard of the monument. ${ }^{52}$ However, the Corps spent little time maintaining the keeper's quarters and by 1886 , the quarters had deteriorated. ${ }^{53}$

Following the installation of the Yorktown Victory Monument, in 1893, the Association for the Preservation of Virginia Antiquities, acquired the Jamestown Island site of the first permanent English settlement. The goal of this organization was to protect and preserve the heritage of Virginia, including both the symbolic meaning and tangible artifacts at the site. ${ }^{54}$ Later, a Virginia newspaper would refer to this purchase by the Association for the Preservation of Virginia as "rescuing" Jamestown "from the disastrous effects of fires, floods, and the hand of time and tourists." 55 Between 1894 and 1901, the Corps constructed a 1,500-meter seawall along the shore of the location of the earliest English inhabitation of Jamestown Island, showing a federal interest in protecting and preserving this Jamestown settlement site. This initial installation cost $\$ 25,000$. After this initial installation, the State of Virginia appropriated another $\$ 15,000$ and asked the Army Corps to oversee "the extension and completion of the sea wall and the construction of any other necessary works for protecting Jamestown Island, in the State of Virginia, from the encroachments of James River." 56 The State of Virginia wanted to protect a longer expanse of the Jamestown shoreline from erosion. The Army Corps; however, asserted that "the protection of this island cannot be said to be necessary to the improvement or

\footnotetext{
52 "Papers Relative to the Completion of the Monument of Yorktown" (1885).

${ }^{53}$ Secretary of War, "Provision for Quarters for Keeper of Yorktown Monument" (1886).

54 Jamestown Rediscovery, "History of Preservation Virginia," accessed August 8, 2017, http://historicjamestowne.org/about/history-of-apva/.

55 “The Lee Family Remembers," Richmond Times-Dispatch, N.D., Box 99, Folder 1, Virginia Department of Conservation \& Recreation, Division of History, Library of Virginia.

${ }^{56}$ Chief of Engineers, "Annual Report of the Chief of Engineers to the Secretary of War for the Year 1904 " (1904), 216.
} 
conservation of the navigation of James River." ${ }^{\circ 7}$ This early discrepancy in priorities and conservation needs would foreshadow later disagreements between preservationoriented APVA, and later NPS, and the navigation and commerce-focused Army Corps.

Already a commemorative site at the turn of the $20^{\text {th }}$ century, the Jamestown Exposition in 1907 refined and emphasized the status of Jamestown Island as the 'birthplace of the nation.' Hampton Roads, in Norfolk, Virginia, 50-kilometers southeast of Jamestown Island on the James River, won the bid to host the 1907 Jamestown Exposition. In preparation for the exposition, Congress provided $\$ 65,000$ for dredging at Hampton Roads and additional funding for the construction of structures and facilities, including $\$ 400,000$ for a set of parallel piers with protected berths in the center. ${ }^{58}$ Three-hundred years after English settlers landed at Jamestown Island, the exposition advertised American commercial development in Norfolk and introduced American manufacturers to world markets. ${ }^{59}$ Although the $300^{\text {th }}$ anniversary of the English landing at Jamestown was the cause for celebration, due to confusion over landing permissions and borrowing existing wharfs, the planned landing pier to allow exposition visitors access to Jamestown Island was never built. ${ }^{60}$ While the natural setting of Jamestown Island served a symbolic role for the event, the physical environment of the island was not on display.

\footnotetext{
57 Chief of Engineers, 216.

${ }^{58}$ Secretary of the Treasury, "Additional Appropriation for Piers, Hampton Roads, Jamestown Exposition," § Committee on Appropriations (1906).

${ }^{59}$ Carl Abbott, "Norfolk in the New Century: The Jamestown Exposition and Urban Boosterism," The Virginia Magazine of History and Biography 85, no. 1 (January 1977): 94-95.

${ }^{60}$ Maynard, "Jamestown Exposition,” § Committee on Industrial Arts (1906).
} 


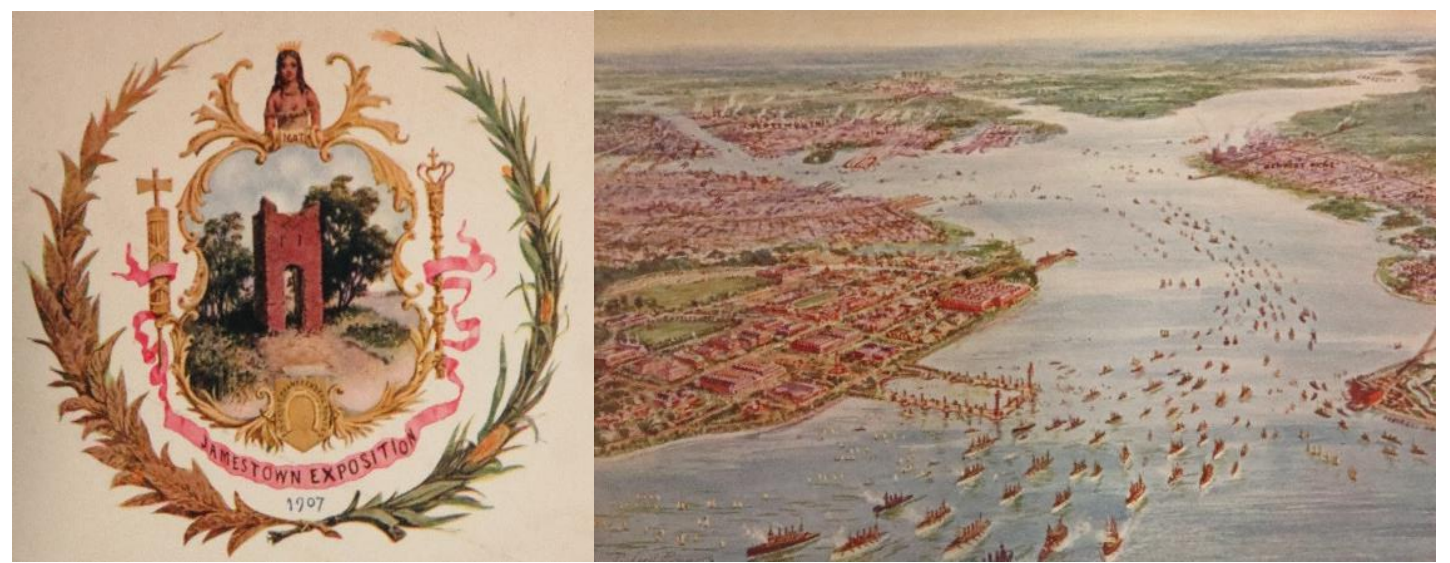

Figure 2. Official seal of the Jamestown Exposition of 1907 (left) and a modern fleet entering Hampton Roads during the exposition (right).

The Jamestown Exposition of 1907 cemented the Virginia Peninsula as a commemorative landscape, and the birthplace of America; however, the transformation America had undergone since this birth was the more important message. ${ }^{61}$ Conspicuously named after the location that claimed to be the start of the nation, yet hosted in a modern port city, the Jamestown Exposition, displayed American Naval prowess with a goodwill appearance by the Great White Fleet, showcased American industry, and emphasized the development of both by contrasting them with the historic Jamestown landscape. Postcards at the exposition depicted romanticized scenes of John Smith's encounter with Pocahontas and the conversion of the Powhatan people by English settlers, tying American history to both Christianity and European ancestry. Other images from the exposition showed the ruins of the church tower on Jamestown Island. The juxtaposition of new, modern structures at Hampton Roads and historic brick ruins at Jamestown Island, the place

\footnotetext{
${ }^{61}$ Secretary of the Treasury, "Transportation of Troops, Jamestown Exposition," Pub. L. No. H. Doc. 302, § Committee on Appropriations, 1 (1906); Hale, "Harbor Accommodations for Vessels," Pub. L. No. S.Doc. 168, § Committee on Naval Affairs, 1 (1907).
} 
where the country began, emphasized the long history of the country, displaying the United States as a developed, established country.

Around the time of the Jamestown Exposition, national expectations of historic preservation were changing. The Antiquities Act of 1906 allowed the president to declare historic landmarks and permit qualified agencies to carry out archaeological investigations thereof. Ten years later, the Organic Act created and authorized the National Park Service to "conserve the scenery and the natural and historic objects and the wildlife therein and provide for the enjoyment of the same in such manner and by such means as will leave them unimpaired for future generations." ${ }^{2}$ The shift from management by the Corps to the preservation-minded NPS, represents a broader change in American policy which was beginning to play out in the physical designs of new national monuments and parks. In his classic volumes, Preservation Comes of Age, Hosmer Jr. traces the start of American historical preservation to the feeling post World War I that the United States was changing rapidly. Amidst the fear that technological development and modernity would make the lives of parents and grandparents unrecognizable to younger generations, early historic preservation work aimed to preserve past ways of life, modernity and technology made these sites accessible. ${ }^{63}$ After World War I, the Committee on Public Lands argued that the American people were losing key historic sites in the area of American "firsts," Jamestown, Yorktown, and Williamsburg, and to combat this loss, endorsed the

\footnotetext{
${ }^{62}$ United States Congress, “Organic Act,” Pub. L. No. 91-458, § 1, 39 Stat. 5316 U.S.C. 1 (1916).

${ }^{63}$ Charles B. Hosmer, Jr., Preservation Comes of Age: From Williamsburg to the National Trust, 19261949, vol. I (Charlottesville, Virginia: University of Virginia Press, 1981).
} 
creation of Colonial National Monument. ${ }^{64}$ On July $3^{\text {rd }}, 1930$, Congress designated

Colonial National Monument, Yorktown Battlefield, newly designated as one of the most significant battlefields in America, became a key site in the newest national monument. ${ }^{65}$

\section{Constructing a Modern Park for a Modern America}

With a growing American interest in historical preservation and historic sites, as management of the Historic Triangle shifted from the Corps to NPS, the new managers would respond to environmental changes by further altering the environment with the intention of minimizing erosion and creating a clean, streamlined setting that contemporary audiences would recognize as a historic park. In updating and improving the settings of Jamestown and Yorktown, the managers of the Virginia Peninsula responded to and created environmental change in line with the design priorities of building a commemorative landscape. As earlier managers used the park to emphasize national unity at the time of the American Revolution during post-Civil War strife, NPS managers in the early $20^{\text {th }}$ century strove to present a

\footnotetext{
${ }^{64}$ Colton, To Provide for the Creation of the Colonial National Monument in the Commonwealth of Virginia.

${ }^{65}$ Wadsworth, "Study and Investigation of the Battlefields in the United States for Commemorative Purposes, (4. In this study, Wadsworth the battlefield classes as: "Class I. Battles worthy of commemoration by the establishment of national military parks. These should be battles of exceptional political and military importance and interest whose effects were far-reaching, whose fields are worthy of preservation for detailed military and historical study, and which are suitable to serve as memorials to the armies engaged. Class II. Battles of sufficient importance to warrant the designation of their sites as national monuments. The action of Congress and the great difference in the importance of these battles give reason for the subdivision under this class into: Class IIa. Battles of such great military and historic interest as to warrant locating and indicating the battle lines of the forces engaged by a series of markers or tablets, but not necessarily by memorial monuments. Class IIb. Battles of sufficient historic interest to be worthy of some form of monument, tablet, or marker to indicate the location of the battle field."
} 
chosen past through the design of the site and the restoration of historic structures to a period deemed most significant.

This new focus on restoration and recreation represented both a changing perspective on the environment and physical changes made to the place. Fires and wartime destruction have continuously remodeled and repurposed homes and other buildings in this area. ${ }^{66}$ In the 1920 s, Williamsburg, within Colonial National Monument, became the restoration project of Rev. W.A.R. Goodwin and John Rockefeller, Jr. who intended to restore and rebuilt Williamsburg as the colonial capital it once was. Rockefeller restored Colonial Williamsburg because the American landscape was quickly changing and his family had played a disproportionate role in the transformation. Colonial Williamsburg set a new standard in the practice of historic preservation. ${ }^{67}$ Throughout the 1930s, various parties lobbied to include Green Springs Plantation, Moore House, Roswell House, Cape Henry, the Hook area, and additional acreage at Yorktown Battlefield within the purview of Colonial National Monument. ${ }^{68}$ In 1936, Colonial National Monument became Colonial National Historical Park (COLO). The Secretary of War gave Cape Henry to the park, under the condition that the military could reclaim the area at any time the "paramount needs of national defense," ${ }^{69}$ arose, identifying historic preservation as a trivial project compared with military shoreline uses. As COLO grew against the background of an

\footnotetext{
${ }^{66}$ Smith, "Old Yorktown and Its History."

${ }^{67}$ Charles B. Hosmer, Jr., Preservation Comes of Age: From Williamsburg to the National Trust, 19261949, vol. I (Charlottesville, Virginia: University of Virginia Press, 1981).

${ }^{68}$ Robinson, "Colonial National Monument in the State of Virginia," § Committee on Public Lands (1935); Adams, "Cape Henry Memorial, Fort Story, Virginia," § Committee on Public Lands and Surveys (1938); Adams, "Colonial National Historical Park, VA,” § Committee on Public Lands and Surveys (1938); DeRouen, "Revising the Boundaries of the Colonial National Historical Park in the State of Virginia," § Committee on Public Lands (1938).

${ }^{69}$ Adams, Cape Henry Memorial, Fort Story, Virginia.
} 
increasing national interest in historic preservation and adjacent to the Colonial Williamsburg project, the park too tried to recreate historic pasts. However, at Colonial National Historical Park, restoration would focus on the reconstruction of a place rather than a structure.

The authenticity of Colonial National Park came from visitors' ability to imagine they were walking in the same place as the English settlers or of the Revolutionary War soldiers. From the beginning, COLO was established because of the importance of place, aided by the seemingly minimal change in the dominant local industries and landscapes overtime. In Here, Washington Was Born, historian Seth Bruggeman traces the commemorative history of the George Washington birthplace, 100-kilometers north of COLO, on the northernmost of the Virginia Tidewater peninsulas. Much like COLO, George Washington's Birthplace National Monument has a long commemorative history starting with the monument laid at the site by George Washington's step-grandson, George Washington Parke Custis in 1815. Bruggeman argues that Custis and others who sought recognition and legitimacy for George Washington's Birthplace as a site did so with the idea that "healthy homes bred strong character in our nation's heroes." ${ }^{70}$ Later managers as well would recreate these characteristics in order to inspire and teach new generations to maintain strong character. While Colonial National Park was never a house museum, Governor Holliday alluded to a similar idea in his speech in 1881, at Yorktown: the Virginia environment made American men.

\footnotetext{
${ }^{70}$ Seth C. Bruggeman, George Washington Birthplace National Monument: Administrative History 1930-2000 (U.S. Department of the Interior, National Park Service, 2006), 63.
} 
In this park, this notion of commemoration manifest in the study of the archaeological remains and shape of the physical environment. Under the management of NPS, archaeological preservation "in perpetuity," as well as archaeological research, became an early focus of the site. As planning for Colonial National Monument got underway, monument superintendent along with two assistant monument historians started a publication entitled Historical Notes: Colonial National Monument. The aim of this publication was "to present in each number a studied discussion of some historical subject." ${ }^{71}$ The resulting publication described the people and architectural features that the park would memorialize, providing timelines of Jamestown, Williamsburg, and Yorktown from the early $17^{\text {th }}$ century until 1781 , outlining where managers would focus their restoration and interpretation attention. In the third volume, Monument Ranger and Naturalist Gerard Banks describes the geologic history of the James and York River, discussing the continuing erosion of shells, fossils, sand and earth from the Yorktown Cliffs. Ranger Banks explains that the process of sediment erosion is still operating today along the James and York River banks; however, he does not discuss this process as a threat to the human history of the area.

The subsequent design of the park by the Director of the National Park Service, COLO architects, and others were aware of ongoing environmental change and would design and modify the monument landscape in response to the environmental erosion at the site. In addition to environmental erosion, in a press release from November 1930, Horace Albright, Director of the National Park Service

\footnotetext{
${ }^{71}$ William M. Robinson, Jr., Elbert Cox, and B. Floyd Flickinger, "Historical Notes, Volume I, No. 1," February 1932, Record Group 79, Nature Notes, 1927-1935, Box 2, National Archives, College Park, Maryland.
} 
emphasized the role of the park in "realizing that as time went on interest in our colonial history would increase, and that at the same time the historic arena would gradually lose their identity unless protected in some way against the march of modernism, took steps toward giving national protection to three famous colonial areas in Virginia..."72 Preserving Jamestown, Williamsburg and Yorktown was a fight against the erosion of the shoreline, the erosion of colonial history, and the erosion of American identity. To preserve the colonial environment of these areas, park managers began planning a program of restoration of shoreline and landscape to an earlier period. Chief Landscape Architect of Colonial National Monument, Thomas Vint defined the period to memorialize in Yorktown as 1781, the year of Cornwallis' surrender. $^{73}$

While park managers fought against the natural change of the shoreline, they also reasserted perceived original shorelines through engineering and modification of the shoreline. To connect the sites in Colonial National Monument with the year of Cornwallis' surrender, monument landscape architects planned to remove modern structures from Gloucester Point, reconstruct 60 historic houses, and install historic facades to disguise buildings with modern uses. ${ }^{74}$ planned to build bridges in the park to give a colonial feel, even though they were unable to find examples of colonial

\footnotetext{
${ }^{72}$ Horace Albright, "For Release Tuesday Morning Newspapers" (National Press, November 11, 1930), Record Group 79 Records of the National Park Service, Classified Files, 1927-1931, Box 53, National Archives, College Park, Maryland.

${ }^{73}$ Thomas Vint, "Memorandum for the Director Regarding the Development of Yorktown," March 28, 1931, Record Group 79 Records of the National Park Service, Classified Files, 1927-1931, Box 53, National Archives, College Park, Maryland.

${ }^{74}$ Charles E. Peterson, "Peterson to the Director," December 14, 1931, Record Group 79 Records of the National Park Service, Classified Files, 1927-1931, Box 53, National Archives, College Park, Maryland; Vint, "Memorandum for the Director Regarding the Development of Yorktown."
} 
bridge design. ${ }^{75}$ Peterson gave directions to prepare the grounds in the colonial style and spend any remaining funds to "to hire common labor to dig exploratory trenches to recover whatever archaeological evidence remains." ${ }^{, 76}$ As monument managers continued to design the area and prepare for the Yorktown Sesquicentennial of 1931, they added roads and trails to the Yorktown area of the monument, repaired pipes and culverts in order to "obviate unsightly ditches," designed walls to make sure quarters at the Naval Weapons Station were not visible from the park, and insured viewsheds to the York River were clear. ${ }^{77}$ Peterson oversaw the removal of additions to the Moore House that post-dated $1781 .^{78}$ Gasoline stations were placed in locations on the parkway which would not detract from the viewshed. ${ }^{79}$

While Vint and Peterson removed 150 years of social change from Yorktown, at Jamestown, they determined the restoration to the 1607 date required the recreation of the shoreline to its early $17^{\text {th }}$ century location. In a memorandum to the Director of the National Park Service in May 1931, the Assistant Landscape Architect of the

\footnotetext{
${ }^{75}$ Charles E. Peterson, "Petersen to Whitehead," March 31, 1931, Record Group 79 Records of the National Park Service, Classified Files, 1927-1931, Box 53, National Archives, College Park, Maryland.

${ }^{76}$ Charles E. Peterson, "Peterson to Robinson," October 27, 1931, Record Group 79 Records of the National Park Service, Classified Files, 1927-1931, Box 53, National Archives, College Park, Maryland.

77 "Release for Morning Papers of October 12, 1931" (National Press, October 12, 1931), Record Group 79 Records of the National Park Service, Classified Files, 1927-1931, Box 53, National Archives, College Park, Maryland; Charles E. Peterson, "Peterson to Spelman," August 11, 1931, Record Group 79 Records of the National Park Service, Classified Files, 1927-1931, Box 53, National Archives, College Park, Maryland; Charles E. Peterson, "Peterson to Shurcliff," September 22, 1931, Record Group 79 Records of the National Park Service, Classified Files, 1927-1931, Box 53, National Archives, College Park, Maryland; Charles E. Peterson, "Peterson to Smith," September 28, 1931, Record Group 79 Records of the National Park Service, Classified Files, 1927-1931, Box 53, National Archives, College Park, Maryland.

${ }^{78}$ Charles E. Peterson, "Memorandum to Mr. Taylor: Proposed Changes in the Moore House," June 26, 1931, Record Group 79 Records of the National Park Service, Classified Files, 1927-1931, Box 53, National Archives, College Park, Maryland.

${ }^{79}$ Charles E. Peterson, "Memorandum for the Director: Gasoline Stations on the Parkway," June 30, 1931, Record Group 79 Records of the National Park Service, Classified Files, 1927-1931, Box 53, National Archives, College Park, Maryland.
} 
monument, Charles Peterson asserted, "the events at Jamestown succeeding 1607 are interesting but not especially important in American History. To play up any minor stories would be only to endanger the prominence of the really significant fact - the founding of the Virginia Colony in 1607." For Peterson, the goal of the project was to create a "lasting inspiration for American Patriotism." $80 \mathrm{He}$ argued the settlement at Jamestown was historically, not a pleasant place, but a site riddled with disease, Indian attacks, fire, and political discord. ${ }^{81}$ The 1607 date, the initial founding of the Jamestown colony was the best date to memorialize because it eliminated both the "minor" history before the arrival of the English, as well as the distasteful next few years of colonial reality. To recreate Jamestown in 1607, Peterson recommended the extension of the seawall to the Neck of Land area that historically connected Jamestown Island to the mainland and hydraulic backfill within the seawall. ${ }^{82}$ These physical changes to the environment were made to tell the colonial story as preferred and understood at the time.

When the United States plunged into the Great Depression, the face of COLO was changed by CCC labor, which allowed park managers to create their vision of a modern park landscape, and conduct archaeological investigations. CCC labor enabled managers to implement their designs for the creation of an American landscape to

\footnotetext{
${ }^{80}$ Peterson, "Peterson to the Director," December 14, 1931.

${ }^{81}$ Charles E. Peterson, "Memorandum to the Director: Choosing a Date for Jamestown and Other Recommendations," May 29, 1931, Record Group 79 Records of the National Park Service, Classified Files, 1927-1931, Box 53, National Archives, College Park, Maryland.

${ }^{82}$ Ibid.; George C. Gregory, "Gregory to Peterson," May 7, 1931, Record Group 79 Records of the National Park Service, Classified Files, 1927-1931, Box 53, National Archives, College Park, Maryland; H.B. Vaughan, Jr., "Vaughan, Jr. to Taylor," May 2, 1931, Record Group 79 Records of the National Park Service, Classified Files, 1927-1931, Box 53, National Archives, College Park, Maryland. Leading up to his recommendation to return the island to the 1607 shoreline, where a narrow isthmus connected the island with the mainland, Peterson communicated with the Guaranty Trust real estate firm and the Corps of Engineers. George Gregory from the Guaranty Trust Company found a patent map of the Island in 1680 showing an isthmus. Captain Vaughan, Jr. indicated that the earliest American survey was from between 1873 and 1875.
} 
showcase curated shrines to the history of the United States. ${ }^{83}$ As the country

recovered, Congress authorized Colonial National Monument in 1930, just three years

before the formation of the CCC. This New Deal program both provided young,

unemployed men with jobs and allowed the federal government to progress with

public natural resource development projects. ${ }^{84}$ Managers at Colonial National

Monument prepared a work plan for CCC workers and were one of the first national

monuments to receive workers in $1933 .{ }^{85}$ Once a symbol of the area shown on

Jamestown Exposition postcards, CCC workers removed cypress stumps from

Wormley Pond and other waterways and carved mosquito control ditches in the area in

order to create a healthy, modern park and, they believed, slow shoreline erosion. ${ }^{86}$

Although managers were aware of the ongoing erosion of the shoreline, they

did not accept natural change as authentic. While Peterson worked to restore the

shoreline at Jamestown to the 1607 extent, Director Albright simultaneously requested

that any fill at Yorktown maintain the sandy spits that protrude into the river, claiming

these are a key part of the vista. ${ }^{87}$ Hence, the shoreline did not need to be natural, but

\footnotetext{
${ }^{83}$ Bertrand E. Smith, "Smith to the Chief of the Bureau of Biological Survey," April 3, 1935, Record Group 79 Records of the National Park Service, Records of the Washington Office of the Wildlife Division, 1934-1936, Box 2, National Archives, College Park, Maryland; Herbert B. Mette, "Mette to Roosevelt," May 7, 1935, Record Group 79 Records of the National Park Service, Records of the Washington Office of the Wildlife Division, 1934-1936, Box 2, National Archives, College Park, Maryland. At times, the CCC actions did not adhere to the vision of preservation held by federal land managers. President Roosevelt received letters from federal game managers asking for the CCC to stop hunting out of season, without permits, and taking small animals away from their mothers to tame as pets. Sporting clubs wrote asking for CCC to cease burning meadows and leave underbrush in the forests, arguing that these places are key habitat for ducks and other species with recreational importance. However, the sportsmen also ask for soil to be removed and used for construction purposes.

${ }^{84}$ Roderick Nash, ed., The American Environment: Readings in the History of Conservation (Reading, Massachusetts: Addison-Wesley Publishing Company, 1968), 127-30.

85 John C. Paige, "The Civilian Conservation Corps and the National Park Service, 1933-1942"

(Washington, D.C.: National Park Service, 1985), 13, 15.

86 “The Great Dismal Swamp” (Jamestown A\&V Co., 1907), Jamestown Tercentenary Exposition, Hampton Roads, Virginia, Library of Congress, Washington, D.C.

${ }^{87}$ Horace Albright, “Albright to Toms," May 8, 1931, Record Group 79 Records of the National Park Service, Classified Files, 1927-1931, Box 53, National Archives, College Park, Maryland.
} 
needed to appear as if it was. Peterson and Vint rejected the installation of plaques at Jamestown. While they claimed the plaques were "clutter," plaques would have identified the site as a recreated space, rather than the authentic environment they sought. ${ }^{88}$ The CCC graded and prepared the Yorktown waterfront for the installation of a seawall to both limit erosion and prevent the loss of historic sites. Over the next two years, CCC workers prepared portions of Colonial Parkway, reshaped much of the waterfront of Colonial National Monument by grading and sodding coastlines to prevent erosion and performing repairs after hurricanes and storms. ${ }^{89}$ After a hurricane came through the area on September $5^{\text {th }}, 1935$, CCC crews worked to remove felled trees and haul away brush to "remove all signs of the storm." 90

\footnotetext{
${ }^{88}$ Charles E. Peterson, "Peterson to the Director," July 24, 1931, Record Group 79 Records of the National Park Service, Classified Files, 1927-1931, Box 53, National Archives, College Park, Maryland.

${ }^{89}$ E.A. Gissy, "All of the CCC Camp Reports Starting with April 1, 1935-September 30, 1935 and Ending with," varies, Record Group 79 Records of the National Park Service, Narrative Reports Concerning CCC Projects in Nat'l Park Service Areas, 1933-1935, Box 31, National Archives, College Park, Maryland.

${ }^{90}$ B. Floyd Flickinger, "Flickinger to the Director," October 17, 1935, Record Group 79 Records of the National Park Service, Narrative Reports Concerning CCC Projects in Nat'l Park Service Areas, 19331935, Box 31, National Archives, College Park, Maryland; E.A. Gissy, "All of the CCC Camp Reports Starting with April 1, 1935-September 30, 1935 and Ending With," varies, Record Group 79 Records of the National Park Service, Narrative Reports Concerning CCC Projects in Nat'l Park Service Areas, 1933-1935, Box 31, National Archives, College Park, Maryland.
} 


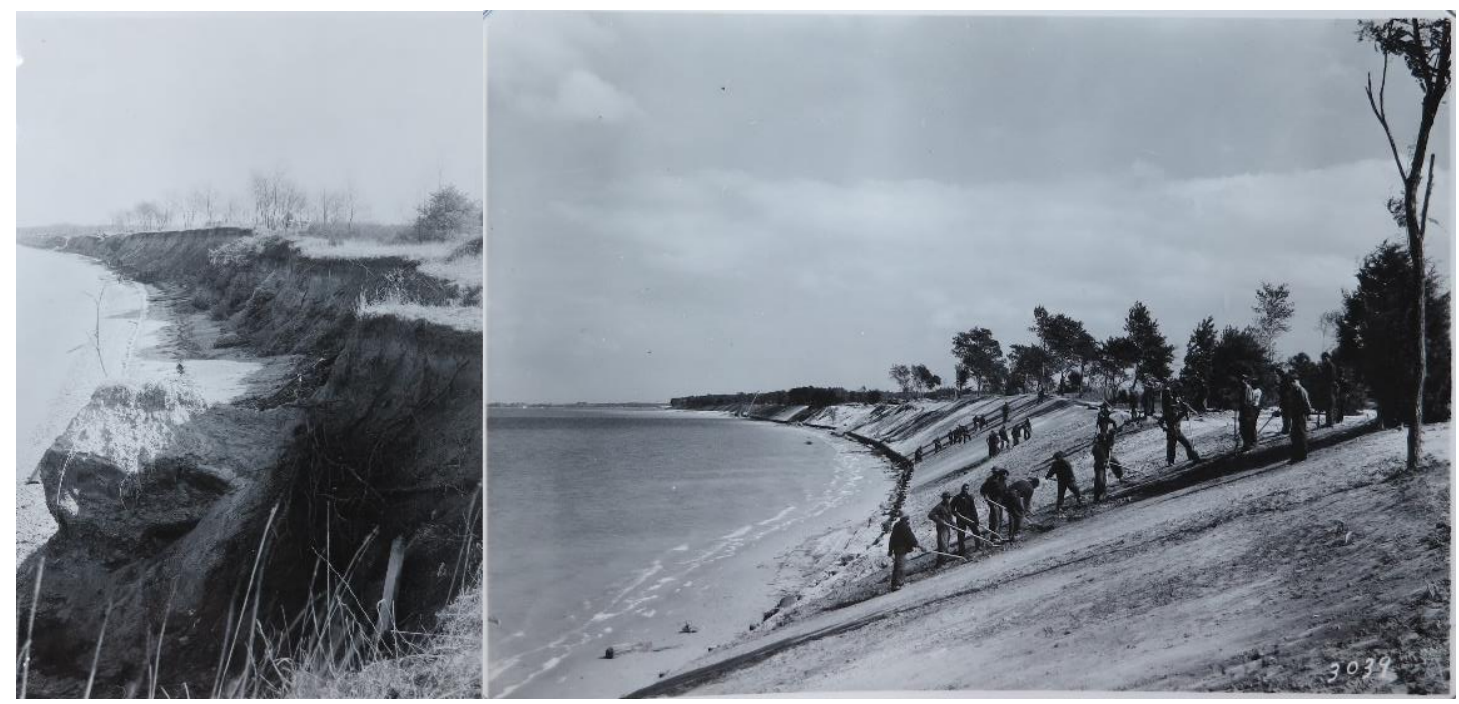

Figure 3. shoreline of Colonial National Monument both before (left) and after (right) CCC crews graded the area. ${ }^{91}$

As NPS managers with the help of CCC laborers created a modern park between the shores of the James and York rivers, the Army Corps became less willing to build structures to protect the island and recreation, with a specific set of environmental requirements, became a bigger priority at COLO. In 1931, the Army Corps decided not to lengthen the seawall, but instead the Civilian Conservation Corps (CCC) installed a 970-meter revetment southeast of the seawall between 1935 and 1936. Through a contractor, the Corps built riprap walls along the James River Portion of the park and backfilled the area. ${ }^{92}$ The Corps did address hurricane damages in the area, replacing a storm-damaged government wharf at Yorktown in 1933 so the park

\footnotetext{
${ }^{91}$ W.H. Underwood, "Photograph No. 1 - March 1, 1935. Before Work Was Started. Station 285 Looking down River," March 1, 1935, Record Group 79 Records of the National Park Service, Narrative Reports Concerning CCC Projects in Nat'l Park Service Areas, 1933-1935, Box 31, National Archives, College Park, Maryland.

${ }^{92}$ Department of the Interior, "Specifications for Constructing Riprap Walls on Section A on the James River, Jamestown Island, Virginia," May 28, 1935, Record Group 79, Central Classified File, 19331949, Box 1976, National Archives, College Park, Maryland.
} 
could continue to rent the structure for concession business. ${ }^{93}$ Similarly, when hurricanes or storms damaged the park, the CCC erased storms from the landscape in the same way that park managers worked to erase shoreline erosion and construction at Yorktown.

In addition to working on the accessibility and appearance of the landscape, CCC workers also conducted archaeological excavations and reconstructed historic features of the park. At Yorktown Battlefield, CCC workers recreated the French Battery and excavated archaeological sites, including one shipwreck site, primarily dating from the Revolutionary War. During the national unrest of the Great Depression, Colonial National Monument would again serve as a site of study and commemoration of a period of romanticized unity in American history. With the "preservation" of historic shorelines well underway due to CCC labor, park attention turned to the archaeological sites that provided some of the rationale for shoreline protection. In 1936, Colonial National Monument became Colonial National Historical Park by an Act of Congress and hired pioneering historical archaeologist J.C. Harrington to study English settlement sites Jamestown Island. ${ }^{94}$ As Harrington worked, he attempted to strike a balance between protecting excavated sites by backfilling them with soil and exposing the brick foundations so visitors could see the authentic colonial materials in the area. ${ }^{95}$ Starting in earnest with the excavations by the CCC, and continuing with Harrington's work, archaeological research at the park

\footnotetext{
93 A.E. Demaray, “The Government Wharf at Yorktown, Virginia,” December 19, 1935, Record Group 79, Central Classified File, 1933-1949, Box 1976, National Archives, College Park, Maryland.

${ }^{94}$ Bruggeman, George Washington Birthplace National Monument: Administrative History 1930-2000, 88.

95 John L. Cotter, "Recommendation for Permanent Preservation of Exposed Masonry Foundations," November 3, 1954, Record Group 79 Records of the National Park Service, Administrative Files, 19491971, Box 1459, National Archives, College Park, Maryland.
} 
increasingly became the priority of federal managers as disciplinary norms and social attitudes began to favor investigation rather than depiction as a mechanism of presenting history.

When the United States entered World War II, COLO adapted to contribute to the country's wartime needs. Park managers transferred sixteen acres of land adjacent to the naval mine depot to military jurisdiction for use as Naval housing. ${ }^{96}$ During the war, and as wounded soldiers returned from Europe, military members and families were offered tours of the park. ${ }^{97}$ During the Cold War, Colonial National Historical Park employees participated in civil defense trainings and Yorktown Battlefield hosting training events. ${ }^{98}$ In the years following World War II, the United States benefitted from a booming economy and even the "shrine" to American beginnings was not immune to Americans increasing interest in leisure space. ${ }^{99}$

\section{Recreational Spaces and the Golden Age of Capitalism}

In 1953, the Superintendent of COLO observed in his annual report that the park was receiving many visitors, but "this visitation is not closely related to the high purposes for which the Park was established but rather to recreational opportunities, particularly at the park beach and the parkway drive." 100 Just a few years earlier, in a

\footnotetext{
${ }^{96}$ Walsh, "Authorizing the Transfer of Jurisdiction of a Portion of the Colonial National Historical Park, Yorktown, VA from the Department of the Interior to the Department of the Navy," § Committee on Public Lands and Surveys (1941).

97 "Preserving the Design for Americans."

98 “Superintendent's Annual Report," May 28, 1951, Record Group 79, Records of the National Park Service, Administrative Files, 1949-1971, Box 108, National Archives, College Park, Maryland.

${ }^{99}$ National Park Service, "Memorandum on the Recreational Resources of Potential Reservoirs of the Upper James River Basin,” April 1945, Record Group 79, Records of the National Park Service, Administrative Files, 1949-1971, Box 638, National Archives, College Park, Maryland.

100 "Superintendent's Annual Report," May 28, 1953, Record Group 79, Records of the National Park Service, Administrative Files, 1949-1971, Box 108, National Archives, College Park, Maryland.
} 
report on recreational opportunities on the James River, the War Department had informed NPS that the requirements for a pleasant recreational environment included a pleasing shore outline, no marshy or swampy conditions, and no mosquitos. ${ }^{101}$ Foreshadowed by the CCC efforts in grading shorelines, sodding riverbanks, and removing cypress stumps, in the years following World War II, park managers improved beach access and constructed visitor use facilities to make the park more modern and comfortable. However, not forgetting these "high purposes," over the next few decades, park managers worked to create or recreate perceived historical environments, with the goal of allowing visitors to learn from a historically authentic setting.

As a part of creating educational or authentic settings, and in preparation for the $350^{\text {th }}$ celebration of the landing of English settlers at Jamestown, event organizers sought NPS permission to reconstruct James Fort on Jamestown Island. ${ }^{102}$ Director of the National Park Service, Conrad Wirth, rejected the reconstruction bid, citing the regional historian by stating "patriotism [is] an emotion...let them view the ruins; let them absorb the atmosphere of the moody swamps, the primitive beauty of the wooded knolls, the lazy ebb and flow of the storied James...let the pilgrims, instead, view the ruins - representing the combined work of Man and Nature - and feel in their hearts: "This is it." ${ }^{" 103}$ However, the debate between park managers about the site as a shrine to be held in place to its date of significance versus a site of learning, to be excavated, studied, and reconstructed to the best academic standards, would continue.

\footnotetext{
101 Ibid., 8-10.

102 Conrad L. Wirth, "Wirth to McMurran," March 2, 1955, Record Group 79 Records of the National Park Service, Administrative Files, 1949-1971, Box 1459, National Archives, College Park, Maryland. ${ }^{103}$ Wirth.
} 
And while Director Wirth considered ruined structures to be the authentic, combined works of man and nature, managers worked to correct the ongoing erosion along the banks of the James and York Rivers.

For the next three decades, managers engineer shorelines that resembled natural processes and continued with the belief that the sense of place contributed to the American identity. At Cape Henry, the first site where English settlers made landfall in 1607, managers worked to stabilize a natural-looking shoreline at Cape Henry. The Chief of Interpretation requested that the shoreline approximate a natural shoreline to emphasize the condition when settlers placed the cross in the area. ${ }^{104}$ The Colonial National Historical Park Master Plan specified "the dune line should be restored and stabilized and the remainder of the area stabilized to create an appearance approaching natural habitat." 105 Cape Henry needed not only to be protected and held in place, but also to appear natural.

As NPS worked to maintain Cape Henry, the Corps continued to place rip rap on the shoreline of Jamestown to protect the English settlement archaeological sites. Despite requests, the Corps rejected proposals for the more costly and time-intensive construction of a seawall at Jamestown, despite coastal erosion threatening important landscape features such as old growth mulberry trees. ${ }^{106}$ Mirroring their decisions in both 1904 and 1931, in 1964, the Army Corps refused to engineer more extensive

\footnotetext{
${ }^{104}$ Ronald F. Lee, "Final Mission 66 Prospectus - Colonial NHP," September 13, 1956, Record Group 79, Records of the National Park Service, Administrative Files, 1949-1971, Box 732, National Archives, College Park, Maryland.

105 Robert L. Steenhagen et al., “A Master Plan for Colonial National Historical Park” (National Park Service, 1971), 90, Record Group 79, Division of Interpretive Planning, Records of Public Input Documenting Interpretive Planning Activities, 1955-1999, Box 59, National Archives, College Park, Maryland.

106 William A.R. Goodwin, “Goodwin to Cramton,” January 13, 1931, Record Group 79, Central Classified File, 1933-1949, Box 1975, National Archives, College Park, Maryland.
} 
shoreline projects to preserve historic sites, aligning their work with commercial navigation. ${ }^{107}$ Despite extensive damage to the middle and lower portions of the Virginia Peninsula from hurricane strikes in 1933 and 1962, the Corps believed there was enough shoreline protection, elevation, and that "there [was] not sufficient development on the Virginia Peninsulas to warrant construction of expensive tidal protective works by the Federal Government." 108 The Corps recommended COLO use coastal spaces for parking lots, golf courses, agricultural fields, or other structures that would survive periodic flooding. ${ }^{109}$

During this period, NPS managers undertook similarly preventative actions. When a series of hurricanes struck the park, demolishing structures, toppling trees, and blocking road access, including the memorable Hurricane Hazel in 1954, Assistant Superintendent Emery wrote to the Regional Director with suggestions for modifications to NPS buildings that would allow hurricane winds to pass through the structures, reduce wind damage to buildings in the event of future storms. ${ }^{110} 111$ Described in monthly narrative reports from the 1950s and 1960s, managers worked to protect the foundations of the historic structures at Jamestown from heavy rains, while leaving repairs to modern structures built for visitor convenience until after storm

\footnotetext{
107 Todd Shallat, "Engineering Policy: The U.S. Army Corps of Engineers and the Historical Foundation of Power," The Public Historian 11, no. 3 (Summer 1989): 21-22, https://doi.org/10.2307/3378610.

108 Secretary of the Army, "Middle and Lower Peninsulas of Virginia," § Committee on Public Works (1964), 20.

109 Ibid., 24.

${ }^{110}$ Emery, "Emery to Regional Director."

${ }^{111}$ Stanley W. Abbott, "Hurricane Damage at Colonial," August 18, 1953, Record Group 79, Records of the National Park Service, Administrative Files, 1949-1971, Box 638, National Archives, College Park, Maryland.
} 
damages occurred. ${ }^{112}$ As federal managers determined where to use their resources, new construction became more responsive to hurricanes and coastal erosion. However, this responsiveness to change did not indicate that managers interpreted hurricane damages, storm surges, or ongoing erosion as authentic or acceptable alterations of the coastline.

Starting in the late 1950s, Mission 66 was an ambitious program of publicity and improvement for the National Park Service leading up to the $50^{\text {th }}$ anniversary of NPS in 1966. Mission 66 material emphasized that during the time of early English settlement, Jamestown was a "semi-island." By the time the COLO was established, Jamestown was an island, separated by erosion at Neck of Land, where the semi-island was once connected to the mainland. ${ }^{113}$ The focus on the creation of the past at the time the colony settled was continued through this island in the 1970s, with managers asking to skip the term island to describe the place, claiming that the term was misleading as the area was a peninsula at the time. ${ }^{114}$ Omitting the term "island" from a site that is today an island may emphasize the change in the landform overtime. The Mission 66 program renewed the program of creating a "proper environment...relatively free from most of the jolting qualities of modern living...a

\footnotetext{
112 John L. Cotter, "Preservation of Excavated Structures," June 6, 1955, Record Group 79 Records of the National Park Service, Administrative Files, 1949-1971, Box 1459, National Archives, College Park, Maryland.

${ }^{113}$ National Park Service, "Mission 66 for Colonial National Historical Park," 1954, Record Group 79, Division of Interpretive Planning, Records of Public Input Documenting Interpretive Planning Activities, 1955-1999, Box 57, National Archives, College Park, Maryland.

114 James W. Corson, "Interpretive Prospectus, Jamestown Island," April 11, 1972, Record Group 79, Division of Interpretive Planning, Records of Public Input Documenting Interpretive Planning Activities, 1955-1999, Box 58, National Archives, College Park, Maryland.
} 
return to the original scene that marked the areas period of maximum greatness." ${ }^{" 15}$ The Mission 66 agenda contributed to environmental changes in COLO at by both altering park spaces for visitor use. In preparation for the celebration, NPS worked overtime to pave the Jamestown Island Loop Tour Road, grade and stabilize waterfront bluffs or sloped areas, and built bridges. ${ }^{116}$

A decade later, NPS prepared the park for the bicentennial celebration of the Battle of Yorktown, this time creating change in the park by removing the historically black Uniontown community from within the park boundaries. ${ }^{117}$ This change created the image of a park consistent with the established importance of the park as a keeper of history from the time of initial English contact and the American colonial period. Originally established during the Civil War for former slaves fleeing the Confederacy, Uniontown or Slabtown was designated by Union troops on Yorktown Battlefield and built by the new community when nearby Fort Monroe was overwhelmed by the number of people seeking freedom. ${ }^{118}$ Originally consisting of 400 cabins, a church, school, and store, some of the descendants of the self-emancipated community remained within park boundaries until the 1970s. Although COLO later highlighted Uniontown's Shiloh Church with wayside markers, the removal of this community asserted that while additions to the visual landscape and park environment such as seawalls that preserved a specific period in history were acceptable, communities within the park that indicated a diverse and complex use and history on the landscape

\footnotetext{
${ }^{115}$ Ronald F. Lee, "Final Mission 66 Prospectus - Colonial NHP," September 13, 1956, 3, Record Group 79, Records of the National Park Service, Administrative Files, 1949-1971, Box 732, National Archives, College Park, Maryland.

116 "Superintendent's Annual Report," June 4, 1959, Record Group 79, Records of the National Park Service, Administrative Files, 1949-1971, Box 75, National Archives, College Park, Maryland.

${ }^{117}$ Lee, "Final Mission 66 Prospectus - Colonial NHP," 66.

118 Goldberger, "Seizing the Past: Revolutionary Memory and the Civil War in Yorktown."
} 
since 1781 were not in line with park interpretive priorities. NPS would interpret Yorktown Battlefield not as a changing landscape, but by presenting a scene more closely depicting the battlefield during the colonial period and made authentic by the archaeological relics on the landscape, such as the subtle remains of trenches, dating from that period.

\section{Ecological Monitoring, Archaeological Site Inventories, and Climate Change}

From the 1960s through the 1980s, shifting national environmental attitudes and priorities became reflected in legislative responsibilities and federal agencies worked to incorporate environmental legislation into site management. As the state of scientific research changed and people became more interested in ecology, the focus of restoring past environments transitioned from one of creating visual similarity, to one of recreating or enabling both an original ecological setting, as well as preserving cultural resources. At COLO, NPS managers began examining and including the natural setting as part of their conservation responsibility and began separating cultural from natural resources in annual reporting. This separation meant that both the natural and cultural setting of the area had standards for preservation. And these standards might conflict with one another. For instance, while agriculture on Jamestown Island was once considered a part of the authentic setting, managers started to examine the impacts of agricultural uses of the area on the local environment.

NPS managers at COLO continued to alter shorelines of the park through "stabilization" processes, which suggests that the original state is both fragile and in need of correction. In 1986, the superintendent determined that the breakwaters along 
the York River were holding drift sand and "no additional soil loss between the breakwaters was seen, indicating this project is a success, at least until now." Not only did the shoreline require stabilization, but the projects to alter this process could be successes or failures based on their ability to retain soil, as opposed to earlier projects which aimed to recreate a historic shoreline. ${ }^{119}$ Previously, agricultural use of the island was a part of the means of establishing an authentic environment as would have existed in the area during the early years of English settlement. Rather than concern with the visual impact, managers preferred to protect Revolutionary War earthworks encouraging grass growth and started focusing on the species of grass to plant on the earthworks, preferring to return to native grass. ${ }^{120}$ This construction protected recreation in the area, the use of the area, and the artifacts in the area rather than the story of the park as laid out in park interpretive documents.

In 1993, COLO Superintendent Alec Gould viewed preventing shoreline erosion at Jamestown and Yorktown as the top priority of the park and included this idea in the new park General Management Plan. The maintenance of museum collections on Jamestown Island also became a priority. While the park had long military connections, the superintendent and others successfully fought the construction of a large industrial Navy pier at Yorktown. Despite the historic military use of the area, modern military construction was no longer consistent with the historic and commemorative landscape. Park managers believed the modern

\footnotetext{
${ }^{119}$ Richard H. Maeder, “Superintendent's Annual Report, Calendar Year 1980: Colonial National Historical Park, Yorktown, Virginia," March 5, 1987, Record Group 79, Superintendents Annual Narrative Reports, 1980-2001, Box 14, National Archives, College Park, Maryland.

${ }^{120}$ Wallace N. Neprash, "Superintendent's Annual Report, Calendar Year 1980: Colonial National Historical Park, Yorktown, Virginia," March 8, 1989, Record Group 79, Superintendents Annual Narrative Reports, 1980-2001, Box 14, National Archives, College Park, Maryland.
} 
construction would distract from the historic environment the park presented; thus dredging and creating change was fine, but the appearance of modern equipment and alteration was not. ${ }^{121}$ Even the stated purpose of the Green Spring Plantation unit of the park changed from "leasing and recreation," to "resources protection and research," representing a broader trend in park management. ${ }^{122}$ Previous programs of restoring the environment to visual similarity with a 1607 or 1781 environment were no longer enough. Park management priorities have diversified to include goals for the maintenance of ecological systems, in addition to the preservation of Jamestown Island and Yorktown Battlefield.

Emblematic of this shift, the cypress tree that stood in the James River that was believed to mark the site of James Fort was felled during a storm in $1993 .{ }^{123}$ Over the next three years, APVA archaeological investigations on Jamestown Island began and the fort was rediscovered to be only partially submerged, with the majority of the structure remaining on land. Researchers and park managers long operated under the assumption that James Fort eroded into the James River. ${ }^{124}$ The discovery of this fort on land presented an opportunity for archaeological research into the habits and conditions of this early English settlement and contributed to park goals of a more “accurate" interpretation of these places. From 1992 until 1997, managers worked with the Colonial Williamsburg Federation and the College of William and Mary to conduct an archaeological survey of Jamestown Island. This survey identified

\footnotetext{
${ }^{121}$ Alec Gould, "Superintendent's Annual Report 1993," March 20, 1994, Record Group 79, Division of Land Acquisition, Land Acquisition Files, 1933-1970, Box 15, National Archives, College Park, Maryland.

122 Alec Gould, “Superintendent's Annual Report 1992," March 30, 1994, Record Group 79, Division of Land Acquisition, Land Acquisition Files, 1933-1970, Box 15, National Archives, College Park, Maryland.

123 Gould, "Superintendent's Annual Report 1993."

${ }^{124}$ Steenhagen et al., "A Master Plan for Colonial National Historical Park," 29.
} 
archaeological resources from the duration of human history on the island, starting 12000 years before present. Alongside technological advances and the development of the discipline of archaeology, the expansion of the scope of study on the island suggests that management priorities in the area are shifting to include sites outside of the period defined by park management literature. Today, prehistoric sites, as well as other sites that have been excluded from the history of COLO in the past such as Civil War sites are preserved and managed. The "American" identity the site represents has expanded to discuss, if not include the centuries of Native American history at the site, as evidenced by the scope of the archaeological investigation.

On the national stage, NPS managers and various other governments, agencies, organizations and individuals have become concerned with the impact of climate change on natural and cultural resources, as well as cities, communities, and individuals. Scientists characterize climate change threats as alterations in local climate patterns that may cause a change in the physical condition, material preservation, species characteristics, relative sea level, storm surge or flood risk, or a number of other conditions. ${ }^{125}$ NPS landscapes have always been threatened by many of these climate factors and NPS documents specify that climate change represents an increased threat or new combination of existing threats that may cause a novel environmental situation. ${ }^{126}$ Assigning threats of change as risk factors suggests that the risk from climate change comes from an alteration of the previous state. At COLO, coastal erosion is a dominant feature of the system and is projected to increase with

\footnotetext{
${ }^{125}$ Maria A. Caffrey and Rebecca L. Beavers, "Planning for the Impact of Sea-Level Rise on U.S. National Parks," Park Science 30, no. 1 (Summer 2013): 6-13.

${ }^{126}$ Marcy Rockman et al., "Cultural Resources Climate Change Strategy" (Washington, D.C.: Cultural Resources, Partnerships, and Science and Climate Change Response Program, National Park Service, 2016).
} 
climate change. Climate change processes may increase coastal erosion and contribute to the complete or partial erosion of coastal archaeological sites, the disappearance or decline of species, the loss of memory or traditional knowledge associated with landscape, or loss or damage to coastal historic structures. ${ }^{127}$ In a reconnaissance survey of archaeological sites on Jamestown Island, researchers found that two known archaeological sites have already been lost to coastal erosion, twenty-four are in the process of being eroded or submerged, and they anticipate that by 2065 , only two NPS archaeological sites on Jamestown Island will remain entirely above water. ${ }^{128}$ A 2016 report published by NPS recommends the removal of certain coastal protection structures along Jamestown Island to allow for the continuation of coastal erosion and accretion processes in sites where cultural resources are not likely to be impacted. ${ }^{129}$ In addition to their value as a part of the landscape, current archaeological research methods and current park service priorities emphasize the in-context preservation of these sites, their irreplaceable nature, and research value.

While earlier management procedures identified the maintenance of shorelines as an authentic presentation of space, current managers identify archaeological sites as key park features for preservation. Climate change and erosion are now a risk to the generation of knowledge and scientific discovery, as well as the ability of managers to maintain and present park resources in their preferred way. Climate change and erosion in the area may impact archaeological sites that have become more important

\footnotetext{
${ }^{127}$ Marissa Morgan et al., "Climate Change Impacts on Cultural Resources" (Washington, D.C.: National Park Service Cultural Resources Partnerships and Science, 2016), 6.

${ }^{128}$ Hayden F. Bassett, "The Effects of Sea Level Rise on the Archaeological Resources of Jamestown Island (2016), 11.

${ }^{129}$ Karl F. Nordstrom and Nancy L. Jackson, "Facilitating Migration of Coastal Landforms and Habitats by Removing Shore Protection Structures: An Adaptation Strategy for Northeast Region Units of the National Park Service," Natural Resource Report (Fort Collins, Colorado: National Park Service, June 2016).
} 
as archaeologists have altered their research interests to include more sites. This expanding claim of American identity beyond the location of the 1607 shoreline has contributed to some of the perceived climate change risks at COLO today. In addition to the archaeological remains of early English settlement, managers at COLO today are investigating archaeological sites associated with slave history, early Native American sites, Civil War sites, and self-emancipated community locations. Thus, the perceptions of climate change risk at the site are associated with the erosion and degradation of many additional sites that earlier managers may have been less concerned with.

COLO managers recently conducted and participated in a climate change vulnerability assessment process to gather information required to begin planning adaptation strategies to address climate change impacts. As a part of this process, managers considered the natural, built, and recreational components of the landscape and assessed the exposure of these resources to climate change based on climate change modelling, the sensitivity the materials which compose these sites have to various climate factors such as salt-water intrusion at an archaeological site, and the ability of the site to change, or be changed by managers while retaining the characteristics that represent current NPS priorities. ${ }^{130}$ Early managers of the Jamestown-Yorktown area conducted archaeological research, but much of the educational value of the landscape came from the retention of shorelines, landscapes, and the original setting of commemorated events that took place at the site. NPS values, in the context of changing disciplinary methods, technologies, and national

\footnotetext{
${ }^{130}$ Ricci et al., "Colonial National Historical Park Integrated Coastal Climate Change Vulnerability
} Assessment: A Pilot Method." 
priorities, place a greater value on the educational possibilities from scientific investigation of the historic artifacts on the landscape. This shift in priorities is reflected in current climate change management decisions, as COLO staff work to prioritize which archaeological sites to save, within the bounds of both national priorities and budget constraints.

With climate change, the symbolic nature of Jamestown Island as the birthplace of the nation has reemerged, with activists promoting climate change response using the image of the erosion and inundation of the "birthplace of America" to antagonize an American response. As climate change activists try to generate public action in response to climate change, numerous reports harness the symbolic power and meaning with titles such as, "With Rising Seas, America's Birthplace Could Disappear." ${ }^{\prime 131}$ Today, as organizations including the Union of Concerned Scientists, National Park Service, National Trust for Historic Preservation, as well as other community, local, state, and private partners are using the image of Jamestown as the "birthplace of America" to emphasize the scale and scope of climate change and generate attention and support for the preservation of historic structures,

\footnotetext{
${ }^{131}$ Charles Q. Choi, "Rising Seas Could Submerge the Oldest English Settlement in the Americas," Live Science, November 30, 2017, https://www.livescience.com/61063-rising-seas-may-destroyarcheological-sites.html; Cassandra Khaw, "Historic Jamestown Will Likely Be Underwater by the End of the Century," The Verge, June 6, 2014, https://www.theverge.com/2014/6/6/5785270/jamestown-atrisk-from-rising-sea-level; "Climate Change Threatens to Sweep Away Historic Jamestown Settlement," The Guardian, June 5, 2014, https://www.theguardian.com/world/2014/jun/05/jamestownsettlement-rising-sea-level-threat; Christopher Joyce, "With Rising Seas, America's Birthplace Could Disappear," National Public Radio, May 14, 2013, http://www.npr.org/2013/05/14/178809495/withrising-seas-americas-birthplace-could-disappear; Rex Springston, "Jamestown Faces a Future of Rising Tides: As Sea Levels Rise Across the Globe, Virginia's Most Historic Island Could Be Flooded by 2100," Richmond Times-Dispatch, March 10, 2013, http://www.richmond.com/news/virginia/jamestown-faces-a-future-of-rising-tides/article_7c6e60c711fc-5bba-82a2-530f7c7b0385.html.
} 
archaeological sites, and other heritage locations. ${ }^{132}$ However, much like the priorities of managers at COLO have shifted, from early commemorative uses of the space to early research and preservation work of APVA, to creating an American shrine, to research into the prehistoric American past, preservation decisions that managers make today evidence current management priorities.

\section{Representing the 'Birthplace' of America on a Climate Change Landscape}

The ongoing erosion of the banks of the York and James Rivers has flavored the relationship between people and their environment in this area throughout American history. Early English settlers saw a "wholesome" climate and a defensible military position, relocating forts as they were affected by coastal erosion. ${ }^{133}$ As the use of the landscape changed, the ongoing coastal erosion was seen as a threat to the preservation of a historic shoreline and setting. The "hand of time," was listed amongst the threats from which the Association for the Preservation of Virginia Antiquities would protect the cultural resources. However, starting in the late $19^{\text {th }}$ century, as the Corps and NPS started preserving archaeological sites and land in the area, the ongoing shoreline erosion became a threat to the intended use of the space and this threat affected the local relationship between managers and environment in a way that still flavors interactions today. From 1930 onwards, the environment of the park has been altered by ongoing coastal erosion, invasive species, and human design

\footnotetext{
132 Debra Holtz et al., "National Landmarks at Risk: How Rising Seas, Floods, and Wildfires Are Threatening the United States' Most Cherished Historical Sites” (Union of Concerned Scientists, 2014), 17, http://www.ucsusa.org/sites/default/files/legacy/assets/documents/global_warming/NationalLandmarks-at-Risk-Full-Report.pdf.

133 Hale, "Ralph Lane to Sir Francis Walsingham, 12th August 1585"; Adams, The Best and Worst Country in the World: Perspectives on the Early Virginia Landscape, 111; Deans, The River Where America Began: A Journey Along the James, 58. Ralph Lane wrote to Sir Francis Walsingham in 1585 that the Virginia "Clymate ys soo whoollesom, yeate somwha tendying to heate..."
} 
to meet recreational needs and expectations for the space. While managers have consistently known and understood change, especially shoreline erosion, to be a part of the system at COLO, management responses to changing conditions have been based on current management goals and priorities for the site. And these goals and priorities have often required a more static shoreline.

Overtime the preservation of archaeological sites and artifacts rather than restoration of historic coastlines, towns, and structures has become the dominant motivation behind federal managers' perceptions of and responses to environmental change. However, as the preservation priorities on the landscape change due to better technologies for archaeological investigation and interests in the archaeological evidence of Native American societies, non-white American histories, and previously underrepresented time periods, managers may be confined by park management documents and the findings of earlier archaeological surveys and inventories. As federal managers work to address the impacts of climate change on cultural resources at COLO, existing management plans and documentation may enable the preservation of sites that no longer represent modern American priorities and in addition to addressing climate change, managers may need to address these path-dependencies in site prioritization and decision-making.

More than just the preservation of tangible cultural resources, as federal managers have worked to maintain the shoreline and archaeological sites of Jamestown Island and the Yorktown waterfront, they have worked to protect an American identity. Climate change, sea level rise, increasing coastal erosion, storm surge, and flooding threaten the cultural resources, as well as the choices managers 
can make in protecting them. While in the past, the Corps and NPS have been able to construct seawalls and lay rip rap to protect coastlines, climate change may impact the control over the location to the shoreline and the number of reasonable responses to the shoreline change given existing political resources and priorities. Though managers in the area have consistently recognized ongoing erosion and environmental change in the system, the ability to maintain the commemorative landscape given modern priorities represents a new situation for Americans to contend with in the "birthplace" of the country. 


\section{CHAPTER 4: FROM MILITARY FORTRESS TO RECREATIONAL HAVEN:}

\section{FEDERAL MANAGERS' EXPECTATIONS OF PERMANENCE ON SHIFTING}

\section{SANDS IN PENSACOLA AND THE MISSISSIPPI BARRIER ISLANDS}

When Spanish explorers under the command of Tristan de Luna arrived in Pensacola Bay in 1559, they observed a deep, spacious port with a 5-meter bar at its entrance, good soil, fruit-bearing trees, and Native American fishing huts along the shore. ${ }^{134}$ The Luna Expedition intended to settle in Pensacola in order to bolster Spanish presence in the Gulf of Mexico as French interest in the region was increasing. ${ }^{135}$ Five weeks after their arrival, a hurricane struck Luna's fleet anchored in Pensacola Bay, destroying many of the supplies required to start the colony. ${ }^{136}$ During the late $16^{\text {th }}$ century, the southeastern portion of North America was in the middle of a period of unpredictable weather due to the global consequences of volcanic activity in the eastern Pacific. ${ }^{137}$ Spanish settlers looked for sustenance in Native American villages $;{ }^{138}$ however, abnormal drought conditions and storminess during this period likely affected the food supplies of tribes and restricted excess stores. ${ }^{139}$ Within two years of arrival, the Luna Expedition abandoned Pensacola to focus on the Atlantic coast of Florida.

\footnotetext{
${ }^{134}$ Leonard, Spanish Approach to Pensacola, 1689-1693, 4.

${ }^{135}$ Hoffman, Florida's Frontiers, 38.

${ }^{136}$ William S. Coker, "Pensacola, 1686-1821," in Archaeology of Colonial Pensacola, ed. Judith A. Bense (Gainesville, Florida: University Press of Florida, 1999), 6.

${ }^{137}$ Dennis B. Blanton, "The Factors of Climate and Weather in Sixteenth-Century La Florida," in Native and Spanish New Worlds: Sixteenth-Century Entradas in the American Southwest and Southeast, ed. Clay Mathers, Jeffrey M. Mitchem, and Charles M. Haecker (Tucson, Arizona: University of Arizona Press, 2013), 99-120.

${ }^{138}$ Robert S. Weddle, Spanish Sea: The Gulf of Mexico in North American Discovery, 1500-1685 (College Station, Texas: Texas A\&M University Press, 1985), 268.

${ }^{139}$ Blanton, "The Factors of Climate and Weather in Sixteenth-Century La Florida."
} 
The Luna Expedition retreated from Western Florida in 1561 due to storm damages. Storms in the Northern Gulf cause sand along the barrier islands and beaches to erode and accrete, changing the shape, elevation, and topography of the barrier islands and beaches in the area. ${ }^{140}$ From the time of early European settlement in the area, through the present, the motion of sand on the Florida and Mississippi barrier islands has been a defining feature of the landscape. And throughout this same period, various federal managers of this coastal area including Spanish, British, and French military officers, U.S. Army Corps of Engineers and most recently the National Park Service have constructed and modified this coastal landscape to adhere to military and recreational uses and priorities. Since the early American period, federal managers have engineered larger environmental changes in the system, such as dredging, sand deposition, and to accommodate changing military technologies and recreational needs. Despite a long-standing understanding of environmental change and barrier island turnover from evidence of ruins, contemporary storm events, and scientific findings, federal managers have consistently approached the landscape with an expectation that structures on the coastline or the coastline itself is or can be engineered to be permanent.

As anthropogenic climate change enhances the speed of sea level rise, the severity of storm surge, erosion, and flooding, and creates new risks through a combination of these factors, federal managers in the area now defined as Gulf Islands National Seashore (GUIS) are likely to face additional challenges in managing the recreational, historic, and natural landscape in this area. Existing management

\footnotetext{
${ }^{140}$ Florida Department of Environmental Protection, Division of Water Resources Management, Bureau of Beaches and Coastal Systems, "Hurricane Dennis and Hurricane Katrina: Final Report on 2005 Hurricane Season Impacts to Northwest Florida" (Tallahassee, Florida, April 2006).
} 
structures and environmental perceptions will inform ongoing federal management efforts in the face of climate change. ${ }^{141}$ As federal managers have addressed shifting sands in Pensacola and the Mississippi Barrier Islands, and as the landscape has transitioned from a military to a recreational space, management priorities, rather than the mechanisms of preserving and protecting coastlines and the coastal built environment, have changed. While federal managers' visions of how to engineer permanence in this landscape have changed overtime, the expectation that a barrier island system can be controlled to establish a stable site or use has remained constant. Early American military managers engineered "permanent" structures on the coastline. As these structures began to decay and coastal fortifications became obsolete, managers began to manipulate the environment to make the coastline, as well as the commercial uses in the area permanent. Engineered attempts at permanence continued as the National Park Service established GUIS and worked to maintain historic structures and recreational spaces in place. In the current set of negotiations between uses of the space and the local environmental features, manager's expectations of permanence of both the natural coastline and built coastal structures, on a shifting landscape, are informing the climate change adaptations options and choices for the natural and built landscape of GUIS.

\section{Landscapes of Early Spanish, English, and French Pensacola and Gulf Islands}

The Gulf of Mexico formed approximately 300 million years ago, with five subsequent, major periods of sediment deposition and movement forming the structure

${ }^{141}$ William H. Sewell, Jr., “A Theory of Structure: Duality, Agency, and Transformation,” American Journal of Sociology 98, no. 1 (July 1992): 1-29. 
of the Gulf as seen today. ${ }^{142}$ The oldest amongst the chain of barrier islands that stretch from Louisiana to Florida formed approximately 5000 years ago. ${ }^{143}$ The northeastern Gulf Coast has numerous estuaries, protected by these barrier islands, or salt marsh and mangrove systems located where freshwater rivers meet the saline Gulf. ${ }^{144}$ Overtime, the series of barrier islands stretching along the northern Gulf Coast, along the land area that is currently the United States' Louisiana, Mississippi, Alabama, and Florida have moved in the 5000 years since their formation, with hurricanes, storms, and most recently dredging of ship channels enabling these islands to change shape and move in a southwestern direction. Early inhabitants of the northeastern Gulf Coast included the Mobile and Pensacola people. ${ }^{145}$ Spanish sailors may have reached the Pensacola area as early as 1502 , with the first permanent settlement attempted in 1559. ${ }^{146}$

${ }^{142}$ D.M. Worrall and S. Snelson, "Evolution of the Northern Gulf of Mexico, with Emphasis on Cenozoic Growth Faulting and the Role of Salt," in Geology of North America: An Overview, vol. A, The Decade of North American Geology Project Series (Boulder, Colorado: The Geological Society of America, 1989), 97-98; James L. Pindell, "Alleghenian Reconstruction and Subsequent Evolution of the Gulf of Mexico, Bahamas, and Proto-Caribbean," Tectonics 4, no. 1 (January 1985): 1-39. ${ }^{143}$ Ervin G. Otvos, "Coastal Barriers, Gulf of Mexico: Holocene Evolution and Chronology," Journal of Coastal Research 42, no. Special Issue (Spring 2005): 141-63; Ervin G. Otvos and Marco J. Giardino, "Interlinked Barrier Chain and Delta Lobe Development, Northern Gulf of Mexico," Sedimentary Geology 169, no. 1-2 (July 2004): 47-73.

${ }^{144}$ Florida Department of Environmental Protection, "Florida's Coast: A National Treasure," in Development and Evaluation of Sediment Quality Assessment Guidelines, vol. 1, 1994 Florida Sediment Quality Assessment Guidelines (SQAGs) (Tallahassee, Florida: Florida Department of Environmental Protection, 1994), 6-11.

${ }^{145}$ Irving A. Leonard, Spanish Approach to Pensacola, 1689-1693 (Albuquerque, New Mexico: The Quivira Society, 1939).

${ }^{146}$ Paul E. Hoffman, Florida's Frontiers, A History of the Trans-Appalachian Frontier (Bloomington, Indiana: Indiana University Press, 2002); Verne E. Chatelain, The Defenses of Spanish Florida, 15651763 (Washington, D.C.: Carnegie Institute of Washington, 1941); Leonard, Spanish Approach to Pensacola, 1689-1693. 


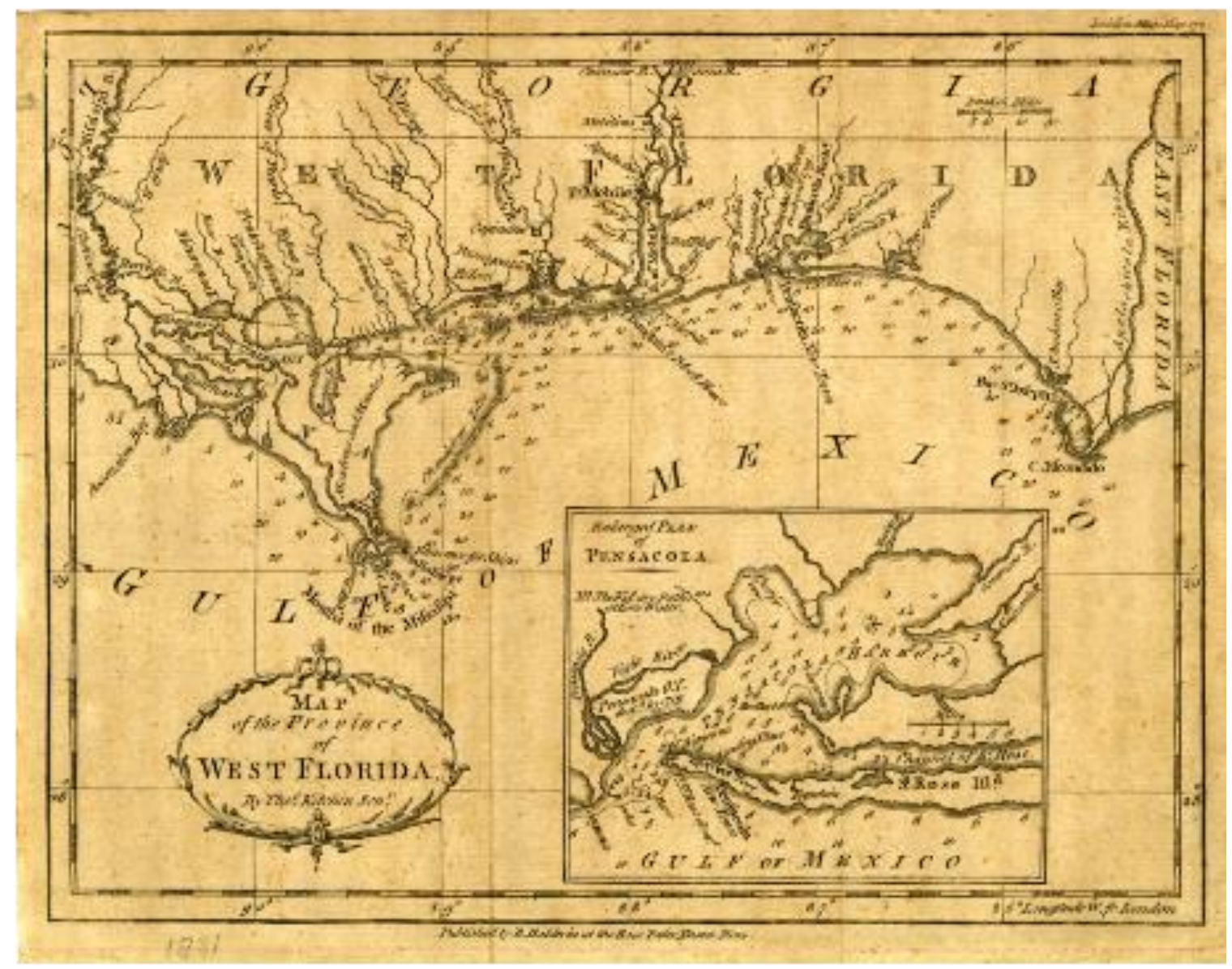

Figure 4. Map of West Florida, $1784 .{ }^{147}$

A century later, Spanish monarchs, upon hearing of French expeditions in the Gulf of Mexico, turned their attention once more to settling the Northern Gulf to retain Spanish claims in the area. In 1693, a Spanish party under the leadership of Pez and Siguenza entered Pensacola Bay and two years later, Arriola settled in Pensacola, founding the Presidio on land facing the entrance to the bay, near the current location of Fort Barrancas. ${ }^{148}$ Despite plans for a battery on the western end of Santa Rosa Island, Spaniards did not build in this location because they found it to be "a waterlevel islands of shifting sand, all of it so marshy and low that it cannot make any kind

\footnotetext{
147 Thomas Kitchin, Map of the Province of West Florida (London: R. Baldwin, 1781), Florida Map Collection, State Library of Florida, https://www.floridamemory.com/items/show/323242.

${ }^{148}$ Robert L. Gold, Borderland Empires in Transition: The Triple-Nation Transfer of Florida (Carbondale, Illinois: Southern Illinois University Press, 1969).
} 
of fortification." ${ }^{149}$ By 1713, Father le Maire wrote to the Governor of West Florida, requesting permission to move the Presidio to this area of shifting sands on the western end of Santa Rosa Island due to wind and seas at the coastal location on the mainland. ${ }^{150}$ Ten years later, the Spanish military presence in the area moved the presidio to Santa Rosa Island; however, they built approximately three-quarters of a mile to the east on the north side of the island on slightly higher ground. ${ }^{151}$ Frenchman Dominic Serrest observed that piles for the foundation were "driven so far into the sand that wind and water could not too greatly weaken them." ${ }^{152}$ Despite this attempt to construct a more permanent structure in this location, Field Marshall Pedro de Rivery wrote to the viceroy of New Spain and again requested to move the presidio back to the mainland, leaving a small guard on Santa Rosa Island to protect it from foreign invasion.

During the same period, the Mississippi Barrier Islands were part of the French empire. French traveler Jean-Bernard Bossu described French storehouses, fort, and barracks on Dauphine Island, South of Mobile, Alabama. In 1717, a hurricane hit the island, and the French governor responded by moving to the mainland and encouraging the port to move to Surgere Island, now Ship Island, south of Biloxi, Mississippi. ${ }^{153}$ In 1719, after a series of attacks, the French took Pensacola for four years until the Spanish regained the area in 1723 as part of an ongoing battle for

\footnotetext{
${ }^{149}$ Albert Manucy, “The Founding of Pensacola-Reasons and Reality," Florida Historical Quarterly 37, no. 3 and 4 (1959): 235.

${ }^{150}$ Coker, "Pensacola, 1686-1821," 12.

${ }^{151}$ William S. Coker, "Pensacola, 1686-1821," in Archaeology of Colonial Pensacola, ed. Judith A. Bense (Gainsville, Florida: University Press of Florida, 1999), 12, 15.

${ }^{152}$ Ibid., 16.

${ }^{153}$ Seymour Feiler, trans., Jean-Bernard Bossu's Travels in the Interior of North America, 1751-1762 (Norman, Oklahoma: University of Oklahoma Press, 1962).
} 
imperial possession in the Gulf of Mexico. ${ }^{154}$ After the Spanish regained the area, the new Spanish governor Lt. Col. Alejandro Wauchope received orders from The Viceroy to construct a canal across Santa Rosa Island to lower the water level in Pensacola Bay and make the area less accessible to enemy vessels. However, this early environmental modification did not prove effective and the King of Spain instead suggested a blockade of store ships across the entrance to the Bay to repel enemy forces. ${ }^{155}$

Back in Spanish hands, a hurricane in 1752 damaged most of the structures on Santa Rosa Island except the storehouse and hospital, the new viceroy, in 1756, accepted the request to move to the mainland. ${ }^{156}$ Although Spanish colonial managers of this space did not abandon the storm-prone area entirely, the retreat to the mainland shows that Spanish managers of this coastal space saw relocation rather than environmental modification as the way to address environmental volatility. Early managers abandoned the idea of creating permanent structures in the area and retreated to seek more stable environmental conditions on the mainland of Florida. The Treaty of Paris, ending the Seven Years War, gave the expensive and unprofitable Spanish Pensacola to the British in $1763 .{ }^{157}$ In 1766, 1772, and 1778 hurricanes struck the Pensacola area. In his natural history of the Floridas, Romans describes treefalls extending 30 miles inland from the 1772 hurricane. ${ }^{158}$ In 1783, Spain retook West Florida while Britain focused on the American Revolution. Throughout the early

${ }^{154}$ Gold, Borderland Empires in Transition: The Triple-Nation Transfer of Florida, 10.

${ }^{155}$ Coker, "Pensacola, 1686-1821," 16.

${ }^{156}$ Ibid., 18.

${ }^{157}$ Stanley Faye, "Spanish Fortifications of Pensacola, 1698-1763," The Florida Historical Quarterly 20, no. 2 (October 1941): 168.

${ }^{158}$ Bernard Romans, A Concise Natural History of East and West Florida; A Facsimile Reproduction of the 1775 Edition with Introduction by Rembert W. Patrick, Floridiana Facsimilie \& Reprint Series (Gainsville, Florida: University Press of Florida, 1962). 
European history, hurricanes and the accompanying storm surge and erosion in Pensacola and the Mississippi Barrier Islands shaped the human history of these areas. As hurricanes struck, Spanish forces moved forts between the islands and the mainland. Soon after particularly destructive hurricanes in 1722 and 1772, French and British presence in the area, respectively, turned the area over to Spanish forces with little resistance.

Despite the strategic importance of the Mississippi Barrier Islands for their proximity to New Orleans and their access to other colonial possessions in the Gulf of Mexico, hurricanes and resulting damages disrupted the national priorities of Spanish, French, and British forces in these locations. Managers perceived hurricanes as cause to relocate, although often not until after the storm had caused damages and the viceroy or a political authority, who may not have been present in the geographic area, granted permission. ${ }^{159}$ The volatility of the climate altered the patterns of use in these places by altering who controlled the area, where they built, and how they tailored construction efforts to the local environmental conditions. Pensacola and Mississippi Barrier Islands changed due to hurricanes, storms, and the accompanying erosion and movement of sand. However, European military outposts' relocation and reconstruction in response to these impacts affected the patterns of travel and use in these places.

\section{Fortifying and Establishing an American Nation on the Gulf Coast}

The wide, protected expanse of Pensacola Bay and the deep harbors of Ship Island served as important strategic military locations, initially for the Spanish,

${ }^{159}$ Faye, “Spanish Fortifications of Pensacola, 1698-1763,” 163-64. 
French, English, and Spanish empire (again), before becoming a key military point for the United States when President Monroe purchased the area from Spain in 1819 for $\$ 5,000,000$. The United States had previously acquired the Mississippi-Alabama barrier islands from France as part of the Louisiana Purchase in 1803 and took possession of East and West Florida, including the Mobila district extending through modern day Mobile, Alabama in 1821. When the United States acquired West Florida in 1821, President Monroe, harnessed the residual fear of Naval threat following the War of 1812 to ask Congress to build up coastal defenses around the United States. This construction program of coastal fortifications, known as "third system" forts, stretched from New England to San Francisco and featured masonry construction and heavy gun mountings. ${ }^{160}$ Along the Gulf Coast, President Monroe specifically called for additional coastal defenses and infrastructure to protect the approach to New Orleans, mentioning anchorages at Horn, Ship, and Cat Islands. ${ }^{161}$ His eagerness to build military fortifications at Pensacola and on the Mississippi Barrier Islands represented a change in the perception of the space during the early American period. The American military would go on to construct large, masonry forts and accompanying structures on the end of Santa Rosa Island, mainland Pensacola, Perdido Key, and Ship Island. Rather than retreat or rearrange patterns of use in the area, the U.S. military would engineer the shorelines of these spaces around fixed fortifications. These large masonry forts and other military installations established

\footnotetext{
160 John R. Weaver II, A Legacy in Brick and Stone: Coastal Defense Forts of the Third System, 18161867 (Missoula, Montana: Pictorial Histories Publishing Company, 2001).

${ }^{161}$ James Monroe, "Message from the President of the United States, upon the Subject of Fortifications on Dauphine Island and Mobile Point" (Gales and Seaton, March 26, 1822), U.S. President (Monroe), Folder "Message...upon the subject of fortifications on Dauphine Island," University of West Florida Archive and West Florida History Center.
} 
expectations of permanence in a natural setting of change and motion that would continue as the landscape transitioned from a military to a recreational space.

Immediately after President Monroe called for construction of defensive works along the Gulf of Mexico, the U.S. military began scouting and planning efforts in the area. For the Chief Engineer on the project, hurricanes were a consideration. However, environmental change along the Gulf Coast due to hurricanes justified, rather than presented a risk to, the construction of coastal defenses in the area. The Chief Engineer found that "tempests, hurricanes, fireships, can in a few hours destroy or disperse all [floating] means of defense; and in the Gulf of Mexico, where hurricanes are so frequent, this objection may be considered as conclusive." 162 In times of war, he reasoned, the U.S. Navy would not be able to rebuild floating defenses rapidly enough to wage war without the support of a land-based operation. While at the mercy of the weather at sea, on land, the Chief of Engineers believed his bureau could engineer stable fortifications that would withstand storms. The Chief of Engineers confidence in coastal construction in the area was echoed by General Edmund Gaines.

A distinguished officer of the War of 1812, General Gaines acquired local knowledge of the Pensacola area during the Seminole Wars. In 1826, the Secretary of War sent General Gaines to report on the defensibility of Pensacola Bay by land and sea. He found Pensacola to be an advantageous site for coastal fortifications, recommending the Army build forts at the eastern and western approaches to Pensacola Pass. General Gaines observed the semi-ruined state of Fort St. Rose and

\footnotetext{
${ }^{162}$ Monroe, "Message from the President of the United States, upon the Subject of Fortifications on Dauphine Island and Mobile Point."
} 
attributed this to wind and sand drift. ${ }^{163}$ Despite observing damages to previous

fortifications but wind and sand drift, General Gaines recommended construction of forts on either side of Pensacola pass to protect the area from attack by a foreign navy. Two years later, in 1829, the Secretary of the Navy sent Commodore John Rodgers, a distinguished Naval veteran of the Quasi-War and War of 1812, to visit Pensacola and estimate the "value and aptitude" of the site for naval use. Commodore Rodgers did not favor the site, citing both the expense of removing the sand to lower the bar into Pensacola and ongoing need to dredge and prevent shoaling in the area due to the "fine, moveable sand." ${ }^{164}$ While General Gaines was familiar with the land area of Pensacola, from a naval perspective, Commodore Rodgers expressed concern with ongoing coastal erosion and accretion, the ongoing maintenance these conditions would require, and the role this maintenance would play harbor access and construction.

Despite Commodore Rodgers concerns, the Army started construction on Fort Pickens, on the western tip of Santa Rosa Island, in 1829. On the national stage, the Rivers and Harbors Act passed in 1824, and aligned the work of the Army Corps of Engineers with commercial navigation in U.S. waterways. In a speech to Congress in 1836, Mr. White, a delegate to the U.S. House of Representatives for the Florida Territory, lobbied for more Naval appropriations for the defenses of Pensacola. Motivated by the desire to bring a military presence, jobs, and harbor improvements to

163 "Message from the President of the United States, with a Report from the Secretary of War, Transmitting the Inspection Returns of Brevet Major General Gains, for 1826 and 1827, Relating to the Organization of the Army and Militia," 11.

${ }^{164}$ U.S. Secretary of the Navy, "Annual Report Showing the Condition of the Navy in the Year 1829," December 8, 1829, 358, U.S. Secretary of the Navy, University of West Florida Archive and West Florida History Center. 
the territory, he argued that the live oak and other supplies in the area, the potential for year round construction given the lack of winters, and the potential improvements including inland canals and railroads to support Southern industry made Pensacola a good investment. ${ }^{165} \mathrm{Mr}$. White's interest in both the military and commercial development of the area indicates the expanding national priorities of the period to include both defending the young nation, and expanding commercial and industrial interests. This motion for appropriations passed 151 to $26 .{ }^{166}$ The Army continued to build third system forts in the area, starting construction on Forts McRee, Barrancas, and the Advanced Redoubt, in 1834, 1839 and 1845, respectively. ${ }^{167}$

165 Joseph M. White, "Speech of Mr. White, of Florida on the Naval Appropriations for Pensacola Delivered in the House of Representatives, April 6, 1836," April 6, 1836, U.S. Secretary of the Navy, University of West Florida Archive and West Florida History Center.

${ }^{166}$ Ibid.

${ }^{167}$ Department of the Interior, "The Advanced Redoubt of Fort Barrancas," n.d., Gulf Islands National Seashore Papers Box 4, Folder 3, University of West Florida Archive and West Florida History Center. 


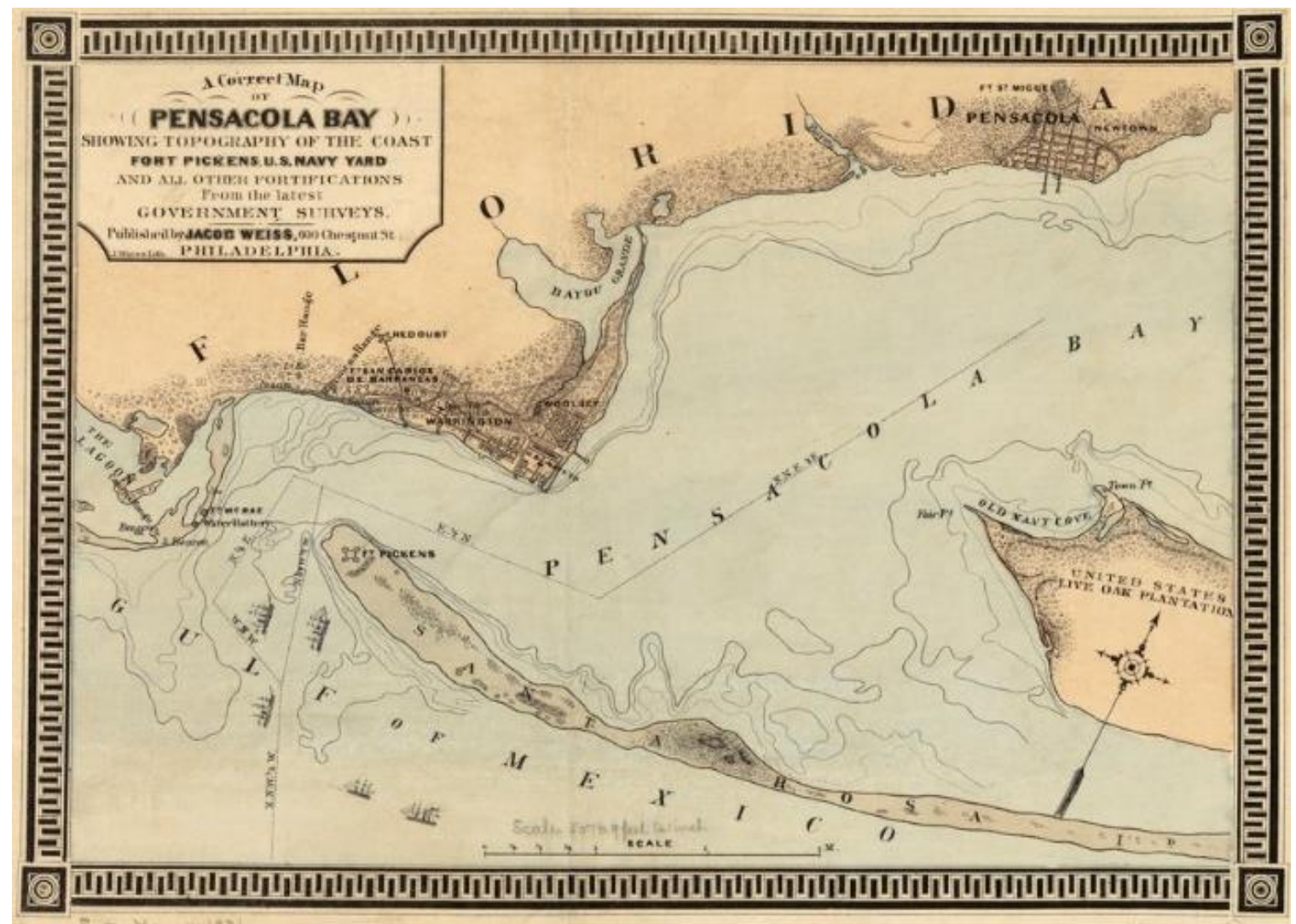

Figure 5. Map of Pensacola Bay, including the Pensacola Naval Yard, 1860-1869.168

In the arguments both for and against the use of Pensacola as an important military installation in the new United States landholdings in the Gulf of Mexico, sand, storms, and climate conditions did not control site construction. The local topography, shape of the bay, prevailing winds, and channel locations, and currents controlled the construction plans of coastal fortifications. ${ }^{169}$ The military officers sent to examine the area for the construction of coastal fortifications did not express concern over hurricanes, but rather, the difficulty and expense of removing sand from

\footnotetext{
168 Jacob Weiss, A Correct Map of Pensacola Bay Showing Topography of the Coast, Fort Pickens, U.S. Navy Yard, and All Other Fortifications from the Latest Government Surveys (Philadelphia, Pennsylvania: Weiss, 1869), Norman B. Leventhal Map Center, Boston Public Library, https://www.digitalcommonwealth.org/search/commonwealth:kk91ft02k.

${ }^{169}$ Emanuel Raymond Lewis, Seacoast Fortifications of the United States: An Introductory History (Washington, D.C.: Smithsonian Institution Press, 1970), 6, 42-53.
} 
the entry to Pensacola Bay. Despite the challenges the moving sand presented, the U.S. Army and Navy prioritized the protection of commercial and Naval construction interests in Pensacola over the environmental challenges in the area. Ari Kelman cites the geographical distinction between "site" as a physical location and "situation" as a combination of advantageous factors to discuss this rationale. ${ }^{170}$ As the U.S. Navy built the Pensacola Naval Yard and the U.S. Army built forts to protect both the Navy Yard, Pensacola Bay, and the approach to New Orleans through the Mississippi Barrier Islands, military managers of Pensacola and the Mississippi-Alabama barrier islands prioritized the relative advantage of location over the any physical volatility of moving sands at the site.

Managers of this military landscape used local climatic conditions to inform some of their choices in building material and their maintenance schedules. In a letter to naval commissioners regarding the construction of docks at Pensacola in 1844, engineer S.D. Dakin suggests that "if the heat of the climate should be regarded as unfavorable to wooden structures at Pensacola, then it might be expedient to build the floating structure at that station." While building at Pensacola was a military priority, climatic patterns contributed to the arrangement of the space. Heavy rains, although deleterious to gunpowder, motivated the Army to maintain roofs and construct more water-tight casks with copper hoops. ${ }^{171}$ When structures were damaged or destroyed by volatile climatic events, the Army made repairs as funds would allow. The U.S. Army rebuilt the wharf at Fort Pickens five times during its period of service from

\footnotetext{
${ }^{170}$ Ari Kelman, “Boundary Issues: Clarifying New Orleans's Murky Edges,” Journal of American History 94, no. 3 (December 2007): 696.

171 "Message from the President of the United States, with a Report from the Secretary of War, Transmitting the Inspection Returns of Brevet Major General Gains, for 1826 and 1827, Relating to the Organization of the Army and Militia," 12.
} 
1828 until 1947, paying more attention to the condition of the wharf in periods leading up to war. The U.S. Army Corps built temporary jetties at Forts McRee and Massachusetts to protect the structures from the encroachment of the sea. ${ }^{172}$ Lewis describes the construction of permanent coastal defensive works as an "elusive ideal," observing that except during times of war, funds and personnel to provide the constant upkeep necessary in the coastal environment were not consistently available or forthcoming. ${ }^{173}$

After the Civil War, the Army declared their disuse of Horn Island in 1874, and their disuse of Cat Island in 1878. Fort McRee, the western-most masonry fort in the triangle defense of Pensacola Harbor was "undermined by the action of the sea to such an extent that much of its scarp [had] fallen down, leaving the casemates open, and it [was] generally in so dilapidated a condition as to be beyond repair, and to possess no value beyond the materials of which it [was] composed." ${ }^{174}$ Neither the sand under Fort McRee, nor the Army's masonry fortresses, nor the military presence on the fringes of the American coastline were permanent. However, the erosion of Fort McRee into the sea did not dissuade federal managers from altering the landscape with permanence in mind, but rather, along with transitioning needs and priorities on the coastline, transformed the expectation of permanence from one of built structures to one of permanent environmental changes that would allow for new military technologies and increasing commercial activity in the area.

\footnotetext{
172 "Annual Report of the Chief of Engineers, United States Army, to the Secretary of War for the Year 1882, Part I" (1882).

173 Ibid., 42.

${ }^{174}$ Chief of Engineers, "Annual Report of the Chief of Engineers to the Secretary of War for the Year 1874,” Pub. L. No. 1 (1874), 25.
} 


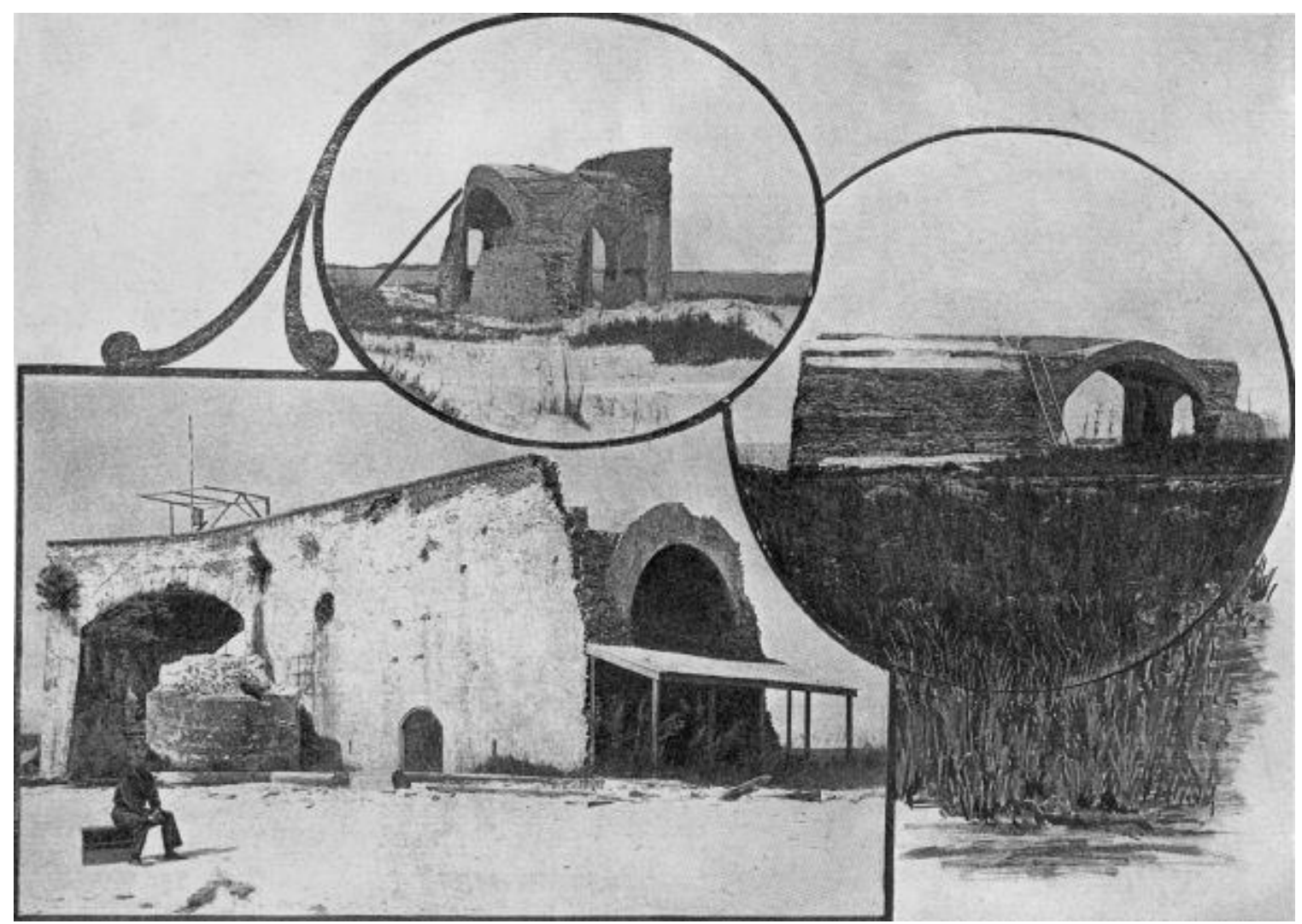

Figure 6. Ruins of Fort McRee, on Perdido Key, $1906 .{ }^{175}$

Although Fort McRee succumbed to the shifting sands and erosive waves, the U.S. Army did not want the land under the fort and the shoreline surrounding the fort to disappear. Military managers no longer emphasized only the permanence of the masonry structures; the U.S. Army needed to maintain the shoreline and coastal areas to construct new batteries. As early as 1848, the U.S. Army Corps constructed temporary jetties of heavy rocks and brush at the former site of Fort McRee to prevent further loss of the shoreline, consistently repairing these jetties over the years when they were damaged by gales. In 1887, the Army Corps requested funds to construct more permanent jetties at Fort McRee, citing that "up to this time the works of shore

175 "Three Views of Ruins of Fort McRee, Florida" (S.H. Kress and Company, 1906), Florida Memory Collection, State Archives of Florida, https://www.floridamemory.com/items/show/140418. 
protection, having been of a tentative character, are perishable, and must be promptly strengthened, or they will be destroyed, with the resulting loss of every advantage gained hitherto. These works are exposed to the action of violent storms from the Gulf, the waves which break upon the shore at this point having great destructive power." ${ }^{176}$ The increasing use of Rodman guns, with longer ranges and more accurate firing trajectories made forts along the coastline unnecessarily vulnerable. In 1885, the Endicott Board recommended new coastal battery systems, leading the Army to install new gun batteries, with cement protections and breech loading cannon. ${ }^{177}$ Workers finished construction on Batteries Cullum, Sevier, Worth, and Pensacola in 1898, modernizing fortifications at the western end of Santa Rosa Island. The Army added Batteries Slemmer and Center to Perdido Key during the same period, building in a more stable location than the original Fort McRee.

In addition to maintaining the shoreline for new military technologies, the U.S. Army Corps wanted to maintain shorelines to lessen the maintenance burdens of dredging Pensacola Harbor. As sand eroded from the Fort McRee area, it shoaled in the dredged channels of Pensacola Bay, increasing the cost of maintenance in the area. ${ }^{178}$ In addition to jetties at Fort McRee to contain sand and reduce shoaling in Pensacola Bay, the Army Corps planned to construct revetments along Santa Rosa Island to "re-establish the old shore line, so far as may be necessary to restore the former direction of the tidal currents." ${ }^{\prime 19}$ However, as the local Army Corps engineers

\footnotetext{
176 "Annual Report of the Chief of Engineers, United States Army, to the Secretary of War for the Year 1887, Part II" (1887), 1270.

${ }^{177}$ Lewis, Seacoast Fortifications of the United States: An Introductory History.

178 "Annual Report of the Chief of Engineers, United States Army, to the Secretary of War for the Year 1890, Part I" (1890), 159.

${ }^{179}$ Chief of Engineers, "Annual Report of the Chief of Engineers, United States Army, to the Secretary of War for the Year 1879, Part I" (1879), 802.
} 
fought to contain the sand of Santa Rosa Island, Perdido Key, and Ship Island, at the national level, the impermanence of the area made Pensacola a disadvantageous location for certain improvements. As steel ships replaced wooden ships, the U.S. Navy required more dry dock facilities to keep the fleet in serviceable condition. ${ }^{180}$ In 1889, the U.S. Navy reported that at Pensacola, "nature has to be assisted in her work of cutting across bars and deepening rivers." ${ }^{181}$ This required maintenance at the site was seen as a disadvantage for expanding the Pensacola Naval Yard; however, the protection of American business interests in the northern Gulf warranted the effort and expense of ongoing dredging efforts.

As technological advances changed the ways in which the U.S. Army used coastal spaces, business and recreation became more dominant uses on the coastal fringes of the Mississippi Barrier Islands, Perdido Key, and Santa Rosa Island. Despite the new batteries and guns on the Pensacola forts, the nature of military use and modification of these coastlines changed during the first half of the $20^{\text {th }}$ century. The U.S. Navy considered the timber trade at Pensacola to be "significant," based on the amount of commerce it generated. In 1878 Congress approved the dredging program for Pensacola Bay under the Rivers and Harbors Act. ${ }^{182}$ The same year, the Army Corps conducted surveys of the Bay and in 1881, Congress appropriated funds to dredge the pass to a depth of 24-feet. ${ }^{183}$ On the national scale, the Army Corps was conducting harbor improvement projects around the country in response to shoaling

\footnotetext{
${ }^{180}$ Ibid., 176.

${ }^{181}$ U.S. Navy, "Report of Navy-Yard Site Commission, Gulf of Mexico and South Atlantic Coasts," 1889, 170, Report of Navy-Yard Site Commission, Gulf of Mexico and South Atlantic Coasts, University of West Florida Archive and West Florida History Center.

182 "Report of the Secretary of the Navy: Plans and Estimates for the Construction of a Permanent Wharf and a Dry Dock at Pensacola," 1844.

183 "Annual Report of the Chief of Engineers, United States Army, to the Secretary of War for the Year 1881, Part I" (1881).
} 
from natural or artificial creation of land. ${ }^{184}$ Publications including Bliss Quarterly and The Pensacolian promoted the growth of the area, hoping to encourage settlement and investment. Starting in the 1880s, the red snapper fishery, based out of Pensacola began to grow into a modern, global industry, spurring the improvement of infrastructure in the area. ${ }^{185}$ With the construction of the Nicaraguan Canal, Pensacola was poised to become a major industrial capital. ${ }^{186}$ The canal would also increase foreign access to the Gulf, thereby increasing the importance of military operations in the area during times of war. ${ }^{187}$ And while the Army Corps would need to dredge the sand in Pensacola Bay,

The aging triangle defenses of Pensacola were located well outside of downtown, and local industrial leaders believed they would enhance, rather than confine the development of the city. During the 1880s and 1890s, the old Spanish Fort San Carlos was already an area of local tourist interest. ${ }^{188}$ The military graded Spanish Fort San Miguel was graded to allow. ${ }^{189}$ The ruins of Fort McRee, advertised as a quaint and beautiful relic, simultaneously highlighted the long American history in the area, the American military presence that would protect the area, and the vast modernization and improvement of Pensacola from the time of historic brick ruins to

\footnotetext{
${ }^{184}$ Michael Rawson, "What Lies Beneath: Science, Nature, and the Making of Boston Harbor," Journal of Urban History 35, no. 5 (July 2009): 679.

185 Jason T. Raupp, "Fish On: Pensacola's Red Snapper Fishery," The Florida Historical Quarterly 85, no. 3 (Winter 2007): 326.

186 "The Port of Pensacola...from the Mobile 'El Commercial Americano,"” Bliss' Quarterly, January 1897, Individual Files, University of West Florida Archive and West Florida History Center.

${ }^{187}$ U.S. Navy, "Report of Navy-Yard Site Commission, Gulf of Mexico and South Atlantic Coasts."

${ }^{188}$ James Roberts Nix, "Shadows of the Past of Pensacola Navy Yard, Old Warrington, Woolsey, Fort Barrancas, Fort Pickens, Fort Redoubt As I Knew Them, Also Here and There," 1966, Individual Files, University of West Florida Archive and West Florida History Center.

189 “Pensacola and Its Environs," Bliss' Quarterly, January 1897, Individual Files, University of West Florida Archive and West Florida History Center.
} 
the thriving, modern city of industry. ${ }^{190}$ Along the Gulf Coast, coastal areas were undergoing a transition from military to other uses. In the same year that Congress considered adding a dry dock to the Navy yard at Pensacola, discussions of Yellowstone National Park were on the docket indicating a rise in conservation concerns. ${ }^{191}$ Management practices in the federal government were also changing with bureaus becoming increasingly professionalized. Scientific prediction of storms was becoming an expectation, as was the public protection of life in the case of storms. ${ }^{192}$ Leading up to the First World War, the U.S. Army continued building new batteries along the coastlines, with batteries Payne, Trueman, and Cooper completed between 1904 and 1906. To protect both these new batteries and old forts, military managers continued with coastal engineering projects to hold the shoreline in place to accommodate changing military technologies and protect shipping channel investments. In the years following this construction, the northern Gulf Coast experienced hurricanes, first in 1906, 1916, and again in 1926. During the 1906 hurricane, the quarantine station at Ship Island was badly damaged, ${ }^{193}$ the Horn Island Lighthouse and Lightkeepers Quarters were destroyed, and the lightkeeper and his family were killed. ${ }^{194}$ Santa Rosa Island fared somewhat better, but still sustained extensive damage. ${ }^{195}$ The magazines, batteries, and fire control station of Fort Pickens

\footnotetext{
${ }^{190}$ Ibid.

${ }^{191}$ U.S. Navy, "Report of Navy-Yard Site Commission, Gulf of Mexico and South Atlantic Coasts."

${ }^{192}$ Raymond Arsenault, "The Public Storm: Hurricanes and the State in Twentieth-Century America," in Paradise Lost?: The Environmental History of Florida (Gainesville, Florida: University Press of Florida, 2005), 201-32.

${ }^{193}$ U.S. Treasury Department, "Estimates of Quarantine Stations in Pensacola,” January 5, 1907, Hurricane Damage at Pensacola, Florida, University of West Florida Archive and West Florida History Center.

194 "Charls Johnsson and Kate Johnsson," Pub. L. No. 6907, § Committee of the Whole House, 1 (1906).

${ }^{195}$ U.S. Treasury Department, "Estimates of Quarantine Stations in Pensacola."
} 
were all flooded and the wharf and railroad were severely damaged. ${ }^{196}$ The hurricane winds and three-meter storm surge inundated the Pensacola Naval Yard, severely damaging many of the structures that were rebuilt after the yard was captured and burned by Confederate troops. The 1906 hurricane also severely damaged vessels near the navy yard seawall ${ }^{197}$ Damages from the 1906 hurricane contributed significantly to the Pensacola Navy Yard shutting down in 1911.

Following the hurricane of 1906, the command of Fort Pickens requested funding for both repairs as well as updates to prevent future damages. ${ }^{198}$ Federal managers focused on retaining land area and protecting the lives of those stationed at the forts through coastal engineering. Following the 1906 storm, the U.S. Army Corps planned to build sea walls around Forts Barrancas and Pickens, completing construction 1910. At Fort Pickens, the Army built additions to buildings in the compound above the hurricane water levels following both the 1906 and the 1916 storms and elevated munition storage in Fort Pickens above the previous hurricane water line. The descriptions of each storm during the aftermath list the cost of replacement for each component demolished during the storm, a practice that continues today. In 1907, the Secretary of the Treasury wrote, "the experience at these forts shows that until sea walls and revetments of sufficient height and strength to withstand the strains produced by storms have been constructed for the protection of the sites there will always be danger of loss of life among the garrisons, of loss of the defensive efficiency of the works, which may even be put out of condition for any

\footnotetext{
${ }^{196}$ U.S. Secretary of the Treasury, "Seawalls at Pensacola Harbor, Florida," January 10, 1907, Individual Files, University of West Florida Archive and West Florida History Center. 197 “\$300,000 Is the Estimated Damage,” The Pensacola Journal, October 5, 1906, 000. ${ }^{198}$ Ibid.
} 
service, and of loss of the garrison buildings, which are rendered uninhabitable by storms and floods." ${ }^{199}$ The 1906 hurricane not only affected the permanence of structures and coastlines, but the military's ability to use their fortified spaces. Federal managers assessed hurricanes as a risk to life and property, but also time and financial cost of replacement. And the solution was additional coastal engineering.

During the First World War, the U.S. Army built Battery Langdon on Santa Rosa Island. The U.S. Navy expanded their presence on the mainland around the former Navy Yard to accommodate new aircraft technology trials, opening the Naval Air Station Pensacola in 1914. These technological innovations required larger, open areas of land rather than military buffers between coastlines and cities. ${ }^{200}$ While the Army continued to construct batteries and update existing works, the military use of the area was starting to wane. In October 1926, a hurricane again struck the Gulf Coast, with the center 25 miles west of Pensacola. This hurricane was especially disruptive for the Gulf Coast, fishing industry, disrupting railroad routes, demolishing piers, and affecting fish stocks and fishing grounds. ${ }^{201}$ The wharves at both Fort Barrancas and Fort Pickens were demolished, making the forts difficult to access. ${ }^{202}$ Following the 1926 hurricane, the pier at Fort Pickens was not reconstructed and was eventually sold and salvaged. ${ }^{203}$ While the Army repaired the coastal fortifications following the 1906 and 1916 storms, the lack of repairs following the 1926 storm

\footnotetext{
${ }^{199}$ U.S. Secretary of the Treasury, "Seawalls at Pensacola Harbor, Florida," January 10, 1907, Individual Files, University of West Florida Archive and West Florida History Center.

${ }^{200}$ Harold E. Balbach and William D. Goran, "The Military Landscape: Why US Military Installations Are Located Where They Are" (Washington, D.C.: U.S. Army Corps of Engineers, March 2011), 10. ${ }^{201}$ Raupp, "Fish On: Pensacola's Red Snapper Fishery," 339.

202 "Hurricane Damage at Pensacola, Fla.," Engineering News-Record, October 14, 1926, Hurricane Damage at Pensacola, Florida, University of West Florida Archive and West Florida History Center. ${ }^{203}$ Brian Mabelitini, "Historical Background of the Fort Pickens Wharf (1828-1947), Santa Rosa Island, FL,” Report of Investigations (Pensacola, Florida: University of West Florida, March 2011).
} 
suggests that the military use of this area no longer warranted attention to structures as important as the pier.

Although maintenance of the Fort Pickens pier and other portions of the military landscape along the northwestern Gulf shore declined in the early $20^{\text {th }}$ century, the Army Corps continued to maintain shipping channels to support industrial development in Pensacola with the Louisville and Nashville Railroad facilities. ${ }^{204}$ By the early $20^{\text {th }}$ century, the channel was 9.75 meters deep and the inner harbor 9 meters. The series of hurricanes starting in 1906 caused sand motion and shoaling, and the bar channel required additional maintenance. ${ }^{205}$ As local business and land developers associated with the Louisville and Nashville Railroad and other local industry continued to encourage people to relocate to the Pensacola area, their pamphlets emphasize the stability of climate, natural setting, fish, and game resources in the area. Authors of "Florida in the Making," written in 1926, argue emphasize "Florida, in short, has always been where and what it is. Its climate has not changed since Ponce de Leon first set foot upon its shores. Its soil is no more productive now than then. Its hills and lakes, its keys and wide-spread beaches, its tropical verdure and its lifegiving sunshine are no different in their essentials than they were before the white man came. ${ }^{206}$

As military managers worked to "aid" nature in her work of cutting dredge channels and bolstered shorelines to fight the natural shift of sands, industrial interests viewed these improvements as features of modernization rather than detracting from the natural setting. Technological improvements including dredging, filling swamps to

\footnotetext{
204 Ibid.

205 "Pensacola Is Going Places," Nautical Gazette 142, no. 6 (June 1948): 20-26.

${ }^{206}$ Stockbridge and Perry, Florida in the Making, 18.
} 
eradicate yellow fever and malaria, and seawalls and revetments along the southern shoreline of Pensacola were not only modernity and development in the city, but part of the cities claim to heritage and status as an international port, with one pamphlet bragging, "Pensacola's reclaimed shoreline made up of red granite from Sweden, blue stone from Italy, broken tile from France, and dredgings from the River Thames and the Scheldes of The Netherlands. ${ }^{207}$ In 1936, the Army Corps proposed improvements to Bayou Chico, a small waterway near downtown Pensacola, to protect fishing vessels and medium size crafts during storms. ${ }^{208}$ Federal managers in the area now turned to protect industrial and recreational boating, transitioning the focus of permanence from the maintenance of coastal fortifications, to coastlines themselves, to the new industrial and recreational uses in the area.

With the Second World War, the range of coastal guns was up to 30 miles and the goal of battery construction was to reduce the number of on-site workers, both due to the declining importance of coastal defenses and the need for labor elsewhere. ${ }^{209} \mathrm{On}$ Santa Rosa Islands, the Army completed Battery 234 in 1943, but did not use the site before the end of the war. The U.S. Army abandoned Cat, Horn, Ship, and Petit Bois Islands in the late $19^{\text {th }}$ century. By the 1940s, private parties purchased Cat Island and the military caretaker of Ship Island had transitioned to the United Daughters of the Confederacy and the Joe Graham American Legion. Horn and Petit Bois Islands were wildlife refuges managed as wildlife refuges by the Fish and Wildlife Service.

Between 1948 and 1950, the military officially turned the coastal batteries on Santa

\footnotetext{
207 "Pensacola Is Going Places."

${ }^{208}$ The Chief of Engineers, "Channel From Pensacola Bay into Bayou Chico, Fla.," Committee on Rivers and Harbors, House of Representatives, April 25, 1936, University of West Florida Archive and West Florida History Center.

${ }^{209}$ Lewis, Seacoast Fortifications of the United States: An Introductory History.
} 
Rosa Island and Perdido Key over to the State of Florida for recreational uses. ${ }^{210}$ And the Army retained Fort Barrancas and the Advanced Redoubt for military use. The area had long been used for recreation by tourists walking on the fort grounds or enjoying the beaches. However, when NPS began purchasing areas of Pensacola and the Mississippi Barrier Islands, the accompanying changes in funding structure and use of space, as well as political developments and shifting scientific understanding in the broader American context, would again change how federal managers in the area expected and engineered permanence in a system of shifting sand.

\section{Installing a National Park amongst Beaches and Forts}

During the late $19^{\text {th }}$ and early $20^{\text {th }}$ century, federal authorities formally converted the military landscapes in Pensacola and the Mississippi Barrier Islands to public or private recreational spaces. Starting in the late 1940s, Americans had more money, time, and access to transportation. The Gulf Coast beaches and forts became more accessible for tourists and recreational fishers, boaters, and swimmers. However, by the 1950s, the State of Florida was struggling with the expense of maintaining Fort Pickens. In the 1960s, Congressman Sikes, the powerful, aggressive, and wellconnected representative of western Florida, championed the creation of a national seashore along Florida's panhandle. In 1966, the U.S. Army Corps submitted a report that found that despite "substantial hazards to life and property from hurricanes, protective structures are not economically justified at the present time." ${ }^{211}$ Despite a recognized risk, the Army Corps determined that the industry of northwest Florida did

\footnotetext{
${ }^{210}$ Lewis, Seacoast Fortifications of the United States: An Introductory History.

${ }^{211}$ Secretary of the Army, "Hurricane Survey of the Northwest Florida Coast," Pub. L. No. House Document No. 459, § Public Works (1966), viii.
} 
not justify federal investment for protection. At the same time, the Congressman Sikes and Congressman Colmer of Mississippi worked with the Bureau of Recreation, the Fish and Wildlife Service, and the National Park Service to conduct a study of the Mississippi, Alabama, and Florida shorelines. A national park became more important to local interests after Hurricane Camille hit in August of 1969. ${ }^{212}$

Although the Army Corps could not justify protective structures, NPS could bring federal repair funds and additional industry to the hurricane-damaged region, or in Congressman Colmer's words, "a much-needed morale and economic boost."213 Hurricane Camille killed 131 people brought storm surges of 5.5 meters, and caused $\$ 1.4$ billion dollars in damage to coastal infrastructure. ${ }^{214}$ Hurricane Camille completely breached Ship Island cutting it into well-defined West Ship Island and lingering sands of East Ship Island. This breach of Ship Island, the assessment of coastal and land permanence following this split, and the plans to "restore" the island that continue today have become emblematic of the new priorities and management goals that NPS has brought to continue the military's fight to engineer permanence in the shifting sands of the northeastern Gulf. As federal managers designed, negotiated and purchased the coastal and submerged lands that would become Gulf Islands National Seashore, managers focused on the permanence of the systems that represented the various uses of the park: maintaining the forts, restoring "natural" habitats and species, and maintaining environmental modifications to allow recreational boating, fishing and other uses. These divergent priorities from previous

\footnotetext{
212 William N. Colmer, "Colmer to Hickel," April 20, 1970, Record Group 79 Records of the National Park Service, Administrative Files, 1949-1971, Box 2745, National Archives, College Park, Maryland. 213 Colmer.

${ }^{214}$ Mark M. Smith, “The Sensory History of a Natural Disaster,” in Camille, 1969: Histories of a Hurricane (Atlanta, Georgia: University of Georgia Press, 2011), 1-20.
} 
site managers did not remove ideas of permanence but changed how managers assessed and engineered permanence into the system.

As NPS designed Gulf Islands National Seashore, they negotiated with state and other coastal owners to gain key and continuous recreational spaces for the park. Initial proposals for the park recommended the chain of islands starting in the west with Chandeleur in Louisiana, through Cat, Ship, Horn, and Petit Bois in Mississippi, Dauphine Island in Alabama and Santa Rosa Island in Florida. However, the State of Louisiana was hesitant to give rights to Chandeleur Island, in part because of a lack of clarity on the ownership of submerged offshore land and resources. In 1969, NPS agreed to remove Chandeleur Island from the plan for GUIS because their "low profile, storm susceptibility, and isolation, and the shallow surrounding waters would prevent extensive public recreational use." ${ }^{215}$ NPS may have wanted to avoid a fight to acquire Chandeleur Island; however, in the text of this concession, NPS indicates a new view towards permanence in the area. The shallow, eroding island was not ideal for public recreational use.

Moving east, Cat Island was excluded from the park until 1999 because the private owners were not interested in selling. The State of Mississippi gave 92-acres of Ship Island to NPS, the park service purchased one acre of Ship Island from the United Daughters of the Confederacy, and negotiated with the Joe Graham American Legion of another 1260 acres. ${ }^{216}$ Horn and Petit Bois Islands were National Wildlife Refuges at the time of park establishment and the Fish and Wildlife Service

\footnotetext{
${ }^{215}$ Secretary of the Interior, "This Letter Is in Reply..."

216 "Meeting of the Gulf Islands National Seashore Advisory Commission, on Tuesday, December 7, 1971, at 11:00 A.m. in the Conference Room of the Secretary of the Interior," December 7, 1971, Gulf Islands National Seashore Papers Box 1, Folder 1, University of West Florida Archive and West Florida History Center.
} 
transferred the islands to NPS. ${ }^{217}$ Dauphine Island in Alabama, once the seat of the French governor, remained a possession of the State of Alabama. The State of Alabama argued for their continuing ownership of the island by suggesting that they did not need assistance in maintaining the cultural resources present at the site. Initial discussions of a park in the area focused on sites in the Pensacola area, and NPS included Perdido Key, including the site of Fort McRee, as well as the western portion of Santa Rosa Island with Fort Pickens in the seashore. On Santa Rosa Island, the National Park Service excluded areas with private development from the park. While the exclusion of the developed area of Santa Rosa Island was based on a variety of legal reasons, this move also suggests that housing developments with modern structures were not appropriate for the new image of the park, emphasizing the view of the area as a recreational space, and grouping historic structures and sites in with this recreational purpose. The negotiations for ownership in these spaces show not only the political process of defining this recreational landscape, but the new management priorities in the area.

Even before NPS officially designated Gulf Islands National Seashore in 1971, the earliest NPS management objectives for national seashores from 1968 focus on the interpretation of the military, natural, and ecological histories. The National Seashore Advisory Committee emphasized the transient nature and physical turnover of barrier island systems. ${ }^{218}$ Engineering and construction in GUIS focused on maintaining many

\footnotetext{
${ }^{217}$ Congress, "Pubic Law 91-660," January 8, 1971, Gulf Islands National Seashore Papers Box 2, Folder 8, University of West Florida Archive and West Florida History Center.

${ }^{218}$ Howard R. Stagner, "Minutes of the 59th Meeting of the Advisory Board on National Parks, Historic Sites, Buildings, and Monuments," December 6, 1968, Record Group 79 Records of the National Park Service, General Correspondence of the Asst Director for Design \& Construction, 1965-1968, Box 1, National Archives, College Park, Maryland.
} 
of the forts the military worked to preserve, as well as recreational spaces on the coastline, and environmental modifications necessary for recreation such as dredged navigation channels, wharves, and harbors at the Mississippi Barrier Islands. Federal park service managers in the area soon became interested in developing wilderness areas in the park. These areas too would require a type of permanence of habitat or natural features. These multi-faceted management goals in an increasingly complicated landscape manifest in efforts to hold structures, shorelines, sand dunes, and species assemblages, at previous state, whether observed or scientifically assessed.

Before Ship Island became a part of GUIS, in 1966, M. James Stevens, Chairman of the Ship Island Committee asked the Bureau of Land Management (BLM) about using sand from dunes on the west end of the island to fill around Fort Massachusetts. BLM rejected this idea arguing that any destruction of natural barriers already present could encourage faster westward turnover of the island. ${ }^{219}$ Their concerns centered both on damaging the fort and light station on Ship Island, as well as causing shoaling in the Gulfport shipping channel immediately west of the island. ${ }^{220}$ BLM did not object to the placement of fill around the fort and emphasized the need for fill at the fort to make the site accessible to the visiting public, but did not want fill to come from protective dunes on the island. Like the strategy employed by military managers in earlier years, BLM recommended engineering the coastline to maintain both the fort, now a recreational destination, and the shipping channel in the area. Just a few years later, NPS management started to focus on the preservation and restoration

\footnotetext{
${ }^{219}$ Julian V. Cox, “Cox to Colmer," September 26, 1966, Record Group 79 Records of the National Park Service, Administrative Files, 1949-1971, Box 1997, National Archives, College Park, Maryland. ${ }^{220}$ Julian V. Cox, "This Is in Response To...," September 26, 1966, Record Group 79 Records of the National Park Service, Administrative Files, 1949-1971, Box 1997, National Archives, College Park, Maryland.
} 
of the forts, including Fort Massachusetts on Ship Island. Newspaper articles printed in the Pensacola area before the creation of the park identified the creation of the national seashore to prevent the imminent loss of sites, especially the forts. ${ }^{221}$ NPS started repair work on Fort Pickens before the park was officially designated and continued after GUIS became a National Seashore in 1971.

However, not all forts were worth preserving. As park planning was underway, NPS Washington recommended that park planning remove Fort McRee from the preservation tasks of the park as the structure had already eroded away. ${ }^{222}$ Although Fort McRee was excluded from the maintenance plan of park, NPS included reconstructed structures. In 1999, the reconstructed frame of the 1886 lighthouse, built by the Ship Island friends group, the Navy helped move the frame to the island. ${ }^{223}$ Lighthouses are built for harsh coastal conditions and subject to technological updates. As such, they are not usually permanent structures. During the $19^{\text {th }}$ and early $20^{\text {th }}$ century, hurricanes and accidental fires destroyed the working lighthouses on Ship Island. The inclusion of reconstructed lighthouses, the reject of ruined structures, and the reconstruction and maintenance of Fort Pickens and the surrounding buildings suggests that NPS managers were trying to reconstruct or maintain the character of the area at a previous time. However, the inclusion of a reconstructed, charismatic lighthouse structure also suggests NPS managers prioritized the construction of a space that visitors to the seashore would enjoy, consistent with the recreational goals

\footnotetext{
221 Joel Gaston, "Proposed Seashore Features Recreation, Beauty, History," November 12, 1967.

222 Advisory Board on National Parks, Historic Sites, Buildings and Monuments, "Summary Minutes of the 54th Meeting Advisory Board on National Parks, Historic Sites, Buildings and Monuments," April 18, 1966, Record Group 79 Records of the National Park Service, General Correspondence of the Asst Director for Design \& Construction, 1965-1968, Box 1, National Archives, College Park, Maryland. 223 "Gulf Islands National Seashore Annual Narrative Report: October 1, 1998 through September 30, 1999."
} 
of the park. Although military managers previously confronted the permanence or impermanence of these coastal structures, NPS managers started to maintain the historic buildings in the area for the new purpose.

The GUIS statement for management of 1980 acknowledges the motion of the environment, referencing sand drift and severe storms as the main drivers of natural change. 224 "Littoral and sand drift to the west and severe storm changes are two natural processes that dominate these dynamic barrier islands and peninsulas. ${ }^{225}$ Despite the open recognition of a changeable environment, shifting barrier islands challenged manager's notions of permanence. During the 1973 meeting of the GUIS Advisory Committee, the site manager for the Mississippi portion of the park described part of Ship Island as "underwater." There is a correct and incorrect place for an island to be. Similarly, managers discussed the Ship Island breach from Hurricane Camille in the 1980 Management Plan, noting "the last time Ship Island was cut this severely it took 100 years to heal."${ }^{{ }^{226}}$ Despite the focus on barrier island change and motion, the idea of healing of a breach as opposed to accepting a new state of being in the park suggests the expectation of a constant state contrary to both the patterns of barrier island motion and the acknowledgement of those patterns in the management literature.

While managers worked to move sand to protect forts and keep islands where they should be, influenced by the growth of the field of ecology and other broad-scale changes, brought different ideas of how permanence should be attained in these

\footnotetext{
224 "Gulf Islands National Seashore Statement for Management," 1980, Gulf Islands National Seashore Papers Box 5, Folder 8, University of West Florida Archive and West Florida History Center.

${ }^{225}$ Ibid., 2.

226 "Gulf Islands National Seashore Statement for Management," 20.
} 
locations. In addition to placing sand, NPS also installed dune fences to encourage sand build up following hurricanes. During the 1980 GUIS Advisory Committee Meeting, "Mr. Mitchell asked regarding the dunes - if they are rebuilt by "Mother Nature," what are the fences for?"227 The response indicated that these fences allowed nature to repair herself. During some years, the Army Corps' sand-moving efforts focused on Perdido Key, which was losing sand more quickly than anticipated due to dredging in the Pensacola Bay channel and creating a sand management plan for Santa Rosa Island. Documents from this period describe the process of placing sand at a site as "stabilizing" the site, which suggests they are trying to hold or maintain a previous or preferred condition. In each of these places, the sand fill is both used directly for beach recreation and to protect historic structures from erosion. Thus, this environmental modification defends two key NPS management priorities.

However, during this period, another management priority emerging from growing ecological research, a focus on natural systems, and the desire to return the environment to a more "pristine," "original," or "natural" state following the industrial development of the mid- $20^{\text {th }}$ century. ${ }^{228}$ During this period, federal managers reintroduced species to the area. In 1986, NPS started a program to re-introduce bald eagles to the park. In 1987, NPS reintroduced the Perdido Key mouse and removed wild pigs from the islands. ${ }^{229}$ The Perdido Key beach mouse disappeared from the area

\footnotetext{
${ }^{227}$ Ibid.

${ }^{228}$ Richard N.L. Andrews, Managing the Environment, Managing Ourselves: A History of American Environmental Policy (New Haven, Connecticut: Yale University Press, 1999).

229 "Gulf Islands National Seashore Superintendent's Annual Narrative Report," 1986, Record Group 79 Records of the National Park Service, Superintendent's Annual Narrative Reports, 1980-2001, Box 28, National Archives, College Park, Maryland.
} 
during Hurricane Frederick. ${ }^{230}$ In 1990, wolves were reintroduced to Horn Island; however, by 1998 NPS removed the remaining wolves as they were eating campers' scraps rather than hunting. ${ }^{231}$ While NPS worked to recreate a past ecological system, features of this system came into direct conflict with the recreational uses of the park.

As NPS decided where to locate facilities within the park, they recommended the Mississippi Islands for different uses based on their elevation, as well as their boating capacities. Horn and Petit Bois Islands would remain wildlife areas without extensive development. However, this use still had recreational value. NPS built boat docks on both islands to allow visitor and manager access to the space. Citizens Wilderness Proposal, a citizen action group lobbied against the construction of a large pier on Horn Island and NPS proposals to allow motor vehicle use on the beaches, plans both inconsistent with the definition of wilderness under the Wilderness Act. Recreation remained the dominant architect on the landscape, despite Horn and Petit Bois Island later receiving wilderness designations, as well as the creation of a new island in the chain using dredge spoils that has since become habitat. This focus on restoring earlier populations suggests NPS managers interpretation of permanence in the barrier environment extended beyond preserving the man-made structures on the coastline or the function of the coastline for recreation or otherwise, but also included

\footnotetext{
${ }^{230}$ F.D. Pridemore, “Annual Narrative Report for Gulf Islands National Seashore," 1984, Record Group 79 Records of the National Park Service, Superintendent's Annual Narrative Reports, 1980-2001, Box 28, National Archives, College Park, Maryland.

231 "Gulf Islands National Seashore 1990 Annual Narrative Report," 1990, Record Group 79 Records of the National Park Service, Superintendent's Annual Narrative Reports, 1980-2001, Box 28, National Archives, College Park, Maryland; "Gulf Islands National Seashore Annual Narrative Report: October 1, 1997 through September 30 1998," 1998, Record Group 79 Records of the National Park Service, Superintendent's Annual Narrative Reports, 1980-2001, Box 28, National Archives, College Park, Maryland.
} 
holding or maintaining a specific natural assemblage and setting on some of the islands and park areas.

However, visitor use and recreation in the park was also causing erosion. When the Gulf Seashore Advisory Committee met in 1973, park managers brought up concerns about visitation in the park causing or enhancing erosion. ${ }^{232}$ Although the Secretary of the Interior at the time, Roger Morton, stated his preference for preservation, he insisted that recreation was the favored use of the public and the park would focus primarily on the development of this use. ${ }^{233}$ However, the visitor preference for recreation began to threaten the manager's preference for preservation of both built structures and pre-existing land areas. Managers worked to reduce visitor-generated erosion by controlling where people were permitted to drive. The Interpretive Prospectus for GUIS, suggests that informing the visitors of the harmful effects of their actions would lessen continuing pressure, as "surely not engage in such activities against his own interests. ${ }^{{ }^{234}}$ However, while visitor activities that disturbed and eroded the land area of the park required action, changes federal managers made to the environment to allow for certain recreational uses were not only conducted but protected.

Erosion caused by visitors was a threat to the permanence of the coastline and managers limited these changes. However, despite the environmental change that occurs during the process, dredging to allow for recreational boating and fishing in the

\footnotetext{
232 “Gulf Islands National Seashore Advisory Committee Meeting," August 2, 1973, Gulf Islands National Seashore Papers Box 3, Folder 4, University of West Florida Archive and West Florida History Center.

233 "Meeting of the Gulf Islands National Seashore Advisory Commission, on Tuesday, December 7, 1971, at 11:00 A.m. in the Conference Room of the Secretary of the Interior."

${ }^{234}$ L. Clifford Soubier, "Interpretive Prospectus: Gulf Islands National Seashore” (Harpers Ferry, West Virginia: National Park Service, February 1979), 3-4.
} 
area was ongoing. In addition to ongoing dredging processes in the area to retain shipping channels into Pensacola, Gulfport, and Biloxi, dredging also included spaces used for recreation. In 1977, dredging to allow recreational boaters to travel from Davis Bayou to Ship, Horn and Petit Bois Islands began. ${ }^{235}$ This project repeated every 3 to 4 years for the next 20 years; however, during the first dredge cycle, funds were instead allocated to make repairs to the Ship Island pier. ${ }^{236}$

During the same period, the focus on access and recreation meant more and better roads within the park. After hurricanes, a lot of effort and attention went to road repairs, heavily modifying the landscape and adjusting how people can access and use the space. After Hurricane Frederick, the park decided to undertake extensive repairs of the roads to Fort Pickens and Perdido Key. To distinguish from post-storm fixes, in 1980 the superintendent of the park describes these repairs as "long-term" and "permanent." ${ }^{237}$ This assessment seems to contradict the extensive record of road repairs following previous storms. The GUIS Advisory Committee planned structures to be inexpensively replaced or able to withstand storm or able to withstand storm over-wash of the island. ${ }^{238}$ Temporary hurricane structures built for the volatile Gulf Coast environment suggest a recognition of impermanence. In 2001, NPS collaborated with the US Forest Service to work on hurricane building construction.

\footnotetext{
235 Paul Winegar, “Park Service Plans to Dredge Davis Bayou Entrance Channel," October 28, 1977, Gulf Islands National Seashore Papers Box 4, Folder 3, University of West Florida Archive and West Florida History Center.

${ }^{236}$ Department of the Interior, "Gulf Islands National Seashore Advisory Commission Meeting," March 15, 1977, Gulf Islands National Seashore Papers Box 4, Folder 3, University of West Florida Archive and West Florida History Center.

237 “Annual Report of the Southeast Region Superintendent for Gulf Islands National Seashore,” 1981, Record Group 79 Records of the National Park Service, Superintendent's Annual Narrative Reports, 1980-2001, Box 28, National Archives, College Park, Maryland.

${ }^{238}$ H. Reese Smith, "Review of Proposed Master Plan, Gulf Islands," November 22, 1968, Record Group 79 Records of the National Park Service, General Correspondence of the Asst. Director for Design and Construction, 1965-1968, Box 34, National Archives, College Park, Maryland.
} 


\section{Shifting Sands for Climate Change Protection}

In the last two centuries, and most dramatically over the last few decades, constant change along the northern Gulf Coast has come to include sea-level rise and other effects of anthropogenic climate change. Based on data from Pensacola and Mississippi tide gauges, a 2004 vulnerability assessment of Gulf Islands National Seashore (GUIS) suggests a sea level rise rate of 40 centimeters per century. ${ }^{239}$ At GUIS, other anticipated changes due to anthropogenic factors include "warming ocean waters, hotter summer temperatures, fewer winter freezes... and higher storm surges. ${ }^{240} \mathrm{~A}$ study produced by Florida State University projects between 13 and 30 centimeters of sea level rise in Pensacola by $2080 .{ }^{241}$ NPS has created storm surge maps for climate adaptation at GUIS which suggest that Santa Rosa Island and the Mississippi Islands may be almost completely inundated by a high tide and high wind storm event. For the cultural resources at GUIS, these changes may translate to more salt water inundation, wind damage, more damage from plant growth, or other factors that may require increased attention to maintain structures in their current condition, or may require more fundamental changes in maintenance.

\footnotetext{
${ }^{239}$ Marguerite A. Toscano, "Assessment of Vulnerability of Coastal Cultural and Archaeological Resources to Sea-Level Rise and Coastal Processes: Gulf Islands National Seashore Florida and Mississippi, Recommendations for Protection and Preservation," Geoscientists-in-the-Parks (Fort Collins, Colorado: National Park Service, 2004).

240 NPS, "Gulf Islands National Seashore Final General Management Plan/Environmental Impact Statement," General Management Plan/Environmental Impact Statement (National Park Service, July 2014), 13.

${ }^{241}$ Julie Harrington and Todd L. Walton, Jr., "Climate Change in Coastal Areas in Florida: Sea Level Rise Estimation and Economic Analysis to Year 2080" (Tallahassee, Florida: The Florida State University, August 2008).
} 


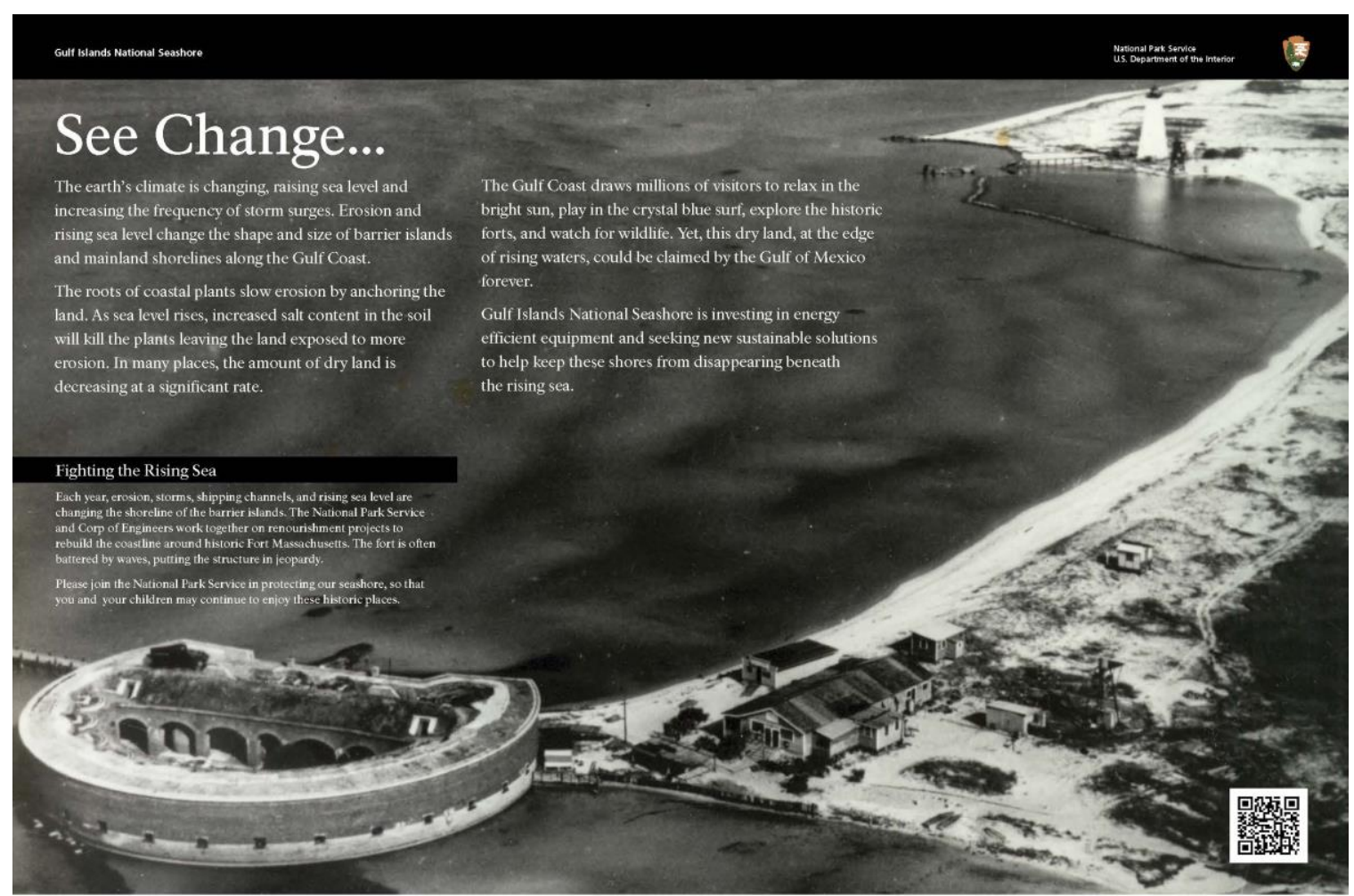

Figure 7. Climate Change Wayside Panel from Gulf Islands National Seashore. ${ }^{242}$

The features of some of the historic structures that past managers built to retain the structures have, in some cases, caused damage to the structures given changing environmental conditions. During hurricanes Ivan in 2004 and Katrina in 2005, the seawall around Fort Pickens retained storm water, damaging the brickwork. Hurricanes or heavy rains can inundate the structure around Battery Sevier at Fort Pickens. Although initially built with gates to release water, during the early $20^{\text {th }}$ century, the Army filled the space between the Fort Pickens seawall and the fort to enhance airflow, effectively burying these gates. At the national level, NPS has put forth a series of policy documents and aids for parks to begin to address the impacts of climate change. In 2014, Director Jarvis of NPS stated that cultural resource managers

\footnotetext{
${ }^{242}$ National Park Service, "Sea Level Change,” National Park Service: Climate Change, January 3, 2018, https://www.nps.gov/subjects/climatechange/sealevelchange.htm.
} 
in parks face "tough choices." And while policies at the national level suggest a changing situation, park managers face change on a range of scales, from repairs on handrails to whether to rebuild after a hurricane. The General Management Plan for GUIS, released in 2014 suggests a new view on environmental change, as visible through the treatment of built resources. Under this plan, parks must protect historic resources, unless managers find that disturbance or natural deterioration are unavoidable. ${ }^{243}$ While the park has lost structures in the past, including Ship Island Lighthouse, this statement indicates a shifting stance on the permanence of the built environment. However, recent management actions suggest that expectations of engineering permanent shorelines and recreational access have yet to change.

Because the primary use of these spaces is recreational, visitor access to sites, in addition to site condition, is of concern to managers. Under military management, the Army moved supplies in and out of Fort Pickens by boat. The State of Florida built the road to Fort Pickens when the area became a state park in the late 1940s. However, sand movement and erosion from storms and hurricanes regularly damage the road. ${ }^{244}$ Following hurricanes Ivan, Dennis, and Katrina, the road was closed for five years repairs, between 2004 and 2009. ${ }^{245}$ In 2009, GUIS released an alternative transportation study and subsequently purchased ferries to transport visitors from Pensacola Beach to the Fort Pickens area. NPS is building the new ferry pier near the historic Army pier and mine storerooms and other historic structures at Fort Pickens

\footnotetext{
${ }^{243}$ NPS, "Gulf Islands National Seashore Final General Management Plan/Environmental Impact Statement," 40.

${ }^{244}$ Dan Brown, "Case Study 19: Establishing Alternative Transportation to Fort Pickens to Supplement Vulnerable Road Access, Gulf Islands National Seashore, Florida," in Coastal Adaptation Strategies: Case Studies, National Park Service Report, NPS 99/129700 (Fort Collins, Colorado: National Park Service, 2015), 46-47.

${ }^{245}$ Landon Stinson, "Future of Fort Pickens Up to Nature," Pensacola New Journal, January 3, 2016.
} 
will be repurposed for recreational purposes. Although managers do not see the road as permanent, the ferry system will continue to allow access to the beach and fort area at Fort Pickens. While a built road structure may not be permanent, managers are working to change a pattern of access to preserve the recreational use of the area. In addition to retaining recreational access, federal managers continue to engineer to maintain islands in a stationary location. In addition to the continuing dredging of Pensacola Pass and shipping lanes into Gulfport and Pascagoula, the Army Corps is in the beginning stages of the Mississippi Coastal Improvements Program (MsCIP) in GUIS. Initiated by the Army Corps in response to a series of strong storms in the early 2000s, culminating with Hurricane Katrina in 2005, MsCIP will restore the breach of Ship Island caused by Hurricane Camille in 1969, for the stated purpose of "[restoring the Mississippi Barrier Islands as part of a comprehensive plan to increase the resiliency of the coast to future storm events." ${ }^{246}$ The Corps asserts that this sand fill will protect cultural resources and restore landforms disturbed by humans. ${ }^{247}$ The Army Corps engineered the coastline of Ship Island to protect Fort Massachusetts starting in the late $19^{\text {th }}$ century and started placing sand around Fort Massachusetts at least as early as 1976. Following Hurricane Frederick in 1980, they placed another 160,000 cubic yards of sand around the fort. ${ }^{248}$ Since then the Army Corps has placed sand in between the fort and the water in 1983, 1999, and 2002, and efforts have continued since then. MsCIP calls for the placement

\footnotetext{
${ }^{246}$ U.S. Army Corps of Engineers Mobile District, "Mississippi Coastal Improvements Program (MsCIP) Comprehensive Barrier Island Restoration Hancock, Harrison, and Jackson Counties, Mississippi: Final Supplemental Environmental Impact Statement" (Mobile, Alabama: Army Corps of Engineers, January 2016), ii.

${ }^{247}$ Ibid.

248 "GUIS Advisory Committee Meeting Minutes," August 8, 1980, Gulf Islands National Seashore Papers Box 4, Folder 3, University of West Florida Archive and West Florida History Center.
} 
of up to 22 million cubic yards of sand in four locations: the area between West and East Ship Islands to reconnect the islands, the east end of Petit Bois Island, the east end of East Ship Island, and the east end of Cat Island. ${ }^{249}$ MsCIP discusses climate change as an accelerating force in the loss of barrier island chains and suggests that given this forcing as well as channel dredging, the MsCIP outcomes will mimic a natural state. Like earlier NPS management strategies, the Army Corps seeks to hold or maintain the previous position of the Mississippi Barrier Islands.

GUIS resource managers, interpreters, and historic preservation experts have all observed changes in the park associated with weather conditions. Managers identified ongoing weathering and deterioration of structures, associated with age and salty, humid environment as the main changes in the system. Despite this emphasis on climate change in the management plan, in interviews, managers were hesitant to link observed changes in the built environment to climate change. While the GUIS General Management Plan emphasizes a change in the approach to permanence in the built environment, purchasing ferries represents a change in patterns of use, rather than a change in how Fort Pickens is maintained or preserved. The MsCIP project suggests that Army Corps managers are focused on the permanence of the barrier islands as a system, and for what they can provide to the coastline of Mississippi more than the geographic position or shape of the island chain. Much like the ongoing change to the islands caused by the dredging of shipping channels through the line of islands, managers are working to retain features of these spaces including recreational space, visitor access, and mainland shoreline protections.

\footnotetext{
${ }^{249}$ MsCIP 2016, 3-3.
} 


\section{Climate Change and a New System of Coastal Defenses in a Military-Transition}

\section{Landscape}

Erosion and motion of sand has long been the dominant feature shaping the development of the northeastern Gulf Coast. The shifting sands have contributed to the political shifts in the area, and motivated managers to work to attempt to outbuild and physically hold the moving environment in place. As managers began to require and demand permanence from a flexible environment, local construction techniques altered to address coastal changes. During the colonial period, Spanish, French, and British authorities noticed the changes in the condition of structures caused by environmental conditions, and although they developed certain technologies to combat environmental changes, they also chose to retreat. When the United States purchased West Florida, the northeastern Gulf became an important strategic military location and the U.S. military built imposing fortifications and engineered coastlines to represent the permanence of their land claims in the area. NPS managers worked to maintain permanence in a shifting environment, but with an expanding set of priorities including the protection of historic structures, recreational spaces, and the restoration of "original" or "natural" ecosystems. NPS policies from Washington and the General Management Plan for GUIS, published in 2014, articulate a new perspective on environmental volatility and climate change; however, these changes need to work with local climate perceptions.

While new management materials published by the Washington office and the park include resource loss as part of the future decision-making process, managers are still working with existing dredging plans and programs to renourish beaches using 
dredge spoil. In addition, at GUIS, managers perceive environmental change as piecemeal through ongoing weathering of forts and structures, as occasionally interrupted by storms and the accompanying sand erosion. While managers presented some contingencies for loss, such as snorkel tours of the forts, there is a disconnect between manager statements and the General Management Plan, meant to be forward thinking, at this point in management. Perceptions of environmental change remain consistent with perceptions from decades past. Managers are working to construct preventative barriers including the MsCIP project and ongoing dredge and fill efforts. While management documents discuss the constant motion and turnover of barrier island systems, the MsCIP project will fill in a natural hurricane breach. Ongoing projects including fill around the forts and on Perdido Key, as well as MsCIP fill suggest that the management priorities and the scale of projects, rather than the approach to shifting sands, have changed. 


\section{CHAPTER 5: "PRESENT, AVAILABLE, OR WHICH CAN BE ACQUIRED BY GRADING AND FILLING:” LEAVING SPACE FOR THE BAY ALONG SAN FRANCISCO'S CONSTRUCTED SHORELINE}

In 1880, the United States Congressional Committee on Private Land Claims worked to resolve an ownership dispute centered on the validity of the U.S. Surveyor General James T. Stratton's 1868 survey of the waterfront of San Francisco. Titleholders to the marshland claimed that the survey placed the high-water mark too far landward, depriving them of additional payments from new owners who invested in improvements on the edge of the land and trailing into the Bay. ${ }^{250}$ The Committee rejected the claims, not on the merits of the survey conducted by the highly-regarded Stratton, but because they believed absolute accuracy in surveying the coastline of San Francisco was "an impossibility." 251 Since the American conquest of San Francisco began in 1846, both "artificial" and "natural" changes to the shoreline created waves, winds, debris, sand, fill, the construction of wharves, and landings obscured the original land-water boundary. ${ }^{252}$ Because of these changes, as well as the considerable financial cost and embarrassment of reversing the 621 deeds granted using the Stratton survey lines, Congress upheld the survey. ${ }^{253}$ And despite the legal difficulties that arose in 1880, San Franciscans would continue to build more city into the Bay, further confusing the boundaries between land and water, decades to come.

\footnotetext{
${ }^{250}$ Pacheco, "Pueblo of San Francisco," Pub. L. No. 1699, § Committee on Private Land Claims, 1 (1880), 2, 9.

${ }^{251}$ Pacheco, Pueblo of San Francisco.

${ }^{252}$ Pacheco.

${ }^{253}$ Pacheco, 9.
} 
The difficulty Stratton and the Committee on Private Land Claims faced in finding the boundary between land and water or natural and urban in San Francisco is not a one-time issue, but part of a longer pattern in the history of the city. Obscured by fog, muddied by salt marshes, eroded by the sea, altered by mining runoff, and filledin by people, the line between natural and urban in San Francisco has long been, and remains, an elusive feature. ${ }^{254}$ Since Spanish explorers arrived at the Golden Gate Strait in the $18^{\text {th }}$ century, the natural features of the San Francisco Peninsula informed construction materials and choices. When Americans began arriving to the area in numbers in the $1840 \mathrm{~s}$, the environment was both intentionally and unintentionally transformed into a new, negotiated space, where the call and response between people and environment instigated dramatic and long-term changes to the bay, coastline and cityscape. As early Spanish managers, the U.S. Army Corps of Engineers, the City of San Francisco, and most recently the National Park Service (NPS) have worked to build the shoreline to accommodate modern needs and priorities, the shape and heritage of the area have changed to reflect these shifting social patterns. Since the 1850s, San Franciscan have filled in portions of the Bay to enlarge their city, contributing to the fuzziness of the line between natural and manmade features, as well as the legal boundaries, industrial spaces, and recreational access points. Today, as San Francisco addresses another combined human-environmental change in the form of climate change and sea level rise, San Franciscans will be challenged to relocate or reshape the boundary between land and water once again.

\footnotetext{
${ }^{254}$ Matthew Morris Booker, Down by the Bay: San Francisco's History Between the Tides (Berkeley, California: University of California Press, 2013), 39.
} 
The spaces along San Francisco's North Beach that house cultural resources and share the maritime history of the city are one part of the equation the city will need to address in climate change planning. Like many of the boundaries in the city, the line between the cultural heritage in North Beach and modern urban structures is obscured by a landscape of complex, overlapping, and changing urban uses. Aquatic Park, Hyde Street Pier, the historic fleet, and even the associated lands of Fort Mason and Fort Point represent both cultural resources, but also a small part of the larger urban seawall and waterfront of a major metropolitan area, with numerous stakeholders. While the location of Aquatic Park, Hyde Street Pier, and the historic fleet are a part of the urban cityscape, these locations represent the outcome of negotiations with both the Bay and a complex urban setting. The cultural resources of this space tell the history of San Francisco; however, the space and structures that house cultural resources are significant and meaningful because of current social, tourism, historic preservation and cultural heritage priorities.

Over the past few decades, climate change has increasingly become a management concern in the Bay Area, as well as within NPS. While all cultural heritage sites have neighbors, park managers in San Francisco are reliant on a seawall and two piers that belong to the City of San Francisco. The landscape of San Francisco is not static, nor maintained in reverence for past or "natural" conditions. The U.S. Government laid claim to the city of San Francisco, aware of the navigational shortcomings of the area, to gain access to the Pacific Ocean. Their subsequent improvements of this area to suit these federal priorities began a cultural legacy of environmental modification in the city. The heritage of San Francisco is one of 
engineering, building, and creating in the face of coupled human-environmental change. Today, cultural resources and cultural heritage are a preservation priority for research, recreational and interpretive values. As park managers work to address climate change, their adaptation options for cultural heritage along San Francisco's coastline will continue a long, complex relationship between various interest groups, as well as built and natural features along North Beach.

\section{'A Safe and Commodious Harbor'}

San Francisco Bay is located on the Pacific Coast of California, 750 kilometers north of the Mexican border and 1250 kilometers south of the Canadian border. The bay system is young, forming only 10,000 years ago when rising sea levels flooded the Golden Gate Strait and filled the drainage basins of the San Joaquin, Sacramento and Coyote rivers. ${ }^{255}$ These rivers carried silt and nutrients into bay waters and moderated ocean salinity. ${ }^{256}$ The various islands in the Bay including Angel Island, Alcatraz, and Yerba Buena are all flooded hills. The San Francisco Bay Area has a Pacific climate characterized by frequent fog, moderate temperatures, and moist air. ${ }^{257}$ The Golden

Gate Strait, where the bay meets the ocean, is 3 kilometers wide and 100 meters deep. The remainder of the Bay is shallow, less than 3 meters deep in many places. ${ }^{258}$ The Bay has two arms: South Bay extending in the same direction, and another arm extending west towards gold country and the Sierra Nevada mountains, encompassing

\footnotetext{
${ }^{255}$ T.J. Conomos, R.E. Smith, and J.W. Gartner, "Environmental Setting of San Francisco Bay," Hydrobiologia 129, no. 1 (October 1985): 1-12.

${ }^{256}$ Ibid.

${ }^{257}$ Ibid.

${ }^{258}$ Harold B. Goldman, "Geology of San Francisco Bay," Geologic and Engineering Aspects of San Francisco Bay Fill (San Francisco, California: California Division of Mines and Geology, 1969).
} 
the smaller Suisun and San Pablo bays. Salt marsh systems and fertile farmland surround these bays. In addition, a dominant feature of the area is the San Andreas fault system, which includes numerous active earthquake fault zones, running parallel up the length of California. Once the surface of the bay was 2100 square kilometers, but today, the bay has been reduced to about 1500 square kilometers, salt marshes have decreased to a quarter of their original extent and many of the rivers that run into the bay have been dammed. ${ }^{259}$ The modern extent of San Francisco Bay is surrounded on all sides by growing urban centers and in total, over 7 million residents.

People have inhabited the San Francisco area for at least 5,000 years. Before the Spanish arrived in the area, 50 Ohlone and 14 Coast Miwok tribes moved seasonally along the coasts of the San Francisco Peninsula and the North Bay. These societies supplemented the stable supply of local shellfish with seasonal hunting, fishing, and gathering and managed land areas with periodic burns. ${ }^{260}$ Spanish and English explorers first traveled along the coast of Northern California in the area in the mid- $16^{\text {th }}$ century. In the mid- $18^{\text {th }}$ century, Spanish settled in the area to lay prevent Russian encroachment on their territory and to expand religious influence. ${ }^{261}$ In 1769 , an advance party of Spanish soldiers from Don Gaspar de Portolá's expedition, led by Sergeant José Ortega, continued past Monterey and spotted the Golden Gate strait and

${ }^{259}$ M. Goman, F. Malamud-Roam, and B.L. Ingram, "Holocene Environmental History and Evolution of a Tidal Salt Marsh in San Francisco Bay, California," Journal of Coastal Research 24, no. 5 (September 2008): 1126-37; Ariel Rubissow Okamoto and Kathleen M. Wong, Natural History of San Francisco Bay, California Natural History Guides (Berkeley, California: University of California Press, 2011), 6.

${ }^{260}$ Booker, Down by the Bay: San Francisco's History Between the Tides, 21; N.C. Nelson, "Shellmounds of the San Francisco Bay Region," University of California Publications in American Archaeology and Ethnology 7, no. 4 (1909): 310-46; Edward M. Luby, Clayton D. Drescher, and Kent G. Lightfoot, "Shell Mounds and Mounded Landscapes in the San Francisco Bay Area: An Integrated Approach," The Journal of Island and Coastal Archaeology 1, no. 2 (2006): 191-214, https://doi.org/10.1080/15564890600935365.

${ }^{261}$ John Phillip Langelier and Daniel Bernarn Rosen, "Historic Resource Study: El Presidio de San Francisco, A History under Spain and Mexico, 1776-1846” (National Park Service, August 1992). 
the San Francisco Bay. Scouting missions led by Captain Juan Agustín Bautista de Anza by land and Brune de Hezeta, Juan Francisco de la Bodega y Quadra, and Juan Manuel de Ayala by sea determined that both the land and harbor were fit for settlement with good anchorage, water supplies, and other resources. ${ }^{262}$ These early observers of San Francisco describe the area as cold and foggy but giving way to "safe and commodious harbors."263

In 1776, with authority from the King of Spain and a small party of explorers, Captain Juan Bautista de Anza reached modern-day San Francisco and selected a location for the Spanish Presidio on the northern shore of the San Francisco Peninsula, where the Spanish garrison would be able to monitor and defend Golden Gate Strait. ${ }^{264}$ A member of Anza's party, Friar Pedro Font, was confident that "the new establishment can obtain plenty of firewood, water and pasture for the horses all near at hand, and nothing is wanting but timber for large buildings." 265 Timber was available, but six leagues away. Friar Font also noted the plentiful salmon Native Americans caught using nets. ${ }^{266}$ The Viceroy of Alta California encouraged Juan Bautista de Anza to establish missions in the area and other signs that claim the land

\footnotetext{
${ }^{262}$ Langelier and Rosen.

263 “Relacion De Teperamento 1785," 1785, Carton 21, Folder 18, San Francisco, Bancroft Reference Notes for California, [ca. 1870-1890], Bancroft Library, University of California, Berkeley, California; Henry Augustus Wise, Los Gringos, or, An inside View of Mexico and California, with Wanderings in Peru, Chili, and Polynesia (New York City, New York: Baker and Scribner, 1849), 70; Frederick William Beechey, Narrative of a Voyage to the Pacific and Beering's Strait, to Co-Operate with the Polar Expeditions: Performed in His Majesty's Ship Blossom, under the Command of Captain F.W. Beechey in the Years 1825, 26, 27, 28 (London: H. Colburn and R. Bentley, 1831).

264 "How the Bay City Was Founded One Hundred Years Ago," San Francisco Post, May 20, 1876, Carton 16, Folder 11 San Francisco, Bancroft Reference Notes for California, [ca. 1870-1890], Bancroft Library, University of California, Berkeley, California.

265 "How the Bay City Was Founded One Hundred Years Ago."

266 "How the Bay City Was Founded One Hundred Years Ago."
} 
for the Spanish monarch. ${ }^{267}$ In 1776, José Joaquín Moraga led 193 settlers back to the area to build a presidio at the site identified by Anza. ${ }^{268}$

While Anza had selected the current presidio site for its strategic advantage, Moraga found this area foggy and windy and preferred to establish the Presidio in a more sheltered. However, regardless of location, the structures built at the Presidio suffered in the San Francisco climate. The soldiers built adobe structures with thatched roofs from the local Tule reeds. The thatched roofs were hard to maintain, with risk of fire during the spring and summer, damp and rot in the winter, and wind damage yearround. ${ }^{269}$ The thick and persistent fog that many early observers of the Bay noted made it difficult for the soldiers to construct and maintain their built environment. Josef Arguello, Commander of the Presidio, reported that constant storms and winds required the soldiers to repair their thatched roofs at least annually. ${ }^{270}$ In a letter to the Viceroy of New Spain, an officer at the Presidio blamed the poor status of the structures on poor workmanship, humidity, and the closest source of timber being at least 10 leagues away. ${ }^{271}$ By 1794, the governor reported the walls of the bastion were made of "brick and lime facings, so that the rains may not hurt them." "272 Many of the observers in early Spanish San Francisco noted the changeable weather and the bad

${ }^{267}$ Langelier and Rosen, "Historic Resource Study: El Presidio de San Francisco, A History under Spain and Mexico, 1776-1846."

${ }^{268}$ Langelier and Rosen.

269 "March 4 1792- Sal to Roman He Encloses a Plan of Presidio (with Explanation)," March 4, 1792, Carton 16, Folder 13, San Francisco, Bancroft Reference Notes for California, [ca. 1870-1890], Bancroft Library, University of California, Berkeley, California.

270 “Arguello to Berica," July 20, 1797, Carton 16, Folder 14, San Francisco, Bancroft Reference Notes for California, [ca. 1870-1890], Bancroft Library, University of California, Berkeley, California. 271 "March 4 1792- Sal to Roman He Encloses a Plan of Presidio (with Explanation)."

272 "Gov to VR," June 12, 1794, Carton 16, Folder 13, San Francisco, Bancroft Reference Notes for California, [ca. 1870-1890], Bancroft Library, University of California, Berkeley, California; "Comnte to Govr," November 1, 1794, Carton 16, Folder 13, San Francisco, Bancroft Reference Notes for California, [ca. 1870-1890], Bancroft Library, University of California, Berkeley, California. 
winter storms which led to the destruction of the adobe walls. ${ }^{273}$ Certain years or periods of multiple years brought a series of harsh storms and fog was a part of both the summer and winter weather patterns. ${ }^{274}$ On November $26^{\text {th }}, 1804$ a storm blew down the palisades of the Battery of Yerba Buena and damaged Fort San Joaquin. ${ }^{275}$ By 1810, Arguello wrote to the Governor that the storms were continuous and the buildings at Fort San Joaquin were in a deplorable state or destroyed completely. As Mexico fought for independence from Spain, repairs to frontier structures in Alta California seem to have drawn little attention until the official transfer to Mexico in 1821. Under Mexican rule, much of the activity and construction in San Francisco moved to Yerba Buena Cove, on the more protected northeast corner of the peninsula. The early 1820s were flood years in San Francisco and around the Pacific Basin and amidst the storms, Mexican officials gave permission for ships to anchor at Yerba Buena rather than other points along more dangerous points on the northern coast of the peninsula. ${ }^{276}$ Mexican rule over California relaxed compared with Spanish domination and otter pelt trade with Russian merchants began in San Francisco in the

273 "Govr to VR," July 18, 1806, Carton 16, Folder 16, San Francisco, Bancroft Reference Notes for California, [ca. 1870-1890], Bancroft Library, University of California, Berkeley, California. 274 "Commndr Josef Arguello Annual Report to Govr," n.d., Carton 16, Folder 15, San Francisco, Bancroft Reference Notes for California, [ca. 1870-1890], Bancroft Library, University of California, Berkeley, California.

275 "Comd Arguillo to Gov.," November 29, 1804, Carton 16, Folder 16, San Francisco, Bancroft Reference Notes for California, [ca. 1870-1890], Bancroft Library, University of California, Berkeley, California.

276 “S Fco Was Not Changed...," 1823, Carton 16, Folder 18, San Francisco, Bancroft Reference Notes for California, [ca. 1870-1890], Bancroft Library, University of California, Berkeley, California; Admiral Otto von Kotzubue, “A Memorable California Winter," San Francisco Bulletin, January 11, 1867, Carton 21, Folder 18, San Francisco, Bancroft Reference Notes for California, [ca. 1870-1890], Bancroft Library, University of California, Berkeley, California; "Sub. Commisio to Gov," July 27, 1833, Carton 17, Folder 1, San Francisco, Bancroft Reference Notes for California, [ca. 1870-1890], Bancroft Library, University of California, Berkeley, California. 
1820s. ${ }^{277}$ From 1824 until 1826, earthquakes further damaged the weathering structures as the military outpost, toppling cracked adobe walls. ${ }^{278}$ By the 1830 s, Spanish and Mexican settlers had established 25 ranches and 17 haciendas around the San Francisco Bay spanning from across the Golden Gate in Sonoma to modern San Jose in the south bay. With these new settlements, the volatile winter storms and intrusive fogs of San Francisco, and the challenge of maintaining structures therein, led Mexican officials to discuss the relocation of the fortifications at San Francisco to Angel Island in $1839 .{ }^{279}$ By the end of 1830 s, most of the town of San Francisco had moved alongside Yerba Buena Cove, including the shop established there by American trader Jacob Leese in $1836 .^{280}$

The American presence in Mexican San Francisco grew from the late 1830s through the early 1840 s, contributing to tensions building up to the Mexican-American War. In 1846, a small group of Americans claimed California as an independent republic, raising the bear flag and providing the waiting U.S. Navy reason to occupy and claim San Francisco the area. ${ }^{281}$ The Treaty of Guadalupe Hidalgo in 1848 officially transferred western lands spanning from modern New Mexico and Colorado west to California to the United States. Within years of the American purchase of

\footnotetext{
277 A.S. Taylor, "Influence of California Climate on Animal Life Pt. 1," San Francisco Bulletin, December 8, 1856, Carton 21, Folder 18, San Francisco, Bancroft Reference Notes for California, [ca. 1870-1890], Bancroft Library, University of California, Berkeley, California. 278 "Don Salvio Pacheco an Old...," Trinity Journal, March 26, 1864, Carton 21, Folder 18, San Francisco, Bancroft Reference Notes for California, [ca. 1870-1890], Bancroft Library, University of California, Berkeley, California.

279 “Dec. 6 1839," December 6, 1839, Carton 17, Folder 1, San Francisco, Bancroft Reference Notes for California, [ca. 1870-1890], Bancroft Library, University of California, Berkeley, California.

280 T.H. Watkins and R.R. Olmsted, Mirror of the Dream: An Illustrated Hisotry of San Francisco (Oakland, California: Scrimshaw Press, 1976), 14.

${ }^{281}$ Neal Harlow, California Conquered: The Annexation of a Mexican Province, 1846-1850 (Berkeley, California: University of California Press, 1982); "Report of the House Committee on the Santillan Claim," Washington Post, March 5, 1878, Carton 5, Folder 5 Land: San Francisco, Bancroft Reference Notes for California, [ca. 1870-1890], Bancroft Library, University of California, Berkeley, California.
} 
California, immigration to San Francisco would completely transform the city, coastline, and the way in which the inhabitants both engineered and responded to environmental change on the peninsula. ${ }^{282}$

\section{Fixing-up a Rocky Bay and a Foggy Peninsula in a Great Location}

While early Spanish observers were pleased with the sheltered expanse of San Francisco Bay, but early American surveyors in the area were less impressed with the Bay, complaining of rocky outcropping and difficult navigation. In addition, Americans were also challenged by the foggy conditions in the Bay which obscured land and water, and made the climate on the peninsula cold and damp. However, the value of the San Francisco Bay, for the new American owners, was in the location rather than the environmental features. The United States presence in the Bay represented a milestone in Westward Expansion and an American headquarters for access to Pacific trade routes and commercial connections. The advantages of the location outweighed the site itself. ${ }^{283}$ And this advantageous site would only be enhanced by the discovery of gold in the nearby foothills of the Sierra Nevada mountains in 1848. Within years of American acquisition of the city, residents began building piers into the Bay, filling portions of the Bay to create more land away from the foggy Pacific coastline, leveling sand hills on the peninsula, filling marshes to make ships with deep berths more accessible, and even importing shellfish to make

\footnotetext{
${ }^{282}$ S.W. Kearny, "Sir: Your Letter of The...," April 19, 1847, Carton 5, Folder 5 Land: San Francisco, Bancroft Reference Notes for California, [ca. 1870-1890], Bancroft Library, University of California, Berkeley, California; John Haskell Kemble, San Francisco Bay: A Pictoral Maritime History (New York City, New York: Bonanza Books, 1978).

${ }^{283}$ Ari Kelman, "Boundary Issues: Clarifying New Orleans's Murky Edges," Journal of American History 94, no. 3 (December 2007): 695-703.
} 
menus more familiar to American palates. Much like the election of the Board of Commissioners of San Francisco Bay, who's job would become ensuring the bay fill stay in place, the early American responses to the foggy San Francisco Bay environment would become enshrined and expected practice and guide the relationship between people and the environment for decades to come.

In 1846, Berthold Seemann, writing for the Seaman's Herald found the Bay of San Francisco disappointing, saying it is an inland sea more than a harbor and the rivers that enter the bay "cause rapid tides and numerous shoals, so that its depth of water is not commensurate with the extent of the bay." ${ }^{" 284}$ Seemann does, however, identify the northern portions of the Bay as superior in terms of water depth and Yerba Buena as the best anchorage in the Bay. ${ }^{285}$ Three years later, Captain Ringgold mapped the area for the U.S. Navy and similar to Seemann, found the Bay to be unnavigable even for steamers, due to many shallow rock formations. ${ }^{286}$ However, by the 1840s, the United States had an established history of harbor improvements. Twenty-five years earlier, Congress passed the first Rivers and Harbors Act and shoal removal and dredging operations were underway in certain bays and harbors. San Francisco represented a measure of success in westward expansion and access to Pacific commercial dealings. Despite these reports of the less-than-perfect navigational conditions in the Bay the United States invested resources and attention in the area and the city grew.

\footnotetext{
${ }^{284}$ Berthold Seemann, "Seemann's Voyage of the Herald, Volume 1," September 18, 1846, 113, Carton 17, Folder 5, San Francisco, Bancroft Reference Notes for California, [ca. 1870-1890], Bancroft Library, University of California, Berkeley, California.

${ }^{285}$ Seemann, 113.

${ }^{286}$ W.H. Smythe, "Address of Captain W.H. Smythe" (Journal of the London Geographical Society, n.d.), Carton 2, Folder 22, Discovery and Exploration 1636-1843, Bancroft Reference Notes for California, Bancroft Library, University of California, Berkeley, California.
} 
In 1847, the Military Governor of California, Stephen W. Kearny received a request from William S. Clarke to build a public wharf of "50 varas fronting on Battery Street, extending as far into the water, with the rights for this place to belong to his heirs forever." 287 Twenty years later, San Francisco Magazine Olden Time recalled many San Francisco residents found a wharf into deep water, especially one costing $\$ 2,000$ to construct, to be a great extravagance, since a similar wharf in Monterey had been destroyed by a storm. ${ }^{288}$ However, the potential commercial benefit of this wharf outweighed the environmental risk. During the same year, Governor Kearny selected choice lots along the eastern waterfront of the city for the U.S. Army and Navy to use and for the construction of a customs house. ${ }^{289}$ Once choice lots were set aside for federal agencies, the remaining beach and water lots between Fort Montgomery and Rincon were given for public auction. ${ }^{290}$ The remodeling of the San Francisco waterfront had begun.

Between 1846 and 1849, the population of San Francisco increased from 200 to 25,000. ${ }^{291}$ Geographers including Gunther Barth and Brian Godfrey described the accompanying environmental transformation of the city from a growing trade port to

\footnotetext{
${ }^{287}$ Vara is the Spanish yard, which retained use in California as it was the system with which distances in Mexican California were initially measured. A vara is slightly shorter than an English yard, measuring approximately 33 1/3 inches or 85 meters, see "Ante-Pioneer Days: A Few Relics of Mexican Occupancy of California," San Francisco Chronicle, November 6, 1877, Carton 17, Folder 1, San Francisco, Bancroft Reference Notes for California, [ca. 1870-1890], Bancroft Library, University of California, Berkeley, California; Kearny, "Sir: Your Letter of The..."

288 "The Olden Time," Californian, September 30, 1871, Carton 18, Folder 1, San Francisco, Bancroft Reference Notes for California, [ca. 1870-1890], Bancroft Library, University of California, Berkeley, California.

${ }^{289}$ S.W. Kearny, “Appendix No. 10,” March 10, 1847, Carton 5, Folder 5 Land: San Francisco, Bancroft Reference Notes for California, [ca. 1870-1890], Bancroft Library, University of California, Berkeley, California; W.T. Sherman, "Headquarters Tenth Military Department," June 23, 1847, Carton 5, Folder 5 Land: San Francisco, Bancroft Reference Notes for California, [ca. 1870-1890], Bancroft Library, University of California, Berkeley, California. ${ }^{290}$ Sherman, "Headquarters Tenth Military Department."

291 "From the 1820s to the Gold Rush," The Virtual Museum of the City of San Francisco, accessed October 5, 2017, http://www.sfmuseum.org/hist1/early.html.
} 
the urban gateway to the California hills as the creation of an "instant city." 292 The sand hills observed by early visitors to the city had been levelled and this sand, as well as ships and other materials, were used to fill in the small coves flanking the city. San Franciscans filled and armored tidal areas, claiming any shallow coastal space for people and business. ${ }^{293}$ Merchants and others built wharves into the Bay to facilitate shipping and trade and ships that were once in the Bay, but sometimes found city streets building to the edges of their wharves or beyond their wharves, into the water. ${ }^{294}$ In 1849 , observers noted that the tides ran up Montgomery, Sandsome and Kearny streets. ${ }^{295}$ However, the location of the tides had not changed, but the streets were built into the Bay. Compounding the challenges of the quick gold rush growth, the winters of 1849 and 1850 were particularly stormy years, increasing the flooding on the partially built streets. ${ }^{296}$

\footnotetext{
292 Brian J. Godfrey, "Urban Development and Redevelopment in San Francisco," The Geographical Review 87, no. 3 (July 1997): 309-33; Gunther Barth, Instant Cities: Urbanization and the Rise of San Francisco and Denver (New York City, New York: Oxford University Press, 1975). 293 "In 1850 the Bay Of...," 1850, Carton 17, Folder 11, San Francisco, Bancroft Reference Notes for California, [ca. 1870-1890], Bancroft Library, University of California, Berkeley, California. 294 "In 1850 the Bay Of..."

295 "The Narrator Landed at San Fco," October 1849, Carton 17, Folder 8, San Francisco, Bancroft Reference Notes for California, [ca. 1870-1890], Bancroft Library, University of California, Berkeley, California.

296 "Diary of a Forty-Niner," December 14, 1849, Carton 17, Folder 10, San Francisco, Bancroft Reference Notes for California, [ca. 1870-1890], Bancroft Library, University of California, Berkeley, California; “The Rainy Season Was Now...," 1849, Carton 17, Folder 10, San Francisco, Bancroft Reference Notes for California, [ca. 1870-1890], Bancroft Library, University of California, Berkeley, California. "The rainy season was not at its height--that ever-to-be-remembered fall and winter of 18491850--and the streets were simply awful! Awful is a mild term, but I ain't just now call to mind a more expressive adjective. They ran rivers of mud, and swallowed up every living thing that attempted to cross them. Waterproof suits and cavalry or long boots were in great demand, and commanded Munchausenistic prices. It was no uncommon occurrence to see at the same time a mule stalled in the middle of the street with only his head above the mud, and an unfortunate pedestrian who had slipped off the plank sidewalk, being fished out by a companion. Some good Samaritan, with a heart overflowing with the milk of human kindness, erected at the corner of Clay and Kearney streets the following warning to the unwary: This street is impassable, not even jackassable!"
} 


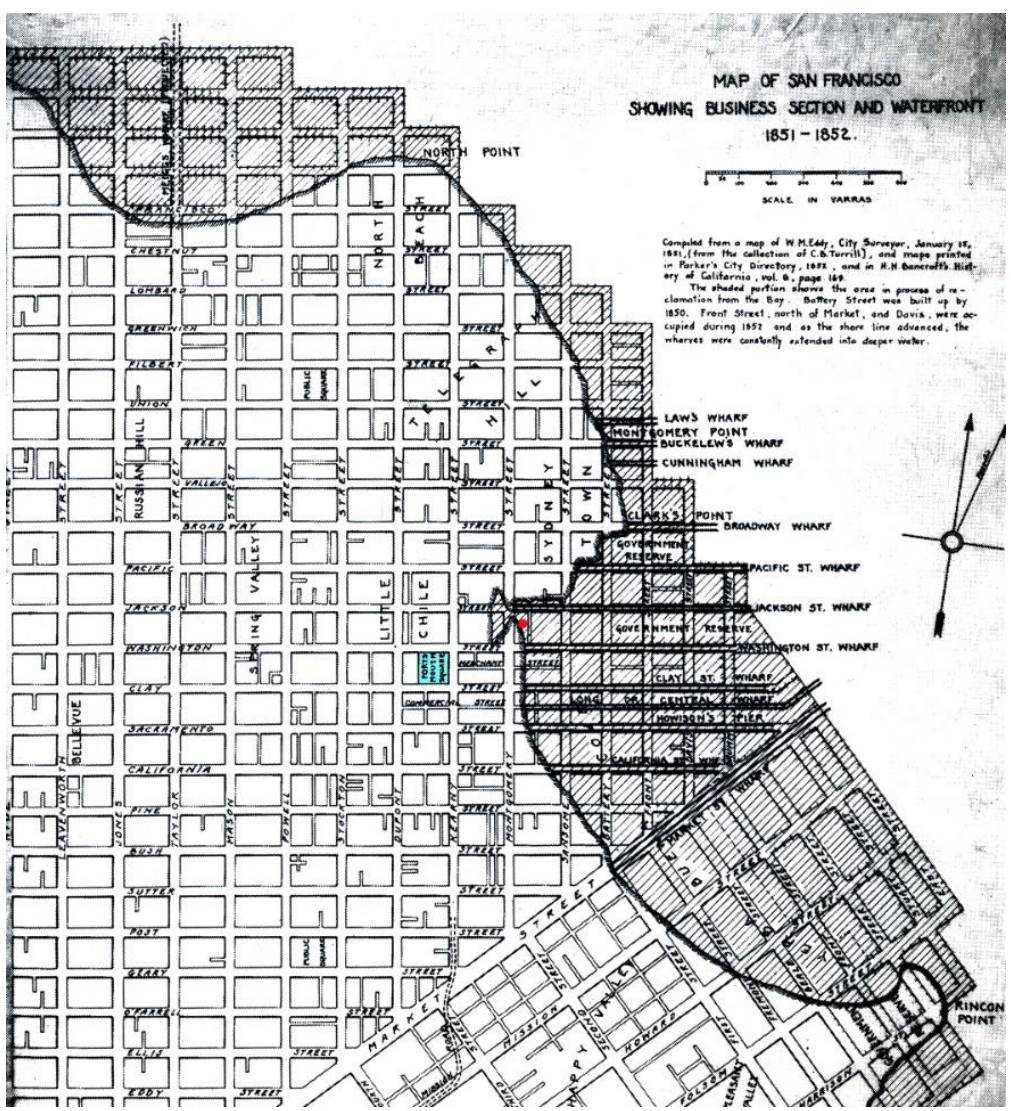

Figure 8. Map of San Francisco in 1851 showing the original shoreline and the water-covered lots sold by city officials. ${ }^{297}$

While San Franciscans added space to their growing city by building into the Bay, complicating the boundary between water and land, this ongoing cultural negotiation with the environment was not the only factor that contributed to the constant environmental change of the city. Ships entering the harbor often delayed by the foggy conditions. Much like the technological developments that were changing the shoreline, federal managers added pilots, fog guns, and eventually bell boats, to the harbor to aid navigation in foggy conditions. ${ }^{298}$ Additionally, the city frequently

\footnotetext{
297 “John Coffee Hays: San Francisco's First Elected Sheriff," History of the San Francisco Sheriff's Department, accessed October 8, 2017, http://www.sfsdhistory.com/eras/john-coffee-hays-sanfranciscos-first-elected-sheriff.

${ }^{298}$ Frank S. Brown, "Voyage to San Francisco and the Port of Boston in the Ship Masconomo," 1853, Frank S. Brown Papers, San Francisco Maritime Research Library; Kemble, San Francisco Bay: A Pictoral Maritime History.
} 
burned, and San Franciscans equally frequently rebuilt, creating a cyclical and risky atmosphere in the city. ${ }^{299}$ This, compounded with storms, long term sea level rise, and mining runoff changing depth and salinity of the Bay, all contributed to San Francisco being a system where change, rather than stasis, was endemic. ${ }^{300}$ By 1851 , maps drawn of the northeastern waterfront of San Francisco were noticeably different from the environment just five years earlier. ${ }^{301}$ The profile of the city, especially the northeastern shoreline had already extended with early fill and wharf construction. Unlike the slow, landward build-up of contemporary western frontier towns, San Francisco evolved, almost overnight, as a maritime city. ${ }^{302}$

While eager miners and shrewd business minds contributed to much of the development of San Francisco, the United States government had plans and priorities for the city from the beginning, and contributed to the shaping of the waterfront. Congressional plans for San Francisco revolved around East Asian trade and military defense. In 1851, Congress discussed plans to regulate trade with China and in 1852 , Congress appropriated $\$ 400,000$ for a customs house in the city. During the same year, Congress appropriated $\$ 500,000$ for the construction of military fortifications in the area which would both protect American claims in San Francisco, and support American Naval, whaling, and trade vessels in the Pacific. ${ }^{303}$ These fortifications

\footnotetext{
299 John Doe, "Sacramento During the Last Twenty Years," 1852, Carton 17, Folder 11, San Francisco, Bancroft Reference Notes for California, [ca. 1870-1890], Bancroft Library, University of California, Berkeley, California.

${ }^{300}$ Booker, Down by the Bay: San Francisco's History Between the Tides, 39.

${ }^{301}$ John Haskell Kemble, San Francisco Bay: A Pictorial Maritime History (New York City, New York: Bonanza Books, 1978).

302 James Delgado, Gold Rush Port: The Maritime Archaeology of San Francisco's Waterfront (Berkeley, California: University of the West Indies, 2009), 4.

${ }^{303}$ Frederick P. Stanton, "Steamers Between California and China," Pub. L. No. 34, § Committee on Naval Affairs, 1 (1851); Secretary of the Treasury, "New Custom-Houses," Pub. L. No. 64, § House of
} 
would include a Navy dry dock to be built on the east coast and towed around Cape Horn. ${ }^{304}$ The Army installed gun batteries on Alcatraz Island to protect the entrance to the Bay through the Golden Gate Strait. ${ }^{305}$ While the Gold Rush was short lived, with the boom receding by 1853 and 1854 , Congressional appropriations and military construction show that Congress had much longer term plans for the city. And with Congressional support for trade, railroad construction, and various supporting industries, San Franciscans continued instigating and adapting to environmental change as the city grew.

In 1853, the City of San Francisco passed an ordinance to sell lots that were covered in up to 7.5 meters of water at low tide along the eastern shore of the city. ${ }^{306}$ This project was considered "a wise and proper one" because as the wharves on Sacramento, Commercial, and Clay streets were built out, San Franciscans would have filled the lots anyways, had the city not sold them. ${ }^{307}$ Observers who witnessed the town in 1849 and 1850, and returned in the 1870 s noted that the "much of the city, now handsomely built over, has that old marsh lying below it, buried deep beneath the sand. The sand hills were removed and cast into and upon that marsh." ${ }^{308}$ Many of the original wooden and cloth buildings were rebuilt in stone. ${ }^{309}$ In 1878 , an observer who

Representatives, 1 (1852); Secretary of the Navy, "Report of the Secretary of the Navy," Pub. L. No. 44, § Senate, 1 (1852), 3.

${ }^{304}$ Secretary of the Navy, Report of the Secretary of the Navy.

${ }^{305}$ Secretary of War, "Fortifications at Fort Point and Alcatrazas Island," Pub. L. No. 8224, § House of Representatives, 1 (1854).

306 "City Slip Sale," December 26, 1853, Carton 5, Folder 5 Land: San Francisco, Bancroft Reference Notes for California, [ca. 1870-1890], Bancroft Library, University of California, Berkeley, California. 307 "City Slip Sale."

308 “A Quarter of a Century," September 27, 1875, Carton 18, Folder 1, San Francisco, Bancroft Reference Notes for California, [ca. 1870-1890], Bancroft Library, University of California, Berkeley, California.

${ }^{309}$ Bayard Taylor, "San Francisco Past and Present: The Changes of Twenty Years, Bayard Taylor's Third Visit," July 20, 1870, Carton 18, Folder 1, San Francisco, Bancroft Reference Notes for California, [ca. 1870-1890], Bancroft Library, University of California, Berkeley, California. 
first visited the city in 1847 documented the many streets that used to be covered in Bay that had since become part of the city. ${ }^{310}$ However, as the city continued to grow, the modification of the coastline began conflicting with other uses of the environment and setting.

By 1855, the growing waterfront eclipsed and filled Yerba Buena Cove, previously the best anchorage in the area. ${ }^{311}$ In 1863, San Francisco established the Board of State Harbor Commissioners, not to control the growth of the city, but to maintain, regulate and encourage the fill and development of the waterfront. The Board of State Harbor Commissioners was a three-member group with one member elected by the California State Senate, the second member elected by the California Assembly, and the third member elected by the City and County of San Francisco. These three commissioners were responsible for maintaining the seawalls, wharves, piers, and other structures along the San Francisco waterfront in good repair, undertaking dredging activities, and enabling the continuation trade and commerce in the harbor through other means, including the collection of rent and tolls and the construction of additional structures. ${ }^{312}$ One of the first tasks of the commissioners was the completion of the seawall around the northeastern portion of the city. Construction on the seawall started in 1859 with the goal of holding existing fill in place; however, early portions of the wall were piecemeal. ${ }^{313}$ By 1877 , a continuous

310 “There Used to Be In...," 1878, Carton 16, Folder 11 San Francisco, Bancroft Reference Notes for California, [ca. 1870-1890], Bancroft Library, University of California, Berkeley, California.

${ }^{311}$ Kemble, San Francisco Bay: A Pictorial Maritime History.

${ }^{312}$ Gerald Robert Dow, "Bay Fill in San Francisco: A History of Change" (San Francisco State University, 1973), San Francisco Maritime Research Library (William W. Helbush Papers, Folder 1).

${ }^{313}$ Charles Hall Page \& Associates, Inc., "Survey of Cultural Resources Piers 14-22 1/2 The Agricultural Building \& The Fire Boat House, The Port of San Francisco" (San Francisco, California, November 14, 1977), San Francisco Maritime Research Library. 
structure was completed which the Board of Commissioners would subsequently extend and adjust. ${ }^{314}$

San Franciscans constructed their coastal environment to support various priorities, including a military presence, trade along the waterfront, fishing infrastructure, and expansion of the modest land area of the peninsula. At the same time, new American arrivals to San Francisco also modified the biota of the area to please east coast palates. ${ }^{315}$ The native oysters of California, previously an important food source for the Miwok and Ohlone, were small by outside standards. ${ }^{316}$ They were first replaced with oysters from Washington state, and later, as railroads were built, with eastern oysters. ${ }^{317}$ Seed was shipped to California and planted to grow the larger oysters, more familiar to eastern consumers. Overtime, various parties introduced 21 species to the bay, fourteen of which persist and seven of which are important commercial or sport species in the area. ${ }^{318}$

As San Franciscans negotiated with the environment to perpetuate preferred species, the Army Corps of Engineers removed some of the navigational hazards that caused early surveyors to report unfavorably on the Bay. The Corps made careful study of each of the rock formations, justifying the removal by the relative danger and benefit. A "General Account of Progress," in the city, cites the removal of Blossom Rock in 1870 as a symbol of the progress of the city, both because the explosion brought "the end of the most dangerous obstruction to commerce in the bay of San

\footnotetext{
${ }^{314}$ Dow, "Bay Fill in San Francisco: A History of Change."

315 Jerry C. Towle, "Authored Ecosystems: Livingston Stone and the Transformation of California Fisheries," Environmental History 5, no. 1 (January 2000): 54-74; Matthew Morse Booker, "Oyster Growers and Oyster Pirates in San Francisco Bay," Pacific Historical Review 75, no. 1 (2006): 63-88. ${ }^{316}$ Kemble, San Francisco Bay: A Pictoral Maritime History.

${ }^{317}$ Fred S. Conte, "California Oyster Culture" (University of California, Davis Department of Animal Science, 1996), http://aqua.ucdavis.edu/DatabaseRoot/pdf/ASAQ-A07.PDF.

318 Towle, "Authored Ecosystems: Livingston Stone and the Transformation of California Fisheries."
} 
Francisco," and because the innovative method used to remove the rock was invented by a San Franciscan. ${ }^{319}$ In addition to Blossom Rock, the Corps removed Shag, Rincon Reef, and Arch Rocks to improve navigational safety and ease in the Bay. During the first decade of the $20^{\text {th }}$ century, the focus on navigation and commerce in the area continued. Congress authorized the construction of multiple lighthouses on rock outcroppings around the Bay. ${ }^{320}$ When the Corps determined certain nearshore rocks to be too dangerous to move, they instead recommended the extension of the pier head line in the city to include those rocks so they could instead be removed as navigational hazards by the extension of piers. ${ }^{321}$ By adding land, navigational aids, and species, and removing navigational hazards, marshes, and sandy hills from the peninsula, residents along the northern coast of the San Francisco peninsula established a pattern of local environmental interaction based on changing and altering the setting to suit commercial and military needs.

\section{Building a City Befitting of an American Empire}

As the Army Corps focused on improving the navigational setting of San Francisco Bay and the U.S. military built at Mare Island in the Northeastern portion of the bay, as well as Alcatraz and Angel Islands, and the land to both the north and south

\footnotetext{
319 “General Account of Progress Section 195 1870,” 1870, Carton 18, Folder 1, San Francisco, Bancroft Reference Notes for California, [ca. 1870-1890], Bancroft Library, University of California, Berkeley, California.

${ }^{320}$ Coombs, "Light and Fog-Signal Station in San Francisco Bay,” Pub. L. No. 734, § Committee on Interstate and Foreign Commerce, 1 (1902); Mallory, "Fog Signal at Quarry Point, California," Pub. L. No. 801, § Committee on Commerce, 1 (1904); Perkins, "Light-House, Etc. Red Rock, San Francisco Bay, California," Pub. L. No. 243, § Committee on Commerce, 1 (1906); Frye, “Additional Aids to Navigation in Light-House Establishment, Etc.,” Pub. L. No. 6512, § Committee on Commerce, 1 (1907).

${ }^{321}$ Secretary of War, "Survey of Shag Rocks and Other Rocks, San Francisco Harbor, California," Pub. L. No. 105, § Committee on Rivers and Harbors, 1 (1897).
} 
of the Golden Gate Strait, San Francisco residents and city boosters too worked to improve the city. However, their designs focused on constructing a modern and visually pleasing setting that would attract commerce and impress American and international audiences. When the 1906 earthquake struck San Francisco, residents rebuilt the area and less than 10 years later, hosted an international exposition to introduce America's Pacific gateway to the world. As San Franciscans added recreational spaces to the city and when plans for the Panama-Pacific Exposition required additional land, earlier and established patterns of environmental development continued, with residents building into the bay to create space for additional uses. The designed environment of the city as well as the fill into the Bay created contrast between the city and the wilderness of the American west, which Congress encouraged Americans to view on their way to San Francisco.

In 1902, prominent citizens of San Francisco, led by former San Francisco mayor, socialite and anti-Japanese campaigner James D. Phelan, formed the Association for the Improvement and Adornment of San Francisco and shortly hired architect Daniel Hudson Burnham to develop a plan for the development of the city. ${ }^{322}$ Burnham, a member of the team of architects that designed a plan for Washington D.C. in 1901, recommended the preservation of Black Point Cove for yachting and natural beauty. ${ }^{323}$ Black Point, the outcropping of land immediately east of the Presidio had a history of recreational use, with small beach houses built there from the

\footnotetext{
${ }^{322}$ Mel Scott, The San Francisco Bay Area: A Metropolis in Perspective, 2nd ed. (Berkeley, California: University of California Press, 1985), 99.

${ }^{323}$ Scott, 106.
} 
1860s onward. ${ }^{324}$ These early recreational uses of the area had to compete with the military uses as military piers were built in that location starting in 1863 and maintained and improved following winter storm damages in 1870, 1889, and 1912. The bathhouses at Black Point fell out of use as spaces like Crystal, Lurline, and Sutro Baths opened in 1890, 1894, and 1896, respectively. Although this recommendation supported the political stance of the Association for Improvement and Adornment of San Francisco against industrial rivals who wished to further fill develop the Black Point Cove area for industry, other local organizations including the Dolphin Club and their offshoot, the Aquatic Park Improvement Association, supported this vision and lobbied for recreational space in Black Point Cove.

The 1906 earthquake that rattled and burned San Francisco permanently altered the character of the northeastern waterfront. Piers burned to the waterline. And after crews extinguished fires sparked by the earthquake, city officials had the opportunity to rebuild the city along the lines of Burnham's plan. ${ }^{325}$ Instead, under the leadership of pro-industry Mayor Eugene Schmitz, the city dumped rubble into the cove west of Black Point and other areas along the northern shore, effectively contributing to two projects at once. ${ }^{326}$ Fill in Black Point Cove continued yearly through 1913, when workers placed rubble cleared from the railroad tunnel under Fort Mason in the cove. In 1908, the Engineers of the Federated Harbor Improvement Associations published a comprehensive plan of their vision for the development of the San Francisco waterfront. This plan reiterated the established idea that San

\footnotetext{
${ }^{324}$ James Delgado, “Pioneers, Politics, Progress, and Planning: The Story of San Francisco's Aquatic Park" (Golden Gate National Recreation Area, January 1981), 38.

325 Scott, The San Francisco Bay Area: A Metropolis in Perspective, 107-8.

${ }^{326}$ Delgado, "Pioneers, Politics, Progress, and Planning: The Story of San Francisco's Aquatic Park."
} 
Francisco had a good natural harbor, access to inland natural resources, and access to Asia arguing that the only limits on business development in San Francisco were port facilities. ${ }^{327}$ They recommend asking the Secretary of War for permission to extend the bulkhead line 45 meters into the Bay, which would allow for an additional 8.5 kilometers of developed waterfront space. ${ }^{328}$ In the same report, the Engineers of the Federated Harbor Improvements Association recommend concrete covered pilings to prevent damage from marine boring organisms and getting the pilings to a depth of at least 15 meters due to the soft mud of the San Francisco Bay. ${ }^{329}$

In 1912, San Francisco outcompeted New Orleans to host the 1915 Panama Pacific International Exposition (PPIE). With the opening of the Panama Canal, Congressional supporters of San Francisco's bid wanted to capitalize on the city's Pacific trade connections. ${ }^{330}$ Since the 1850 s, Congress encouraged the development of San Francisco as a hub of American trade with China and East Asia, financing lighthouses, customshouses, and fog signals to improve navigation in the area and repeatedly extending harbor lines to enable the construction of piers and warehouses on the city's eastern waterfront. The citizens of San Francisco welcomed the event,

\footnotetext{
${ }^{327}$ Luther Wagoner and W.H. Heuer, San Francisco Harbor: Its Commerce and Docks, with a Complete Plan for Development (Federated Harbor Improvement Associations, 1908), 4-9.

${ }^{328}$ Wagoner and Heuer, 25-26.

${ }^{329}$ Wagoner and Heuer, 36-41.

${ }^{330}$ While this was a justification for the decision, the bulk of the recorded discussion in Congress centered on the fact that the residents of San Francisco had raised more than twice as much money to be put towards the exposition than had the residents of New Orleans. While some members of Congress were concerned with access for citizens of the United States, arguing that major population centers were much closer to New Orleans than they were to San Francisco, others argued that past expositions weren't that well attended by people from these population centers anyways and that an exposition in San Francisco would be a great reason for Americans to visit the Pacific Coast where they could learn about the "almost inexhaustible" resources of the American west. Fassett, "Panama-Pacific International Exposition,” Pub. L. No. 1608, § Committee on Foreign Affairs, 1 (1910); Jones, "Panama-Pacific International Exposition," Pub. L. No. 1133, § Committee on Industrial Expositions, 1 (1911); Kahn, "Panama-Pacific International Exposition Co.," Pub. L. No. 237, § Committee on Military Affairs, 1 (1912).
} 
raising an initial $\$ 5,000,000$ to host the event, and eventually committing a total of $\$ 17,500,000$ towards construction and hosting. ${ }^{331}$ PPIE provided an opportunity to emphasize the power and vigor of the American nation, which had created an imperial city in the stark western wilderness. ${ }^{332}$ Surrounded by landscapes like Yosemite, San Francisco also emphasized American might and technological prowess in that the urban metropolis presented to visitors arose from the rubble of the 1906 earthquake less than a decade prior, and originally, from a dusty Mexican pueblo less than 50 years prior. ${ }^{333}$ Much like the constructed spaces the imperial metropolis PPIE would showcase, San Franciscans set about building land for the exposition.

Within San Francisco, the Harbor View area won the contract to host PPIE. The Exposition Commission borrowed most of the acreage from Fort Mason and the Presidio. However, the Committee also leased and purchased less than one square kilometers of private land from the Fulton Engineering and Shipbuilding Company and others. ${ }^{334}$ Land creation in the Harbor View district of San Francisco, at the north end of the city near the Presidio and Fort Mason started for industrial purposes in the late $19^{\text {th }}$ century. The area was filled with earth and rocks acquired by leveling hills in North Beach. ${ }^{335}$ In order to construct a large flat space to host the various temporary structures and exhibits associated with PPIE, the committee razed old homes and buildings, filled the tidelands up to the bulkhead line, constructed a new seawall along

\footnotetext{
${ }^{331}$ Sarah J. Moore, Empire on Display: San Francisco's Panama-Pacific International Exposition of 1915 (Norman, Oklahoma: University of Oklahoma Press, 2013), 90.

${ }_{332}$ Moore, 4.

${ }^{333}$ Judd Kahn, Imperial San Francisco: Politics and Planning in an American City, 1897-1906 (Lincoln, Nebraska: University of Nebraska Press, 1979).

${ }^{334}$ Dow, "Bay Fill in San Francisco: A History of Change."

${ }^{335}$ Dow.
} 
the shoreline to prevent the erosion of the fill, and filled marsh at the Presidio. ${ }^{336}$ The project eventually filled in 300 square meters that had been submerged in up to 3.5 meters of water. ${ }^{337}$

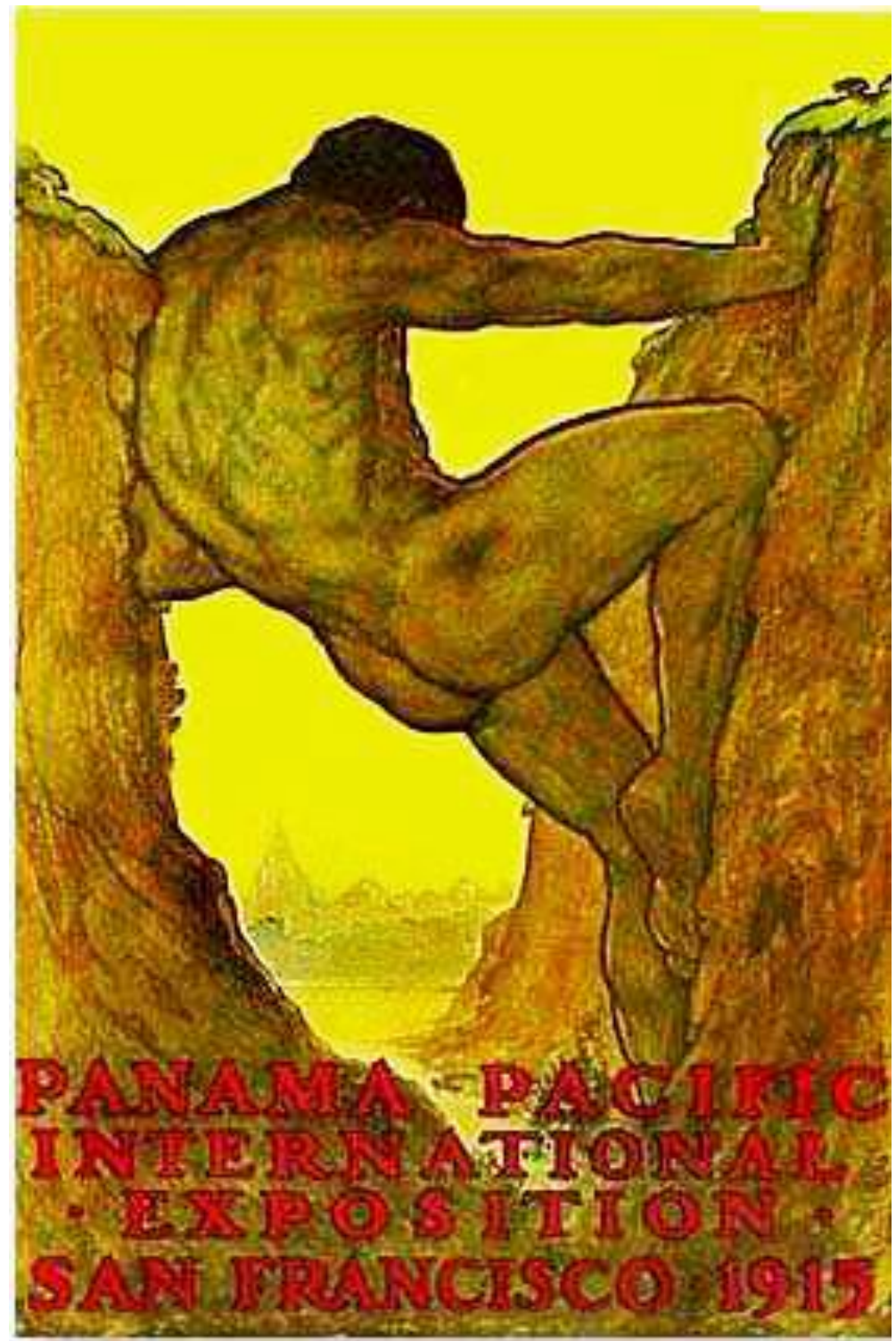

Figure 9. Panama-Pacific International Exposition poster symbolizing the rebuilding San Francisco after the 1906 earthquake. ${ }^{338}$

336 Dow.

${ }^{337}$ Dow.

${ }^{338}$ National Park Service, "Panama-Pacific International Exposition, 1915: The World Meets in San Francisco" (National Park Service, June 2015), https://www.nps.gov/goga/learn/historyculture/upload/PPIE-Brochure-FINAL-for-Web.pdf. 
Although the goal of PPIE was to show the might, industrial development, and technological prowess of the early $20^{\text {th }}$ century United States in their ability to build a world-class city out of the wild Pacific coast, the perspectives of managers for this early recreational use of the northern portion of San Francisco took the same approach as early American ventures: construct the space. The PPIE Commission leased additional land from the Army, under the conditions that the Army retain the improvements made to these spaces after the exposition. When PPIE closed in 1916, the Army took over the improved water pipes, short distance rail transport and tunnel under Fort Mason, and certain temporary buildings at the Presidio. ${ }^{339}$ The Army also used the newly filled Crissy Field as an airfield. Today, the only structure remaining from the exposition is the Palace of Arts.

While PPIE had brought commercial connections, visitors, and international attention to the city, after World War I, San Francisco residents resumed their fight against national priorities along the shoreline and lobbied for more recreational space. This lobby of San Francisco boosters, yachtsman, and other locals argued that the state legislature should "make San Francisco a safe place to swim, row and fish." ${ }^{340}$ In 1917, the City of San Francisco approved the transfer of lands for recreational purposes. After a decade of lobbying, local voices for recreational space won; however, the construction were slow coming. In 1928, city officials asked Congress for permission to remove the existing government pier and built a new pier as part of

\footnotetext{
${ }^{339}$ Kahn, "Panama Pacific International Exposition Co.," Pub. L. No. 237, 1 (1912); Bristow, "Right of Way Across Fort Mason Military Reservation, California,” Pub. L. No. 887, 1 (1912).

340 Delgado, "Pioneers, Politics, Progress, and Planning: The Story of San Francisco’s Aquatic Park."
} 
Aquatic Park. ${ }^{341}$ The new pier area as planned also encroached on the grounds of Fort Mason, but the War Department did not object to this change. ${ }^{342}$ When the city got WPA money to work on Aquatic Park between 1936 and 1938, it became clear that the San Francisco Board of Supervisors wasn't reserving a space for recreation, but creating one. To create Aquatic Park, workers extended seaward Van Ness Avenue to meet the new pier, the seawall was extended and backfilled extensively, and the entire area was cobbled. ${ }^{343}$ After the space had been created, workers brought excavated sand from other construction sites in the city to create a beach. However, the borrowed sand did not stay put during storms and later the city installed breakwaters to keep the sand in place. Although the uses and goals for this area of the shoreline were changing, the ways of accomplishing them remain the same. As with the construction of Golden Gate Park, which started 50 years earlier, San Francisco would design, construct, and build a planned and intentional natural space. ${ }^{344}$ Between World Wars I and II, Congress granted permission to build both the Golden Gate and Bay Bridges as long as they did not interfere with navigation and naval anchorage in the Bay. ${ }^{345}$ The construction of these bridges led to another commemorative event of the growth and development of the San Francisco area in 1939, which was held on the newly built Treasure Island. ${ }^{346}$ Treasure Island was built in the Yerba Buena shoals, taking up approximately 3 square kilometers of formerly

\footnotetext{
${ }^{341}$ Wagner, "Recreation Pier at the Foot of Van Ness Avenue, San Francisco, California," Pub. L. No. 187, 1 (1928).

${ }^{342}$ Wagner.

${ }^{343}$ Delgado, "Pioneers, Politics, Progress, and Planning: The Story of San Francisco's Aquatic Park."

${ }^{344}$ Terence Young, Building San Francisco's Parks, 1850-1930, Creating the North American Landscape (Baltimore, Maryland: The Johns Hopkins University Press, 2004).

${ }^{345}$ Johnson, "Bridge Across San Francisco Bay," Pub. L. No. 33, § Committee on Commerce, 1 (1929). ${ }^{346}$ McReynolds, "San Francisco Bay Exposition in 1939, at San Francisco, California," Pub. L. No. 2687, § Committee on Foreign Affairs, 1 (1936).
} 
shallow sand and mud off the northern portion of Yerba Buena Island. ${ }^{347}$ The Marine Development Bureau of the Army Corps of Engineers reported on the San Francisco Bay in 1933, 1962 and 1990. At the time the 1933 report was written, the Army Corps was in the process of deepening the bar through the channel from 9.5 to 14 meters. ${ }^{348}$ Until this project started, the report notes that the only Federal improvements to the Bay have been the removal of various rocks. ${ }^{349}$ While this statement emphasizes the state control over the pier, it obscures the role of the federal government in the creation of the San Francisco shoreline through military construction, other navigational work like lighthouses, and commercial projects like PPIE. Much like PPIE represented both federal and certain local interests, federal navigation improvements in the area aided the work of the harbor commission in updating and replacing weathering piers and deepening the water alongside these berths. ${ }^{350}$ Since San Francisco was the second busiest salt water approach in the country, the Army Corps of Engineers readily supported the area with dredging and navigational improvements, benefitting both local interests and national visions of San Francisco. ${ }^{351}$

The Army Corps saw dredging and fill in the San Francisco Bay as improvements for navigation, commerce and necessary changes for the maintenance of good port conditions rather than an environmental alteration. By 1960, the surface

\footnotetext{
${ }^{347}$ Charles H. Lee and Michael Praszker, "Bay Mud Developments and Related Structural Foundations," Geologic and Engineering Aspects of San Francisco Bay Fill (San Francisco, California: California Division of Mines and Geology, 1969).

${ }^{348}$ U.S. Board of Engineers for Rivers and Harbors, The Ports of San Francisco, Oakland, Berkeley, Richmond, Upper San Francisco Bay, Santa Cruz, and Monterey California (Washington, D.C.: United States Government Printing Office, 1933), 1.

${ }^{349}$ U.S. Board of Engineers for Rivers and Harbors, 12.

${ }^{350}$ Ibid., 51.

${ }^{351}$ Ibid.
} 
area of the Bay had decreased 650 square kilometers since Americans claimed the area in $1846 .{ }^{352}$ More of the San Francisco Bay was filled between 1939 and 1969 than during any previous period. ${ }^{353}$ However, the Marine Development Bureau Report on the Bay in 1962, updated from the 1933 report, reflects very few changes. ${ }^{354}$ In 1959 , using data from predicted population increases in the Bay Area, the Army Corps of Engineers put forth a plan to accommodate the growing population that involved filling 840 square kilometer of the remaining 1260 square kilometers of tidal wetlands in the Bay Area. ${ }^{355}$ In a report by the California Division of Mines and Geology published in 1969, Geologist Harold Goldman calculated that the water in the entire Bay could be replaced with approximately 10 billion cubic yards of fill, suggesting that rock formations around the Bay rather than quarried stone would provide a more economical source for the fill material. ${ }^{356}$

\section{Recreation and the Need for Urban Green and Blue Spaces}

While the Army Corps of Engineers proposed extensive fill of the Bay for commercial development, during the 1960s, local, public opposition in the area again protested the industrial dominance of the entire waterfront. When residents rejected additional fill to create more land in the Bay, this demand represented a new interaction between San Franciscans and the Bay, and a shift in the perception of the

\footnotetext{
352 Okamoto and Wong, Natural History of San Francisco Bay, 152.

${ }^{353}$ Lee and Praszker, "Bay Mud Developments and Related Structural Foundations."

${ }^{354}$ The Board of Engineers for Rivers and Harbors, The Ports of San Francisco, Redwood City, California (Washington, D.C.: United States Government Printing Office, 1962).

${ }^{355}$ Philip J. Dreyfus, Our Better Nature: Environment and the Making of San Francisco (Norman, Oklahoma: University of Oklahoma Press, 2008), 164.

${ }^{356}$ Harold B. Goldman, "Salt, Sand and Shells: Mineral Resources of the San Francisco Bay," Geologic and Engineering Aspects of San Francisco Bay Fill (San Francisco, California: California Division of Mines and Geology, 1969), 35.
} 
local environment. However, while San Franciscans had elected not to build into the Bay for an additional use, managers of the North Beach and Marina districts continued to insert an element of design in their management of the area. With the creation of Golden Gate National Recreation Area and the inclusion of a portion of the northeastern waterfront in the park, preservation became another one amongst the overlapping uses along the waterfront. As managers worked to incorporate park goals into the area, federal managers incorporated the preservation and tourism needs into the design of infrastructure and construction along the waterfront.

In 1965, California State Senate Bill 309 formed the San Francisco Bay Conservation and Development Commission (BCDC) in response to public concern about the loss of bay waters and shoreline to development. BCDC prepared a comprehensive plan for the conservation of the San Francisco Bay and the development of the shoreline. The BCDC developed to defend the public interest in the health of the Bay and to oversee a more comprehensive plan for the shoreline, rather than planning in discrete sections, an idea codified in the Coastal Zone Management Act seven years later. However, the establishment of the BCDC did not transform the uses and priorities of the shoreline overnight. Initially, BCDC could only reject fill permits if they extended more than 30 meters into the water or if they did not provide enough public access. ${ }^{357}$ In 1972, the State of California updated the regulatory charge of $\mathrm{BCDC}$, allowing the group to reject projects where proposed fill is not for a water oriented use or when public benefits do not exceed public

357 “Protecting America's Estuaries: The San Francisco Bay and Delta,” Pub. L. No. 1433, § Committee on Government Operations, 1 (1970). 
detriment. ${ }^{358}$ Rather than halting development along the shoreline, this regulation added recreation-oriented use to the list of shoreline priorities.

Other projects that officially recognized the expansion of recreational uses similarly worked to construct spaces. In the years following the Civil War, residents of San Francisco started requesting urban green space. The city built Golden Gate Park in the outside lands, on the Pacific shore of the city, an area previously rejected by the Yelamu Tribe, as well as early Spanish settlers because of its exposure to wind and fog. ${ }^{359}$ One-hundred years later, discussions about a national park. As the Department of the Interior began outlining Golden Gate National Recreation Area, ranchers and resort managers in the area alike argued that their uses of the space should continue as their goals were consistent with those of the park. In 1971, the draft Environmental Impact Statement outlined that the proposed Golden Gate National Recreation Area would "protect and preserve in public ownership hose existing large areas of relatively natural landscapes and restore in selected previously urbanized areas a more natural state." 360 The same statement argues that Golden Gate National Recreation Area represents “the only positive direction to solve today's problem of environmental deterioration." ${ }^{361}$ As the park was established and assembled in multiple units including wilderness units north of San Francisco, the San Francisco Maritime Museum unit, and eventually, the Presidio and Fort Mason, after the military vacated.

\footnotetext{
${ }^{358}$ Hart, “San Francisco Bay National Wildlife Refuge,” Pub. L. No. 859, § Committee on Commerce, 1 (1972).

${ }^{359}$ Dreyfus, Our Better Nature: Environment and the Making of San Francisco, 86.

360 "Proposed Golden Gate National Recreation Area: Draft Environmental Impact Statement," August 6, 1971, 1, Record Group 48 Records of the Office of the Secretary of the Interior, Central Classified Files, 1969-1972, Box 182, National Archives, College Park, Maryland.

361 "Proposed Golden Gate National Recreation Area: Draft Environmental Impact Statement," 3.
} 
As the area along the northern portion of San Francisco became partially park space, meant to attract tourists, the means of achieving this new goal was the consistent with the past methods of creating San Francisco. The Army Corps proposed a plan to construct additional fishing berths and infrastructure to revive the traditional use of the area for the sake of tourism. In an economic addendum to the report, the Corps found this project to be financially justifiable with the total annual benefit far exceeding the annual cost through the previous study, or almost doubling the annual benefit by the way they made calculations. ${ }^{362}$ The Corps argues that better facilities in San Francisco would "attract fishing boats from adjacent crowded harbors, such as Sausalito, Oakland and Alameda, thereby increasing related business and employment and preserving the complex network of historic, cultural and economic relationships in the area." 363 The Corps further identifies that fishing captains have left this port because the vessels are being damaged due to wave action. A 1973 survey found that $60 \%$ of the fishermen in San Francisco still live within 10 blocks of the wharf thus this improvement would be helpful to the local economy. And while this change is focused on infrastructure for the fishermen, the report states, "with improved conditions for the local cultural attraction, commercial fishermen at work, tourist activity would be enhanced." 364 Construction to protect the fishing vessels would also protect the historic fleet at Hyde Street Pier. ${ }^{365}$ While Pier 45 on San Francisco’s waterfront hosts

\footnotetext{
362 Assistant Secretary of the Army (Civil Works), "San Francisco Harbor, California: Fisherman's Wharf Area," Pub. L. No. 13530, § Committee on Public Works and Transportation, 1 (1983). 363 Army Corps of Engineers, San Francisco Division, "Breakwater Study for Light Draft Navigation" (Army Corps of Engineers, 1975), 11, San Francisco Maritime Research Library.

364 U.S. Army Corps of Engineers, "Environmental Statement, Fisherman's Wharf, San Francisco Harbor, California” (San Francisco, California, December 1977), 21, San Francisco Maritime Research Library.

${ }^{365}$ U.S. Army Corps of Engineers, “Environmental Statement, Fisherman's Wharf, San Francisco Harbor, California."
} 
commercial fishermen and fish processing, the Army Corps of Engineers chose to address the tourist industry by constructing a space for a different industry.

As the Army Corps was building fishing infrastructure for tourism, managers of Golden Gate National Recreation Area were addressing small scale fishing from the piers in the park. Despite the historic use of the area for fishing and the desire to encourage tourism with the industrial fishing seen from fishermen's wharf, recreational, subsistence, and small-scale fishing of approximately 40,000 fishermen annually, from the pier conflicted with the special events hosted by the park. ${ }^{366}$ Later, when conservation measures for Dungeness crab were introduced, people fishing on the pier realized NPS staff were not able to regulate their activities and this became a management issue. The fishing occurring in the area was changing in form; however, despite trying to preserve the historic fishing in the area, and manager's concerns that commercial fishing is no longer visible on the landscape, the ongoing, local shore fishing was not consistent with the Army Corps and NPS vision of the space.

In 1987, NPS responsibility for the historic fleet changed from preserving the fleet in "seaworthy condition" to protecting the vessels from "prevailing winds, winter storms, tides, and wave action." 367 The historic fleet at SAFR are large, outdoor

\footnotetext{
366 “Annual Report of the Golden Gate National Recreation Area, 1983," 1984, Record Group 79 Records of the National Park Service, Superintendent's Annual Narrative Reports, 1980-2001, Box 25, National Archives, College Park, Maryland; Similarly, while the National Wildlife Refuge established in the Bay addressed the concerns of rising environmental groups about managing the environment as a whole, the initial legislation for the National Wildlife Refuge emphasized the human value of the space for recreation and education. The legislation that established the wildlife refuge focused on mud flats as feeding areas for wildlife, but not for humans. In selecting lands for the wildlife refuge, they focused on areas that are "relatively unspoiled and not marred by developments," and worked with the Leslie Salt Company to acquire former salt ponds, in addition to other areas. However, in the same document, wrote allowances for boat tours, interpretation, group train, and some hunting blinds. For more information, see Jones, "Enlargement of the San Francisco Bay National Wildlife Refuge," Pub. L. No. 971, § Committee on Merchant Marine and Fisheries, 1 (1988).

${ }^{367}$ Udall, "National Maritime Museum Act of 1987," Pub. L. No. 13800, § Committee on Interior and Insular Affairs, 1 (1987).
} 
museum pieces that are important in themselves and as part of the landscape of the park and city. As the waterfront of North Beach transitioned from a working space to a recreational space, the vessels would similarly transition from working vessels to floating museum pieces. Similarly, structures such as the Haslett Warehouse, which meets National Register criteria for local, not national, significance, but was welllocated, available, and appropriate for a museum space became a part of national park. ${ }^{368}$ In an urban setting of overlapping uses, national NPS priorities worked alongside local priorities to negotiate a space. The other major space owned by the City of San Francisco, but managed by NPS include the Hyde Street Pier. Built as a Ferry Pier in 1922 and rehabilitated in 1963, the Hyde Street Pier is now the centerpiece of San Francisco Maritime National Historical Park (SAFR), rented from the city, which holds the historic fleet.

In 1988, the Maritime Museum Unit and the historic fleet that were formerly part of Golden Gate National Recreation Area became an independent park unit, San Francisco Maritime National Historic Park (SAFR). While Golden Gate National Recreation Area was founded to provide urban green space, the Maritime Museum unit was originally a research space. As an independent unit, SAFR manages both part of the recreational history of the city and the space through the Maritime Museum building, as well as an extensive archival collection, as well as part of the industrial, fishing, and sailing history of the bay with the historic fleet, moored at Hyde Street Pier. The recreational history on the San Francisco waterfront is a local history,

\footnotetext{
${ }^{368}$ National Park Service, "Haslett Warehouse, National Maritime Museum, Golden Gate National Recreation Area," September 11, 1987, Record Group 79, Division of Interpretive Planning, Records of Public Input Documenting Interpretive Planning Activities, 1955-1999, Box 227, National Archives, College Park, Maryland.
} 
lobbied and built by San Franciscans, while a federal vision of a Pacific Industrial capital led to Army Corps construction and supported the industrial history of the San Francisco waterfront. However, both local and national uses of the San Francisco waterfront have rearranged nature, confusing the original lines of the bay to gain and retain space for their priorities.

In 1989, the Loma Prieta earthquake registered as a 6.9 on the Richter scale in San Francisco, killing 67 people and causing six-billion dollars' worth of damage. ${ }^{369}$ At SAFR, the earthquake damaged Hyde Street Pier, splitting and cracking timber piles. ${ }^{370}$ In 1990, an architectural survey of the pier in expressed concern about the impacts of currents, tides, winds, load, and tsunamis on the pier structure. ${ }^{371}$ The Army Corps prediction for the longevity of timber piles in the harsh marine environment is 25-45 years. ${ }^{372}$ The Environmental Assessment of the Amphitheater Structure suggested that environmental deterioration due to both the age of the structure and the damaging salt environment had caused the deterioration, and in the plans for renewal, preferred to return the area to the look it had in the 1938 plan. ${ }^{373}$ The fog and salt environment, an early concern for Spanish settlers in the area, again became a concern as national priorities grew to include the preservation of structures in the space in addition to the industrial use of the waterfront.

\footnotetext{
${ }^{369}$ Peter L. Ward and Robert A. Page, “The Loma Prieta Earthquake of October 17, 1989” (U.S. Geological Survey, January 1980), 7, https://pubs.usgs.gov/unnumbered/70039527/report.pdf.

${ }^{370}$ Moffatt \& Nichol, Engineers and Wallace Roberts Todd, "Hyde Street Pier Architectural and Engineering Study" (San Francisco, California: National Park Service, March 1990), San Francisco Maritime Research Library.

${ }^{371}$ Moffatt \& Nichol, Engineers and Todd.

372 Moffatt \& Nichol, Engineers and Todd.

${ }^{373}$ National Park Service, "Environmental Assessment: Rehabilitate Failing Amphitheater Structure in Aquatic Park National Historic Landmark District" (San Francisco, California: National Park Service, April 2006), 24, San Francisco Maritime Research Library.
} 


\section{Climate Change, Sea Level Rise, and a New Direction for Land Reclamation}

On the national stage, as recreation grew in importance during the $20^{\text {th }}$ century, coastal fringes, once dominated by military fortresses and active port facilities have given way to recreational spaces. During this transition, national priorities in the area have expanded to include an NPS vision for the space. As NPS managers begin to address the impacts of climate change on the cultural landscapes of SAFR, the ongoing negotiation between different priorities for space along the waterfront, as well as the ongoing negotiation with the foggy bay environment will continue to influence adaptation and development in the area. And the rising sea levels in the bay will continue to obscure the natural and built boundaries in the area. The cultural heritage of the San Francisco Bay Area is a legacy of both intentional and unintentional environmental change. Obscured by the fog, rearranged by the wind, altered by mine runoff, and constructed to show American industrial might, San Francisco is an engineered city. Environmental manipulation created the city and the sum of those environmental changes now threaten to inundate the tangible remains of the past housed at SAFR.

At SAFR, NPS priorities include maintaining and protecting the vessels, structures and collections in their care along the shoreline, and the accompanying recreational and research uses of these spaces. In the Bay Area, NPS managers anticipate changes to sea surface temperature, sea level, species distribution patterns, wildfire ranges, ocean acidity, ocean current patterns, and potentially other features of the system. ${ }^{374}$ Each of these potential changes could challenge the ability of managers

\footnotetext{
${ }^{374}$ Patrick Gonzalez, "Climate Change in the National Parks of the San Francisco Bay Area, California, USA," July 11, 2016.
} 
to address current priorities of preserving the cultural heritage and natural setting in parks. As such, federal managers priorities in this area now focus on maintaining existing temperate, sea level, and shoreline boundaries. SAFR became a Climate Friendly Park in 2009, with the goal of reducing park emissions and serving as a teaching platform to encourage visitors to reduce their contribution to climate change. ${ }^{375}$ In addition to teaching, NPS managers are working to inventory historic and natural features within parks, determine the likelihood of climate change damages to each feature, and determine whether these features should be a focus of climate change efforts, or whether these features should be allowed to weather normally. ${ }^{376}$ While previous federal priorities along the waterfront of San Francisco required engineering the setting, NPS priorities require a preservation of the setting.

However, SAFR is in a complex urban setting of overlapping uses. In addition to an ongoing heritage of building and engineering the shoreline in the area, the overlapping uses contribute to the dynamic boundaries in San Francisco. SAFR is reliant on the seawall system of the city of San Francisco in addition to two city piers. To work towards the preservation of the heritage priorities the site now represents, federal managers will work with city, state, and local groups to determine how to engineer the space. The options provided by NPS for management including allowing a built structure to weather, engineering a change to reduce the weathering impact on the structure, relocating the structure, or documenting the structure before it erodes have each been employed before along the San Francisco waterfront. While the federal

\footnotetext{
${ }^{375}$ National Park Service, "San Francisco Maritime National Historical Park Action Plan" (National Park Service, October 27, 2009).

${ }^{376}$ Gonzalez, "Climate Change in the National Parks of the San Francisco Bay Area, California, USA."
} 
priorities in the area have changed, the mechanisms to accomplish these priorities remain consistent with past management actions.

The location of SAFR is not a commemorative space, memorialized for an event that happened there. The space is a representative one that met $20^{\text {th }}$ century recreation requirements and fit within the complex urban system of the city. The historic fleet is a floating museum collection. While climate change could increase the amount of maintenance the ships require due to higher air and water temperatures, increased destructive biological growth, and storm damages from contact with the pier, the value of the historic fleet is not dependent on one location. However, Aquatic Park and the Maritime Museum building are important visual components of the San Francisco waterfront and are tied their location. The management options for these resources are very different. And managers' options in addressing the impacts of climate change on these resources will be tied to broader urban planning efforts for the San Francisco seawall and the Port of San Francisco's waterfront immediately bordering Aquatic Park to the south.

\section{Climate Change as a Shared Feature along San Francisco's Built Shoreline}

With the discovery of gold and the formal annexation of California by the United States in 1848, San Francisco developed overnight from a trading post to an urban port city. Whatever features San Francisco's physical environment lacked to become the Pacific representative of American trade and might, federal and city officials engineered, rearranged, or constructed. ${ }^{377}$ Continual fill into the Bay, the foggy conditions which obscured coastal boundaries and caused built structures to

${ }^{377}$ Dreyfus, Our Better Nature: Environment and the Making of San Francisco, 120. 
deteriorate, earthquakes, and fires each contributed to a local environment where building and rebuilding were the norm. The heritage of San Francisco is one of engineering, building, and creating in the face of coupled human-environmental change. And this pattern of environmental interactions from the early American development in the area left not only a physical legacy in the city, but contributed to the patterns of continual building and development of the northeastern shoreline of the city for the following century.

The North Beach and Marina districts, both partially constructed on filled land, have strong connections with fishing, shipping, and recreational uses of the Bay waters. However, the design of the city as a whole was meant to set it apart from the wilderness of the American west. The urban landscape that encouraged early managers and San Franciscans to build more land as they needed it, rearrange the Bay, and construct showcases of American development into the waterfront has only increased in complexity with the passage of time. Early construction into the Bay focused on military and commercial development; however, later recreational and exposition space were similarly built as needed into the waters of the Bay, first with parts of the Marina District for the Panama-Pacific International Exposition and later Treasure Island. Starting in the 1960s, residents of the city began to protest construction into the Bay, desiring space for shoreline access and water-based recreation. Along the limited urban shoreline, each additional shoreline use adds a layer of complexity to the area.

In the 1970s, the Corps suggested that the fishing infrastructure would contribute to tourism, and today, NPS manages piers that are owned by the City of San 
Francisco, commuter walkways, and tells the history of fishing along the waterfront, but upholds fishing bans on endangered species within the park area. NPS managers see climate change as a question of working with neighbors to improve and elevate the seawall or construct higher piers, continuing the local relationship with environment. However, climate change may challenge San Francisco to transition this trajectory of change to a discussion of unbuilding rather than building the coastline. 
CHAPTER 6: FROM RESOURCE- TO PROCESS-BASED MANAGEMENT:

LOCAL MANIFESTATIONS OF NATIONAL CULTURAL RESOURCE

MANAGEMENT PRIORITIES IN THREE COASTAL NATIONAL PARKS

\begin{abstract}
For the past 250 years, the United States, represented by the Army Corps of Engineers, state agencies, and more recently the National Park Service, have managed coastal fringes around the country. During this period, American uses, goals, and priorities in coastal spaces have changed. As coastal managers have integrated American priorities into the management of coastal spaces, these ideas have been recorded, preserved, and in some cases perpetuated through the legislation, policy, environmental manipulations, human expectations, and human uses of the environment. Within the last few decades, climate change has increased the frequency and intensity of coastal erosion, storm surge, sea level rise, and flooding along coastlines, threatening the natural resources and cultural resources managed by the U.S. National Park Service. Human responses to these changes are part of an ongoing process in these landscapes. Using a combination of document analysis and key informant interviews, I outline how national management priorities in coastal spaces have changed overtime. Then I focus on three national park sites selected for maximum variation and examine how the local environment, perceptions of regional and local managers, and local priorities have aligned or conflicted with broader national management trends in three coastal locations overtime. Using a framework developed from landscape studies in each of the three locations, I identify how managers have perceived change in the landscape overtime by assessing their management goals, the expectations of permanence, their rationale for generating environmental change, and their response to environmental change.
\end{abstract}

\title{
Introduction
}

Cultural resources are the tangible remains of how individuals and groups

perceived and used local environments overtime (Brumann 2015; Whitney 1996). The

goals of natural and cultural resource management have changed overtime as national

priorities, scientific understandings, historic preservation developments, and public

preferences have shifted (Hays 1980; Nash 1968). The fields of archaeology and

historical preservation developed alongside a growing fear that modernity would erase 
past objects and lifeways (Hosmer, Jr. 1981a). Today, cultural resources contribute to a valuable tourist and recreation economy, as well as academic research and cultural and aesthetic community values (Claesson 2011). Since its inception in 1916, the National Park Service has become the premiere cultural resource management agency in the country (NPS 2013; King 2000). As national values, disciplinary perspectives on cultural resource preservation and management, and most recently, climate change, have altered the way in which NPS manages cultural resources to meet research, planning, and stewardship goals.

Other disciplines have defined the shift in management priorities and objectives to include and harmonize with conflicting parts of overlapping systems as “integrated coastal management” and "ecosystem-based management.” In cultural resource management, efforts to look at broader patterns across human and natural systems include NPS cultural landscapes. NPS began using the phrase "cultural landscapes" in 1988 to describe designed spaces, ethnographic areas, and vernacular settings (Flint McClelland 1998). More recently, the National Oceanic and Atmospheric Administration's (NOAA) put forward a call for NOAA Marine Protected Areas to use a cultural landscapes approach in their recommendations for advancing cultural heritage within the Marine Protected Area System (Marine Protected Areas Federal Advisory Committee 2011). Distinct from cultural landscapes as defined by the National Park Service (NPS), this approach looks across natural, social, political, and ecosystem boundaries to identify the many contributing features to the landscape that are key for preservation and maintenance thereof (Marine Protected Areas Federal Advisory Committee 2011). 
As management changes, the way in which managers value and preserve the resources will also change. And these preservation decisions and priorities contribute to and affect the entire system moving forward. While the move to ecosystem-based management is present in the literature, the management of cultural resources within this broader transition is less well-documented. Cultural resources are part of broader landscapes and ecosystems (Tengberg et al. 2012). Climate change impacts vary by location (IPCC 2014). Cultural resources similarly vary by location, as these resources were originally built for local climate conditions or are innately connected with the local environment (Graham, Ashworth, and Tunbridge 2000). Management goals, managers' expectations of permanence, managers' rationale for creating change in the environment, and managers' responses to environmental change all indicate how managers perceive and interact with the environment, cultural resources, and change overtime (Casey 2018, in prep). This research addresses the question, how have changes in the management of cultural resources and park landscapes overtime affected the framing of risk relative to climate change?

\section{National Management Context}

Parks and coastal areas are part of a broader American context. For the young American government, commercial development was a priority and early policies encouraged individuals and businesses to manipulate the environment for development. The Rivers and Harbors Act of 1824 directed the Army Corps of Engineers to make rivers and harbors more accessible to encourage commercial development and trade. The Swamplands Act encouraged new landowners to fill 
wastelands to create productive areas. This focus on privatization for development started American environmental policy and represented a divergence from British policies. New policies put forth by the American government did not create de facto preservation by restraining exploitation. During this period, some of the sites that would later become cultural resources such as military installations, battlefields, and colonial archaeological sites were under the purview of federal managers. However, these resources were objects of industry, military, personal or other uses before they became places and objects of recreation, research, and appreciation.

Ideas of cultural resource conservation started in the early $20^{\text {th }}$ century. The Progressive politics and accompanying conservation movement of the early $20^{\text {th }}$ century, was rooted in the efficient use of resources and management of those resources by scientific expertise rather than political or legislative rational (Dorsey 1995; Hays 1999). In 1906, the Antiquities Act allowed the President to declare historic landmarks, structures, and objects on areas of federal land. In Preservation Comes of Age, Hosmer Jr. (1981a) traces the start of American historical preservation to the feeling post World War I that the United States was changing rapidly. Amidst the fear that technological development and modernity would make the lives of parents and grandparents unrecognizable to younger generations, museums memorializing the recent past began to open (Hosmer, Jr. 1981a). And historically significant battlefields, initially managed by the U.S. Army and U.S. Army Corps, transferred to the purview of the National Park Service.

The conservation of natural and cultural resources through parks with government oversight, that managed to maintain both "wild" America as well as the 
"past" America continued and during the Great Depression (Hosmer, Jr. 1981a). The Civilian Conservation Corps worked on various infrastructure improvements that created clean, open, and organized recreational spaces in the national parks. The Wildlife Coordination Act of 1934 strove to protect fish and game species favored by hunters. And the and the Historic Sites Act of 1935 empowered the Secretary of the Interior to "restore, reconstruct, rehabilitate, preserve and maintain historic or prehistoric sites" to inspire, benefit and educate the public. The National Park Service hired archaeologists, architects and other experts to conduct these surveys and with this expertise, eventually became the lead federal agency for preservation (Andrews 1999). By the 1950s, NPS began to work on the National Survey of Historic Buildings and Sites, the National Register of Historic Places and eventually the founding of the National Trust which would record and preserve historic structures (Hosmer, Jr. 1981b). This legislation focused on the uses of natural and historic spaces and sites for recreational and educational purposes.

In the 1950s, NPS policy was transformed by the Leopold Report which pushed for national parks to represent "vignettes of primitive America," by restoring the environment to a condition as defined by the perceived status of nature "when it was first visited by the white man (Leopold et al. 1963, 32)." Although the idea of restoring nature to the state it was in at the time of European contact has been discredited for failing to acknowledge Native American management, and wilderness as a culturally defined space (Cronon 1995), the idea of restoring nature to a specific standard has not disappeared from the management plans of NPS, but changed form. Congress enacted laws during the 1960s and early 1970s that represented the first legal 
protections both human and natural systems simultaneously. Although the National Environmental Policy Act (NEPA) targeted the protection of the environment, the act also aims to "preserve important historic, cultural and natural aspects of our national heritage." Three years prior to the enactment of NEPA, the National Historic Preservation Act of 1966 (NHPA) stated that historic properties are both irreplaceable and being lost with increased frequency. To combat this, NHPA took a multi-prong approach aimed at both increasing the number of historic buildings nominated by extra-governmental bodies, and better protecting designated structures through Section 106. Section 106 of the NHPA requires federal agencies to determine that their proposed courses of action will not harm or destroy archaeological or historical sites. These consistency determinations recognized that a growing American population was using the same spaces for different purposes.

Following the rash of legislation over these two decades, the 1980s and 1990s focused on efficiency-based reform, trying to integrate economic and environmental goals into one policy. In NPS, managers moved towards increasingly scientific approaches to management in the 1980s and 1990s, emphasizing monitoring programs, species and ecological restoration, and historic preservation measures. During this same period, global climate change, known by one of its many names, has become the next and dominant risk to the preservation of natural and cultural resources (Jarvis 2009). In the absence of an overarching federal act on climate change, the National Park Service and other agencies working to address climate change have integrated natural and cultural resources in their discussions, borrowing from EPA risk assessment procedures to format climate change actions. Over the past 
decade, NPS has published many important documents addressing climate change and cultural heritage.

In 2012, a committee of 12 park experts recommended a shift in the management of park resources in their publication, Revisiting Leopold. The committee recommended that goal of NPS in managing their parks should be "to steward NPS resources for continuous change that is not yet fully understood, to preserve ecological integrity and cultural and historical authenticity...(Colwell et al. 2012, 11).” However, historical authenticity is a slippery concept, which describes a complex if not impossible standard for reconstruction. Sites change overtime, as do the meaning those sites hold and the environment that hosts them. Authenticity as perceived by a tourist is very different than authenticity as perceived by a manager or another site user (Tunbridge and Ashworth 1996). And the modern tourist uses of the site may mean that the current and authentic features at a historic site are those that make tourists comfortable such as benches (2015).

In 2014, Director Jarvis of NPS released a policy memorandum that declared that the management of cultural resources in the face of climate change will require hard decisions, such as which cultural sites will be allowed to descend into the sea due to extreme coastal erosion (Jarvis 2014). In 2016, NPS released key publications that address and guide park actions in managing coastal cultural resources in the face of climate change, including: "Director's Order \#100," the Coastal Adaptation Strategies Handbook, and the Cultural Resources Climate Change Strategy. Director's Order $\# 100$, redefines integrity of a cultural resources as the ability to "convey its full historical, cultural, and scientific significance (Jarvis 2016, 18).” Although the 
subsequent presidential administration rescinded Director's Order \#100, park managers continue to work to preserve the resources in their parks. Cultural Resource Climate Change Strategy points out that past adaptability needs to relate to decisionmaking procedures in the face of climate change. Seven adaptation strategies for cultural resources are no active intervention, offsetting stress, improving resilience, managing change, relocating/facilitating movement, documenting and releasing, or interpreting the change (Rockman et al. 2016).

\section{Materials and Methods}

Within this broader pattern of changing management priorities, managers in individual parks work with both the national directives and the environmental features, cultural resources, and regional contexts of their individual parks. This research examines how park managers apply national priorities in local park contexts overtime and uncovers how climate change adaptation directives for cultural resources are or aren't manifesting in these spaces. The three national parks in this study are Colonial National Historical Park in Virginia, Gulf Islands National Seashore in Florida and Mississippi, and San Francisco Maritime National Historical Park in California. I selected sites using an information-oriented process, based on the potential research

outcomes at the site (Yin 2003; Flyvbjerg 2006). I selected three case study sites from a pool of coastal sites managed by the National Park Service. Within this pool, I used a maximum-variation approach because this approach can yield valuable information about patterns that manifest despite the contrasting features of the sites (Flyvbjerg 2006). I selected case sites that represented different NPS regions, coastal 
characteristics, climate change adaptation work previously undertaken, and artifacts and historical themes. Table 5 shows the location and description of the case study selection criteria and how each site adheres to the criteria.

Table 5. Case study sites and selection criteria.

\begin{tabular}{|c|c|c|c|c|c|}
\hline Park & $\begin{array}{l}\text { Assessed } \\
\text { Climate } \\
\text { Change Risk } \\
\text { Factor }\end{array}$ & $\begin{array}{l}\text { Park Location } \\
\text { NPS Region }\end{array}$ & $\begin{array}{l}\text { Coastal } \\
\text { Characteristics } \\
\text { and } \\
\text { Morphologies }\end{array}$ & $\begin{array}{l}\text { Vulnerability } \\
\text { Assessment } \\
\text { Process }\end{array}$ & $\begin{array}{l}\text { Artifacts and } \\
\text { Historical } \\
\text { Themes }\end{array}$ \\
\hline $\begin{array}{l}\text { Gulf } \\
\text { Islands } \\
\text { National } \\
\text { Seashore }\end{array}$ & $\begin{array}{l}81 \% \text { high } \\
\text { exposure (Peek } \\
\text { et al. 2015) }\end{array}$ & $\begin{array}{l}\text { Florida and } \\
\text { Mississippi, } \\
\text { Southeast } \\
\text { Region }\end{array}$ & $\begin{array}{l}\text { Barrier island } \\
\text { system }\end{array}$ & $\begin{array}{l}\text { Completed } \\
\text { through the } \\
\text { Geoscientists- } \\
\text { in-the-Parks } \\
\text { Program } \\
\text { (Toscano 2004) }\end{array}$ & $\begin{array}{l}\text { Spanish } \\
\text { colonial, Civil } \\
\text { War, World } \\
\text { War II, Native } \\
\text { American } \\
\text { archaeological } \\
\text { sites }\end{array}$ \\
\hline $\begin{array}{l}\text { Colonial } \\
\text { National } \\
\text { Historical } \\
\text { Park }\end{array}$ & $\begin{array}{l}\text { Projected sea } \\
\text { level rise and } \\
\text { coastal changes } \\
\text { (Schupp, } \\
\text { Beavers, and } \\
\text { Caffrey 2015) }\end{array}$ & $\begin{array}{l}\text { Virginia, } \\
\text { Northeast } \\
\text { Region }\end{array}$ & $\begin{array}{l}\text { Tidal river } \\
\text { system, marshes }\end{array}$ & $\begin{array}{l}\text { Underway } \\
\text { under the } \\
\text { leadership of } \\
\text { the NPS } \\
\text { Northeast } \\
\text { Region Climate } \\
\text { Change } \\
\text { Program }\end{array}$ & $\begin{array}{l}\text { American } \\
\text { Revolution, } \\
\text { archaeological } \\
\text { sites, early } \\
\text { colonial }\end{array}$ \\
\hline $\begin{array}{l}\text { San } \\
\text { Francisco } \\
\text { Maritime } \\
\text { National } \\
\text { Historical } \\
\text { Park }\end{array}$ & $\begin{array}{l}43 \% \text { high } \\
\text { exposure (Peek } \\
\text { et al. 2015) }\end{array}$ & $\begin{array}{l}\text { California, } \\
\text { Pacific West } \\
\text { Region }\end{array}$ & $\begin{array}{l}\text { Heavily altered } \\
\text { by human } \\
\text { endeavors, } \\
\text { rocky and } \\
\text { sandy, tidal } \\
\text { mudflats } \\
\text { shoreline }\end{array}$ & $\begin{array}{l}\text { Partner projects } \\
\text { have examined } \\
\text { certain features } \\
\text { of the park; No } \\
\text { overall project } \\
\text { underway }\end{array}$ & $\begin{array}{l}\text { Coastwise } \\
\text { transport, } \\
\text { Chinese } \\
\text { immigration, } \\
\text { African- } \\
\text { American } \\
\text { maritime } \\
\text { experience } \\
\end{array}$ \\
\hline
\end{tabular}

At each case study site, I used complimentary qualitative methods of interviews and document analysis to build a framework to understand climate change management of cultural resources. I analyzed documents including past management plans, interpretive plans, site plans, correspondence of managers, Civilian Conservation Corps reports, management photographs, and annual reports (Creswell 2014; Greene, Caracelli, and Graham 1989). U.S. Army Corps and Congressional records are published annually, showing change in the perspectives over time. I 
collected and systematically analyzed historic documents and secondary on each of the parks. I analyzed this information for both content and thematic connections (AttrideStirling 2001; Krippendorf 1996). I also systematically grouped, or coded, according to topic and claim and analyzed to determine important themes and causal patterns in interviews (Babbie 2013; Toulmin 2003; Attride-Stirling 2001; Neuman 1997). Table 6 shows the archives visited and collections used in this study.

Table 6. Archival collections referenced.

\begin{tabular}{|c|c|c|}
\hline $\begin{array}{l}\text { Archive } \\
\text { Visited }\end{array}$ & National Park Focus & Collections Viewed \\
\hline $\begin{array}{l}\text { Library of } \\
\text { Congress } \\
\text { Archives, } \\
\text { Washington, } \\
\text { DC }\end{array}$ & $\begin{array}{l}\text { Gulf Islands National } \\
\text { Seashore; Colonial National } \\
\text { Historical Park }\end{array}$ & $\begin{array}{l}\text { Jamestown Tercentenary Exposition Collection; } \\
\text { Historic American Buildings Survey }\end{array}$ \\
\hline $\begin{array}{l}\text { National } \\
\text { Archives, } \\
\text { College Park, } \\
\text { MD }\end{array}$ & All Parks & $\begin{array}{l}\text { Administrative Records of the National Park } \\
\text { Service }\end{array}$ \\
\hline $\begin{array}{l}\text { University of } \\
\text { California, } \\
\text { Berkeley, } \\
\text { Bancroft } \\
\text { Archives, } \\
\text { Berkeley, CA }\end{array}$ & $\begin{array}{l}\text { San Francisco Maritime } \\
\text { National Historical Park }\end{array}$ & $\begin{array}{l}\text { Regional Oral History Office, San Francisco Bay } \\
\text { and Waterfront Collection, 1900-1965; Regional } \\
\text { Oral History Office, Maritime History and } \\
\text { International Longshoremen Series }\end{array}$ \\
\hline $\begin{array}{l}\text { University of } \\
\text { West Florida } \\
\text { Archives, } \\
\text { Pensacola, FL }\end{array}$ & $\begin{array}{l}\text { Gulf Islands National } \\
\text { Seashore }\end{array}$ & $\begin{array}{l}\text { Gulf Islands National Seashore Records; Fort } \\
\text { Barrancas Papers; Individual File Collections }\end{array}$ \\
\hline $\begin{array}{l}\text { Maritime } \\
\text { Research } \\
\text { Center, San } \\
\text { Francisco, CA }\end{array}$ & $\begin{array}{l}\text { San Francisco Maritime } \\
\text { National Historical Park }\end{array}$ & $\begin{array}{l}\text { A Tribute to Mendocino Coast Commercial } \\
\text { Fishing; Don Maskell photographs }\end{array}$ \\
\hline $\begin{array}{l}\text { Library of } \\
\text { Virginia, } \\
\text { Richmond, } \\
\text { VA }\end{array}$ & $\begin{array}{l}\text { Colonial National Historical } \\
\text { Park }\end{array}$ & $\begin{array}{l}\text { Administrative Records of the National Park } \\
\text { Service }\end{array}$ \\
\hline $\begin{array}{l}\text { University of } \\
\text { Rhode Island, } \\
\text { Kingston, RI }\end{array}$ & All Parks & $\begin{array}{l}\text { Government Publications-Army Corps of } \\
\text { Engineers Records; California Department of Fish } \\
\text { and Game }\end{array}$ \\
\hline
\end{tabular}

In addition to document analysis, I conducted interviews with key informants because the experiences and knowledge of current cultural resource managers is not 
yet represented in the public textual record. Key informant interviews can provide quality information, that is very specific to the situation in question (Marshall 1996b). At each case study site, I contacted the Chief of Cultural and/or Natural Resources, the Chief of Interpretation, staff responsible for running climate change initiatives within the park, and members of the curatorial staff, for interviews (Guest 2015; Johnson and Hruschka 2015; Babbie 2013; Marshall 1996a). Table 7 shows the number of key informant, focus group, and workshop interviews at each location.

I conducted interviews in a semi-structured manner, with interviews split into three sections, with additional follow-up questions as needed. The interview protocol sought the informant's observations and informed opinions given their intimate understanding of, experience with, and input in the management of cultural resources in NPS. During the interview procedure, I asked key informants to share their assessment of climate change risks to cultural resources in the park, insights on interpretation of change to these resources, and details of the decision-making process for cultural resource management in the park. A final question, asked informants whether there were gaps in our conversation based on their understanding of the topic. This question allowed respondents to fill in any perceived gaps in our conversation. 
Table 7. key informant interview formats and locations.

\begin{tabular}{|l|l|l|l|l|l|}
\hline $\begin{array}{l}\text { Case } \\
\text { Study } \\
\text { Site }\end{array}$ & $\begin{array}{l}\text { Potential } \\
\text { Informants } \\
\text { Contacted }\end{array}$ & $\begin{array}{l}\text { Number } \\
\text { of Key } \\
\text { Informant } \\
\text { Interviews }\end{array}$ & $\begin{array}{l}\text { Number } \\
\text { of Focus } \\
\text { Group } \\
\text { Interviews }\end{array}$ & $\begin{array}{l}\text { Workshop } \\
\text { Observation }\end{array}$ & $\begin{array}{l}\text { Total } \\
\text { Number of } \\
\text { Informants }\end{array}$ \\
\hline $\begin{array}{l}\text { San } \\
\text { Francisco } \\
\text { Maritime } \\
\text { National } \\
\text { Historical } \\
\text { Park }\end{array}$ & 4 & 0 & 2 & 0 & 5 \\
\hline $\begin{array}{l}\text { Pacific } \\
\text { West } \\
\text { Regional } \\
\text { Office }\end{array}$ & 4 & 1 & 1 & 0 & 4 \\
\hline $\begin{array}{l}\text { Gulf } \\
\text { Islands } \\
\text { National } \\
\text { Seashore }\end{array}$ & 4 & 3 & 1 & 0 & 5 \\
\hline $\begin{array}{l}\text { Southeast } \\
\text { Regional } \\
\text { Office }\end{array}$ & 3 & 1 & 0 & 0 & 1 \\
\hline $\begin{array}{l}\text { Colonial } \\
\text { National } \\
\text { Historical } \\
\text { Park }\end{array}$ & 4 & 3 & 0 & 2 & 2 \\
\hline $\begin{array}{l}\text { Northeast } \\
\text { Regional } \\
\text { Office }\end{array}$ & 2 & 2 & 0 & 2 & \\
\hline Total & 21 & 9 & 4 & 4 & \\
\hline
\end{tabular}

I then grouped the totality of the information and looked for patterns and trends

(Creswell 2014; Babbie 2013; Ritchie and Spencer 2002). While the discussions

surrounding climate perspectives and continuing discussions of climate change at individual case study sites is specific to these geographic locales, the broader national and international patterns that influenced the shifting perspectives and management of climate volatility and change overtime mirror or share drivers with other communities. As broad patterns of national management of cultural resources change in response to shifting priorities and accompanying policies, these changes manifest differently in various locations. Critics of case study research question whether the results of such 
projects translate to other sites (Herbert 2010). The cases are illustrative rather than representative in nature and the differences between the cases represent the differences in the individual contexts of the sites.

\section{Results: Perceptions of Landscape and Change in Three National Parks}

Management goals on the landscape are associated with the local context as well as broader national uses and priorities. And managers' perceptions of change and permanence on the landscape are directly related to the management goals of the landscape. Alterations made to the landscape to preserve a particular site or use were not identified as change because they served to maintain a stable condition for a specific use. Military managers representing the government of the United States built defensive structures in coastal spaces to guard land and commercial uses. As people began to request recreational space, coastal managers addressed this use of coastal areas by constructing and changing the landscape to make sites suitable for this purpose. During the early $20^{\text {th }}$ century, as national interest in historic preservation grew, the goals of the management of certain coastal structures from maintaining forts, for example, for a military use, updating the spaces as necessary, to preserving the sites for commemorative purposes. Policies including the National Historic Preservation Act of 1966 codified these growing priorities. As these three landscapes became parks, managers made changes to the landscape to create specific historic or educational situations for visitors, often with the goal of recreating or restoring a previous state or situation. Managers at GUIS reintroduced species in areas designated as wilderness and managers in COLO removed structures on the landscape that were 
newer than the time period deemed significant, while also constructing buildings that would serve park needs.

\section{Colonial National Historical Park, Virginia}

Bordered by the York River to the northeast and the James River to the south, Colonial National Historical Park (COLO) includes Jamestown Island, Yorktown, and a 23-mile scenic road corridor that connects the two, shown in Figure 10. The landscape of coastal Virginia is defined by ongoing sand and sediment accretion and erosion along the numerous rivers, creeks, and tributaries and these processes both shape the patterns of human construction, navigation, and use in the area (Hardaway, Jr. and Byrne 1999; Byrne and Anderson 1977). Both ongoing and storm-related wind and wave action contribute to patterns of sediment movement. However, man-made features on the rivers such as bulkheads and revetments and anthropogenic climate change also impact the patterns of shoreline change along both the James and York rivers (Hardaway, Jr. and Byrne 1999). Jamestown Island, Yorktown Battlefield, and Williamsburg, Virginia hosted the first permanent English settlement in the modern United States, an important battle in the resolution of the American Revolution, and the capital of the colonies, respectively. As such, these locations each played an important role in American history, as well as a role in the intentional curation of both the American and Virginian origin stories (Kiracofe 2002). 


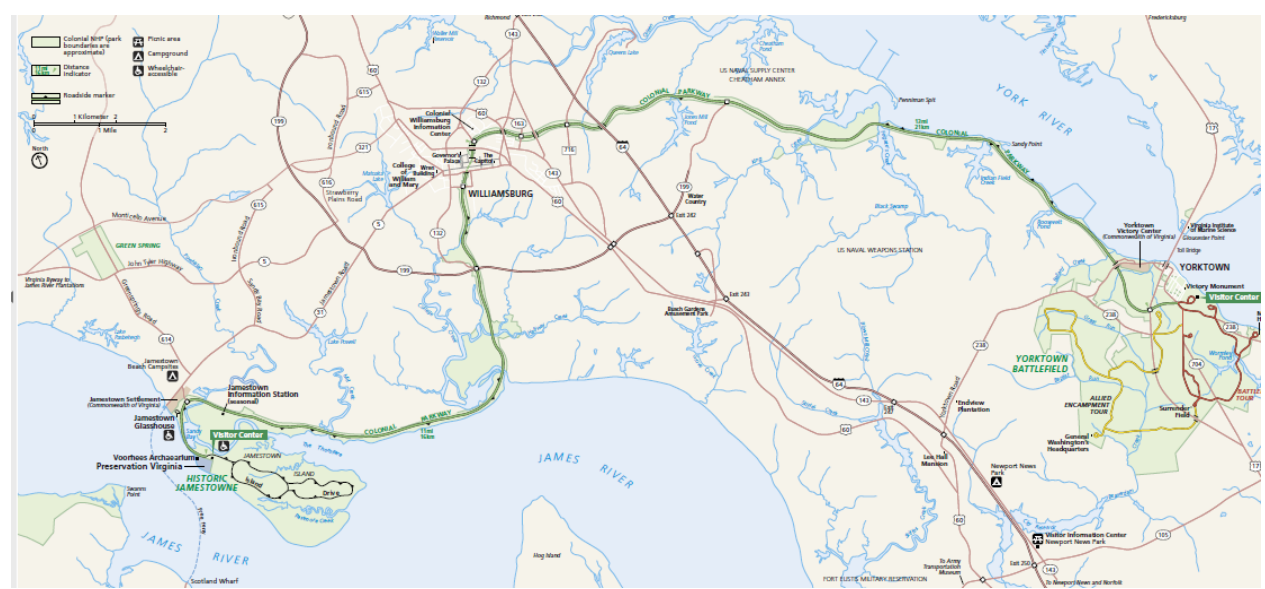

Figure 10. Colonial National Historical Park.

For over a century, shoreline construction and design in the area that is now COLO has focused on creating and maintaining the landscape in a way that commemorates, memorializes, and studies these early events. Initially used for residential, agricultural, and military purposes, in the late $19^{\text {th }}$ century, the Army Corps of Engineers (Corps) and later the National Park Service (NPS) designed and managed this riparian area as a commemorative space for visitors to study and celebrate American history. Overtime, both the ongoing erosion of the York and James River shorelines and updates to the scope and methods of research, as well as expectations of a commemorative space, have led managers to establish different management goals, expectations of permanence, rationales for change, and responses to environmental change within the area. As evidence of management uses and priorities on the landscape, as well as important resources for preservation and use, cultural resources including historic structures, archaeological sites, and cultural landscapes reveal these changing patterns of management. As managers address the impacts of anthropogenic climate change on the cultural resources of COLO, managers are faced with new environmental changes and conditions in the JamestownYorktown landscape. 
At COLO, management goals have changed as a result of national priorities and scientific developments, from focusing on restoring the landscape to appear as it had during the periods of site significance to the United States, to the restoration of landscape where the systems and processes including coastal erosion more closely resemble a perceived original or desirable ecological status. Through this transition, as managers are confronted with climate change, management focus on inventories and processes are influencing how managers perceive climate change risk on the landscape. From the early protection of archaeological sites, to the later reconstruction of the 1607 shoreline extent of the island, followed by inventories of archaeological sites and erosion risk on Jamestown Island, the current management focus is influencing how managers are perceiving climate change and climate change impacts at COLO. As the management of cultural resources at COLO has become increasingly focused on resource inventories and archaeological research, managers have framed climate change risk relative to damages to individual sites. By framing climate change risk in this way, the potential solutions to the problem are limited to a sliding scale of options for individual sites ranging from protecting the site in place to allowing the site to erode (Beavers, Babson, and Schupp 2016).

\section{Protecting Historic Monuments and Developing Commercial Navigation, Army Corps of Engineers, 1881-1930}

The Corps' management goals for the Yorktown and Jamestown area were to enable navigation and commerce along the York and James rivers, protect the Yorktown Battlefield Monument, and protect the remaining archaeological materials 
in the location of the historic English settlement on Jamestown Island. All of these goals necessitated and justified engineering projects and changes to the environment of the York and James rivers. In response to ongoing environmental change caused by erosion, the Corps built a 1,500-foot seawall along the southwestern portion of Jamestown Island, assigned an enlisted man to guard the Yorktown Monument, and dredged channels in the York and James rivers (Papers Relative to the Completion of the Monument of Yorktown 1885). Between 1894 and 1901, the U.S. Army Corps of Engineers built a seawall along the waterfront of Jamestown Island to protect the land and artifacts associated with the early English settlement. With the national backdrop of the Antiquities Act, and locally the completion of Colonial Williamsburg, these management measures preserved the commemorative use of the site, ensuring that archaeological remains on the island, as well as the Yorktown Monument, would remain intact for visitors to see.

The Corps did not see the shoreline as a permanent or fixed feature on the landscape, but rather saw the erosion of the shoreline as something they could halt when and where they deemed necessary. The Corps recognized that shoreline erosion was an ongoing threat to the archaeological sites on Jamestown Island; however, after the construction of the initial seawall, the Corps did not believe that the commercial potential of the archaeological resources on Jamestown Island, owned by the Association for the Preservation of Virginia Antiquities, today Preservation Virginia (PV), warranted the construction of additional seawall yardage. The quarters for the enlisted man assigned to care for the Yorktown Monument declined. Willing to protect the original settlement site on Jamestown through coastal engineering, the Corps' 
rationale for creating environmental change in the area was focused on development through commerce and navigation.

\section{Conveying a Historic Past through a Commemorative Park Landscape, National Park Service, 1930-present}

In 1930, Congress designated Colonial National Monument and the management responsibility for areas of the historic triangle transitioned from the Corps to NPS. NPS managers saw coastal erosion as a direct threat to the colonial history of the United States and worked to restore the shoreline of Jamestown Island to its 1607 position and the landscape of Yorktown Battlefield to its 1781 appearance (Peterson 1931b, 1931a; Albright 1930). Under NPS purview, park managers would transform the landscape of COLO with the goal of inspiring and educating the American public about their heritage by presenting a landscape that resembled that witnessed by early English settlers and Revolutionary War soldiers. Less than three years after NPS took over the site, the Civilian Conservation Corps formed under New Deal legislation to both create work for unemployed men during the Great Depression and complete desired public works projects, especially in the national parks, through this labor. NPS managers instructed Civilian Conservation Corps workers graded and sodded shoreline cliffs to prevent the erosion of soil and armored the shoreline at the water's edge (Toms 1931). The shoreline engineering of Jamestown Island during this time served to both protect archaeological sites in some locations, as well as preserve the physical extent of the shoreline that managers believed existed when English settlers first arrived in the area. They led Civilian Conservation Corps members in 
sloping shorelines in order to both prevent erosion and create a modern, clean park shoreline.

Although NPS managers recognized that shoreline erosion along the James and York rivers was an ongoing process, these engineering projects indicate that managers believed they could reject shoreline change and establish more permanent boundaries between land and water through engineering. In addition to this idea of creating more permanent shorelines, when hurricanes and storms affected the park, the goal of the Civilian Conservation Corps workers was to remove evidence of the storms from the park, similarly suggesting that park managers wanted to present a stable and consistent environment, rather than one of change and fluctuation. Always a focus at COLO, at the national level, the Historic Sites Act of 1935 encouraged the study and excavation of archaeological sites. As archaeologists and Civilian Conservation Corps members worked to recover archaeological materials, park managers capped and sealed brick remains of colonial structures and display them for the public (Cotter 1955). Similarly, the park continued a program of shoreline stabilization which aimed to maintain the boundary between land and water in place. All of these views contributed the place, with the shoreline location, as well as the landscaping of Yorktown Battlefield and the “approximate virginal aspect" of Jamestown Island retained qualities indicative of the unique characteristics of the location and an intentional representation thereof. More than just preserving archaeological sites and Yorktown Battlefield, managers were creating a park space by manicuring shorelines, erasing storm damages, and engineering shorelines to their projected extent in 1607 and the tree-line at Yorktown Battlefield to its projected extent in 1781 (Peterson 1931b). NPS managers continued 
to alter the coastal environment of the park to approximate that of 1607 or 1781 through the Mission 66 programming of 1966 which celebrated the $50^{\text {th }}$ anniversary of the Organic Act that founded NPS by encouraging park visitation.

In subsequent decades, national legislation including the National Historic Preservation Act and National Environmental Policy Act, motivated by public conservation and preservation movements, as well as disciplinary developments in ecology and archaeology began to alter the way NPS managed cultural and natural resources. Building from this legislation, in the 1980s, parks including COLO began managing natural systems, and later cultural resources, through inventories and monitoring procedures. This shift in management approach led managers to consider individual sites and structures and at COLO, managers worked to identify and inventory known archaeological sites, identifying these features as the key cultural resources on the landscape, rather that the reconstruction of the shoreline to approximate the 1607 location. More recently, NPS began working on larger units of

analysis, examining interconnected systems of cultural landscapes, which include the individual archaeological and historic components of sites as well as the flora, fauna, visitor features, and spatial arrangement (Webb 1987). NPS managers began to examine the ecosystem processes and interactions of natural resources in addition to monitoring individual species (Dallas, Berry, and Ruggiero 2013). This management development continues to influence the NPS approach to climate change.

Identifying Climate Change Risk and Setting Landscape Preservation Priorities, 2009-present 
NPS managers at COLO have worked to preserve cultural resources including archaeological sites, historic structures, and cultural landscapes from damage and deterioration caused by weathering, erosion, wind damage, looting, excessive use, and various other factors, the effects of anthropogenic climate change have started to compound the deterioration of these resources. The goals of NPS for cultural resource management include preserving the resource for the benefit of future generations, as well as research, education, and interpretation. While anthropogenic climate change has been affecting the coastline of the United States since long before 2009, the year marks the first NPS publication on climate change and cultural resources, as well as the general time at which all respondents indicated NPS began discussing the topic.

Park managers recently conducted and participated in a climate change vulnerability assessment process to gather information required to begin planning adaptation strategies to address climate change impacts (Ricci et al. in review). At COLO, managers were most concerned with buried artifacts eroding away on Jamestown Island and along the Yorktown waterfront. In response to the effects of climate change, in addition to the ongoing threats to cultural resources, managers sometimes elect to alter both the park and these resources by excavating at risk sites. The process of document and release or mitigating archaeological sites represents a shift from protecting the shoreline to protecting the learning and research potential of specific sites within the park. Similarly, a 2016 report published by NPS recommends the removal of certain coastal protection structures along Jamestown Island to allow for the continuation of coastal erosion and accretion processes as a climate adaptation strategy (Nordstrom and Jackson 2016). However, this report suggests that managers 
retain shoreline protections in areas that protect significant cultural resources. In interviews, COLO managers articulated that the shorelines of the York and James rivers were never permanent, but always shifting systems. However, this management approach of protecting certain areas but not others suggests that managers continue to see shoreline engineering as an option for making portions of the shoreline permanent to meet management preservation goals (Army Corps 2013). While earlier management procedures identified the maintenance of shorelines as an authentic presentation of space, this transition suggests that a new standard for space may be the process of the shoreline rather than the line it holds or the species that populate the land area.

NPS documents suggest that managers need to prioritize and make choices about which sites to excavate, document, protect, or allow to succumb, have the potential to reroute or redefine the research priorities of Jamestown Island and Yorktown Battlefield. Although managers in the past have made clear statements about what is and isn't American at this site, increasing scientific understandings, a broadening scope of archaeological research, techniques, and technologies, and an expansion of what constitutes an American identity, has changed the priorities on which managers would be making decisions in the face of climate change. In addition to the colonial archaeological sites identified and studied in the decades after COLO was founded, park managers now consider much older sites, dating to almost 10000 years before present in the cultural resource inventory of the park. Today, managers have inventories of each known archaeological site, historic structure, and landscapes of modern and historical significance. Rather than making choices based on the 
commemorative use of the landscape, managers indicated that climate change decisions should be based on the research potential of archaeological sites, prioritizing age, rarity, and the structural integrity of sites. 
Table 8. illustrates the management goals, ideas of permanence, rationales for creating change and responses to change in Jamestown-Yorktown area from 1894 through the present.

\begin{tabular}{|c|c|c|c|c|}
\hline \multicolumn{2}{|c|}{ Colonial National Historical Park } & & & \\
\hline \multirow{4}{*}{ 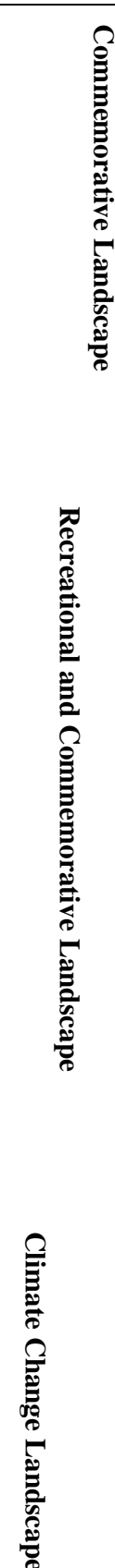 } & $\begin{array}{l}\text { RATIONALE FOR } \\
\text { CHANGE: "Abrasion of the } \\
\text { shore of the island had been } \\
\text { going on for years, and had } \\
\text { reached a condition that } \\
\text { required checking if the old } \\
\text { landmark was } \\
\text { to be preserved." (Chief of } \\
\text { Engineers } 1897,1349 \text { ) }\end{array}$ & & & \\
\hline & $\begin{array}{l}\text { GOAL: To "ornament and } \\
\text { improve the park in an } \\
\text { appropriate manner" (Bland } \\
\text { 1926) }\end{array}$ & $\begin{array}{l}\text { EXPECTATION OF } \\
\text { PERMANENCE: "Part } \\
\text { of the old island, which } \\
\text { became home to those } \\
\text { earliest of English } \\
\text { pioneers, has } \\
\text { disappeared, washed } \\
\text { away by the James } \\
\text { River. Now an } \\
\text { interesting seawall, } \\
\text { erected by the United } \\
\text { States Government } \\
\text { prevents further } \\
\text { erosion." (Albright } \\
\text { 1930, 2) }\end{array}$ & & \\
\hline & $\begin{array}{l}\text { GOAL: "If Colonial is to } \\
\text { yield its maximum in } \\
\text { inspiration, ... the proper } \\
\text { environment is required. } \\
\text { This includes a return to the } \\
\text { original scene that marked } \\
\text { the areas period of maximum } \\
\text { greatness." (National Park } \\
\text { Service } 1954,3)\end{array}$ & $\begin{array}{l}\text { RATIONALE FOR } \\
\text { CHANGE: "Restore } \\
\text { and maintain the } \\
\text { primitive "wild" } \\
\text { character of Jamestown } \\
\text { Island outside those } \\
\text { areas containing } \\
\text { physical remains of the } \\
\text { settlement." (National } \\
\text { Park Service 1969) }\end{array}$ & $\begin{array}{l}\text { EXPECTATION OF } \\
\text { PERMANENCE: "No } \\
\text { additional soil loss } \\
\text { between the breakwaters } \\
\text { was seen, indicating this } \\
\text { project is a success, at } \\
\text { least until now." } \\
\text { (Sullivan 1981) }\end{array}$ & \\
\hline & $\begin{array}{l}\text { RATIONALE FOR } \\
\text { CHANGE: "These structures } \\
\text { were designed to stabilize } \\
\text { the shoreline to protect } \\
\text { cultural resources and have } \\
\text { been mostly } \\
\text { successful...However, the } \\
\text { coastal engineering } \\
\text { structures have also likely } \\
\text { altered the natural sediment } \\
\text { transport processes in the } \\
\text { region." (Dallas, Berry, and } \\
\text { Ruggiero 2013,27) }\end{array}$ & $\begin{array}{l}\text { EXPECTATION OF } \\
\text { PERMANENCE: “At } \\
\text { the moment } 24 \\
\text { [Jamestown Island } \\
\text { archaeological] sites are } \\
\text { currently in the process } \\
\text { of } \\
\text { being destroyed or } \\
\text { transferred out of NPS } \\
\text { jurisdiction through } \\
\text { submergence." (Bassett } \\
\text { 2016, 11) }\end{array}$ & $\begin{array}{l}\text { RESPONSE TO } \\
\text { CHANGE: "The } \\
\text { historical significance of } \\
\text { the location of the } \\
\text { original Jamestown and } \\
\text { the archaeological value } \\
\text { of the artifacts known to } \\
\text { be in the ground, limit } \\
\text { the potential for allowing } \\
\text { portions of that site to } \\
\text { revert to natural } \\
\text { processes." (Nordstrom } \\
\text { and Jackson 2016, 77) }\end{array}$ & $\begin{array}{l}\text { GOAL: "Excavate } \\
\text { sites that cannot } \\
\text { be } \\
\text { saved...Conduct } \\
\text { further } \\
\text { investigation into } \\
\text { at-risk but poorly } \\
\text { understood sites." } \\
\text { (Ricci et al. 2017 } \\
\text { in preparation, 5) }\end{array}$ \\
\hline
\end{tabular}

Erosion of the shorelines of COLO has been the dominant feature of

environmental change in the park and climate change will continue along this vector,

likely increasing the speed and intensity of coastal erosion. Army Corps and early

NPS managers at COLO believed erosion changed the character of the landscape and 
affected both the archaeological resources and the ability of the public to experience a landscape that was authentic to that experienced by early English settlers and Revolutionary War soldiers. As NPS management became increasingly scientific, with monitoring programs and species restorations, COLO managers today see archaeological sites as units of research potential, the loss of which removes the possibility of generating and enhancing historical understanding. Table 8 shows illustrative quotes from the historic Army Corps management documents through quotes from interviews with current managers of COLO.

In the face of climate change, managers are focusing on preserving archaeological sites. Current managers of COLO indicated that one of the most acute issues faced by the park in terms of cultural resource preservation is a lack of staff. This suggests that managers view the response to climate change as an impact that requires human maintenance, work, and intervention. While managers indicated that the park landscape was never permanent, they also agreed that change was difficult to see and perceive because it was almost imperceptible, taking place a little at a time. In addition, many of the cultural resources at COLO are buried, making a change in resource conditions difficult to see or detect. While NPS management for natural resources favors the restoration of coastal processes such as erosion, in order to allow natural landscapes to migrate and exercise resilient and adaptive behaviors towards changing environmental conditions, managers concede that hardened shorelines may still be important to protect cultural resources. This suggests that while managers are working to adjust to climate change and believe the Tidewater coastlines have never been permanent, the approach to the climate change protection of cultural resources is 
still reliant on familiar management techniques and beliefs that portions of the shoreline can be made permanent.

\section{Gulf Islands National Seashore, Florida and Mississippi}

The landscape of the northern coast of the Gulf of Mexico is characterized by a system of sandy barrier islands, that fringe the coastal mainland and move and change with predominant currents, wave and storm activity. These processes shape both the natural landscape and the patterns of human settlement and activity along the Gulf Coast. In addition to the natural motion of these islands, man-made dredge channels, groins, and other alterations can alter patterns of sand accretion and erosion. These barrier islands protect the mainland from the full force of hurricane strikes and create a system of protected bays. Gulf Islands National Seashore (GUIS) spans from Okaloosa outside Fort Walton, Florida, to Cat Island in Mississippi. Early American management in the area now occupied by the seashore focused on military defense of Gulf Coast land and industry. Congress designated the seashore in 1970 to preserve the beaches along the Gulf for public recreation, as well as the historic value of the forts in the area ("Gulf Islands National Seashore History and Status Outline Summary," n.d.) GUIS was created to reserve more coastal areas for water-based recreational opportunities (National Park Service, n.d.) 


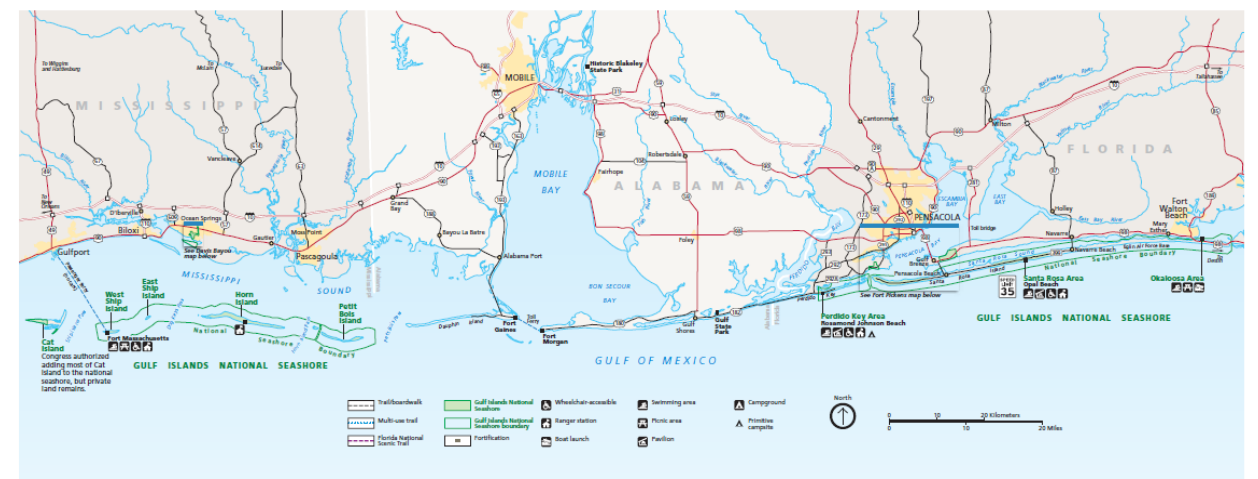

Figure 11. Gulf Islands National Seashore.

For almost two centuries, the United States federal and state governments, first through the military and later through NPS, have modified and altered the Gulf Coast barrier islands to arrange the space to suit their military and later recreational purposes. Initially, the U.S. Army constructed imposing masonry fortifications around Pensacola Bay in order to claim and maintain the area as part of American territory. Later, the military modified these shifting islands to accommodate new military technology before the area was transitioned to the purview of NPS to meet expanding recreational needs and demands. As the uses and needs in the area have changed, federal managers' goals, expectations of permanence, rationales for environmental change, and responses to change have shifted. The legacy of construction in the area, first for military purposes and later for recreational uses, is documented through both historic texts relating to the area and the artifacts and landscapes themselves. In addition to documenting the changes in management goals and perceptions, visitors to GUIS, as well as researchers, enjoy and use the cultural resources at the site. The archaeological site, historic structures and cultural landscapes in the park were all built on a substrate that moves with waves, winds, and hurricanes. In addition to these factors, anthropogenic climate change is beginning to impact the system. 
At GUIS, the management goals for the system have changed as the primary uses of the area have transitioned from military and defensive purposes to recreational and preservation-oriented outcomes. Originally focused on creating permanent military fortresses, current managers focus on preserving these fortresses, but also preserving access for park visitors to the historic structures and recreational spaces in the park. As managers are confronted with climate change, both the ongoing change in the barrier island setting and the management focus on recreational opportunities and preserving access is influencing how managers perceive the climate change risk on the landscape. Despite climate change, managers perceive preservation and daily maintenance as the biggest issues facing the park, the seasonal change in the system obscuring and overwhelming potential climate change impacts.

\section{Maintaining Political Claims through Military Presence, U.S. Army Corps of \\ Engineers and U.S. Navy, 1821-1960}

When West Florida became a part of the United States in 1821, the U.S. Army and Navy built facilities at Pensacola to protect American military and commercial interests in the region. Despite evidence that previous Spanish forts had been damaged by storms and overrun with sand, American military engineers expected to construct permanent structures in the area and selected building materials accordingly ("Message from the President of the United States, With a Report from the Secretary of War, Transmitting the Inspection Returns of Brevet Major General Gains, for 1826 and 1827, Relating to the Organization of the Army and Militia" 1829, "Report of the Secretary of the Navy: Plans and Estimates for the Construction of a Permanent Wharf 
and a Dry Dock at Pensacola" 1844). However, after one of the three Army forts in Pensacola Bay eroded into the sand, the Army Corps decided to build jetties to maintain the land that once held the fort in order to build updated gun batteries (Report of the Chief Engineer to the Secretary of War 1848). To further enhance commercial activity in the area, the Army Corps began dredging efforts in Pensacola Bay in 1879 and in the Mississippi Barrier Islands soon thereafter (Chief of Engineers 1879). As the needs and uses of the area changed, the military managers of the area created or responded to environmental change in the area to accommodate the management priorities of commerce and military defense.

\section{Recreational Beaches and Fishing Spaces, National Park Service, 1960-present}

As the area that is currently GUIS transitioned to a primarily recreational space, management alterations of the environment to construct and preserve the forts and structures shifted and managers began to alter the landscape to create national park. During the 1960s and 1970s, policies such as the National Environmental Policy Act and the Endangered Species Act both encouraged the managing, monitoring and protecting of species as components of the environment and other ecological features. At GUIS, NPS managers worked to reintroduce wolves, the Perdido Key Beach Mouse, and remove feral pig populations from the island (Pridemore 1984; "Gulf Islands National Seashore 1990 Annual Narrative Report” 1990). These changes all worked to create or recreate a place or setting on the island perceived to be more akin to the setting before human manipulation. Although these management practices affected species, they contributed to the recreational setting of the park. While NPS 
managers resisted the historic changes that caused the loss of these species in these areas, they accepted the alteration of the ecosystem resulting from the reintroduction of the species. While NPS managers accepted changes such as the reintroduction of species that aligned with the new management goals in the area, managers resisted the motion of the barrier islands, replacing sand around the base of Fort Massachusetts and other portions of the park.

The new management goals of preserving the fort structures changed the expectations of permanence in the environment from a focus on maintaining the land area surrounding the fort as needed for updating military technologies to maintaining the fort itself as a historic structure. While the Army Corps could construct new batteries to serve defensive purposes at the site of a fort that eroded away, NPS managers working to preserve a historic fort had to maintain the land in place. And NPS management goals for the cultural resources in the park established that they would "stabilize or reverse deterioration of natural and historical resources" ("Purpose of the National Seashore" 1973). This response to environmental change focused on maintaining the features of the place, including the beaches and forts for the new recreational uses in the area. As NPS managers worked to create a park environment, their preservation efforts focused on the forts as these sites were designated in the enabling legislation for the park. Some historic structures including Fort McRee and the Ship Island Quarantine Station had already deteriorated with NPS took over the area and managers allowed these structures to further disintegrate.

\section{Separating Barrier Island Turnover from Climate Change, 2009-present}


National level climate change policies for cultural resources in NPS encourage managers to plan for the impacts of climate change on these resources. Managers perceived climate change as an "existential" threat to the park, where sea level rise could threaten the very existence of the park. Managers spoke to the nature of the forts protected by the park, highlighting that they cannot move forts and the management options include higher seawalls or snorkel tours. GUIS has recently acquired ferries that will transport visitors from Pensacola Beach to Fort Pickens if Fort Pickens road is not rebuilt after future hurricane damages. Both the ferry service and the suggesting of a change in how NPS presents the park to visitors suggests that GUIS managers are thinking about changing use patterns in the park in the face of climate change.

Managers are thinking about climate change in terms of resource presentation and changes to visitor experience rather than a built solution or prioritizing and selecting resources loss or abandonment. Congress designated GUIS for recreation, amongst other purposes and the access to coupled recreational and historical sites such as Fort Pickens represents a change in how visitors engage with the cultural resources in the park and a change in the visitation process.

Recently, the Mississippi Coastal Improvements Project (MsCIP) will further alter the shape of the Mississippi Barrier Island Chain by filling in the breach of Ship Island caused by Hurricane Camille in 1969 with the stated purpose of protecting the Mississippi coast from hurricanes (U.S. Army Corps of Engineers Mobile District 2016). The purpose of MsCIP is to "[restore] the Mississippi Barrier Islands as part of a comprehensive plan to increase the resiliency of the coast to future storm events (U.S. Army Corps of Engineers Mobile District 2016, ii).” The plan calls for the 
placement of up to 22 million cubic yards of sand in four locations: the area between West and East Ship Islands to reconnect the islands, the east end of Petit Bois Island, the east end of East Ship Island, and the east end of Cat Island (U.S. Army Corps of Engineers Mobile District 2016). The Corps intends for this sand will slow the approach of hurricanes and help to buffer hurricane system impacts on the coast of Mississippi (U.S. Army Corps of Engineers Mobile District 2016). The Corps justifies this action within a national park by suggesting that this action protects cultural resources and restores landforms disturbed by humans (U.S. Army Corps of Engineers Mobile District 2016).

Although there is a long history of man-made structures and sand fill in the Mississippi Islands to protect from hurricanes, this project creates protective barriers for the Mississippi coastline, rather than for specific forts or other cultural resources. The MsCIP discusses climate change as an accelerating force in the loss of barrier island chains and suggests that given this forcing as well as channel dredging, the MsCIP outcomes will mimic a natural state. Unlike earlier projects that restored sand around only Fort Massachusetts or on Perdido Key (“GUIS Advisory Committee Meeting Minutes" 1980; Pridemore 1983), the Corps does not propose this project as a return to an earlier state but does suggest that correcting the natural motion of barrier islands, based on the location of static shipping channels, is a restoration effort rather than a modification to an unprecedented state. While the motivation for this environmental modification is enhancing protection of the shoreline that is more vulnerable to increasing storm trends with climate change, the creation of islands and the artificial fill of a hurricane breach indicates that allowing the natural rollover of the 
islands is less important than the function of the islands. This project shows that the Army Corps of Engineers views the park land as part of a broader coastal system and process, rather than tied only to the recreational uses of the park. 
Table 9. management goals, ideas of permanence, rationales for creating change and responses to change in Pensacola and the Mississippi Barrier Islands overtime.

\begin{tabular}{|c|c|c|c|c|}
\hline \multicolumn{2}{|c|}{ Gulf Islands National Seashore } & & & \\
\hline \multirow{4}{*}{ 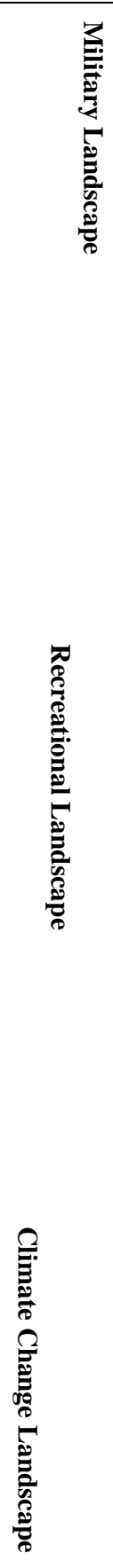 } & $\begin{array}{l}\text { MANAGEMENT } \\
\text { GOAL: "...the works for } \\
\text { the defense of Pensacola } \\
\text { should be commenced as } \\
\text { early as possible, in order } \\
\text { to afford protection to the } \\
\text { Naval Establishment at } \\
\text { that place and to secure to } \\
\text { our ships of war, as well } \\
\text { as to our numerous } \\
\text { merchant vessels for } \\
\text { trading in the Gulf of } \\
\text { Mexico." ("Fortifications } \\
\text { Pensacola Harbor" 1827) }\end{array}$ & & & \\
\hline & $\begin{array}{l}\text { EXPECTATION OF } \\
\text { PERMANENCE: Expect } \\
\text { that engineering projects } \\
\text { such as granite docks can } \\
\text { be permanent ("Report of } \\
\text { the Secretary of the } \\
\text { Navy" 1844) }\end{array}$ & $\begin{array}{l}\text { RESPONSE TO } \\
\text { CHANGE: "The site of } \\
\text { this work has been } \\
\text { undermined by the } \\
\text { action of the sea to such } \\
\text { an extent ... to possess } \\
\text { no value beyond the } \\
\text { materials of which it is } \\
\text { composed." }(\text { Chief of } \\
\text { Engineers } 1874,25)\end{array}$ & & \\
\hline & $\begin{array}{l}\text { RATIONALE FOR } \\
\text { CHANGE: "The net } \\
\text { result of the improvement } \\
\text { has been an increase in } \\
\text { depth of about } 8 \text { feet over } \\
\text { the bar at the mouth of } \\
\text { the harbor, permitting } \\
\text { vessels of deeper draft to } \\
\text { enter." (Board of State } \\
\text { Harbor Commissioners } \\
\text { 1922, 163) }\end{array}$ & $\begin{array}{l}\text { RATIONALE FOR } \\
\text { CHANGE: "You find } \\
\text { that, while there are } \\
\text { substantial hazards to } \\
\text { life and property from } \\
\text { hurricanes, protective } \\
\text { structures are not } \\
\text { economically justified } \\
\text { at the present time." } \\
\text { (Secretary of the Army } \\
\text { 1966) }\end{array}$ & $\begin{array}{l}\text { RESPONSE TO } \\
\text { CHANGE: "Stabilize or } \\
\text { reverse deterioration of } \\
\text { natural and historical } \\
\text { resources consistent with } \\
\text { budgetary constraints and } \\
\text { ecological limitations." } \\
\text { ("Purpose of the National } \\
\text { Seashore" 1973) }\end{array}$ & \\
\hline & $\begin{array}{l}\text { MANAGEMENT } \\
\text { GOAL: "The purpose of } \\
\text { Gulf Islands National } \\
\text { Seashore is to preserve } \\
\text { and interpret its Gulf } \\
\text { Coast barrier island and } \\
\text { bayou ecosystem and its } \\
\text { system of coastal defense } \\
\text { fortifications, while } \\
\text { providing for the public } \\
\text { use and enjoyment of } \\
\text { these resources." (NPS } \\
\text { 2014, 14) }\end{array}$ & $\begin{array}{l}\text { EXPECTATION OF } \\
\text { PERMANENCE: } \\
\text { Protect cultural } \\
\text { resources "unless it is } \\
\text { determined through a } \\
\text { formal process that } \\
\text { disturbance or natural } \\
\text { deterioration is } \\
\text { unavoidable." (NPS } \\
\text { 2014, 40) }\end{array}$ & $\begin{array}{l}\text { RESPONSE TO } \\
\text { CHANGE: “...providing } \\
\text { an alternative means of } \\
\text { accessing the park and } \\
\text { maintaining island access } \\
\text { when the road is rendered } \\
\text { impassable by storm } \\
\text { events or other unfavorable } \\
\text { conditions." (Brown 2015, } \\
47 \text { ) }\end{array}$ & $\begin{array}{l}\text { RATIONALE FOR } \\
\text { CHANGE: } \\
\text { "[restore] the } \\
\text { Mississippi Barrier } \\
\text { Islands as part of a } \\
\text { comprehensive } \\
\text { plan to increase the } \\
\text { resiliency of the } \\
\text { coast to future } \\
\text { storm events." } \\
\text { (U.S. Army Corps } \\
\text { of Engineers } \\
\text { Mobile District } \\
\text { 2016, ii) }\end{array}$ \\
\hline
\end{tabular}

In GUIS, managers perceived change as the daily norm rather than an event or occurrence and this expectation of constant change makes it difficult to detect the 
impacts of climate change. All of the managers at GUIS indicated that ongoing, daily tasks associated with preserving historic structures and the accompanying visitor infrastructure were the biggest challenges in the park. Between managing the daily impacts of salt water, long growing seasons, sand movement causing sinkholes, flooding from rain, and occasional hurricane or storm impacts, managers perceive changes in the environment to be both normal as well as potentially sudden. Managers do not discuss the ongoing maintenance to address these weather patterns as changes but do see the introduction of the ferry system to maintain visitor access to Fort Pickens as a change in the way in which visitors will use the park. Additionally, managers perceive the MsCIP project as a change. The MsCIP project will recreate a system through which the mainland Mississippi shoreline may be more protected from hurricanes; however, due to the dynamic nature of sand in the area, while this project is an artificial fix in the system, there is a possibility that sand could have naturally moved to the locations where it will be placed. Rather than a strict outline of human and environmental change, statements made by managers in GUIS suggest that they view change as a call and response between people and the environment, with the manipulation of shorelines being part of that call and response.

\section{San Francisco Maritime National Historical Park, California}

The San Francisco waterfront is a complex urban system of hardened shoreline and overlapping uses of coastal space, where the ongoing development and changing uses of the waterfront have shaped land-water interface as well as human patterns of fishing, travel, and recreation in the area. The environmental patterns in the Bay Area 
are dominated by the fog and pervasive damp conditions which affect navigation in the Bay and cause manmade structures on the peninsula to weather (Okamoto and Wong 2011; Kemble 1978). Within 20 years of American annexation of San Francisco, the city transitioned from a rural hacienda system to an urban center, and as part of this development, residents began building artificial land in the Bay (Barth 1975). Between along the coast of the San Francisco Bay, immediately landward of Alcatraz Island, the North Beach and Marina districts of San Francisco were once part of a marsh shoreline. When residents began requesting additional waterfront recreational space in the early $20^{\text {th }}$ century, the city eventually added land to the waterfront in order to meet these needs. Today, the filled land along the waterfront is part of San Francisco Maritime National Historical Park (SAFR) which preserves the largest historic fleet of fishing, coastwise transport, and other vessels in the American Pacific and includes various tourist attractions, as well as urban green space, and a commuter thoroughfare, shown in Figure 12.

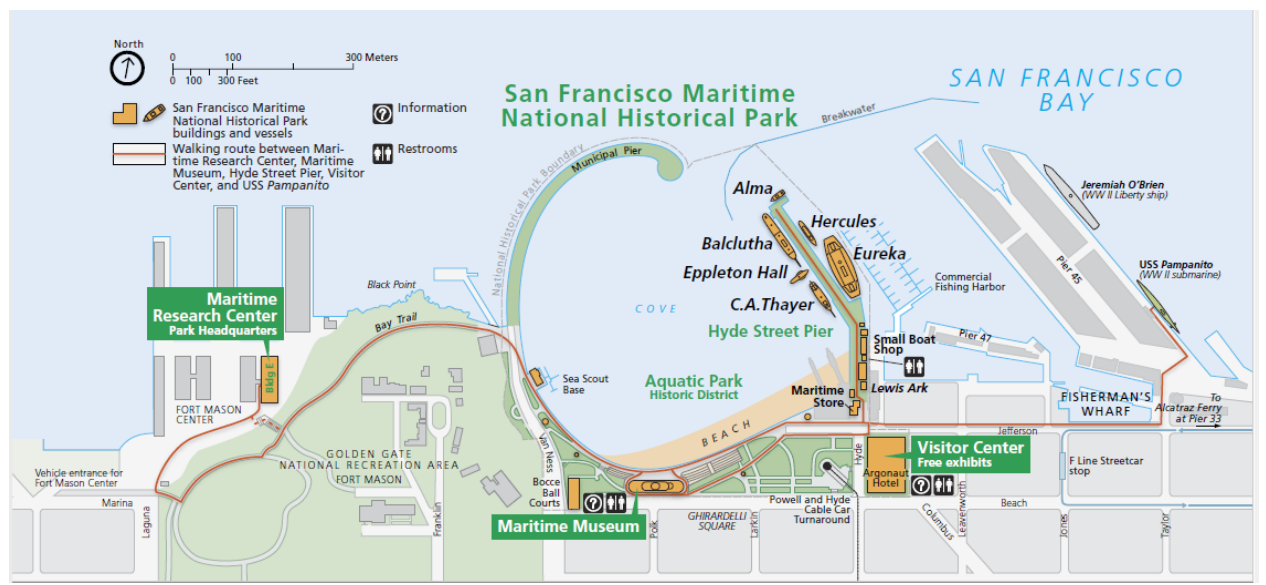

Figure 12. San Francisco Maritime National Historical Park Map.

Overtime, as the needs and uses of the waterfront have changed, managers have established different management goals, expectations of permanence, rationales 
for change, and responses to environmental change in the area, as revealed by both the built and natural environment in the area, as well as the records of managers and observers. As NPS managers at SAFR begin to work with their parent park of Golden Gate National Recreation Area, as well as city managers and numerous other interests, managers are faced with new environmental challenges and conditions that will affect the future management decisions in the area. At SAFR, management goals have changed overtime from managing a fleet of vessels in seaworthy condition, to managing a collection of floating museums that illustrate histories of the Bay. As managers begin to address the impacts of climate change at SAFR, park officials are dependent on urban infrastructure and collaboration on seawall structures and roads and are limited in the amount of space for relocation or other options. While managers expect change in both the natural and built environment, the park will have only one of many voices in the urban planning process.

\section{Building an Imperial City to Claim a Continent, U.S. Army Corps and City of San Francisco, 1854-1928}

When Americans began entering San Francisco in large numbers in the late 1840s, the pace of technological development allowed these settlers to make rapid and massive alterations to the marshes of the San Francisco Peninsula, both directly, and through major modifications of the foothills upstream from the bay. New San Franciscans filled tidal wetlands on the eastern shore of the peninsula to create valuable land in the city. In 1863, the people of San Francisco asked for a commission to manage and regulate the wharves and seawall of the city (Dow 1973). The state 
appointed a Board of State Harbor Commissioners, a three-member group who were to oversee and maintain the waterfront in good repair, undertake dredging efforts, and construct additional pier and wharf facilities as needed. These management efforts focused on expanding commerce in the growing city. Standards for success of the work were based on the continuation and expansion of commerce in the city. In addition to changing in the waterfront line, San Francisco residents worked to import fish species that were more familiar and pleasing to originally east coast palates (Booker 2006). Changes were made to the city's waterfront for commercial purposes and similarly, residents responded to environmental changes such as storms or wave action carrying away fill by repairing and replacing the artificial shoreline.

\section{Providing Urban Green Space, City of San Francisco and National Park Service, 1928-present}

In the 1930s, after years of public requests and campaigns, city officials installed Aquatic Park. When the area became part of NPS in the 1970s, park managers worked to continue the recreational and urban green space goals that founded the park. In order to maintain Aquatic Park and the small, man-made beach, managers instigated environmental change by replacing the sand as needed following loss during storms. This fixation of sand in place, either through the construction of breakwaters or the direct replacement of the sand shows a static management system, focused on retaining a site and structure in place, and responding to winter storms and changes by recreating the site that was in place before. In 1980, a winter storm damaged the Fort Point seawall, eroded the road that runs along the water, and left 12- 
18 inches of water in the fort ("Annual Report of the Golden Gate National Recreation Area, 1980" 1980). The following year, winter storms again affected the seawall and managers noticed undercutting. The maintenance division "restored the area to normal (“Annual Report of the Golden Gate National Recreation Area, 1980” 1980).” Thus, managers attempted to make the uses and features of the landscape permanent on a background of changing conditions.

\section{Overlapping Interests and Waterfront Climate Change, 2009-present}

As managers at SAFR begin to address climate change, their management goals include preserving both resources and access to the piers, trails, and ships in the park. Mangers suggested solutions include understanding decision points, conducting surveys to understand loss, rebuilding structures in accordance with climate change projections, and potentially relocating structures that are at inevitable risk if there is room to put them. However, SAFR managers are dependent on partnerships with the city and state in order to manage the potential future change on the waterfront associated with the rebuilding or repair of the seawall. The seafront between San Francisco’s North Beach and Marina districts, where San Francisco Maritime National Historical Park (SAFR) is located, has been built into the bay overtime. In the park, managers will work with the city to develop next steps and plans for the waterfront. Preservation priorities will need to work with various neighbors and partners in the urban waterfront system.

SAFR is a small park and works closely with Golden Gate National Recreational Area (GOGA) for scientific needs. GOGA was established as an urban 
park and works in partnership with the Golden Gate National Parks Conservancy, a non-profit organization. GOGA was established as an urban green space and as such, focuses on community-based programming (National Park Service 1993). GOGA managers discussed a public process as a part of identifying how to adapt parks for climate change. GOGA received public input on visions for Crissy Field, a low-lying, $20^{\text {th }}$-century constructed recreational space along the Bay, in a future where the area is inundated (Golden Gate National Parks Conservancy 2016). The identity of SAFR as an urban park is be contributing to how climate change approaches are manifesting in the park. Managers are working with urban systems outside of the park to develop preservation priorities and climate change strategies. Similarly, SAFR identifies their role in climate change as one of teaching the public conservation strategies, placing the park in a broader context or a process-based context for cultural knowledge or awareness of climate change. 
Table 10. Management goals, expectations of permanence, rationale for creating change, and response to environmental change overtime in San Francisco's North Beach and Aquatic Park Area.

\begin{tabular}{|c|c|c|c|c|}
\hline \multicolumn{2}{|c|}{$\begin{array}{l}\text { San Francisco Maritime National } \\
\text { Historical Park }\end{array}$} & & & \\
\hline \multirow{4}{*}{ 窎 } & $\begin{array}{l}\text { MANAGEMENT GOAL: } \\
\text { "The acquisition of } \\
\text { California presents } \\
\text { facilities for trade and } \\
\text { intercourse with China } \\
\text { which ought not be } \\
\text { neglected." (Stanton 1851) }\end{array}$ & & & \\
\hline & $\begin{array}{l}\text { RATIONALE FOR } \\
\text { CHANGE: “...the city } \\
\text { council passed an } \\
\text { ordinance to sell the city } \\
\text { slip water-lots - they were } \\
\text { covered by the bay, some } \\
\text { of them to a depth of } 25 \text { - } \\
\text { feet at low tide." ("City } \\
\text { Slip Sale" 1853) }\end{array}$ & $\begin{array}{l}\text { RESPONSE TO } \\
\text { CHANGE: "During the } \\
\text { past year operations } \\
\text { were chiefly confined to } \\
\text { the construction of an } \\
\text { apron in front of the sea- } \\
\text { wall...to prevent the } \\
\text { action of the sea in } \\
\text { washing away the beach } \\
\text { and undermining this } \\
\text { wall." (Chief of } \\
\text { Engineers } 1870,27)\end{array}$ & & \\
\hline & $\begin{array}{l}\text { EXPECTATION OF } \\
\text { PERMANENCE: } \\
\text { "...material changes had } \\
\text { taken place in the line of } \\
\text { high-water mark on the } \\
\text { Bay of San Francisco, } \\
\text { arising from natural } \\
\text { causes, the action of the } \\
\text { winds and waves, and the } \\
\text { accumulation of debris } \\
\text { and sand along the } \\
\text { shores." (Pacheco 1880) }\end{array}$ & $\begin{array}{l}\text { RATIONALE FOR } \\
\text { CHANGE: "However, } \\
\text { removal of drift and its } \\
\text { hazards to navigation, } \\
\text { like maintenance } \\
\text { dredging, is necessary } \\
\text { and must be done to } \\
\text { maintain good port } \\
\text { conditions." (Army } \\
\text { Corps of Engineers } \\
\text { 1948, 21) }\end{array}$ & $\begin{array}{l}\text { EXPECTATION OF } \\
\text { PERMANENCE: “...the } \\
\text { use of filled land } \\
\text { involves substantial } \\
\text { hazard to life and } \\
\text { property when } \\
\text { earthquakes shake the } \\
\text { jelly-like muds of the } \\
\text { Bay." (Protecting } \\
\text { America's Estuaries } \\
\text { 1970, 19) }\end{array}$ & \\
\hline & $\begin{array}{l}\text { MANAGEMENT GOAL: } \\
\text { "preserve and interpret the } \\
\text { history and achievements } \\
\text { of seafaring Americans } \\
\text { and of the Nation's } \\
\text { maritime heritage, } \\
\text { especially on the Pacific } \\
\text { Coast..." (NPS 1997) }\end{array}$ & $\begin{array}{l}\text { RESPONSE TO } \\
\text { CHANGE: "Due to age, } \\
\text { water intrusion, general } \\
\text { weathering, and } \\
\text { exposure to the sea/salt } \\
\text { environment, most of the } \\
\text { amphitheater structure is } \\
\text { in a severely deteriorated } \\
\text { condition, making it } \\
\text { potentially unsafe for } \\
\text { visitors." (National Park } \\
\text { Service 2006, 1) }\end{array}$ & $\begin{array}{l}\text { MANAGEMENT } \\
\text { GOAL: "By seriously } \\
\text { addressing GHG } \\
\text { emissions within the } \\
\text { Park... San Francisco } \\
\text { Maritime National } \\
\text { Historical Park will help } \\
\text { mitigate climate change } \\
\text { far beyond the Park's } \\
\text { boundaries." (National } \\
\text { Park Service 2009, 20) }\end{array}$ & $\begin{array}{l}\text { EXPECTATION OF } \\
\text { PERMANENCE: } \\
\text { "Increases in sea } \\
\text { level and storm } \\
\text { surge render roads, } \\
\text { wharfs, and other } \\
\text { coastal infrastructure } \\
\text { more vulnerable to } \\
\text { substantially } \\
\text { damaging and costly } \\
\text { flooding." (Gonzalez } \\
\text { 2015,2) }\end{array}$ \\
\hline
\end{tabular}

SAFR managers assessed the change in the environment by observing species

changes in the Bay and other shifts in natural phenomena before identifying changes

in the built environment such as nuisance flooding on the pier. From its beginnings as

an "instant city," to ongoing destruction from earthquake and subsequent fires, the 
built nature of San Francisco has repeatedly changed. Similarly, early American settlers imported species to the Bay and the nature of the Bay has changed dramatically overtime from mining runoff, fill, and overfishing. While managers are anticipating climate change at SAFR, much of their management action will be dependent on decisions between the various players in the urban landscape rather than park decisions. Managers indicated a certain amount of powerlessness over the timeline of these projects.

\section{Towards a Framework for Changing Cultural Resource Management Priorities}

The assessment of management documents and perceptions of change in each of these sites overtime shows that, in each site, as national regulations and local uses of coastal spaces have become more complex, managers responsibilities have increased. Rather than managing for a few uses, managers today are responsible for expanded management goals ranging from preservation and tourism to conservation and regulating fisheries. As management goals have become more complex due to more and more varied coastal patterns of use, cultural shifts have affected the rationale for creating change, appropriate responses to coastal volatility, and managers expectations of permanence (Casey 2018, in preparation). By examining each of these criteria at the national level overtime, a pattern emerges.

As former military, industrial, or multi-use sites become cultural or recreational resources, the management requirements change. As the uses of these places changes, the value of the physical structures on the landscape also changes to reflect new priorities. Since the historical period, managers perceptions of the value of 
different environmental components have undergone a transition. Where early managers focused on the use of the natural and built environment, for recreational or other purposes, later managers shifted their focus to a broader system of processes. More recently, the shift in ecological understandings, as evidenced by broader policy movements such as ecosystem-based management, has led managers to focus on system function. The interaction between natural and human has been brought into focus by phenomena such as climate change. Despite a division in NPS between natural and cultural resource management, changes such as the introduction of cultural landscapes as a unit of study and preservation, the updating of the Leopold Report, and Directors Order 100 all reflect a broader approach. More recently, managers are focusing on systems, interactions, and ecological processes, where the function of a process rather than the characteristics of a place have become the goal. For instance, at COLO, a recent study recommends the return to natural coastal processes and at MsCIP, the Army Corps is intentionally recreating portions of the park to contribute to the preservation of the Mississippi coastline.

Overtime, management of the built and natural landscape have focused on commodity and use of the site, where generating change to the natural or built environment was approached in a pragmatic sense. Management efforts focused on the retention of a site or characteristics of that site that were key to the new recreational or educational priorities such as the retention of the 1607 shoreline of Jamestown Island. During this period, management documents use terms including "beach nourishment," "erosion control," and "dune stabilization" to describe management efforts (Pridemore 1981; “Gulf Islands National Seashore Advisory Committee Meeting" 1973). These 
phrases emphasize a natural state that is unacceptable and requires a management intervention. These phrases also suggest an adherence to a standard for success that is based on holding the line of an original form. More recently, enhanced ecological understanding as well as increasingly competitive uses in the coastal environment have led to a transition from place- to process-based management. While processbased management adheres to a standard that differs from how the current system or function presents, the emphasis is on a process rather than on a line. Table 11. outlines this pattern of change based on four drivers of change: management goal, expectation of permanence, rationale for creating change, and responses to coastal change.

Table 11. framework of the transition of management priorities overtime from resource-, useand process-based resource management.

\begin{tabular}{|l|l|l|l|}
\hline Priority & $\begin{array}{l}\text { Use-Based } \\
\text { Management }\end{array}$ & $\begin{array}{l}\text { Place-Based } \\
\text { Management }\end{array}$ & $\begin{array}{l}\text { Process-Based } \\
\text { Management }\end{array}$ \\
\hline Management Goal & Commodity and use & $\begin{array}{l}\text { Place and } \\
\text { Characteristics }\end{array}$ & $\begin{array}{l}\text { Function of site within } \\
\text { the context of a broader } \\
\text { system }\end{array}$ \\
\hline $\begin{array}{l}\text { Rationale for } \\
\text { Creating Change }\end{array}$ & $\begin{array}{l}\text { Managers alter built } \\
\text { and natural } \\
\text { environment as needed }\end{array}$ & $\begin{array}{l}\text { Managers interpret past } \\
\text { environmental change } \\
\text { but not new alterations }\end{array}$ & $\begin{array}{l}\text { Managers respond to } \\
\text { changes in the natural } \\
\text { and built environment }\end{array}$ \\
\hline $\begin{array}{l}\text { Eesponse to Coastal } \\
\text { Storm Surge }\end{array}$ & $\begin{array}{l}\text { Managers repair, refit, } \\
\text { or rebuild, and only } \\
\text { recreate a past model if } \\
\text { it worked }\end{array}$ & $\begin{array}{l}\text { Managers repair in- } \\
\text { kind, may make some } \\
\text { pro-active changes to } \\
\text { structures }\end{array}$ & $\begin{array}{l}\text { Managers harness } \\
\text { natural processes to } \\
\text { address impacts (Ex. }\end{array}$ \\
\hline $\begin{array}{l}\text { Expectation of } \\
\text { Permanence }\end{array}$ & $\begin{array}{l}\text { No expectation of } \\
\text { permanence }\end{array}$ & $\begin{array}{l}\text { Expectation of } \\
\text { engineered permanence }\end{array}$ & $\begin{array}{l}\text { Decision on } \\
\text { permanence }\end{array}$ \\
\hline
\end{tabular}

The nature of the relationship between resource and manager has changed as cultural resources have transitioned from objects or sites of use to objects that are protected for research purposes. As the nature of use of these resources has transitioned, the ways in which the resource can adapt to climate have been confined based on a new perception of the value of the resource. In the face of climate change, NPS is reassessing the value and feasibility of resource preservation. However, 
changing scientific understandings of human-ecological systems are contributing to this value shift. While Director Jarvis identified climate change as the newest and greatest threat to park resources, and climate change has become a focus at the national and regional levels of the park service, climate change may not be the biggest driver or priority within a park. Managers at GUIS are more concerned about daily maintenance and changes in the barrier island system. Managers at SAFR will need to work with neighbor and partner agencies on climate change measures on the built shoreline.

\section{The Role of Place and Context in Climate Change Perceptions and Actions}

As park managers work to address climate change in their parks, the different park priorities and locales are causing this shifting management trend to manifest differently based on both environmental factors, the types of resources the park was created to preserve, and context dependent factors such as champions of causes and park manager priorities. At COLO, the slow pace of erosion and the longstanding interest in archaeological sites at the location is leading managers to focus on the potential climate change loss of these sites and research potential. At GUIS, the daily and seasonal maintenance required on a shifting barrier island system is obscuring the impacts of climate change; however, in a park focused on recreation, managers are most concerned with maintaining safety and access to the forts and beaches. At SAFR, managers identify many biological changes in the bay, as well as erosion and nuisance flooding on land as climate change affects; however, the existence of many features of the park is tied to the decisions of park partners on jointly owned and managed 
infrastructure including seawalls and piers. At each park location, managers are concerned about the daily changes and risks to resources from weathering and other forces. However, the type of environmental change in the local environment affects managers identification of risk to the cultural resources in their park. The results of this study are context dependent and should be considered illustrative rather than transferable to other locations. As illustrative examples, some of the themes derived from either the features of the location: COLO as a sediment river system, GUIS as a barrier island system, and SAFR as an urban waterfront, or the value assigned to the historical resources in the park: COLO for archaeological sites, GUIS for recreational use, and SAFR for urban green space, may be applicable to other sites.

\section{Management Legacies and Climate Change Actions}

Examining the management goals, ideas of permanence, rationale for change, and response to environmental change overtime reveals that the current approach to management is culturally conditioned by modern understanding of cultural resources and landscapes. In the last 40 years, the national focus on biological and ecological understanding has influenced park management and parks began managing the restoration of natural systems. Starting with the inventory and monitoring programs of the 1980s, managers began to focus on the components of site as the foundational blocks that defined the resources. Aided by mapping technologies, this new method of management led to both a focus on components in addition to the whole. The approach to management that involves inventories and the identification of individual sites and artifacts identifies climate change risk as the potential for harm or destruction to 
historic structures, archaeological sites, and cultural landscapes. As NPS managers work to address the impacts of climate change on the cultural resources in their parks, federal level guidance reflects national priorities of addressing climate change within the existing systems of management in order to address the timeliness of the threat by making "tough choices" about which sites to record and/or allow to deteriorate, versus which sites to engineer protection or resilience measures. This idea reinforces the idea that the components of the system are at risk rather than the use and meaning of place.

This current approach to management does not protect or facilitate the adjustment to losses from climate change nor does it necessarily imply an adaptive management structure given coastal erosion and inundation. NPS lays out seven management strategies for cultural resources, ranging from allowing the resources to succumb to the environment to actively managing and improving the condition of the resource (Rockman et al. 2016; Beavers, Babson, and Schupp 2016). One of the strategies recommends managing the changing resource condition. This adaptive form of management to supervise the transition of the structure possibly to an underwater site or through a process of ruination may require NPS to partner with other agencies in places where NPS does not own submerged lands. If the result of a tough choice is an adaptive management scheme as resources transition from coastal to underwater sites, this tough choice may represent a more adaptive management practice.

\section{Conclusion}

The mission of The U.S. National Park Service is to "preserve unimpaired the natural and cultural resources and values of the National Park System for the 
enjoyment, education, and inspiration of this and future generations (NPS 1916).” While the mission of NPS has remained true to its form from 1916 when the organization was founded, the management of the park service has undergone transitions since its inception. As these sites and structures transition from places of military, industrial, or residential uses to places that act as primary sources for research, historical interpretation, and recreation, the legal regimes that govern these places are changing. By comparing the change in perspectives at these three sites overtime, a pattern of shifting values in landscape management emerges. Akin to the management shift in natural resources from species or sectoral management to ecosystem-based managed, the management of cultural resources overtime has transitioned from a focus on the use of the site or structure to the preservation of a place, to a broader look at sites and structures for their contribution to a system. 


\section{CHAPTER 7: CONCLUSION}

Focused on climate change adaptation for cultural resources, the sum of this study this study took distinct temporal and methodological approaches to the same topic: interviews with key informants illuminated barriers faced by managers in adapting cultural resource policies and practices to changing climate conditions and cultural landscape assessments of the parks revealed long-term patterns of change that influence cultural resource policies and practices. By taking a historical approach, this work exposed possible roots of adaptation barriers, as well as deeper-seated environmental perceptions and path-dependencies, which may continue flavor current climate change approaches in these settings. These chapters also demonstrate patterns and outcomes of environmental response and alteration overtime and contributes to a more complete understanding of the complex transformation of NPS management overtime and continuing with the advent of climate change. The remaining section highlights emergent themes from the outcomes of each case study, drawing attention to parallels between cases, observations on this methodological approach that could be applied in other places, recommendations for NPS and other cultural resource management agencies moving forward with climate change adaptation plans to preserve cultural resources from this study. Finally, this chapter concludes with a discussion of areas that could be fruitful for further research using a historical research perspective.

\section{Climate Change Threatens Not Only Place but American Identity}

To address the climate change impacts on cultural heritage at this site, there is far more to discuss than rising sea levels and storm surge: climate change and shoreline 
erosion is challenging American identity, both through the destruction of cultural resources that serve as primary sources of data about the past, but also by threatening the ability of federal managers to protect these resources. The direct impacts of climate change on cultural resources may affect the ability of archaeologists and others to use these resources as primary sources of data. As archaeological sites are inundated, they may instead become underwater archaeological properties or may be damaged by storm surge.

Throughout history, federal managers have engineered responses to prevent coastal erosion in these areas, showing a dominance over the ongoing erosion at the site, and holding back both nature and development. Climate change threatens the engineering supremacy of Americans over nature. And in a space with significance and meaning, climate change challenges a legacy of American supremacy on the coastline and the ability to retain and control an American history. While managers can continue to engineer shorelines and sand in these areas, sea level rise represents a different challenge and threatens the ability of managers to retain these long-engineered spaces. Climate change challenges national identity in these places, and the American relationship with the coastal environment, in addition to the physical remains of the resources.

\section{Managing Expectations of Permanence in Resource Use and Environmental}

\section{Condition}

In the face of erosion, hurricanes, and other changes, managers have engineered shorelines and spaces to maintain the current management priorities. Despite understanding the motion or change in these spaces, managers expected to see a stable 
state. NPS documentation on climate change aims to provide park managers with science on climate change; however, this historic trajectory suggests that seeing or understanding the science of environmental change does not necessarily motivate action if the changes directly conflict with management priorities. While managers have sought permanence overtime, the shorelines, structures, species, and states of the park they have worked to protect have changed overtime as national and NPS priorities have shifted. In each of the three sites, managers' expectations of environmental permanence are pervasive through time. As federal management priorities change, managers' expectations of what should be made permanent similarly shift, but these three studies show that overtime, managers have anticipated or engineered a stable environment despite observation and understanding of the environmental change overtime.

\section{Lost Resources Do Not Always Lose All Value}

At each of the three case study sites, cultural resources have been lost overtime. While some of these sites have retained value through their archaeological remains and the ability to study these remains, this non-renewable use of cultural resources is threatened by climate change. Sites can be interpreted for visitors without physical remains. Managers indicated that interpretation of cultural resources without corresponding physical remains is part of the method of interpretation staff employ. Updating and changing technologies such as smart phone applications allow managers to convey information about cultural resources that are no longer present on the landscape in visual, creative, and interactive ways. Climate change may add to the already 
numerous challenges of historic preservation, may further compound human relationships with the environment, and may push overlapping uses into direct conflict.

As the use of national park spaces transitioned from commercial, military, or another purpose to emphasize the recreational and educational values of the space, the sites and structures inherited by NPS were often damaged or already in ruins when they entered the park system. However, this status did not necessarily detract from the value of the site. The changing priority in site use allows a ruined site that does not meet military or historic preservation guidelines to retain significance and use as a part of the recreational landscape. The ability of cultural resources to retain value outside of the requirements for historic preservation may be an important consideration for climate change adaptation. While sites may have historic significance, if their use and significance is derived from recreational uses, the site condition may not be a paramount concern for preservation resources.

Preservation of cultural sites, structures, and landscapes in the face of climate change may require managers and others to accept change as part of these landscapes, both as part of the story they tell, and as the condition in which things are maintained. Ruination has always been a part of the landscape. Managers and other's perceptions of the landscape have long included and understood the natural weathering and decay of the built environment. As climate change increases the intensity of some of these weathering factors or changes the environmental specifications to which sites were originally built, the natural weathering and decay may be affected. In addition to tough choices as to which sites to invest the most time and attention into, notions of what preservation means may need to change. Structures with damage and little integrity may need to be 
considered for their past importance rather than being rejected for their condition as this condition may become more commonplace.

\section{Prioritization is More than Just Sitting Down and Making "Tough Choices"}

Prioritizing cultural resources for preservation in the face of climate change is a barrier to climate change adaptation. After assessing the vulnerability of cultural resources to climate change projections, prioritizing resources and adaptation plans is the next step in working towards adapting the site for climate change (Glick, Stein, and Edelson 2011). However, this presents three problems: there is little guidance on how to prioritize resources, the idea of sitting down and making "tough choices" suggests that all of the required information for prioritization has already been gathered within the existing system, and "tough choices" is at odds with ideas of adaptive management based on an increasingly complex set of priorities which may also be changing alongside climate change.

Tough choices are tough for a variety of reasons, one of which is that there is not any precedent for making those decisions. Former military and commercial use regimes in these three sites had identifiable and mostly non-conflicting goals that prescribed management actions. Recreational sites initially had identifiable goals; however, developments in the fields of historic preservation and archaeology, as well as a growing American interest in preserving objects from the past altered and added to the goals of the management of federal spaces. The cultural resources in these areas as represented by the archaeological sites, historic structures, cultural landscapes, and ethnographic and museum collections associated with the area added to the preservation responsibility of 
park managers. In 2011, Patrick Gonzalez, principal climate change scientist of NPS suggested that "areas of unique ecological or cultural value may continue to merit high priority," and suggests that locations should be considered for their uniqueness and vulnerability and managed accordingly. In their 2010 comparison of climate change adaptation literature across NPS, the U.S. Forest Service, and the U.S. Fish and Wildlife Service, Delach and Matson found that NPS plans to work to develop prioritization scales with stakeholders, using scientific assessment, policy, and management tools to inform these decisions. Cultural Resource Climate Change Strategy published in 2016 notes that guidance on prioritization is forthcoming and that the prioritization of resources at each site will remain site specific, subjective, and rooted in current park priorities.

The process of selecting sites for preservation in the face of climate change will require selecting and using modern values to retain sites that are currently considered a priority. This process has taken place throughout history as any management of cultural resources requires selection and culling of which resources to protect, showcase, and interpret (Ashworth 2013; Lowenthal 2015). The political process of selecting which remains at a given site tell the most important story at that site has taken place before, with the designation of park sites and the creation of enabling legislation that identifies what Congress, as advised by park supporters, deems the most important features. As federal managers and research partners begin to work through the process of assessing climate change vulnerability of cultural resources and planning for the adaptation of these resources, understanding the goals of the park may be important in outlining adaptation actions. 
Part of the prioritization challenge is that the sites that are considered to be of national value have changed overtime. The idea of "tough choices" suggests that all of the potential sites for preservation are being considered and the current criteria for site significance and integrity will remain applicable in a reality of climate change. As managers and partners seek to address climate change vulnerabilities, enabling legislation that does not represent current priorities may affect manager's ability to prioritize resources for protection in the face of climate change. If NHLs get the most attention, the first step to prioritization may not be making 'tough choices' but may instead be revising the standards that guide these choices to make sure they accurately represent the best available archaeological and historical evidence and modern stakeholder priorities.

In a 1976 review of NPS designation criteria, the Afro-American Bicentennial Corporation found that the criteria are heavily Euro-centric (The Afro-American Bicentennial Corporation 1973). The Corporation recommended that the history of ethnic minorities is part of the history of the United States and as such, the history of minority groups needs to be considered in all of the military, diplomacy, political and other criteria of American history. The designation of sites including Stonewall National Monument, Belmont-Paul Women's Equality National Monument, Chares Young Buffalo Soldiers National Monument, Pullman National Monument, Cesar A. Chavez National Monument, Birmingham Civil Rights National Monument, Freedom Riders National Monument, Reconstruction Era National Monument, and Harriet Tubman National Historical Park Monuments show an interest in an American history that includes nonwhites, women, industrial history, slavery, LGBTQ, Civil Rights movements, and others (Crosson 2017). 
Although inclusive historical narratives are constantly changing and improving, a subsequent review found that the park service has improved representation of AfricanAmerican sites; however, a challenge of improving the representative nature of cultural resources in a changing climate comes from the bias in historic preservation towards sites that have higher material integrity. Slave homes or other constructions that were built with organic materials and not prioritized for preservation may not meet the preservation criteria that more expensive structures can meet. This systemic bias may be continued or compounded by climate change impacts on cultural resources (Mahoney 2015; Morgan et al. 2016). Archaeological sites may contain the only representations of people who are not recorded in the historical record and this possibility should be considered in cultural resource and climate change prioritization (Mahoney 2015).

The goal of including stakeholder priorities is to ensure a representative history. However, park managers discussed that stakeholders may belong to interest groups that focus on one historical period, form of construction, or group of people. For instance, Civil War societies may emphasize the history of this period. And charismatic structures like lighthouses may receive more support than buried archaeological deposits or a hidden or lesser known resource. As the park service reaches out to stakeholders to identify preservation priorities of cultural resources in the face of climate change, historically marginalized or underrepresented groups may have less of a voice in the conversation (Adger 2003). This potential for the exclusion of certain voices may lead to the loss or exclusion of certain storylines or resources as a part of tangible cultural heritage. In addition to diversifying the mechanism through which stakeholders can provide feedback and making these exchanges as accessible as possible, as the park 
service seeks public input, priority setting procedures may also include review by experts who may be more informed on the variety of time periods, constructions, and people represented by the cultural resources at different sites.

Finally, the idea of "tough choices" suggests a single management decision, rather than ongoing adaptive management given changing climate conditions and resource circumstances. Some managers indicated they would prioritize the most vulnerable sites, while others the least vulnerable sites with the best change of maintaining their integrity despite climate change. Some managers mentioned Historic American Building Survey documentation as a way to preserve records of structures that may be lost, while others argued that the mitigation or removal of sites would affect the value as the context and the ability to ask certain research questions in the future may be lost. When asked about how prioritization would take place, almost all managers mentioned that NHLs are maintained to a higher standard and would receive the most attention. However, rather than making a uniform decision, managers and management plans could work to consider case-by-case resource conditions, park interpretive needs, and changing research questions rather than making tough choices based on existing information.

\section{Addressing Barriers to Adaptive Management of Cultural Resources Given Climate}

\section{Change}

While this study revealed that the interpretive and research uses of resources may require different management regimes, new and burgeoning technologies provide novel ways to interpret sites, structures and landscapes. However, archaeological sites and cultural landscapes are non-renewable, unique resources that lose value if destroyed. New 
technological possibilities, as well as traditional interpretive measures, may allow managers to address just one set of values as they make climate change decisions. Understanding these barriers specific to cultural resources may help NPS managers tailor or prepare ongoing vulnerability assessment or other management procedures for the specific needs of cultural resource management in the face of climate change.

Conceptual barriers to the climate change adaptation of cultural resources present different of challenges. If managers cannot distinguish climate change from ongoing effects of weathering, this may hamper management action for a longer-term impact or problem. Especially for non-living cultural resources which may visibly naturally weather and degrade overtime, managers expect to see change. However, if each instance of change is seen as standard and maintenance regimes are not adjusted, incremental change may lead to complete deterioration more quickly than anticipated. Although some managers identified which cultural resources they found most vulnerable, these vulnerabilities did not uniformly indicate the significance or priority of the resource within current management schemes. While this study illuminated these modern barriers to climate change adaptation, by examining how change has been managed overtime in each of these three site locations, this research illuminated a longer history of these conceptual barriers. The longer history of the management of change in each of these locations both informs these barriers to current action and illuminates additional ongoing management patterns that relate to climate change management in NPS.

\section{Historical Perspectives on Cultural Resources}


Scholars have called for the inclusion of historical perspectives, such as the empirical studies in this research, in climate change adaptation conversations critiquing approaches to the topic by looking at factors like barriers to adaptation, also seen in this research, as ahistorical (Adamson, Hannaford, and Rohland 2018). However, a reciprocal critique of historical research is that this research operates on a slower time table than other fields (Adamson, Hannaford, and Rohland 2018) and the resulting information may be difficult to translate or apply in policy situations (Morin 2017). Through the process of conducting this research, I concede both points. However, like the authors cited in the previous sentence, I believe despite these difficulties, the perspective employed in this work and the resulting conclusions are of value and importance in the climate change adaptation conversation.

This research revealed an American habit of modifying a shoreline and location rather than relocating to a more suitable site. More than just one amongst many choices, this habit has become codified overtime through organizations such as the San Francisco Board of State Harbor Commissioners. Although priorities have changed overtime, managers are still reconciling permanence of features on impermanent landscapes. And these patterns may impact the adaptation options that managers and others identify and consider when addressing climate change. Similarly, past priorities as to which histories to represent have been codified in park management guidelines overtime. As managers work to address change, reconsidering these patterns to determine what additional values the landscape may represent and how these values can be adapted may be an important early step. These findings result directly from the historical approach. And in an attempt to address the critique that historical research is difficult to apply, I provide 
recommendations for moving forward with climate change adaptation management actions for cultural resources; however, these recommendations may also be applicable in other climate change adaptation situations:

1. Rethink management structures to prioritize the goals of management over the conditions of the resource.

2. Gather broad input including scholarly and tribal expertise and public opinion as to what to protect given projected climate change impacts.

3. Explicitly document the process of prioritization for cultural resources.

4. Interpret climate change as a continuous part of the American coastline and link patterns of industrial and physical change to this history.

\section{Future Research}

In considering the tangible cultural heritage that remains along American coastlines, there are many types of investigations that could contribute to better understanding the impacts of climate change on these sites. For the purposes of this study, I focused on the perspectives of federal managers. However, federal managers are increasingly engaging with tribal, state and local governments, non-profit organizations, research institutions, individual stakeholders, local area residents and others to guide park decision-making activities. Additionally, parks, especially urban parks like San Francisco Maritime NHP, are working outside established boundaries to identify community priorities and urban planning for the waterfront. Future research may look at community views of coastal climate volatility including storm surge, coastal flooding, coastal erosion, and sea level rise overtime to conceptualize how residents have and continue to frame coastal climate change, especially with regards to cultural sites and structures. Future research may compare the perspectives of the local managers, state managers, 
commercial communities, or residents with those of federal managers to determine whether there is agreement or divergence in perceptions of change.

This research revealed that American managers have applied policies to the coupled human-natural coastal environment for hundreds of years. While this study examined the impacts of these policies on the environment, future research could examine the outcomes of past policy decisions to determine how effective these policies were in terms of resource protection or to determine how these policies continue to impact management decisions. Additional case study sites of similar or divergent types to the three types identified here (barrier island, urban coastline, and sediment river system) could contribute to broader understandings of context-dependent features of management, or alternately, indicate which features diverge between sites despite similar coastal morphologies and features.

This study answered a multi-disciplinary call for a historical and social-science examination of patterns of environmental change. Cultural resources represent the long tenure of humans on the landscape, and by examining these resources in the modern context, and the cultural interactions with the landscape overtime, this study has revealed that, while climate change may represent a set of environmental circumstances distinct from what managers have addressed in historical memory, the management patterns of historical memory are influencing management actions along the shore today. Management priorities have changed overtime, but the approach to engineering the shoreline have remained similar in a local context. And while managers and others anticipate and understand change on a daily scale, planning for this change on a longerterm scale, when various other factors in the process including management priorities, 
technologies, administrative or institutional priorities, are changing alongside climate, the appropriate set of questions may become much different in the face of climate change. 


\section{APPENDIX}

\section{Appendix A. Interview Questionnaire}

Date:

Case Site:

Participant Number:

Additional interviewer information:

I will ask questions with open-ended responses. The questions will be loosely divided into four sections: climate change impacts, management, and cultural resource, climate change management moving forward, and a section seeking feedback on the interview and research. If at any point you would like to stop the interview, you are welcome to indicate this to me.

\section{Demographic Information}

Job title:

Educational Background:

Years with the National Park Service:

Years at current park:

Parks where you have been employed:

\section{Climate Change and the Cultural Resources at Your National Park}

During your time with NPS, what changes have you noticed in the condition of the cultural resources at your park?

How have these resources been impacted by coastal weather and climate conditions including coastal erosion, sea level rise, storm surge, and flooding?

Have the historic structures, landscapes, or sites at this park required extensive or out-ofthe-ordinary maintenance for climate or weather-related factors? 
In your opinion, what poses the biggest risk to the condition of cultural resources in the park?

\section{$\underline{\text { Historical Perspective and Site Interpretation }}$}

Are certain themes in your park being affected more than others due to climate change?

- i.e. Native American or black history sites on the coast

- what, if anything, is the park able or required to do to protect different historic themes?

Are there examples of historical stories or themes in your park that are interpreted for visitors without the presence of any physical artifacts or historic landscapes?

- Is this method effective? Do visitors like these stories?

Does your park interpret historical climate or climate change for visitors?

- Any panels or plaques? Ranger talks?

Is there a place in your park for historic environmental perspectives in site interpretation?

- For instance, if past communities in the area would have built more flexible infrastructure or moved inland, would this type of alteration be considered in park adaptation planning?

\section{The Decision-making Process for Cultural Resources and Climate Change Impacts}

Are there any studies by the NPS or others on climate change and cultural resources going on in your park right now? Or have any studies been conducted recently?

- Have you seen the results of any studies? Do you think any of these results could be applied to park policies?

If you were asked to prioritize resources to protect from climate change, how would you set these priorities? What would most heavily influence those decisions?

- Internal factors: Historic significance? Rarity?

- External factors: Cost? Visitor interest? Superintendent or partner priorities?

\section{Follow-up}

Given the topic at hand, is there anything else you would like to point out or anything that you think was missing from our conversation? 


\section{REFERENCES}

A Joint Resolution of Congress, Providing for the Erection of a Monument at Yorktown, VA. Commemorative of the Surrender of Lord Cornwallis. 1883. Washington, D.C.

"A Quarter of a Century." 1875. Carton 18, Folder 1, San Francisco, Bancroft Reference Notes for California, [ca. 1870-1890]. Bancroft Library, University of California, Berkeley, California.

Abbott, Carl. 1977. "Norfolk in the New Century: The Jamestown Exposition and Urban Boosterism." The Virginia Magazine of History and Biography 85 (1): 86-96.

Abbott, Stanley W. 1953. "Hurricane Damage at Colonial." Record Group 79, Records of the National Park Service, Administrative Files, 1949-1971, Box 638. National Archives, College Park, Maryland.

Adams. 1938a. Cape Henry Memorial, Fort Story, Virginia. Washington, D.C. 1938b. Colonial National Historical Park, VA. Washington, D.C.

Adams, Stephen. 2001. The Best and Worst Country in the World: Perspectives on the Early Virginia Landscape. Charlottesville, Virginia: University Press of Virginia.

Adamson, George C.D., Matthew J. Hannaford, and Eleanora Rohland. 2018. "ReThinking the Present: The Role of a Historical Focus in Climate Change Adaptation Research.” Global Environmental Change 48: 195-205.

Adger, W. Neil. 2003. "Social Capital, Collective Action, and Adaptation to Climate Change." Economic Geography 79 (4): 387-405.

Adger, W. Neil, Jon Barnett, Katrina Brown, Nadine Marshall, and Karen O’Brien. 2012. "Cultural Dimensions of Climate Change Impacts and Adaptation." Nature Climate Change 3: 112-17.

Advisory Board on National Parks, Historic Sites, Buildings and Monuments. 1966. "Summary Minutes of the 54th Meeting Advisory Board on National Parks, Historic Sites, Buildings and Monuments." Record Group 79 Records of the National Park Service, General Correspondence of the Asst Director for Design \& Construction, 1965-1968, Box 1. National Archives, College Park, Maryland.

Albright, Horace. 1930. "For Release Tuesday Morning Newspapers." National Press. Record Group 79 Records of the National Park Service, Classified Files, 19271931, Box 53. National Archives, College Park, Maryland.

_. 1931. "Albright to Toms." Record Group 79 Records of the National Park Service, Classified Files, 1927-1931, Box 53. National Archives, College Park, Maryland.

Amberg, S., K. Kilkus, S. Gardener, J.E. Gross, M. Wood, and B. Drazkowski. 2012. "Badlands National Park: Climate Change Vulnerability Assessment." Natural 
Resource Report NPS/BADL/NRR--2012/505. Fort Collins, Colorado: National Park Service.

Amundsen, Helene, Frode Berglund, and Hege Westskog. 2010. "Overcoming Barriers to Climate Change Adaptation--A Question of Multi-Level Governance?"

Environment and Planning C: Government and Policy 28: 276-89. https://doi.org/10.1068/c0941.

Andrews, Richard N.L. 1999. Managing the Environment, Managing Ourselves: A History of American Environmental Policy. New Haven, Connecticut: Yale University Press.

Annual Report of the Chief of Engineers, United States Army, to the Secretary of War for the Year 1881, Part I. 1881. Washington, D.C.

Annual Report of the Chief of Engineers, United States Army, to the Secretary of War for the Year 1882, Part I. 1882. Washington, D.C.

Annual Report of the Chief of Engineers, United States Army, to the Secretary of War for the Year 1887, Part II. 1887. Washington, D.C.

Annual Report of the Chief of Engineers, United States Army, to the Secretary of War for the Year 1890, Part I. 1890. Washington, D.C.

“Annual Report of the Golden Gate National Recreation Area, 1980." 1980. Record Group 79 Records of the National Park Service, Superintendent's Annual Narrative Reports, 1980-2001, Box 25. National Archives, College Park, Maryland.

“Annual Report of the Golden Gate National Recreation Area, 1983." 1984. Record Group 79 Records of the National Park Service, Superintendent's Annual Narrative Reports, 1980-2001, Box 25. National Archives, College Park, Maryland.

"Annual Report of the Southeast Region Superintendent for Gulf Islands National Seashore." 1981. Record Group 79 Records of the National Park Service, Superintendent's Annual Narrative Reports, 1980-2001, Box 28. National Archives, College Park, Maryland.

Archie, Kelli M., Lisa Dilling, Jana B. Milford, and Fred C. Pampel. 2012. "Climate Change and Western Public Lands: A Survey of U.S. Federal Land Managers on the Status of Adaptation Efforts." Ecology and Society 17 (4): 20. https://doi.org/10.5751/ES-05187-170420.

"Arguello to Berica." 1797. Carton 16, Folder 14, San Francisco, Bancroft Reference Notes for California, [ca. 1870-1890]. Bancroft Library, University of California, Berkeley, California.

Army Corps. 1933. The Ports of San Francisco, Oakland, Berkeley, Richmond, Upper San Francisco Bay, Santa Cruz, and Monterey California. Washington, D.C.: United States Government Printing Office. 
1948. "Review of Reports, San Francisco Harbor and Bay, California." Record Group 79 Records of the National Park Service, Records Concerning Water Matters, 1936-1949, Box 51. National Archives, College Park, Maryland. . 1975. "Breakwater Study for Light Draft Navigation.” Army Corps of Engineers. San Francisco Maritime Research Library.

. 1977. "Environmental Statement, Fisherman's Wharf, San Francisco Harbor, California." San Francisco, California. San Francisco Maritime Research Library.

_ 2002. "Shoreline Management Plan Colonial National Historical Park Jamestown Island, Virginia.” Norfolk, Virginia: Army Corps of Engineers. . 2013. "York River Shoreline Stabilization, Colonial Parkway, Yorktown, Virginia." Geotechnical Report. Norfolk, Virginia: U.S. Army Corps of Engineers.

- 2016. "Mississippi Coastal Improvements Program (McCIP) Comprehensive Barrier Island Restoration Hancock, Harrison, and Jackson Counties, Mississippi: Final Supplemental Environmental Impact Statement.” Mobile, Alabama: Army Corps of Engineers.

Arsenault, Raymond. 2005. "The Public Storm: Hurricanes and the State in TwentiethCentury America." In Paradise Lost?: The Environmental History of Florida, 201-32. Gainesville, Florida: University Press of Florida.

Ashworth, Gregory, and Peter Larkham. 2013. Building a New Heritage: Tourism, Culture and Identity in the New Europe. New York City, New York: Routeledge.

Assistant Secretary of the Army. 1983. San Francisco Harbor, California: Fisherman's Wharf Area. Washington, D.C.

Attride-Stirling, Jennifer. 2001. "Thematic Networks: An Analytical Tool for Qualitative Research.” Qualitative Research 1 (3): 385-405.

Axelrod, Lawrence J., Timothy Mcdaniels, and Paul Slovic. 1999. "Perceptions of Ecological Risk from Natural Hazards.” Journal of Risk Research 2 (1): 31-53. https://doi.org/10.1080/136698799376970.

Babbie, Earl. 2013. The Practice of Social Research. 13th ed. Belmont, California: Wadsworth Cengage Learning.

Balbach, Harold E., and William D. Goran. 2011. "The Military Landscape: Why US Military Installations Are Located Where They Are.” ERDC/CERL TR-11-7. Washington, D.C.: U.S. Army Corps of Engineers.

Baron, Jill S., Lance Gunderson, Craig D. Allen, Erica Fleishman, Donald McKenzie, Laura A. Meyerson, Jill Oropeza, and Nate Stephenson. 2009. "Options for National Parks and Reserves for Adapting to Climate Change." Environmental Management 44 (December): 1033. 
Bassett, Hayden F. 2016. "The Effects of Sea Level Rise on the Archaeological Resources of Jamestown Island: A LiDAR and Ground-Truthing Assessment." Colonial National Historical Park: National Park Service.

Bassett, Thomas J., and Charles Fogelman. 2013. "Deja vu or Something New?: The Adaptation Concept in the Climate Change Literature." Geoforum 48: 42-53.

Beale. 1880. Light-House on Bell's Rock. Washington, D.C.

Beavers, Rebecca L., Amanda L. Babson, and Courtney A. Schupp. 2016. "Coastal Adaptation Strategies Handbook.” NPS 999/134090. Washington, D.C.: National Park Service.

Beechey, Frederick William. 1831. Narrative of a Voyage to the Pacific and Beering's Strait, to Co-Operate with the Polar Expeditions: Performed in His Majesty's Ship Blossom, under the Command of Captain F.W. Beechey in the Years 1825, 26, 27, 28. London: H. Colburn and R. Bentley.

Beverly, Robert. 1962. "Virginia." In The Colonial Image: Origins of American Culture, edited by John C. Miller and Louis B. Wright, 293-309. New York City, New York: George Braziller.

Bickerstaff, Karen. 2004. "Risk Perception Research: Socio-Cultural Perspectives on the Public Experience of Air Pollution.” Environment International 30 (6): 827-40.

Bierbaum, Rosina, Joel B. Smith, Arthur Lee, Maria Blair, Lynne Carter, Stuart Chapin III, Paul Fleming, et al. 2013. "A Comprehensive Review of Climate Adaptation in the United States: More than before, but Less than Needed." Mitigation and Adaptation Strategies for Global Change 18 (3): 361-406.

Bird, Elizabeth Ann R. 1987. "The Social Construction of Nature: Theoretical Approaches to the History of Environmental Problems." Environmental Review 11 (4): 255-64.

Blake, Jane. 2000. “On Defining the Cultural Heritage.” International and Comparative Law Quarterly 49 (1): 61-85.

Bland. 1926. A Bill to Establish a National Military Park at the Battle Field of Yorktown.

Blanton, Dennis B. 2003. "The Weather Is Fine, Wish You Were Here, Because I'm the Last One Alive: 'Learning' the Environment in the English New World Colonies." In Colonization of Unfamiliar Landscapes: The Archaeology of Adaptation, 190-200. London: Routledge.

. 2013. "The Factors of Climate and Weather in Sixteenth-Century La Florida." In Native and Spanish New Worlds: Sixteenth-Century Entradas in the American Southwest and Southeast, edited by Clay Mathers, Jeffrey M. Mitchem, and Charles M. Haecker, 99-120. Tucson, Arizona: University of Arizona Press.

Bliss' Quarterly. 1897a. "Pensacola and It's Environs," January 1897. Individual Files. University of West Florida Archive and West Florida History Center. 
. 1897b. "The Port of Pensacola...from the Mobile "El Commercial Americano,", January 1897. Individual Files. University of West Florida Archive and West Florida History Center.

Board of State Harbor Commissioners. 1922. "Specifications for Furnishing Materials and Constructing the Substructure for the China Basin Terminal.” William W. Helbush Papers, Folder 1. San Francisco Maritime Research Library.

Boer, Joop de, J. Arjan Wardekker, and Jeroen van der Sluijs. 2010. "Frame-Based Guide to Situated Decision-Making on Climate Change." Global Environmental Change 20 (3): 502-10.

Booker, Matthew Morris. 2013. Down by the Bay: San Francisco’s History Between the Tides. Berkeley, California: University of California Press.

Booker, Matthew Morse. 2006. "Oyster Growers and Oyster Pirates in San Francisco Bay.” Pacific Historical Review 75 (1): 63-88.

Bostrom, Anne, and Daniel Lashof. 2007. "Weather It's Climate Change?" In Creating a Climate for Change: Communicating Climate Change and Facilitating Social Change, 1-30. Cambridge, United Kingdom: Cambridge University Press.

Breen, T.H., and Stephen Innes. 2005. "Myne Own Ground": Race and Freedom on Virginia's Eastern Shore, 1640-1676. 25th Anniversary Edition. New York City, New York: Oxford University Press.

Brimblecombe, P., C.M. Grossi, and I. Harris. 2006. "Climate Change Critical to Cultural Heritage." In Proceedings of the International Conference on Heritage, Weather and Conservation. Madrid, Spain: Taylor and Francis.

Brimblecombe, Peter. 2014. "Refining Climate Change Threats to Heritage." Journal of the Institute of Conservation 37 (2): 85-93.

https://doi.org/10.1080/19455224.2014.916226.

Bristow. 1912. Right of Way Across Fort Mason Military Reservation, California. Washington, D.C.

Brown, Dan. 2015. "Case Study 19: Establishing Alternative Transportation to Fort Pickens to Supplement Vulnerable Road Access, Gulf Islands National Seashore, Florida." In Coastal Adaptation Strategies: Case Studies, 46-47. National Park Service Report, NPS 99/129700. Fort Collins, Colorado: National Park Service.

Brown, Frank S. 1853. "Voyage to San Francisco and the Port of Boston in the Ship Masconomo.” Frank S. Brown Papers. San Francisco Maritime Research Library.

Bruggeman, Seth C. 2006. George Washington Birthplace National Monument: Administrative History 1930-2000. U.S. Department of the Interior, National Park Service.

Brumann, Christoph. 2015. "Cultural Heritage." International Encyclopedia of the Social \& Behavioral Sciences. Amsterdam, Netherlands: Elsevier. 
Byrne, Robert J., and Gary L. Anderson. 1977. "Shoreline Erosion in Tidewater Virginia." Special Report in Applied Marine Science and Ocean Engineering 8. Chesapeake Research Consortium Report. Gloucester Point, Virginia: Virginia Institute of Marine Science.

Caffrey, Maria A., and Rebecca L. Beavers. 2013. "Planning for the Impact of Sea-Level Rise on U.S. National Parks.” Park Science 30 (1): 6-13.

Californian. 1871. “The Olden Time," September 30, 1871. Carton 18, Folder 1, San Francisco, Bancroft Reference Notes for California, [ca. 1870-1890]. Bancroft Library, University of California, Berkeley, California.

Carey, Mark, Philip Garone, Adrian Howkins, Georgina Endfield, Lawrence Culver, Sherry Johnson, Sam White, and James Roger Fleming. 2014. "Forum: Climate Change and Environmental History." Environmental History, 281-364.

Carlton, Stuart J., and Susan K. Jacobson. 2013. "Climate Change and Coastal Environmental Risk Perceptions in Florida.” Journal of Environmental Management 130 (30): 32-39.

Cassar, May. 2005. "Climate Change and the Historic Environment.” London: Center for Sustainable Heritage, University College London. http://discovery.ucl.ac.uk/2082/1/2082.pdf.

Chakrabarty, Dipesh. 2009. "The Climate of History: Four Theses." Critical Inquiry 35: 197-222.

- 2012. "Postcolonial Studies and the Challenge of Climate Change." New Literary History 43 (1): 1-18.

Chambers, Thomas A. 2012. Memories of War: Visiting Battlegrounds and Bonefields in the Early American Republic. Ithaca, New York: Cornell University Press.

Charles Hall Page \& Associates, Inc. 1977. "Survey of Cultural Resources Piers 14-22 1/2 The Agricultural Building \& The Fire Boat House, The Port of San Francisco." San Francisco, California. San Francisco Maritime Research Library.

Charlier, Roger H., Marie Claire P. Chaineux, and Selim Morcos. 2005. "Panorama of the History of Coastal Protection.” Journal of Coastal Research 21 (1): 79-111.

Charls Johnsson and Kate Johnsson. 1906. Washington, D.C.

Chatelain, Verne E. 1941. The Defenses of Spanish Florida, 1565-1763. Washington, D.C.: Carnagie Institute of Washington.

Chess, Caron, and Branden B. Johnson. 2007. "Information Is Not Enough." In Creating a Climate for Change: Communicating Climate Change and Facilitating Social Change, 223-33. Cambridge, United Kingdom: Cambridge University Press.

Chiang, Connie Y. 2005. Shaping the Shoreline: Fisheries and Tourism on the Monterey Coast. Seattle, Washington: Washington University Press. 
Chief of Engineers. 1870. Annual Report of the Chief of Engineers to the Secretary of War for the Year 1870. Washington, D.C.: Government Printing Office.

1874. Annual Report of the Chief of Engineers to the Secretary of War for the Year 1874. 2 vols. Washington, D.C.: Government Printing Office.

- 1879. Annual Report of the Chief of Engineers, United States Army, to the Secretary of War for the Year 1879, Part I. Washington, D.C.

- 1897. Annual Report of the Chief of Engineers to the Secretary of War for the Year 1897, Part II. Washington, D.C.: Government Printing Office.

- 1904. Annual Report of the Chief of Engineers to the Secretary of War for the Year 1904. Washington, D.C.: Government Printing Office.

Choi, Charles Q. 2017. "Rising Seas Could Submerge the Oldest English Settlement in the Americas." Live Science. November 30, 2017. https://www.livescience.com/61063-rising-seas-may-destroy-archeologicalsites.html.

"City Slip Sale." 1853. Carton 5, Folder 5 Land: San Francisco, Bancroft Reference Notes for California, [ca. 1870-1890]. Bancroft Library, University of California, Berkeley, California.

Claesson, Stefan. 2011. "The Value and Valuation of Maritime Cultural Heritage." International Journal of Cultural Property 18: 61-80.

Clapperton, Jonathan. 2012. "Desolate Viewscapes: Sliammon First Nation, Desolation Sound Marine Park and Environmental Narratives." Environment and History 18 (4): 529-59.

"Climate Change Impacts in the United States: The Third National Assessment." 2012. Washington, D.C.: United States Global Climate Change Research Program.

"Climate Change Threatens to Sweep Away Historic Jamestown Settlement." 2014. The Guardian. June 5, 2014.

https://www.theguardian.com/world/2014/jun/05/jamestown-settlement-risingsea-level-threat.

Coker, William S. 1999. "Pensacola, 1686-1821.” In Archaeology of Colonial Pensacola, edited by Judith A. Bense, 5-60. Gainsville, Florida: University Press of Florida.

Colmer, William N. 1970. "Colmer to Hickel.” Record Group 79 Records of the National Park Service, Administrative Files, 1949-1971, Box 2745. National Archives, College Park, Maryland.

Colton. 1930. To Provide for the Creation of the Colonial National Monument in the Commonwealth of Virginia. Washington, D.C.

Colwell, Rita, Susan Avery, Joel Berger, Gary E. Davis, Healy Hamilton, Thomas Lovejoy, Shirley Malcom, et al. 2012. "Revisting Leopold: Resource Stewardship 
in the National Parks.” Washington, D.C.: National Park System Advisory Board Science Committee.

“Commndr Josef Arguello Annual Report to Govr.” n.d. Carton 16, Folder 15, San Francisco, Bancroft Reference Notes for California, [ca. 1870-1890]. Bancroft Library, University of California, Berkeley, California.

“Comnte to Govr." 1794. Carton 16, Folder 13, San Francisco, Bancroft Reference Notes for California, [ca. 1870-1890]. Bancroft Library, University of California, Berkeley, California.

Congress. 1971. "Pubic Law 91-660.” Gulf Islands National Seashore Papers Box 2, Folder 8. University of West Florida Archive and West Florida History Center.

Conomos, T.J., R.E. Smith, and J.W. Gartner. 1985. "Environmental Setting of San Francisco Bay.” Hydrobiologia 129 (1): 1-12.

Conte, Fred S. 1996. “California Oyster Culture.” University of California, Davis Department of Animal Science. http://aqua.ucdavis.edu/DatabaseRoot/pdf/ASAQ-A07.PDF.

Coombes, Paul, and Keith Barber. 2005. "Environmental Determinism in Holocene Research: Causality or Coincidence?” Area 37 (3): 303-11. https://doi.org/10.1111/j.1475-4762.2005.00634.x.

Coombs. 1902. Light and Fog-Signal Station in San Francisco Bay. Washington, D.C.

Corson, James W. 1972. "Interpretive Prospectus, Jamestown Island.” Record Group 79, Division of Interpretive Planning, Records of Public Input Documenting Interpretive Planning Activities, 1955-1999, Box 58. National Archives, College Park, Maryland.

Cotter, John L. 1954. "Recommendation for Permanent Preservation of Exposed Masonry Foundations.” Record Group 79 Records of the National Park Service, Administrative Files, 1949-1971, Box 1459. National Archives, College Park, Maryland.

. 1955. "Preservation of Excavated Structures." Record Group 79 Records of the National Park Service, Administrative Files, 1949-1971, Box 1459. National Archives, College Park, Maryland.

Cox, Julian V. 1966a. "Cox to Colmer." Record Group 79 Records of the National Park Service, Administrative Files, 1949-1971, Box 1997. National Archives, College Park, Maryland.

_. 1966b. "This Is in Response To..." Record Group 79 Records of the National Park Service, Administrative Files, 1949-1971, Box 1997. National Archives, College Park, Maryland.

Crate, Susan A. 2008. "Gone the Bull of Winter?: Grappling with the Cultural Implications of and Anthropology's Role(s) in Global Climate Change." Current Anthropology 49 (4): 569-95. https://doi.org/10.1086/529543. 
- 2011. "Climate and Culture: Anthropology in the Era of Contemporary Climate Change." Annual Review of Anthropology 40: 175-94.

Creswell, John. 2014. Research Design: Qualitative, Quantitative, and Mixed Methods. 4th edition. Thousand Oaks, California: Sage Publications.

Cronon, William. 1993. "The Uses of Environmental History." Environmental History Review 17 (3): 1-22.

. 1995. "The Trouble with Wilderness or, Getting Back to the Wrong Nature." In Uncommon Ground: Toward Reinventing Nature, edited by William Cronon, $7-$ 28. New York City, New York: W.W. Norton \& Company, Inc.

—. 2000. "Why the Past Matters." Wisconsin Magazine of History, Autumn 2000.

.2003a. Changes in the Land: Indians, Colonists, and the Ecology of New England. New York City, New York: Hill and Wang.

_. 2003b. "The Riddle of the Apostle Islands." Orion, June, 36-42.

- 2004. "Getting Ready to Do History." Carnagie Essays on the Doctorate, 1-18.

Crosson, Tom. 2017. "National Park Service Applauds President Obama's Diversity Commitment and Outlines Efforts to Engage All Americans in Their National Parks." National Park Service Office of Communications (blog). January 13, 2017. https://www.nps.gov/orgs/1207/01-13-2017-promoting-diversity.htm.

Daire, Marie-Yvane, Elias Lopez-Romero, Jean-Noel Proust, Herve Regnauld, Soazig Pian, and Benheng Shi. 2012. "Coastal Changes and Cultural Heritage: Assessment of the Vulnerability of the Coastal Heritage in Western France." Journal of Island Coastal Archaeology 7: 168-82.

Dake, Karl. 1992. "Myths of Nature: Culture and the Social Construction of Risk." Journal of Social Issues 48 (4): 21-37.

Dallas, Kate, Michael Berry, and Peter Ruggiero. 2013. "Inventory of Coastal Engineering Projects in Colonial National Historical Park." Natural Resource Technical Report NPS/NRSS/GRD/NRTR--2013/690. Fort Collins, Colorado: National Park Service.

Daly, Cathy. 2011. "Climate Change and the Conservation of Archaeological Sites: A Review of Impacts Theory." Conservation and Management of Archaeological Sites 13 (4): 293-310.

Deans, Bob. 2007. The River Where America Began: A Journey Along the James. Lanham, Maryland: Rowman \& Littlefield Publishers, Inc.

"Dec. 6 1839." 1839. Carton 17, Folder 1, San Francisco, Bancroft Reference Notes for California, [ca. 1870-1890]. Bancroft Library, University of California, Berkeley, California.

Delach, Aimee, and Noah Matson. 2010. "Climate Change and Federal Land Management: A Comparison of the U.S. Fish \& Wildlife Service, National Park 
Service, and U.S. Forest Service Climate Change Strategies." Washington, D.C.: Defenders of Wildlife.

Delgado, James. 1981. "Pioneers, Politics, Progress, and Planning: The Story of San Francisco's Aquatic Park." Golden Gate National Recreation Area. . 2009. Gold Rush Port: The Maritime Archaeology of San Francisco's Waterfront. Berkeley, California: University of the West Indies.

Demaray, A.E. 1935. "The Government Wharf at Yorktown, Virginia.” Record Group 79, Central Classified File, 1933-1949, Box 1976. National Archives, College Park, Maryland.

Demonocal, Peter B. 2001. "Cultural Responses to Climate Change During the Late Holocene.” Science 292: 667-73.

Department of the Interior. n.d. "The Advanced Redoubt of Fort Barrancas." Gulf Islands National Seashore Papers Box 4, Folder 3. University of West Florida Archive and West Florida History Center.

_ 1977. "Gulf Islands National Seashore Advisory Commission Meeting." Gulf Islands National Seashore Papers Box 4, Folder 3. University of West Florida Archive and West Florida History Center.

DeRouen. 1938. Revising the Boundaries of the Colonial National Historical Park in the State of Virginia. Washington, D.C.

DeSilvey, Caitlin. 2012. "Making Sense of Transience: An Anticipatory History." Cultural Geographies 19 (1): 31-54.

Diamond, Jared. 2011. Collapse: How Societies Choose to Fail or Succeed. 2nd ed. New York City, New York: Viking Press.

"Diary of a Forty-Niner." 1849. Carton 17, Folder 10, San Francisco, Bancroft Reference Notes for California, [ca. 1870-1890]. Bancroft Library, University of California, Berkeley, California.

Doe, John. 1852. "Sacramento During the Last Twenty Years." Carton 17, Folder 11, San Francisco, Bancroft Reference Notes for California, [ca. 1870-1890]. Bancroft Library, University of California, Berkeley, California.

DOI. 1935. "Specifications for Constructing Riprap Walls on Section A on the James River, Jamestown Island, Virginia.” Record Group 79, Central Classified File, 1933-1949, Box 1976. National Archives, College Park, Maryland.

Dorsey, Leroy G. 1995. "The Frontier Myth in Presidential Rhetoric: Theodore Roosevelt's Campaign for Conservation.” Western Journal of Communication 59 (1): 1-19.

Dow, Gerald Robert. 1973. "Bay Fill in San Francisco: A History of Change.” Masters Thesis, San Francisco, California: San Francisco State University. William W. Helbush Papers, Folder 1. San Francisco Maritime Research Library. 
Dreyfus, Philip J. 2008. Our Better Nature: Environment and the Making of San Francisco. Norman, Oklahoma: University of Oklahoma Press.

Eisenack, Klaus, Susanne C. Moser, Esther Hoffmann, Richard J.T. Klein, Christoph Oberlack, Anna Pechan, Maja Rotter, and Catrien J.A.M. Termeer. 2014. "Explaining and Overcoming Barriers to Climate Change Adaptation." Nature Climate Change, September. https://doi.org/10.1038/NCLIMATE2350.

Ellenwood, Mikaela S., Lisa Dilling, and Jana B. Milford. 2012. "Managing United States Public Lands in Response to Climate Change: A View from the Ground Up.” Environmental Management 49: 954-67.

Emery, George F. 1954. "Emery to Regional Director." Record Group 79, Records of the National Park Service, Administrative Files, 1949-1971, Box 638. National Archives, College Park, Maryland.

Engineering News-Record. 1926. "Hurricane Damage at Pensacola, Fla.," October 14, 1926. Hurricane Damage at Pensacola, Florida. University of West Florida Archive and West Florida History Center.

Erlandson, Jon McVey. 2012. "As the World Warms: Rising Seas, Coastal Archaeology, and the Erosion of Maritime History." Journal of Coastal Conservation 16: 13742.

Fassett. 1910. Panama-Pacific International Exposition. Washington, D.C.

Fatoric, Sandra, and Erin Seekamp. 2017a. "Securing the Future of Cultural Heritage by Identifying Barriers to and Strategizing Solutions for Preservation Under Changing Climate Conditions." Sustainability 9: 21-43.

- 2017b. "Are Cultural Heritage and Resources Threatened by Climate Change? A Systematic Literature Review." Climatic Change 142 (1): 227-54.

Faye, Stanley. 1941. "Spanish Fortifications of Pensacola, 1698-1763.” The Florida Historical Quarterly 20 (2): 151-68.

Feiler, Seymour, trans. 1962. Jean-Bernard Bossu's Travels in the Interior of North America, 1751-1762. Norman, Oklahoma: University of Oklahoma Press.

Finley, Carmel, and Naomi Oreskes. 2013. "Food for Thought: Maxiumum Sustainable Yield: A Policy Disguised as Science.” ICES Journal of Marine Science 70 (2): 245-50.

Fitzpatrick, Scott M., Michiel Kappers, and Quetta Kaye. 2006. "Coastal Erosion and Site Destruction on Carriacou, West Indies.” Journal of Field Archaeology 31 (3): 251-62.

Flader, Susan L. 1998. "Citizenry and the State in the Shaping of Environmental Policy." Environmental History 3 (1): 8-24. 
Flickinger, B. Floyd. 1935. "Flickinger to the Director." Record Group 79 Records of the National Park Service, Narrative Reports Concerning CCC Projects in Nat'1 Park Service Areas, 1933-1935, Box 31. National Archives, College Park, Maryland.

Flint McClelland, Linda. 1998. Building the National Parks: Historic Landscape Design and Construction. Baltimore, Maryland: The Johns Hopkins University Press.

Florida Department of Environmental Protection, Division of Water Resources Management, Bureau of Beaches and Coastal Systems. 2006. "Hurricane Dennis and Hurricane Katrina: Final Report on 2005 Hurricane Season Impacts to Northwest Florida." Tallahassee, Florida.

Flyvbjerg, Bent. 2006. "Five Misunderstandings About Case-Study Research." Qualitative Inquiry 12 (2): 219-45. https://doi.org/10.1177/1077800405284363.

"Fortifications Pensacola Harbor." 1827. Secretary of War, Individual Files. University of West Florida Archive and West Florida History Center.

Foster, John. 1824. A Sketch of the Tour of the General Lafayette, on His Late Visit to the United States. Portland, Maine: A.W. Thayer.

"From the 1820 s to the Gold Rush." n.d. The Virtual Museum of the City of San Francisco. Accessed October 5, 2017. http://www.sfmuseum.org/hist1/early.html.

Frye. 1907. Additional Aids to Navigation in Light-House Establishment, Etc. Washington, D.C.

Fussel, Hans-Martin. 2007. "Adaptation Planning for Climate Change: Concepts, Assessment Approaches, and Key Lessons.” Sustainability Science 2: 265-75.

Fussel, Hans-Martin, and J.T. Klein. 2006. "Climate Change Vulnerability Assessments: An Evolution of Conceptual Thinking." Climatic Change 75: 301-29.

Gaston, Joel. 1967. "Proposed Seashore Features Recreation, Beauty, History," November 12, 1967.

Geiter, Mary K., and W.A. Speck. 2002. Colonial America from Jamestown to Yorktown. American History in Depth. New York City, New York: Palgrave MacMillan.

“General Account of Progress Section 195 1870." 1870. Carton 18, Folder 1, San Francisco, Bancroft Reference Notes for California, [ca. 1870-1890]. Bancroft Library, University of California, Berkeley, California.

Gillis, John R. 2012. The Human Shore. Chicago, Illinois: The University of Chicago Press.

Gissy, E.A. varies. "All of the CCC Camp Reports Starting with April 1, 1935-September 30, 1935 and Ending With." Record Group 79 Records of the National Park Service, Narrative Reports Concerning CCC Projects in Nat'l Park Service Areas, 1933-1935, Box 31. National Archives, College Park, Maryland. 
Glacken, Clarence J. 1967. Traces on the Rhodian Shore: Nature and Culture in Western Thought from Ancient Times to the End of the Eighteenth Century. Berkeley, California: University of California Press.

Glick, P., B.A. Stein, and N.A. Edelson. 2011. Scanning the Conservation Horizon: A Guide for Climate Change Vulnerability Assessment. Washington, D.C.: National Wildlife Federation.

Godfrey, Brian J. 1997. "Urban Development and Redevelopment in San Francisco.” The Geographical Review 87 (3): 309-33.

Gold, Robert L. 1969. Borderland Empires in Transition: The Triple-Nation Transfer of Florida. Carbondale, Illinois: Southern Illinois University Press.

Goldberger, Sarah. 2014. "Seizing the Past: Revolutionary Memory and the Civil War in Yorktown." Virginia Magazine of History \& Biography 122 (2): 97.

Golden Gate National Parks Conservancy. 2016. "Crissy Field and Sea Level Rise Up: Rise-up Community Workshop and Sea Level Rise Analysis.” Golden Gate National Parks Conservancy.

Goldman, Harold B. 1969a. “Geology of San Francisco Bay.” Special Report 97. Geologic and Engineering Aspects of San Francisco Bay Fill. San Francisco, California: California Division of Mines and Geology. . 1969b. "Salt, Sand and Shells: Mineral Resources of the San Francisco Bay." Special Report 97. Geologic and Engineering Aspects of San Francisco Bay Fill. San Francisco, California: California Division of Mines and Geology.

Goman, M., F. Malamud-Roam, and B.L. Ingram. 2008. "Holocene Environmental History and Evolution of a Tidal Salt Marsh in San Francisco Bay, California." Journal of Coastal Research 24 (5): 1126-37.

Gonzalez, Patrick. 2015. “Climate Change Summary, San Francisco Maritime National Historical Park, California.” Natural Resource Stewardship and Science, U.S. Naitonal Park Service, Washington, DC.

- 2016. "Climate Change in the National Parks of the San Francisco Bay Area, California, USA."

Goodwin, William A.R. 1931. "Goodwin to Cramton.” Record Group 79, Central Classified File, 1933-1949, Box 1975. National Archives, College Park, Maryland.

Goudie, Andrew. 2013. The Human Impact on the Natural Environment. 7th ed. Cambridge, Massachusetts: The MIT Press.

Gould, Alec. 1994a. “Superintendent's Annual Report 1993.” Record Group 79, Division of Land Acquisition, Land Acquisition Files, 1933-1970, Box 15. National Archives, College Park, Maryland. 
_. 1994b. "Superintendent's Annual Report 1992." Record Group 79, Division of Land Acquisition, Land Acquisition Files, 1933-1970, Box 15. National Archives, College Park, Maryland.

"Gov to VR." 1794. Carton 16, Folder 13, San Francisco, Bancroft Reference Notes for California, [ca. 1870-1890]. Bancroft Library, University of California, Berkeley, California.

"Govr to VR." 1806. Carton 16, Folder 16, San Francisco, Bancroft Reference Notes for California, [ca. 1870-1890]. Bancroft Library, University of California, Berkeley, California.

Graham, Brian, G.J. Ashworth, and J.E. Tunbridge. 2000. A Geography of Heritage. New York City, New York: Arnold Publishers.

Green, Thomas J. 2015. "Cultural Resource Management: Conservation of Cultural Heritage." International Encyclopedia of the Social \& Behavioral Sciences. Amsterdam, Netherlands: Elsevier.

Greene, Jennifer C., Valerie J. Caracelli, and Wendy F. Graham. 1989. "Toward a Conceptual Framework for Mixed-Method Evaluation Designs." Educational Evaluation and Policy Analysis 11 (3): 255-74.

Gregory, George C. 1931. "Gregory to Peterson." Record Group 79 Records of the National Park Service, Classified Files, 1927-1931, Box 53. National Archives, College Park, Maryland.

Grigg, Susan. 1991. "Archival Practice and the Foundations of Historical Method." The Journal of American History 78 (1): 228-39.

Grimmer, Anne E. 2017. “The Secretary of the Interior's Standards for the Treatment of Historic Properties with Guidelines for Preserving, Rehabilitating, Restoring \& Reconstructing Historic Buildings." U.S. Department of the Interior. https://www.nps.gov/tps/standards/treatment-guidelines-2017.pdf.

Groenewoudt, B.J. 2012. "History Continuous: Drowning and Desertification. Linking Past and Future in the Dutch Landscape." Quaternary International 251: 125-35.

Groot, Jerome de. 2009. Consuming Heritage: Historians and Heritage in Contemporary Popular Culture. New York City, New York: Routledge.

Grove, Richard H. 1996. Green Imperialism: Colonial Expansion, Tropical Island Edens and the Origins of Environmentalism, 1600-1860. Cambridge: Cambridge University Press.

Guerrini, Anita, and Jenifer E. Dugan. 2010. "Informing Ecological Restoration in a Coastal Context." In Restoration and History: The Search for a Usable Environmental Past, 131-42. New York City, New York: Routledge.

Guest, Greg. 2015. "Sampling and Selecting Participants in Field Research." In Handbook of Methods in Cultural Anthropology, 2nd ed., 215-50. Lanham, Maryland: Rowman and Littlefield. 
"GUIS Advisory Committee Meeting Minutes." 1980. Gulf Islands National Seashore Papers Box 4, Folder 3. University of West Florida Archive and West Florida History Center.

"Gulf Islands National Seashore 1990 Annual Narrative Report." 1990. Record Group 79 Records of the National Park Service, Superintendent's Annual Narrative Reports, 1980-2001, Box 28. National Archives, College Park, Maryland.

"Gulf Islands National Seashore Advisory Committee Meeting." 1973. Gulf Islands National Seashore Papers Box 3, Folder 4. University of West Florida Archive and West Florida History Center.

"Gulf Islands National Seashore History and Status Outline Summary." n.d. Gulf Islands National Seashore Papers Box 2, Folder 11. University of West Florida Archive and West Florida History Center.

"Gulf Islands National Seashore Statement for Management." 1980. Gulf Islands National Seashore Papers Box 5, Folder 8. University of West Florida Archive and West Florida History Center.

"Gulf Islands National Seashore Superintendent's Annual Narrative Report." 1986. Record Group 79 Records of the National Park Service, Superintendent's Annual Narrative Reports, 1980-2001, Box 28. National Archives, College Park, Maryland.

Hale. 1907. Harbor Accommodations for Vessels. Washington, D.C.

Hale, Edward E., ed. 1860. "Ralph Lane to Sir Francis Walsingham, 12th August 1585." In Original Documents from the State-Paper Office, London, and the British Museum; Illustrating the History of Sir Walter Raleigh's First American Colony and the Colony at Jamestown. With an Appendix Containing a Memoir of Sir Ralph Land, The Governor of the Colony of Roanoke. Boston, Massachusetts: John Wilson and Son.

Hardaway, Jr., C.S., and R.J. Byrne. 1999. "Shoreline Management in Chesapeake Bay." Special Report in Applied Marine Science and Ocean Engineering 356. Gloucester Point, Virginia: Virginia Institute of Marine Science and Virginia Sea Grant.

Harlow, Neal. 1982. California Conquered: The Annexation of a Mexican Province, 1846-1850. Berkeley, California: University of California Press.

Harrington, Julie, and Todd L. Walton, Jr. 2008. "Climate Change in Coastal Areas in Florida: Sea Level Rise Estimation and Economic Analysis to Year 2080." Tallahassee, Florida: The Florida State University.

Hart. 1972. San Francisco Bay National Wildlife Refuge. Washington, D.C.

Haugen, Annika, and Johan Mattsson. 2011. "Preparations for Climate Change's Influences on Cultural Heritage." International Journal of Climate Change Strategies and Management 3 (4): 386-401. 
Hays, Samuel P. 1980. Conservation and the Gospel of Efficiency. New York City, New York: Atheneum.

1999. Conservation and the Gospel of Efficiency: The Progressive Conservation Movement, 1890-1920. Pittsburgh, Pennsylvania: University of Pittsburg Press.

Herbert, Steve. 2010. "A Taut Rubber Band: Theory and Empirics in Qualitative Geographic Research.” In The Sage Handbook of Qualitative Geography, 69-81. Thousand Oaks, California: Sage Publications.

Hoffman, Paul E. 2002. Florida's Frontiers. A History of the Trans-Appalachain Frontier. Bloomington, Indiana: Indiana University Press.

Holtz, Debra, Adam Markham, Kate Cell, and Brenda Ekwurzel. 2014. "National Landmarks at Risk: How Rising Seas, Floods, and Wildfires Are Threatening the United States' Most Cherished Historical Sites." Union of Concerned Scientists. http://www.ucsusa.org/sites/default/files/legacy/assets/documents/global_warmin g/National-Landmarks-at-Risk-Full-Report.pdf.

Hosmer, Jr., Charles B. 1981a. Preservation Comes of Age: From Williamsburg to the National Trust, 1926-1949. Vol. I. Charlottesville, Virginia: University of Virginia Press.

. 1981b. Preservation Comes of Age: From Williamsburg to the National Trust, 1926-1949. Vol. II. Charlottesville, Virginia: University of Virginia Press.

Hulme, Mike. 2008. "Geographical Work at the Boundaries of Climate Change." Transactions of the Institute of British Geographers 33 (1): 5-11. https://doi.org/10.1111/j.1475-5661.2007.00289.x.

_. 2011. "Meet the Humanities." Nature Climate Change 1 (June): 177-79. https://doi.org/10.1038/nclimate1150.

Hunt, Terry, and Carl Lipo. 2011. The Statues That Walked: Unraveling the Mystery of Easter Island. New York City, New York: Free Press.

"In 1850 the Bay Of..." 1850. Carton 17, Folder 11, San Francisco, Bancroft Reference Notes for California, [ca. 1870-1890]. Bancroft Library, University of California, Berkeley, California.

IPCC. 2014. "Climate Change 2014: Impacts, Adaptation and Vulnerability." Contribution of Working Group II to the Fifth Assessment Report of the Intergovernmental Panel on Climate Change. Part A: Global and Sectoral Aspects. New York City, New York: Cambridge University Press.

Jamestown Rediscovery. n.d. "History of Preservation Virginia." Accessed August 8, 2017. http://historicjamestowne.org/about/history-of-apva/.

Jantarasami, Lesley C., Joshua J. Lawler, and Craig W. Thomas. 2010. "Institutional Barriers to Climate Change Adaptation in U.S. National Parks and Forests." Ecology and Society 15 (4): 33. 
Jarvis, Jonathan. 2009. Statement of Johnathan B. Jarvis, Director, National Park Service, U.S. Department of the Interior, Before the Senate Committee on Energy and Natural Resources Subcommittee on National Parks, on Climate Change in National Parks. Washington, D.C.

- 2014. "Policy Memorandum 14-02: Climate Change and Stewardship of Cultural Resources." National Park Service.

—. 2016. "Director's Order \#100: Resource Stewardship for the 21st Century."

Jasanoff, Sheila. 1987. "Cultural Aspects of Risk Assessment in Britain and the United States." In The Social and Cultural Construction of Risk: Essays on Risk Selection and Perception, 359-97. Boston, Massachusetts: D. Reidel Publishing Company.

Jensen, John Odin, and Alexander Hartmeyer. 2014. "A Cultural Landscape Approach (CLA) Overview and Sourcebook for Wisconsin's Mid-Lake Michigan Maritime Heritage Trail Region." National Oceanic and Atmospheric Administration Office of National Marine Sanctuaries. http://www.appliedhistory.org/wp-

content/uploads/2015/01/Mid-Lake-Michigan-Cultural-Landscape-SourceBook.pdf.

"John Coffee Hays: San Francisco's First Elected Sheriff." n.d. History of the San Francisco Sheriff's Department. Accessed October 8, 2017. http://www.sfsdhistory.com/eras/john-coffee-hays-san-franciscos-first-electedsheriff.

Johnson. 1929. Bridge Across San Francisco Bay. Washington, D.C.

Johnson, Jeffrey C., and Daniel J. Hruschka. 2015. "Research Design and Research Strategies." In Handbook of Methods in Cultural Anthropology, 2nd ed., 97-130. Lanham, Maryland: Rowman and Littlefield.

Jones. 1911. Panama-Pacific International Exposition. Washington, D.C. 1988. Enlargement of the San Francisco Bay National Wildlife Refuge. Washington, D.C.

Joyce, Christopher. 2013. "With Rising Seas, America's Birthplace Could Disappear." National Public Radio. May 14, 2013. http://www.npr.org/2013/05/14/178809495/with-rising-seas-americas-birthplacecould-disappear.

Kahn. 1912. Panama Pacific International Exposition Co. Washington, D.C.

Kahn, Judd. 1979. Imperial San Francisco: Politics and Planning in an American City, 1897-1906. Lincoln, Nebraska: University of Nebraska Press.

Kahrl, Andrew. 2014. "The Sunbelt's Sandy Foundation: Coastal Development and the Making of the Modern South.” Southern Cultures 20 (3): 24-42. 
Kawashima, Yasuhide, and Ruth Tone. 1983. "Environmental Policy in Early America: A Survey of Colonial Statues." Journal of Forest History, October, 168-79.

Kearny, S.W. 1847a. “Appendix No. 10.” Carton 5, Folder 5 Land: San Francisco, Bancroft Reference Notes for California, [ca. 1870-1890]. Bancroft Library, University of California, Berkeley, California.

_. 1847b. "Sir: Your Letter of The..." Carton 5, Folder 5 Land: San Francisco, Bancroft Reference Notes for California, [ca. 1870-1890]. Bancroft Library, University of California, Berkeley, California.

Kelman, Ari. 2007. “Boundary Issues: Clarifying New Orleans's Murky Edges.” Journal of American History 94 (3): 695-703.

Kemble, John Haskell. 1978. San Francisco Bay: A Pictoral Maritime History. New York City, New York: Bonanza Books.

Kemp, Kerry B., Jarod J. Blades, P. Zion Klos, Troy E. Hall, Jo Ellen Force, Penelope Morgan, and Wade T. Tinkham. 2015. "Managing for Climate Change on Federal Lands of the Western United States: Perceived Usefulness of Climate Science, Effectiveness of Adaptation Strategies, and Barriers to Implementation.” Ecology and Society 20 (2): 17-.

Khaw, Cassandra. 2014. "Historic Jamestown Will Likely Be Underwater by the End of the Century." The Verge. June 6, 2014.

https://www.theverge.com/2014/6/6/5785270/jamestown-at-risk-from-rising-sealevel.

King, Thomas F. 2000. Federal Planning and Historic Places. Walnut Creek, California: AltaMira Press.

- 2004. Cultural Resource Laws and Practices: An Introductory Guide. Walnut Creek, California: AltaMira Press.

Kiracofe, David James. 2002. "The Jamestown Jubilees: "State Patriotism and Virginia Identity in the Early Nineteenth Century." The Virginia Magazine of History and Biography 110 (1): 35-68.

Kitchin, Thomas. 1781. "Map of the Province of West Florida." London: R. Baldwin. Florida Map Collection. State Library of Florida. https://www.floridamemory.com/items/show/323242.

Kopp, Robert E., Andrew C. Kemp, Klaus Bittermann, Benjamin P. Horton, Jeffrey P. Donnelly, W. Roland Gehrels, Carling C. Hay, Jerry X. Mitrovica, Eric D. Morrow, and Stefan Rahmstorf. 2016. "Temperature-Driven Global Sea Level Variability in the Common Era." Proceedings of the National Academy of Sciences, February, E1434-1441.

Kotzubue, Admiral Otto von. 1867. “A Memorable California Winter.” San Francisco Bulletin, January 11, 1867. Carton 21, Folder 18, San Francisco, Bancroft Reference Notes for California, [ca. 1870-1890]. Bancroft Library, University of California, Berkeley, California. 
Krippendorf, Klaus. 1996. Content Analysis: An Introduction to Its Methodology. Beverly Hills, California: Sage Publications.

Kummu, Matti, Hans de Moel, Gianluigi Salvucci, Daniel Viviroli, Philip J. Ward, and Olli Varis. 2016. "Over the Hills and Further Away from the Coast: Global Geospatial Patterns of Human and Environment over the 20th-21st Centuries." Environmental Research Letters 11 (3). https://doi.org/10.1088/17489326/11/3/034010.

Kupperman, Karen Ordahl. 1982. "The Puzzle of the American Climate in the Early Colonial Period." The American Historical Review 87 (5): 1262-89.

Langelier, John Phillip, and Daniel Bernarn Rosen. 1992. "Historic Resource Study: El Presidio de San Francisco, A History under Spain and Mexico, 1776-1846." National Park Service.

Lazrus, Heather. 2012. "Sea Change: Island Communities and Climate Change." Annual Review of Anthropology 41: 285-301.

Lee, Charles H., and Michael Praszker. 1969. "Bay Mud Developments and Related Structural Foundations.” Special Report 97. Geologic and Engineering Aspects of San Francisco Bay Fill. San Francisco, California: California Division of Mines and Geology.

Lee, Ronald F. 1956. "Final Mission 66 Prospectus - Colonial NHP." Record Group 79, Records of the National Park Service, Administrative Files, 1949-1971, Box 732. National Archives, College Park, Maryland.

Lemieux, Christopher J., Jessica L. Thompson, Jackie Dawson, and Rudy M. Schuster. 2013. "Natural Resource Manager Perceptions of Agency Performance on Climate Change.” Journal of Environmental Management 114 (15): 178-89.

Leonard, Irving A. 1939. Spanish Approach to Pensacola, 1689-1693. Albuquerque, New Mexico: The Quivira Society.

Leopold, A.S., S.A. Cain, C.M. Cottam, I.N. Gabrielson, and T.L. Kimball. 1963. "Wildlife Management in the National Parks: The Leopold Report."

Lewis, Emanuel Raymond. 1970. Seacoast Fortifications of the United States: An Introductory History. Washington, D.C.: Smithsonian Institution Press.

Lowenthal, David. 1996. Possessed by the Past: The Heritage Crusade and the Spoils of History. New York City, New York: The Free Press.

- 2015. The Past Is a Foreign Country-Revisited. Cambridge: Cambridge University Press.

Luby, Edward M., Clayton D. Drescher, and Kent G. Lightfoot. 2006. "Shell Mounds and Mounded Landscapes in the San Francisco Bay Area: An Integrated Approach." The Journal of Island and Coastal Archaeology 1 (2): 191-214. https://doi.org/10.1080/15564890600935365. 
Luhmann, Niklas. 2008. Risk: A Sociological Theory. Translated by Rhodes Barrett. 4th ed. New Brunswick, New Jersey: Aldine Transaction.

Lujala, Paivi, Haakon Lein, and Jan Ketil Rod. 2015. "Climate Change, Natural Hazards, and Risk Perception: The Role of Proximity and Personal Experience." Local Environment 20 (4): 489-509.

Mabelitini, Brian. 2011. "Historical Background of the Fort Pickens Wharf (1828-1947), Santa Rosa Island, FL." Report of Investigations 177. Pensacola, Florida: University of West Florida.

Maeder, Richard H. 1987. "Superintendent's Annual Report, Calendar Year 1980: Colonial National Historical Park, Yorktown, Virginia." Record Group 79, Superintendents Annual Narrative Reports, 1980-2001, Box 14. National Archives, College Park, Maryland.

Mahan, Helen. 2015. "Fulfilling the Promise of 'Parks to People' in a Changing Environment: The Gateway National Recreation Area Experience." The George Wright Forum 32 (1): 51-58.

Mahoney, Shannon S. 2015. "“Faced with Courage': Interpreting and Presenting Sites of African American Heritage to the Public." Conservation and Management of Archaeological Sites 17 (1): 56-66.

Mallory. 1904. Fog Signal at Quarry Point, California. Washington, D.C.

Manucy, Albert. 1959. "The Founding of Pensacola-Reasons and Reality.” Florida Historical Quarterly 37 (3 and 4): 223-41.

"March 4 1792- Sal to Roman He Encloses a Plan of Presidio (with Explanation)." 1792. Carton 16, Folder 13, San Francisco, Bancroft Reference Notes for California, [ca. 1870-1890]. Bancroft Library, University of California, Berkeley, California.

Marine Protected Areas Federal Advisory Committee. 2011. "Recommendations for Integrated Management Using a Cultural Landscape Approach in the National MPA System."

Markham, Adam, and Jeana Wiser. 2015. “A Heritage Coalition's 'Call to Action' on Climate Change and Cultural Heritage." Forum Journal 29 (4): 19-23.

Marshall, Martin. 1996. “The Key Informant Technique.” Family Practice 13 (1): 92-97.

Mather, Ian Roderick, and John Odin Jensen. 2010. "Cultural and Historic Resources." The Rhode Island Ocean Special Area Management Plan.

_ 2011. "Maritime Heritage Resources at St. Croix Island International Historic Site." Washington, D.C.: National Park Service.

Maynard. 1906. Jamestown Exposition. Washington, D.C.

McDowell, Linda. 2010. "Interviewing: Fear and Liking in the Field." In The Sage Handbook of Qualitative Geography, 156-71. Thousand Oaks, California: Sage Publications. 
McGranahan, Gordon, Deborah Balk, and Bridget Anderson. 2007. “The Rising Tide: Assessing the Risks of Climate Change and Human Settlements in Low Elevation Coastal Zones." Environment and Urbanization 19 (1): 17-37.

McIntosh, Alison J., and Richard C. Prentice. 1999. "Affirming Authenticity: Consuming Cultural Heritage.” Annals of Tourism Research, 589-612.

McKenzie, Matthew. 2010. Clearing the Coastline: The Nineteenth-Century Ecological \& Cultural Transformation of Cape Cod. Lebanon, New Hampshire: University Press of New England.

McReynolds. 1936. San Francisco Bay Exposition in 1939, at San Francisco, California. Washington, D.C.

"Meeting of the Gulf Islands National Seashore Advisory Commission, on Tuesday, December 7, 1971, at 11:00 a.m. in the Conference Room of the Secretary of the Interior." 1971. Gulf Islands National Seashore Papers Box 1, Folder 1. University of West Florida Archive and West Florida History Center.

Meggers, Betty J. 1954. "Environmental Limitation on the Development of Culture." American Anthropologist 56 (5): 801-24.

Meier, Kathryn Shively. 2013. Nature's Civil War: Common Soldiers and the Environment in 1862 Virginia. Chapel Hill, North Carolina: The University of North Carolina Press.

Mellilo, Jerry M., Terese C. Richmond, and Gary W. Yohe. 2014. "Climate Change Impacts in the United States: The Third National Climate Assessment." 841. Washington, D.C.: U.S. Global Climate Change Research Program.

Melnick, Robert Z. 2016. "Deciphering Cultural Landscape Heritage in the Time of Climate Change." Landscape Journal: Design, Planning and Managemnet of the Land 35 (2): 287-302.

Melosi, Martin V. 1993. "Public History and the Environment." The Public Historian 15 (4): $10-20$.

Mergen, Bernard. 2008. Weather Matters: An American Cultural History Since 1900. Lawrence, Kansas: University of Kansas Press.

"Message from the President of the United States, With a Report from the Secretary of War, Transmitting the Inspection Returns of Brevet Major General Gains, for 1826 and 1827, Relating to the Organization of the Army and Militia." 1829. U.S. House of Representatives, Individual Files. University of West Florida Archive and West Florida History Center.

Mette, Herbert B. 1935. "Mette to Roosevelt." Record Group 79 Records of the National Park Service, Records of the Washington Office of the Wildlife Division, 19341936, Box 2. National Archives, College Park, Maryland.

Miller, Clark A. 2000. "The Dynamics of Framing Environmental Values and Policy: Four Models of Societal Processes." Environmental Values 9 (2): 211-33. 
"Minutes GUIS Advisory Commission Meeting." 1980. Gulf Islands National Seashore Papers Box 5, Folder 7. University of West Florida Archive and West Florida History Center.

Moffatt \& Nichol, Engineers, and Wallace Roberts Todd. 1990. "Hyde Street Pier Architectural and Engineering Study." San Francisco, California: National Park Service. San Francisco Maritime Research Library.

Monroe, James. 1822. "Message from the President of the United States, upon the Subject of Fortifications on Dauphine Island and Mobile Point." Gales and Seaton. U.S. President (Monroe), Folder "Message...upon the subject of fortifications on Dauphine Island." University of West Florida Archive and West Florida History Center.

Moore, Sarah J. 2013. Empire on Display: San Francisco's Panama-Pacific International Exposition of 1915. Norman, Oklahoma: University of Oklahoma Press.

Morgan, Marissa, Marcy Rockman, Caitlin Smith, and Alison Meadow. 2016. "Climate Change Impacts on Cultural Resources.” Washington, D.C.: National Park Service Cultural Resources Partnerships and Science.

Morin, Jeane-Pierre. 2017. "Historical Thinking and the Place of History in Public Policy Development.” History@ Work, The National Council on Public History Blog (blog). February 24, 2017. http://ncph.org/history-at-work/historical-thinking-andthe-place-of-history-in-public-policy-development/.

Moser, Suzanne C., and Julia A. Ekstrom. 2010. "Barriers to Climate Change Adaptation: A Diagnostic Framework." Proceedings of the National Academy of Sciences 107 (51): 22026-31.

Moser, Suzanne C., S. Jeffress Williams, and Donald F. Boesch. 2012. "Wicked Challenges at Land's End: Managing Coastal Vulnerability Under Climate Change.” Annual Review of Environment and Resources 37 (November): 51-78.

Moses, Julia, and Eve Rosenhaft. 2015. "Moving Targets: Risk, Security, and the Social in Twentieth Century Europe." Social Science History 39 (1): 24-39.

Nash, Roderick, ed. 1968. The American Environment: Readings in the History of Conservation. Reading, Massachusetts: Addison-Wesley Publishing Company.

Nelson, N.C. 1909. "Shellmounds of the San Francisco Bay Region.” University of California Publications in American Archaeology and Ethnology 7 (4): 310-46.

Neprash, Wallace N. 1989. "Superintendent's Annual Report, Calendar Year 1980: Colonial National Historical Park, Yorktown, Virginia." Record Group 79, Superintendents Annual Narrative Reports, 1980-2001, Box 14. National Archives, College Park, Maryland.

Neuman, W. Lawrence. 1997. Social Research Methods: Qualitative and Quantitative Approaches. Boston, Massachusetts: Allyn and Bacon. 
Nisbet, Matthew C. 2009. "Communicating Climate Change: Why Frames Matter for Public Engagement.” Environment 51 (2): 14-23.

Nix, James Roberts. 1966. "Shadows of the Past of Pensacola Navy Yard, Old Warrington, Woolsey, Fort Barrancas, Fort Pickens, Fort Redoubt As I Knew Them, Also Here and There," 1966. Individual Files. University of West Florida Archive and West Florida History Center.

Nordstrom, Karl F., and Nancy L. Jackson. 2016. "Facilitating Migration of Coastal Landforms and Habitats by Removing Shore Protection Structures: An Adaptation Strategy for Northeast Region Units of the National Park Service." Natural Resource Report NPS/NER/NRR--2016/1240. Fort Collins, Colorado: National Park Service.

NPS. 1945. "Memorandum on the Recreational Resources of Potential Reservoirs of the Upper James River Basin.” Record Group 79, Records of the National Park Service, Administrative Files, 1949-1971, Box 638. National Archives, College Park, Maryland.

. 1954. "Mission 66 for Colonial National Historical Park.” Record Group 79, Division of Interpretive Planning, Records of Public Input Documenting Interpretive Planning Activities, 1955-1999, Box 57. National Archives, College Park, Maryland.

. 1969. "Management Objectives Colonial National Historical Park." Record Group 79, Division of Interpretive Planning, Records of Public Input Documenting Interpretive Planning Activities, 1955-1999, Box 57. National Archives, College Park, Maryland.

1987. "Haslett Warehouse, National Maritime Museum, Golden Gate National Recreation Area." Record Group 79, Division of Interpretive Planning, Records of Public Input Documenting Interpretive Planning Activities, 1955-1999, Box 227. National Archives, College Park, Maryland.

1993. "From Post to Park: A Profile of the National Park Service General Management Plan Amendment for the Presidio of San Francisco." Record Group 79, Division of Interpretive Planning, Records of Public Input Documenting Interpretive Planning Activities, 1955-1999, Box 227. National Archives, College Park, Maryland.

_. 1997. "General Management Plan: San Francisco Maritime National Historical Park.” San Francisco County, California: National Park Service.

- 2006a. Management Policies. Washington, D.C.: U.S. Government Printing Office.

. 2006b. "Environmental Assessment: Rehabilitate Failing Amphitheater Structure in Aquatic Park National Historic Landmark District.” San Francisco, California: National Park Service. San Francisco Maritime Research Library. 
2009. "San Francisco Maritime National Historical Park Action Plan." Climate Friendly Parks. National Park Service.

_. 2010. "Climate Change Response Strategy."

http://www.nature.nps.gov/climatechange/docs/NPS_CCRS.pdf.

. 2012. “Climate Change Action Plan 2012-2014." Fort Collins, Colorado:

National Park Service.

http://www.nps.gov/orgs/ccrp/upload/NPS_CCActionPlan.pdf.

2013. "Cultural Resource Challenge: Preserving America's Shared Heritage in the 21st Century." Fort Collins, Colorado: National Park Service. http://www.nps.gov/history/cultural-resource-challenge-report-part-i-nov-82013.pdf.

. 2014a. "A New Vision for a Great Urban National Park: Gateway National

Recreation Area Final General Management Plan Environmental Impact

Statement."

. 2014b. "Gulf Islands National Seashore Final General Management

Plan/Environmental Impact Statement.” General Management

Plan/Environmental Impact Statement. National Park Service.

2015a. "Panama-Pacific International Exposition, 1915: The World Meets in San Francisco." National Park Service.

https://www.nps.gov/goga/learn/historyculture/upload/PPIE-Brochure-FINALfor-Web.pdf.

. 2015b. "Yorktown Victory Monument." Yorktown Battlefield, Part of Colonial National Historical Park. August 21, 2015.

https://www.nps.gov/york/learn/historyculture/vicmon.htm.

.2015c. "Cultural Resources Adaptation.” December 26, 2015.

http://www.nps.gov/subjects/climatechange/adaptationforculturalresources.htm.

_ 2018. "Sea Level Change." National Park Service: Climate Change. January 3, 2018. https://www.nps.gov/subjects/climatechange/sealevelchange.htm.

Okamoto, Ariel Rubissow, and Kathleen M. Wong. 2011. Natural History of San Francisco Bay. California Natural History Guides. Berkeley, California: University of California Press.

Orlove, Ben. 2005. "Human Adaptation to Climate Change: A Review of Three Historical Cases and Some General Perspectives." Environmental Science and Policy 8: 589-600.

Otvos, Ervin G. 2005. "Coastal Barriers, Gulf of Mexico: Holocene Evolution and Chronology.” Journal of Coastal Research 42 (Special Issue): 141-63.

Otvos, Ervin G., and Marco J. Giardino. 2004. "Interlinked Barrier Chain and Delta Lobe Development, Northern Gulf of Mexico.” Sedimentary Geology 169 (1-2): 4773. 
Pacheco. 1880. Pueblo of San Francisco. Washington, D.C.

Paige, John C. 1985. "The Civilian Conservation Corps and the National Park Service, 1933-1942." Washington, D.C.: National Park Service.

Palsson, Gisli, Bronislaw Szerszynski, Sverker Sorlin, John Marks, Bernard Avril, Carole Crumley, Heide Hackmann, et al. 2013. "Reconceptualizing the 'Anthropos' in the Anthropocene: Integrating the Social Sciences and Humanities in Global Environmental Change Research." Environmental Science and Policy 28: 3-13.

Papers Relative to the Completion of the Monument of Yorktown. 1885. Washington, D.C.

Peacock, Walter Gillis, Samuel David Brody, and Wes Highfield. 2005. "Hurricane Risk Perceptions Among Florida's Single Family Homeowners." Landscape and Urban Planning 73 (2): 120-35.

Peek, Katie McDowell, Robert S. Young, Rebecca L. Beavers, Cat Hawkins Hoffman, Brian T. Diethorn, and Shawn Norton. 2015. "Adapting to Climate Change in Coastal Parks: Estimating the Exposure of Park Assets to $1 \mathrm{~m}$ of Sea-Level Rise." NPS/NRSS/GRD/NRR. Fort Collins, Colorado: National Park Service.

"Pensacola Is Going Places." 1948. Nautical Gazette 142 (6): 20-26.

Perkins. 1906. Light-House, Etc. Red Rock, San Francisco Bay, California. Washington, D.C.

Peterson, Charles E. 1931a. "Petersen to Whitehead." Record Group 79 Records of the National Park Service, Classified Files, 1927-1931, Box 53. National Archives, College Park, Maryland.

—. 1931b. "Memorandum to the Director: Choosing a Date for Jamestown and Other Recommendations." Record Group 79 Records of the National Park Service, Classified Files, 1927-1931, Box 53. National Archives, College Park, Maryland.

1931c. "Memorandum to Mr. Taylor: Proposed Changes in the Moore House." Record Group 79 Records of the National Park Service, Classified Files, 19271931, Box 53. National Archives, College Park, Maryland.

. 1931d. "Memorandum for the Director: Gasoline Stations on the Parkway." Record Group 79 Records of the National Park Service, Classified Files, 19271931, Box 53. National Archives, College Park, Maryland.

—. 1931e. "Peterson to the Director." Record Group 79 Records of the National Park Service, Classified Files, 1927-1931, Box 53. National Archives, College Park, Maryland.

. 1931f. "Peterson to Spelman." Record Group 79 Records of the National Park Service, Classified Files, 1927-1931, Box 53. National Archives, College Park, Maryland. 
1931g. "Peterson to Shurcliff." Record Group 79 Records of the National Park Service, Classified Files, 1927-1931, Box 53. National Archives, College Park, Maryland.

1931h. "Peterson to Smith." Record Group 79 Records of the National Park Service, Classified Files, 1927-1931, Box 53. National Archives, College Park, Maryland.

. 1931i. "Peterson to Robinson." Record Group 79 Records of the National Park Service, Classified Files, 1927-1931, Box 53. National Archives, College Park, Maryland.

Peterson, Nicole, and Kenneth Broad. 2009. "Climate and Weather Discourse in Anthropology: From Determinism to Uncertain Futures." In Anthropology and Climate Change: From Encounters to Actions, 70-86. Walnut Creek, California: Left Coast Press, Inc.

Pindell, James L. 1985. "Alleghenian Reconstruction and Subsequent Evolution of the Gulf of Mexico, Bahamas, and Proto-Caribbean.” Tectonics 4 (1): 1-39.

"Preserving the Design for Americans." N.D. Colonial Williamsburg. Box 5, Folder 4, William Pierce Kennedy Papers. Library of Virginia.

Pridemore, F.D. 1983. “Annual Narrative Report for Gulf Islands National Seashore.” Record Group 79 Records of the National Park Service, Superintendent's Annual Narrative Reports, 1980-2001, Box 28. National Archives, College Park, Maryland.

—. 1984. “Annual Narrative Report for Gulf Islands National Seashore.” Record Group 79 Records of the National Park Service, Superintendent's Annual Narrative Reports, 1980-2001, Box 28. National Archives, College Park, Maryland.

"Proposed Golden Gate National Recreation Area: Draft Environmental Impact Statement." 1971. Record Group 48 Records of the Office of the Secretary of the Interior, Central Classified Files, 1969-1972, Box 182. National Archives, College Park, Maryland.

Protecting America's Estuaries: The San Francisco Bay and Delta. 1970. Washington, D.C.

"Purpose of the National Seashore." 1973. Department of Interior, National Park Service. Record Group 79, Division of Interpretive Planning, Records of Public Input Documenting Interpretive Planning Activities, 1955-1999, Box 137. National Archives, College Park, Maryland.

Raupp, Jason T. 2007. "Fish On: Pensacola's Red Snapper Fishery.” The Florida Historical Quarterly 85 (3): 324-41.

Rawson, Michael. 2009. "What Lies Beneath: Science, Nature, and the Making of Boston Harbor." Journal of Urban History 35 (5): 675-97. 
Raymond, Christopher, and Gregory Brown. 2011. “Assessing Spatial Associations Between Perceptions of Landscape Value and Climate Change Risk for Use in Climate Change Planning." Climatic Change 104 (3-4): 653-78.

"Relacion De Teperamento 1785." 1785. Carton 21, Folder 18, San Francisco, Bancroft Reference Notes for California, [ca. 1870-1890]. Bancroft Library, University of California, Berkeley, California.

"Release for Morning Papers of October 12, 1931." 1931. National Press. Record Group 79 Records of the National Park Service, Classified Files, 1927-1931, Box 53. National Archives, College Park, Maryland.

Report of the Chief Engineer to the Secretary of War. 1848. Washington, D.C.: Wendell and van Benthuysen Printers.

"Report of the Secretary of the Navy: Plans and Estimates for the Construction of a Permanent Wharf and a Dry Dock at Pensacola." 1844.

Ricci, G., D. Robadue, Jr., P. Rubinoff, A. Casey, and A.L. Babson. 2018. “Colonial National Historical Park Integrated Coastal Climate Change Vulnerability Assessment: A Pilot Method." Natural Resource Report NPS/NER/NRR-2018/XXX. Fort Collins, Colorado: National Park Service.

Richards, Thomas J., and Lyn Richards. 1994. "Using Computers in Quatlitative Research." In Handbook of Qualitative Research, 445-62. Thousand Oaks, California: Sage Publications.

Richmond Times-Dispatch. N.D. “The Lee Family Remembers," N.D. Box 99, Folder 1, Virginia Department of Conservation \& Recreation, Division of History. Library of Virginia.

Riley, Edward M. 1952. "Suburban Development of Yorktown, Virginia, during the Colonial Period." The Virginia Magazine of History and Biography 60 (4): 522 36.

Rippon, Stephen. 2000. The Transformation of Coastal Wetlands: Exploitation and Management of Marshland Landscapes in North West Europe during the Roman and Medieval Periods. Oxford: Oxford University Press.

Robinson. 1935. Colonial National Monument in the State of Virginia. Washington, D.C.

Robinson, Jr., William M., Elbert Cox, and B. Floyd Flickinger. 1932. "Historical Notes, Volume I, No. 1.” Record Group 79, Nature Notes, 1927-1935, Box 2. National Archives, College Park, Maryland.

Rochefort, David A., and Roger W. Cobb. 1993. "Problem Definition, Agenda Access, and Policy Choice." Policy Studies 21 (1): 56-71.

Rockman, Marcy. 2003. "Knowledge and Learning in the Archaeology of Colonization." In Colonization of Unfamiliar Landscapes: The Archaeology of Adaptation, 3-24. London: Routledge. 
Rockman, Marcy, Marissa Morgan, Sonya Ziaja, George Hambrecht, and Alison Meadow. 2016. "Cultural Resources Climate Change Strategy." Washington, D.C.: Cultural Resources, Partnerships, and Science and Climate Change Response Program, National Park Service.

Rohland, Eleanora. 2015. "Hurricanes in New Orleans: Disaster Migration and Adaptation, 1718-1794." In Cultural Dynamics of Climate Change and the Environment in Northern America, 137-58. Boston, Massachusetts: Brill.

_ 2017. "Adapting to Hurricanes: A Historical Perspective on New Orleans from Its Foundation to Hurricane Katrina, 1718-2005.” WIREs Climate Change, September. https://doi.org/10.1002/wcc.488.

Romans, Bernard. 1962. A Concise Natural History of East and West Florida; A Facsimile Reproduction of the 1775 Edition with Introduction by Rembert W. Patrick. Floridiana Facsimilie \& Reprint Series. Gainsville, Florida: University Press of Florida.

Roncoli, Carla, Todd Crane, and Ben Orlove. 2009. "Fielding Climate Change in Cultural Anthropology.” In Anthropology and Climate Change: From Encounters to Actions, 97-115. Walnut Creek, California: Left Coast Press, Inc.

"S Fco Was Not Changed..." 1823. Carton 16, Folder 18, San Francisco, Bancroft Reference Notes for California, [ca. 1870-1890]. Bancroft Library, University of California, Berkeley, California.

Sabbioni, Cristina, and Alessandra Bonazza. 2009. "How Mapping Climate Change for Cultural Heritage? The Noah's Ark Project." In Climate Change and Cultural Heritage, 37-41. Bari, Italy: Edipuglia.

Sabbioni, Cristina, Peter Brimblecombe, and May Cassar, eds. 2010. The Atlas of Climate Change Impacts on European Cultural Heritage: Scientific Analysis and Management Strategies. New York City, New York: Anthem Press.

Sabbioni, Cristina, May Cassar, Peter Brimblecombe, and Roger-Alexandre Lefevre. 2008. "Vulnerability of Cultural Heritage to Climate Change." European and Mediterranean Major Hazards Agreement. Strasbourg, France: Council of Europe.

San Francisco Chronicle. 1877. "Ante-Pioneer Days: A Few Relics of Mexican Occupancy of California," November 6, 1877. Carton 17, Folder 1, San Francisco, Bancroft Reference Notes for California, [ca. 1870-1890]. Bancroft Library, University of California, Berkeley, California.

San Francisco Post. 1876. "How the Bay City Was Founded One Hundred Years Ago," May 20, 1876. Carton 16, Folder 11 San Francisco, Bancroft Reference Notes for California, [ca. 1870-1890]. Bancroft Library, University of California, Berkeley, California.

Schreck III, C.J., K.R. Knapp, and J.P. Kossin. 2014. "The Impact of Best Track Discrepancies on Global Tropical Cyclone Climatologies Using IBTrACS.” 
Monthly Weather Review 142: 3881-99. https://doi.org/10.1175/MWR-D-1400021.1 .

Schroter, Dagmar, Colin Polsky, and Anthony G. Patt. 2005. "Assessing Vulnerabilities to the Effects of Global Change: An Eight Step Approach." Mitigation and Adaptation Strategies for Global Change 10: 573-96.

Schupp, Courtney A., Rebecca L. Beavers, and Maria A. Caffrey. 2015. "Coastal Adaptation Strategies: Case Studies.” NPS 999/129700. Fort Collins, Colorado: National Park Service.

Schwartz, Stuart B. 2015. Sea of Storms: A History of Hurricanes in the Greater Caribbean from Columbus to Katrina. Princeton, New Jersey: Princeton University Press.

Scott, James C. 1998. Seeing Like a State: How Certain Schemes to Improve the Human Condition Have Failed. New Haven, Connecticut: Yale University Press.

Scott, Mel. 1985. The San Francisco Bay Area: A Metropolis in Perspective. 2nd ed. Berkeley, California: University of California Press.

Sears, Stephen W. 1992. To the Gates of Richmond: The Peninsula Campaign. New York City, New York: Ticknor \& Fields.

Secretary of the Army. 1964. Middle and Lower Peninsulas of Virginia. Washington, D.C.

1966. Hurricane Survey of the Northwest Florida Coast. Washington, D.C.

Secretary of the Interior. 1969. "This Letter Is in Reply...” Record Group 79 Records of the National Park Service, Administrative Files, 1949-1971, Box 1998. National Archives, College Park, Maryland.

Secretary of the Navy. 1829. "Annual Report Showing the Condition of the Navy in the Year 1829." U.S. Secretary of the Navy. University of West Florida Archive and West Florida History Center.

- 1852. Report of the Secretary of the Navy. Washington, D.C.

- 1889. Report of Navy-Yard Site Commission, Gulf of Mexico and South Atlantic Coasts. Washington, D.C.

Secretary of the Treasury. 1906a. Additional Appropriation for Piers, Hampton Roads, Jamestown Exposition. Washington, D.C.

- 1906b. Transportation of Troops, Jamestown Exposition. Washington, D.C.

—. 1907. "Seawalls at Pensacola Harbor, Florida." Individual Files. University of West Florida Archive and West Florida History Center.

Secretary of War. 1837. Survey of the James River. Washington, D.C. 1854. Fortifications at Fort Point and Alcatrazas Island. Washington, D.C. 
- 1871. Engineer's Report of Certain Rivers and Harbors. Washington, D.C. . 1880. Copy of Report of Capt. C.B. Phillips, Corps of Engineers, of Surveys of York River, and of Lynn Haven, Link Horn, and Broad Bays, Virginia. Washington, D.C.

- 1882. Survey of the James River, VA. Washington, D.C.

. 1886. Provision for Quarters for Keeper of Yorktown Monument. Washington, D.C.

. 1897. Survey of Shag Rocks and Other Rocks, San Francisco Harbor, California. Washington, D.C.

Seemann, Berthold. 1846. "Seemann's Voyage of the Herald, Volume 1." Carton 17, Folder 5, San Francisco, Bancroft Reference Notes for California, [ca. 18701890]. Bancroft Library, University of California, Berkeley, California.

Sewell, Jr., William H. 1992. “A Theory of Structure: Duality, Agency, and Transformation.” American Journal of Sociology 98 (1): 1-29.

Shallat, Todd. 1989. "Engineering Policy: The U.S. Army Corps of Engineers and the Historical Foundation of Power." The Public Historian 11 (3): 6-27. https://doi.org/10.2307/3378610.

Sheridan, Rae, and John Sheridan. 2013. International Heritage Instruments and Climate Change. Champaign, Illinois: Common Ground Publishing, LLC.

Sherman, W.T. 1847. "Headquarters Tenth Military Department." Carton 5, Folder 5 Land: San Francisco, Bancroft Reference Notes for California, [ca. 1870-1890]. Bancroft Library, University of California, Berkeley, California.

Smith, Bertrand E. 1935. "Smith to the Chief of the Bureau of Biological Survey." Record Group 79 Records of the National Park Service, Records of the Washington Office of the Wildlife Division, 1934-1936, Box 2. National Archives, College Park, Maryland.

Smith, H. Reese. 1968. "Review of Proposed Master Plan, Gulf Islands." Record Group 79 Records of the National Park Service, General Correspondence of the Asst. Director for Design and Construction, 1965-1968, Box 34. National Archives, College Park, Maryland.

Smith, Joel B., and William R. Travis. 2010. "Adaptations to Climate Change in Public Lands Management.” Resources for the Future Issue Brief 10 (4): 1-16.

Smith, John. 1624. "Virginia Discovered and Described by Captayn John Smith, 1606, Engraven by William Hole." Archives Research Services Map Collection, A5 Voorhees Collection, G3880. Library of Virginia.

Smith, Mark M. 2011. "The Sensory History of a Natural Disaster." In Camille, 1969: Histories of a Hurricane, 1-20. Atlanta, Georgia: University of Georgia Press. 
Smith, Mrs. Sydney. 1920. "Old Yorktown and Its History." Colonial Williamsburg. Box 5, Folder 4, William Pierce Kennedy Papers. Library of Virginia.

Smith, Ruth Ann, and David S. Lux. 1993. "Historical Method in Consumer Research: Developing Causal Explanations of Change." Journal of Consumer Research 19 (4): 595-610.

Smythe, W.H. n.d. "Address of Captain W.H. Smythe.” Journal of the London Geographical Society. Carton 2, Folder 22, Discovery and Exploration 16361843, Bancroft Reference Notes for California. Bancroft Library, University of California, Berkeley, California.

Soubier, L. Clifford. 1979. "Interpretive Prospectus: Gulf Islands National Seashore." Harpers Ferry, West Virginia: National Park Service.

Springston, Rex. 2013. "Jamestown Faces a Future of Rising Tides: As Sea Levels Rise Across the Globe, Virginia's Most Historic Island Could Be Flooded by 2100.” Richmond Times-Dispatch. March 10, 2013. http://www.richmond.com/news/virginia/jamestown-faces-a-future-of-risingtides/article_7c6e60c7-11fc-5bba-82a2-530f7c7b0385.html.

Stagner, Howard R. 1968. "Minutes of the 59th Meeting of the Advisory Board on National Parks, Historic Sites, Buildings, and Monuments.” Record Group 79 Records of the National Park Service, General Correspondence of the Asst Director for Design \& Construction, 1965-1968, Box 1. National Archives, College Park, Maryland.

Stanton, Frederick P. 1851. Steamers Between California and China. Washington, D.C.

Steenhagen, Robert L., Rock L. Comstock, Frank Ugolini, John E. Murphy, Pete Shedd, Nan V. Rickey, Larry Hadley, and James Corson. 1971. "A Master Plan for Colonial National Historical Park.” National Park Service. Record Group 79, Division of Interpretive Planning, Records of Public Input Documenting Interpretive Planning Activities, 1955-1999, Box 59. National Archives, College Park, Maryland.

Steinberg, Philip E. 2001. The Social Construction of the Ocean. Cambridge: Cambridge University Press.

Stern, Philip N. n.d. "Architectural Remains, Unit A, Sub-Unit 39, Jamestown Island, Virginia." Historic American Buildings Survey. Historic American Buildings Survey, Virginia, Volume 122. Library of Congress, Washington, D.C.

Stinson, Landon. 2016. "Future of Fort Pickens Up to Nature." Pensacola New Journal, January 3, 2016.

Stockbridge, Frank Parker, and John Holliday Perry. 1926. Florida in the Making. New York City, New York: The de Bower Publishing Co.

Storch, Hans von, and Nico Stehr. 2006. "Anthropogenic Climate Change: A Reason for Concern Since the 18th Century and Earlier." Geografiska Annaler, Physical Geography, 88 (2): 107-13. 
"Sub. Commisio to Gov." 1833. Carton 17, Folder 1, San Francisco, Bancroft Reference Notes for California, [ca. 1870-1890]. Bancroft Library, University of California, Berkeley, California.

Sullivan, James R. 1981. "Superintendent's Annual Report, Calendar Year 1980:

Colonial National Historical Park, Yorktown, Virginia through Reports 1984 in 1 Folder.” Record Group 79 Records of the National Park Service, Classified Files, 1927-1931, Box 53. National Archives, College Park, Maryland.

“Superintendent's Annual Report." 1951. Record Group 79, Records of the National Park Service, Administrative Files, 1949-1971, Box 108. National Archives, College Park, Maryland.

__. "Superintendent's Annual Report." 1953. Record Group 79, Records of the National Park Service, Administrative Files, 1949-1971, Box 108. National Archives, College Park, Maryland.

. "Superintendent's Annual Report." 1959. Record Group 79, Records of the National Park Service, Administrative Files, 1949-1971, Box 75. National Archives, College Park, Maryland.

Tarr, Joel A., and Charles Jacobson. 1987. "Environmental Risk in Historical Perspective." In The Social and Cultural Construction of Risk: Essays on Risk Selection and Perception, 317-44. Boston, Massachusetts: D. Reidel Publishing Company.

Taylor, A.S. 1856. "Influence of California Climate on Animal Life Pt. 1." San Francisco Bulletin, December 8, 1856. Carton 21, Folder 18, San Francisco, Bancroft Reference Notes for California, [ca. 1870-1890]. Bancroft Library, University of California, Berkeley, California.

Taylor, Bayard. 1870. "San Francisco Past and Present: The Changes of Twenty Years, Bayard Taylor's Third Visit." Carton 18, Folder 1, San Francisco, Bancroft Reference Notes for California, [ca. 1870-1890]. Bancroft Library, University of California, Berkeley, California.

Tengberg, Anna, Susanne Fredholm, Ingegard Eliasson, Igor Knez, Katarina Saltzman, and Ola Wetterberg. 2012. "Cultural Ecosystem Services Provided by Landscapes: Assessment of Heritage Values and Identity.” Ecosystem Services 2: $14-26$.

The Afro-American Bicentennial Corporation. 1973. "Beyond the Fireworks of 76."

The Board of Engineers for Rivers and Harbors. 1962. The Ports of San Francisco, Redwood City, California. Washington, D.C.: United States Government Printing Office.

The Chief of Engineers. 1936. "Channel From Pensacola Bay into Bayou Chico, Fla." Committee on Rivers and Harbors, House of Representatives, April 25, 1936. University of West Florida Archive and West Florida History Center. 
"The Great Dismal Swamp." 1907. Jamestown A\&V Co. Jamestown Tercentenary Exposition, Hampton Roads, Virginia. Library of Congress, Washington, D.C.

"The Narrator Landed at San Fco." 1849. Carton 17, Folder 8, San Francisco, Bancroft Reference Notes for California, [ca. 1870-1890]. Bancroft Library, University of California, Berkeley, California.

The Pensacola Journal. 1906. “\$300,000 Is the Estimated Damage,” October 5, 1906.

"There Used to Be In..." 1878. Carton 16, Folder 11 San Francisco, Bancroft Reference Notes for California, [ca. 1870-1890]. Bancroft Library, University of California, Berkeley, California.

Thompson, Laura M., Michelle D. Staudinger, and Shawn L. Carter. 2015. "Summarizing Components of U.S. Department of the Interior Vulnerability Assessments to Focus Climate Adaptation and Planning." 2015-1110. Reston, Virginia: U.S. Department of the Interior and U.S. Geological Survey.

Thompson, Victor D., and John E. Worth. 2011. "Dwellers by the Sea: Native American Adaptations Along the Southern Coasts of Eastern North America." Journal of Archaeological Research 19 (1): 51-101.

"Three Views of Ruins of Fort McRee, Florida." 1906. S.H. Kress and Company. Florida Memory Collection. State Archives of Florida. https://www.floridamemory.com/items/show/140418.

Toms, R.E. 1931. "Toms to Demaray." Record Group 79 Records of the National Park Service, Classified Files, 1927-1931, Box 53. National Archives, College Park, Maryland.

Toscano, Marguerite A. 2004. "Assessment of Vulnerability of Coastal Cultural and Archaeological Resources to Sea-Level Rise and Coastal Processes: Gulf Islands National Seashore Florida and Mississippi, Recommendations for Protection and Preservation.” 2003-GUIS. Geoscientists-in-the-Parks. Fort Collins, Colorado: National Park Service.

Toulmin, Stephen E. 2003. The Uses of Argument. New York City, New York: Cambridge University Press.

Towle, Jerry C. 2000. "Authored Ecosystems: Livingston Stone and the Transformation of California Fisheries." Environmental History 5 (1): 54-74.

Trinity Journal. 1864. "Don Salvio Pacheco an Old...," March 26, 1864. Carton 21, Folder 18, San Francisco, Bancroft Reference Notes for California, [ca. 18701890]. Bancroft Library, University of California, Berkeley, California.

Tunbridge, J.E., and G.J. Ashworth. 1996. Dissonant Heritage: The Management of the Past as a Resource in Conflict. Chichester, United Kingdom: John Wiley and Sons.

Udall. 1987. National Maritime Museum Act of 1987. Washington, D.C. 
Underwood, W.H. 1935. "Photograph No. 1 - March 1, 1935. Before Work Was Started. Station 285 Looking down River." Record Group 79 Records of the National Park Service, Narrative Reports Concerning CCC Projects in Nat'l Park Service Areas, 1933-1935, Box 31. National Archives, College Park, Maryland.

United States Congress. 1916. Organic Act. 16 U.S.C. 1. Vol. 39 Stat. 53.

U.S. Treasury Department. 1907. "Estimates of Quarantine Stations in Pensacola," January 5, 1907. Hurricane Damage at Pensacola, Florida. University of West Florida Archive and West Florida History Center.

Vaughan, Jr., H.B. 1931. "Vaughan, Jr. to Taylor." Record Group 79 Records of the National Park Service, Classified Files, 1927-1931, Box 53. National Archives, College Park, Maryland.

Vecco, Marilena. 2010. "A Definition of Cultural Heritage: From the Tangible to the Intangible." Journal of Cultural Heritage 11 (3): 321-24.

Vint, Thomas. 1931. "Memorandum for the Director Regarding the Development of Yorktown." Record Group 79 Records of the National Park Service, Classified Files, 1927-1931, Box 53. National Archives, College Park, Maryland.

Wadsworth. 1926. Study and Investigation of the Battle Fields in the United States for Commemorative Purposes.

Wagner. 1928. Recreation Pier at the Foot of Van Ness Avenue, San Francisco, California. Washington, D.C.

Wagoner, Luther, and W.H. Heuer. 1908. San Francisco Harbor: Its Commerce and Docks, with a Complete Plan for Development. Federated Harbor Improvement Associations.

Wakild, Emily. 2011. Revolutionary Parks: Conservation, Social Justice, and Mexico's National Parks, 1910-1940. Tuscon, Arizona: University of Arizona Press.

Waldstreicher, David. 1997. In the Midst of Perpetual Fetes: The Making of American Nationalism, 1776-1820. Chapel Hill, North Carolina: University of North Carolina Press for the Omohundro Institute of Early American Culture.

Walsh. 1941. Authorizing the Transfer of Jurisdiction of a Portion of the Colonial National Historical Park, Yorktown, VA from the Department of the Interior to the Department of the Navy. Washington, D.C.

Ward, Peter L., and Robert A. Page. 1980. "The Loma Prieta Earthquake of October 17, 1989.” U.S. Geological Survey. https://pubs.usgs.gov/unnumbered/70039527/report.pdf.

Watkins, T.H., and R.R. Olmsted. 1976. Mirror of the Dream: An Illustrated Hisotry of San Francisco. Oakland, California: Scrimshaw Press. 
Weaver II, John R. 2001. A Legacy in Brick and Stone: Coastal Defense Forts of the Third System, 1816-1867. Missoula, Montana: Pictorial Histories Publishing Company.

Webb, Melody. 1987. "Cultural Landscapes in the National Park Service." The Public Historian 9 (2): 77-89.

Weddle, Robert S. 1985. Spanish Sea: The Gulf of Mexico in North American Discovery, 1500-1685. College Station, Texas: Texas A\&M University Press.

Weiss, Jacob. 1869. "A Correct Map of Pensacola Bay Showing Topography of the Coast, Fort Pickens, U.S. Navy Yard, and All Other Fortifications from the Latest Government Surveys.” Philadelphia, Pennsylvania: Weiss. Norman B. Leventhal Map Center. Boston Public Library. https://www.digitalcommonwealth.org/search/commonwealth:kk91ft02k.

Westerdahl, Christer. 1992. "The Maritime Cultural Landscape.” The International Journal of Nautical Archaeology 11 (3): 5-14.

WHC. 2006. "Predicting and Managing the Effects of Climate Change on World Heritage: A Joint Report from the World Heritage Centre, Its Advisory Bodies, and a Broad Group of Experts to the 30th Session of the World Heritage Committee." Vilnius, Lithuania: United Nations Educational, Scientific, and Cultural Organization. http://whc.unesco.org/en/climatechange/.

White, Joseph M. 1836. "Speech of Mr. White, of Florida on the Naval Appropriations for Pensacola Delivered in the House of Representatives, April 6, 1836." U.S. Secretary of the Navy. University of West Florida Archive and West Florida History Center.

Whitney, Gordon G. 1996. From Coastal Wilderness to Fruited Plain: A History of Environmental Change in Temperate North Americna from 1500 to the Present. New York City, New York: Cambridge University Press.

Wigley, T.M.L., M.J. Ingram, and G. Farmer, eds. 1981. Climate and History: Studies in Past Climate and Their Impact on Man. Cambridge: Cambridge University Press.

Winegar, Paul. 1977. "Park Service Plans to Dredge Davis Bayou Entrance Channel." Gulf Islands National Seashore Papers Box 4, Folder 3. University of West Florida Archive and West Florida History Center.

Wirth, Conrad L. 1955. "Wirth to McMurran.” Record Group 79 Records of the National Park Service, Administrative Files, 1949-1971, Box 1459. National Archives, College Park, Maryland.

Wise. 1834. Monument at York, in Virginia. Washington, D.C. 1894. Port Lights on York River, Virginia. Washington, D.C.

Wise, Henry Augustus. 1849. Los Gringos, or, An inside View of Mexico and California, with Wanderings in Peru, Chili, and Polynesia. New York City, New York: Baker and Scribner. 
Wong, Poh Poh, Inigo J. Losada, Jean-Pierre Gattuso, Jochen Hinkel, Abdellatif Khattabi, Kathleen L. McInnes, Yoshiki Saito, and Asbury Sallenger. 2014. "Coastal Systems and Low-Lying Areas." In Climate Change 2014: Impacts, Adaptation and Vulnerability, Part A: Global and Sectoral Aspects. Contribution of Working Group II to the Fifth Assessment Report of the Intergovernmental Panel on Climate Change, 361-409. Cambridge, United Kingdom: Cambridge University Press.

Worrall, D.M., and S. Snelson. 1989. "Evolution of the Northern Gulf of Mexico, with Emphasis on Cenozoic Growth Faulting and the Role of Salt." In Geology of North America: An Overview, A:97-138. The Decade of North American Geology Project Series. Boulder, Colorado: The Geological Society of America.

Yin, Robert K. 2003. Case Study Research: Design and Methods. 3rd ed. Thousand Oaks, California: Sage Publications.

Young, Terence. 2004. Building San Francisco's Parks, 1850-1930. Creating the North American Landscape. Baltimore, Maryland: The Johns Hopkins University Press. 